Col·lecció Humanitats
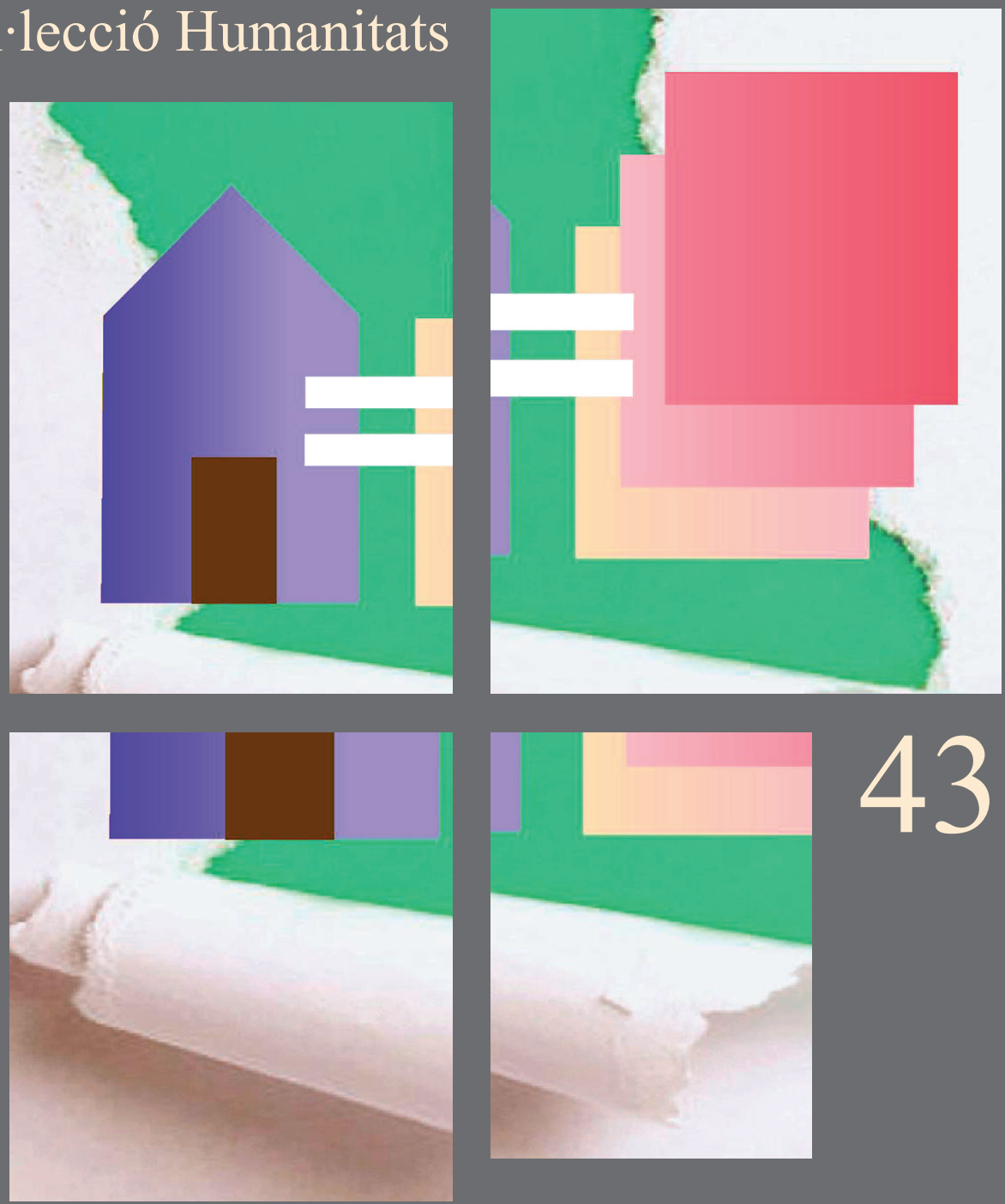

LA CONCILIACIÓ DE LA VIDA LABORAL I FAMILIAR A LA UNIVERSITAT JAUME I

Mercedes Alcañiz Moscardó (ed.)

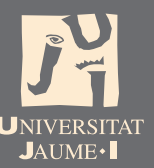


La conciliació entre la vida laboral i la familiar es va incloure en l'agenda política a la fi de la dècada dels anys noranta del segle passat i ha esdevingut un tema mediàtic i quotidià que afecta especialment a les persones que tenen criatures o majors dependents, i per això han de compaginar el temps laboral i el que dediquen a la cura i atenció d'aquestes persones i a les tasques domèstiques. Aquesta publicació conté els resultats de la implementació de les Accions 64 i 65 incloses en l'I Pla d'Igualtat de la Universitat Jaume I (2010-2014) relacionades amb l'elaboració d'una enquesta entre el PAS i el PDI de la nostra Universitat per a conéixer les necessitats que tenen al voltant de la conciliació de la vida laboral i familiar amb la finalitat de millorar la qualitat de vida dels treballadors i les treballadores.

Mercedes Alcañiz és professora titular de Sociologia i directora de la Unitat d'Igualtat de la Universitat Jaume I des de febrer de 2013. Ha coordinat aquesta publicació en la qual participen la Unitat d'Igualtat, la Fundació Isonomía, l'Institut d'Estudis Feministes Purificación Escribano, així com membres de grups d'investigació especialitzats en estudis de gènere de la nostra Universitat. 
Col·lecció «Humanitats»

Núm. 43

\section{LA CONCILIACIÓ DE LA VIDA LABORAL I FAMILIAR A LA UNIVERSITAT JAUME I}

Mercedes AlCañız Moscardó (ed.)

Hedy Acosta Antognoni amparo Campos Suliano

Gemma Escrig GIL Santiago García Campá Ana Martí Gual María José Ortí Porcar Lourdes Pascual Gargallo Vicent Querol Vicente Anna Sales Boix

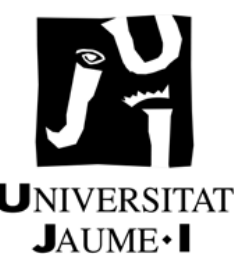




\section{BIBLIOTECA DE LA UNIVERSITAT JAUME I. Dades catalogràfiques}

La Conciliació de la vida laboral i familiar a la Universitat Jaume I / Mercedes Alcañiz (editora) ; Hedy Acosta Antognoni ... [et al.] — Castelló de la Plana : Publicacions de la Universitat Jaume I, D.L. 2014

p.; cm. - (Humanitats ; 43)

Bibliografia.

ISBN 978-84-697-1368-6

1. Conciliació de la vida personal i laboral. 2. Universitat Jaume I - Personal Relacions familiars. I. Alcañiz Moscardó, Mercedes, ed. II. Acosta Antognoni, Hedy. III. Universitat Jaume I. Publicacions. IV. Sèrie : Humanitats (Universitat Jaume I) ; 43

$331: 392.3$

378(460.311 C.).08:392.3

JHBL

JHBK

JNMN

Qualsevol forma de reproducció, distribució, comunicació pública o transformació d'aquesta obra només pot ser realitzada amb l'autorització dels seus titulars, llevat d'excepció prevista per la llei. Dirigiu-vos a CEDRo (Centro Español de Derechos Reprográficos, www.cedro.org) si necessiteu fotocopiar o escanejar fragments d'aquesta obra.

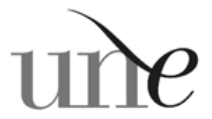

Unión de EdTTORIALES UnIVERSITARIAS EspaÑolas
Publicacions de la Universitat Jaume I és una editorial membre de l'une, cosa que garanteix la difusió i comercialització de les seues obres en els àmbits nacional i internacional. www.une.es.

Aquest text està subjecte a una llicència Reconeixement-CompartirIgual de Creative Commons, que permet copiar, distribuir i comunicar públicament l'obra sempre que s'especifique l'autor i el nom de la publicació fins i tot amb objectius comercials i també permet crear obres derivades, sempre que siguen distribuïdes amb aquesta mateixa llicència. http://creativecommons.org/licenses/by-sa/3.0/legalcode

Edita: Publicacions de la Universitat Jaume I. Servei de Comunicació i Publicacions Campus del Riu Sec. Edifici Rectorat i Serveis Centrals

12071 Castelló de la Plana

Fax: 964728832

http://www.tenda.uji.es e-mail: publicacions@uji.es

ISBN: 978-84-697-1368-6

DOI: http://dx.doi.org/10.6035/Humanitats.2014.43

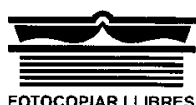

NO ÉS LEGAL 


\section{ÍNDEX}

Pròleg, Vicent Climent, rector

\section{Agraïments}

\section{Introducció}

Capítol I. La conciliació de la vida laboral i la vida familiar: contextualització teòrica $i$ analítica

1. La construcció social dels gèneres: de la separació a la conciliació de rols i espais.- 1.1. El patriarcat: divisió de rols i d'espais.- 1.2. Modificacions en el sistema patriarcal: la incorporació de les dones al mercat laboral.1.3. La conciliació de la vida laboral i familiar: una proposta de canvi per als homes i les dones, o només per a les dones?-2. Estratègies i pràctiques per a la conciliació entre la vida laboral i la vida familiar.- 2.1. Estratègies relacionades amb les normatives estatals: la conciliació pública.- 2.2. Estratègies i pràctiques relacionades amb les mesures reguladores laborals.- 2.3. Estratègies privades: la substitució del treball domèstic i d'atenció.- 3. La incorporació de la conciliació en l'agenda política internacional 
Capítol II. La regulació dels drets de conciliació a la Universitat Jaume I

1. Introducció.- 2. La regulació legal dels drets de conciliació de la vida personal, familiar i laboral.- 2.1. Permís per a la realització d'exàmens prenatals i tècniques de preparació al part.- 2.2. Permís per part o maternitat.2.3. Permís per adopció o acolliment.- 2.4. Permís per paternitat.- 2.5. Permís en cas de fills i filles prematurs o hospitalitzats a continuació del part.- 2.6. Permís per lactància: acumulació d'hores de lactància.- 2.7. Reducció de la jornada de treball per guarda legal.- 2.8. Permís per accident o malaltia greu de familiars fins al segon grau de consanguinitat o afinitat.- 2.9. Reducció per atenció a familiar de primer grau per malaltia molt greu.2.10. Reducció per atenció a menor afectat per càncer 0 una altra malaltia greu.- 2.11. Excedència per atenció a fills i filles o familiars a càrrec seu.- 2.12. Adaptació de la jornada de treball.- 3 . Altres mesures de conciliació.3.1. Flexibilitat de la permanència obligatòria.- 3.2. Permís per a visites mèdiques i assistència a persones menors, ancianes i amb discapacitat.- 3.3. Reducció de jornada per raó de malaltia llarga o crònica.- 3.4. Llicència per malaltia de familiars.- 3.5. Preferència en l'elecció d'horaris o en l'assistència a cursos de formació (I Pla d'Igualtat de l'UuI).- 4. Els drets de conciliació de les víctimes de violència de gènere.- 5 . Algunes reflexions finals 
Capítol III. Característiques sociodemogràfiques del personal treballador de la Universitat Jaume I

1. El personal d'administració i serveis (PAS).- 1.1. El PAS segons sexe i relació jurídica amb l'UJI.- 1.2. Classificació professional del PAS per sexe.- 1.3. Distribució del PAS en l'estructura organitzativa de l'UJI.- 1.4. El pas per grups d'edat i sexe.- 2. El personal docent $\mathrm{i}$ investigador de la Universitat (PDI).- 2.1. Distribució del PDI per centres i sexe.- 2.2. Categories professionals del PDI per sexe.- 2.3. El PDI per grups d'edat i sexe.- 2.4. Distribució del PDI segons òrgans de direcció el 2013

Capítulo IV. La conciliació de la vida laboral i familiar a la Universitat Jaume I

1. Normativa i mesures en matèria de conciliació: coneixement $i$ ús a la Universitat Jaume I.- 1.1. El personal d'administració i serveis (PAS).- 1.2. El personal docent $\mathrm{i}$ investigador (PDI).- 1.3. Similituds i diferències en els resultats del PAS i del PDI.- 1.4. Conclusions.- 2. La distribució de les tasques domèstiques i d'atenció en els treballadors i treballadores de la Universitat Jaume I.- 2.1. Descriptius generals.- 2.2. Resultats sobre les responsabilitats domèstiques del PAS i del PDI.- 3. Percepció d'equilibri en el repartiment de les tasques domèstiques i d'atenció.- 3.1. En el repartiment de tasques domèstiques.- 3.2. En l'atenció a fills i filles.- 3.3. Entre les necessitats personals, familiars i laborals.- 3.4. Conclusions.- 4. Complicació per a conciliar la vida laboral i la vida familiar en el personal de l'uлা.- 4.1. Complicació per a conciliar segons categoria laboral.- 4.2. Complicació segons l'edat.- 4.3. Complicació segons el nombre de fills i filles.- 4.4. Conclusions 
Conclusions i recomanacions

Bibliografia

Autores i autors de la publicació

Fitxa tècnica

Qüestionaris 


\section{PRÒLEG}

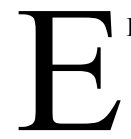

LS DEBATS SOBRE LA CONCILIACIÓ de la vida laboral i familiar i sobre la igualtat entre dones i homes, els discursos dels quals s'interrelacionen molt sovint, porten dècades en mans de l'opinió pública del nostre entorn, guanyant o perdent interès segons circumstàncies diverses, algunes sobrevingudes i altres intencionadament provocades per grups socials concrets. Però aquests debats, que solen trobar el seu espai per excel·lència en els escenaris mediàtics, a penes aconsegueixen la profunditat que seria desitjable perquè la ciutadania puga formar-se un judici prou crític que permeta afrontar amb garanties decisions sovint complexes i molt importants.

Les universitats públiques, en compliment de la seua missió, amb els seus mètodes $i$ els seus temps, afronten les grans qüestions socials aprofundint àmpliament en el coneixement dels fets, les idees i les opinions, en les seues causes i en les seues previsibles conseqüències. A través de la investigació, l'anàlisi interdisciplinària, el debat plural i la divulgació, la Universitat proveeix la societat d'informació de molta importància, proposa polítiques i pautes d'actuació que, en la majoria de les ocasions, posa en pràctica la mateixa institució per coherència ètica i amb la voluntat deliberada de demostrar-ne la viabilitat i actuar així com a prescriptora social.

La Universitat Jaume I, sobre la base dels seus principis rectors, ha manifestat des del primer moment de la seua creació un compromís especial amb la igualtat. Es tracta d'un compromís que durant aquests quasi 25 anys d'història s'ha materialitzat tant en la investigació i la transmissió de coneixements com en l'adopció de polítiques institucionals i la promoció de bones pràctiques en el si de la comunitat 
universitària i també de canvis culturals en el nostre entorn social més pròxim.

Aquesta publicació és el resultat de l'aplicació efectiva que s'ha dut a terme fins avui del I Pla d'Igualtat de la Universitat Jaume I, aprovat a l'abril de $2010 \mathrm{amb}$ la finalitat de fer explícites i efectives tota una sèrie de mesures orientades a avançar en la conquesta d'una igualtat real de tracte i d'oportunitats entre les persones que integren la comunitat universitària. En aquest procés, la conciliació de la vida laboral i familiar ocupa una posició significativa i el coneixement i l'anàlisi de les necessitats del personal universitari, així com dels seus frens i motivacions en l'ús de les mesures de conciliació aprovades per la Universitat és indispensable per a avançar, en aquest àmbit, amb vista a la confecció imminent del II Pla d'Igualtat. Així mateix, el contingut d'aquest llibre ens permet obtenir una espècie de fotografia de la situació actual en matèria de conciliació i d'altres importants qüestions inherents a aquesta, com ara l'exercici de la coresponsabilitat en la parella o l'exercici dels rols de gènere entre els seus membres.

El present treball constitueix una informació de gran utilitat, en gran manera extrapolable a la cultura social del nostre entorn, que estic segur que acabarà generant nou coneixement sobre una qüestió que a la Universitat Jaume I ens ocupa i preocupa des de fa anys i continua tenint un protagonisme estratègic en la nostra agenda política, científica, docent i cultural, segurs com estem de la necessitat de continuar fent contribucions amb valor específic a un procés de canvi que, avançant amb més o menys agilitat en uns moments o altres de la nostra història, és realment imparable. Per això, pel que fa a aquest repte humà que és la plena igualtat, amb el qual estem tan compromesos, des de la Universitat Jaume I continuarem posant la nostra confiança en la saviesa com a clau dels assoliments orientats a fer-nos més lliures.

Vicent Climent Rector de la Universitat Jaume I 


\section{AGRAÏMENTS}

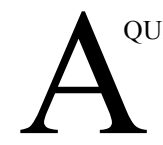

QUESTA PUBLICACIÓ HA ESTAT POSSIBLE gràcies a l'ajuda concedida el 2012 per l'Institut de la Dona del Ministeri de Sanitat, vencions concedides a la realització de postgraus oficials d'igualtat entre dones i homes, accions complementàries a la investigació i activitats de les unitats d'igualtat de les universitats (PACUI).

En concret, 1'ajuda rebuda per la Unitat d'Igualtat de la Universitat Jaume I (UJ) es vincula a les accions 64 i 65 del I Pla d'Igualtat (2010-2014), incloses en 1'Àrea 3. «Enfortiment de les possibilitats de conciliació de la vida personal, familiar i laboral des de la coresponsabilitat d'homes i dones»».

En el context d'aquesta ajuda vam decidir realitzar una enquesta al personal de l'Uur amb l'objectiu de conèixer les seues necessitats de conciliació.

Les autores i els autors d'aquest llibre volem expressar el nostre reconeixement a Amparo Garrigues, professora titular de Dret del Treball, i anterior directora de la Unitat d'Igualtat de l'usI, que va ser qui va sol-licitar aquesta ajuda.

Així mateix, agraïm a l'Oficina de la Promoció i Avaluació de la Qualitat (OPAQ), especialment a la seua directora M. José Oltra i a Teresa Mora per la seua ajuda en la realització de l'enquesta en línia; a Carme Pinyana, editora del Servei de Publicacions, pel suport rebut perquè la publicació fóra possible; a Vicente Sales, cap del Servei de Recursos Humans, per facilitar-nos informació actualitzada sobre el personal de 1'usi; a Aurelia Bengochea, vicerectora d'Estudis i Espai Europeu d'Educació Superior, pel seu suport en la realització d'aquesta publicació; a Santiago García per la revisió minuciosa dels 
continguts que presentem; a M. Jesús Sales, administrativa de la Unitat d'Igualtat, per la gestió i organització del text i, finalment, al Servei de Llengües per la rigorosa traducció de la present publicació.

Per descomptat, manifestem una gratitud especial al personal docent $\mathrm{i}$ investigador i al personal d'administració i serveis de l'uJ que amablement va contestar el qüestionari.

Finalment, volem mostrar el nostre agraïment a la Universitat Jaume I per l'interès manifestat des de la seua creació per l'objectiu d'aconseguir la igualtat entre dones i homes. 


\section{INTRODUCCIÓ}

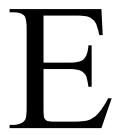

1 I Pla D'Igualtat de la Universitat Jaume I es va aprovar el dia 22 d'abril de 2010 pel Consell de Govern, sent directora de la Unitat d'Igualtat la professora Amparo Garrigues Giménez. La present publicació inclou els resultats de les accions núm. 64 i 65 del I Pla d'Igualtat, incloses en l'Eix 2, denominat «El treball a la Universitat Jaume I (PDI i PAS). La conciliació i la coresponsabilitat», Àrea 3. «Enfortiment de les possibilitats de conciliació de la vida personal, familiar i laboral des de la coresponsabilitat d'homes i dones».

Les dites accions fan referència a la realització d'una enquesta entre el PDI i el PAS per a conèixer les necessitats en matèria de conciliació de la vida familiar i laboral. L'enquesta es va realitzar gràcies a una subvenció de l'Institut de la Dona del Govern d'Espanya.

Per al disseny del qüestionari es va formar un equip de treball, les autores $\mathrm{i}$ autors del text que presentem, format per representants de l'Institut d'Investigació Feminista Purificación Escribano, de la Fundació Isonomia i de la Unitat d'Igualtat de l'usI, així com dels següents grups d'investigació relacionats amb estudis de gènere: Equip wonT, de Prevenció Psicosocial; Equip d'Investigació de Dret i Gènere i Equip d'Investigació de Sociologia i Gènere.

Una vegada dissenyat el qüestionari, l'Oficina de Promoció i Avaluació de la Qualitat (OPAQ) de la Universitat es va encarregar de passar el qüestionari a la mostra seleccionada i representativa del personal de la Universitat durant el mes de juliol i la primera setmana de setembre.

Posteriorment, van realitzar l'anàlisi dels resultats, els quals formen part del contingut d'aquesta publicació i que ens permeten conèixer millor les necessitats que tant el personal d'administració i serveis 
(PAS) com el personal docent $\mathrm{i}$ investigador (PDI) tenen respecte de la conciliació de la vida laboral i familiar.

El llibre l'hem estructurat de la manera següent: en el primer capítol es dóna una visió històrica i teòrica sobre la divisió de rols entre homes i dones en la societat, així com dels canvis succeïts en el transcurs del temps i que han conduït a una reestructuració dels rols i dels temps dels gèneres.

Posteriorment, s'al·ludeix a les diverses estratègies que s'utilitzen per a conciliar els temps de treball i d'atenció o dedicació a la vida familiar i, finalment, es conclou amb una referència europea i internacional en relació a aquest tema i a la seua inclusió en l'agenda política i mediàtica.

En el segon capítol exposem la normativa vigent en l'actualitat a la Universitat Jaume I referent a la conciliació de la vida laboral i la vida familiar.

El tercer capítol proporciona una breu descripció sobre la situació del personal a l'us per sexe, edat, nombre de fills i filles i categoria laboral en el moment actual així com el 1991, data de creació de la Universitat, amb l'objectiu de constatar els canvis i/o permanències que s'hi han produït.

El quart capítol exposa els resultats de l'enquesta referint-nos als aspectes següents: el grau de coneixement i d'utilització de les mesures de conciliació per part dels treballadors i treballadores de la Universitat; com es distribueixen les tasques domèstiques a les seues llars així com l'opinió i percepció que les persones entrevistades tenen sobre això; i, finalment, ens referirem al grau de dificultat que tenen per a conciliar la vida laboral i la familiar.

Finalment, s'inclouen les conclusions sobre la situació del personal a la Universitat respecte a la conciliació de la vida laboral i familiar, així com les propostes relacionades amb les necessitats manifestades en l'estudi i que indubtablement tenen repercussions en les nostres vides.

En l'annex s'inclou la fitxa tècnica de l'enquesta realitzada i els qüestionaris enviats al PDI $i$ al PAS. 


\section{CAPÍTOL I \\ LA CONCILIACIÓ DE LA VIDA LABORAL \\ I LA VIDA FAMILIAR: CONTEXTUALITZACIÓ \\ TEÒRICA I ANALÍTICA}

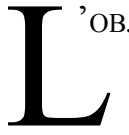

'OBJECTIU PRINCIPAL d'aquest capítol consisteix a introduir el lector

o lectora en el tema de la conciliació de la vida laboral i la

vida familiar des d'una triple perspectiva: la perspectiva històrica, pel que fa a com es va configurar la divisió sexual del treball en la nostra societat; la perspectiva teòrica, incloent-hi, en primer lloc, les propostes elaborades per les distintes disciplines que s'han ocupat de l'estudi de la conciliació i que reflecteixen, d'aquesta manera, la perspectiva multidisciplinària del tema $i$, en segon lloc, una breu referència a les diverses estratègies relacionades amb la conciliació; i la perspectiva política, en la qual ens centrarem en la incorporació de la conciliació a l'agenda política tant internacional com estatal, donant lloc a l'aprovació de diverses normatives reguladores i polítiques públiques amb el propòsit d'aconseguir una major equitat entre dones $\mathrm{i}$ homes en la nostra societat.

Iniciem l'exposició amb el primer dels objectius assenyalats.

\section{LA CONSTRUCCIÓ SOCIAL DELS GÈNERES: DE LA SEPARACIÓ A LA CONCILIACIÓ DE ROLS I ESPAIS}

Com a pas previ a la referència teòrica sobre la conciliació no podem obviar una breu introducció històrica que ubique com es va realitzar la construcció del sistema de gèneres en la modernitat, així com sobre els successius canvis que s'han esdevingut. 
Aquestes modificacions s'han produït des de la seua construcció inicial en el segle XIX fins a l'actualitat i es relacionen amb variables estructurals polítiques i econòmiques, així com amb la pressió exercida pels moviments socials feministes des del segle XIX.

\subsection{EL PATRIARCAT: DIVISIÓ DE ROLS I D’ESPAIS}

La divisió dels espais públic i privat-domèstic i la seua adjudicació per sexes es va realitzar amb la introducció del nou sistema de producció econòmica -la industrialització- (Bock, 2001) que va suposar una separació entre el lloc de treball remunerat i el lloc de reproducció de la força de treball, denominat generalment com a àmbit domèstic.

Cal dir que, amb anterioritat, ja s'havia construït el patriarcat polític en quedar excloses les dones de la ciutadania política proclamada per la revolució. ${ }^{1}$

A continuació definirem millor el significat d'espai públic i d'espai privat.

L'espai públic es va configurar amb l'establiment del sistema polític parlamentari com a àmbit de decisió i gestió de la societat. Amb la celebració de les eleccions democràtiques es va instituir la possibilitat de votar, com a electors, i de ser triats i triades; possibilitat que no va ser universal des del principi en incloure's una sèrie de condicions relatives al sexe, l'edat, la raça, la posició econòmica i el nivell d'instrucció com a delimitadores de la possibilitat o exclusió de considerar-se «ciutadà», com una nova categoria sorgida de la Revolució i que suposava ser subjecte ple de drets.

Posteriorment, es va desenvolupar la Revolució industrial i la divisió entre rols i espais va acabar de formalitzar-se i es va establir la divisió sexual del treball -nova organització social que va ser acordada entre els empresaris, l'Estat $i$ els sindicats- i que assignava que

1. En referència a la Declaració de Drets de l'Home i del Ciutadà de 1791. 
els homes foren els proveïdors o sustentadors i les dones es quedaren com a cuidadores i encarregades de la reproducció de la força de treball.

L'espai públic se li va adjudicar als homes en el nou sistema de gèneres establit, i es va constituir així el «patriarcat» (Amorós i de Miguel, 2005; Lerner, 1990; Walby, 1990), el qual, a més d'elaborar unes normes per al seu compliment -incloses en les constitucions, en el Codi civil o en el Codi penal- es va recolzar en altres institucions per a construir els rols i identitats de gènere, com van ser l'Església i el sistema educatiu, a més del suport ideològic de diversos intel·lectuals ${ }^{2}$ i científics. ${ }^{3}$

Pel que fa al denominat espai domèstic, experimenta una reconceptualització i un canvi de significat amb la generalització de la industrialització, en desplaçar-se el treballador o treballadora fins a un centre de producció allunyat de l'entorn domèstic i familiar. L'espai domèstic deixa així de considerar-se com a espai productiu, com a economia familiar de subsistència, perdent valor $\mathrm{i}$ control sobre el nou concepte de treball, ara indissociable del salari, ${ }^{4}$ i quedant com a lloc per a la reproducció de la força de treball.

S'adjudica a les dones la responsabilitat i l'exercici d'aquest espai, la qual cosa suposa un treball si per treball entenem «qualsevol activitat que implique un desgast físic o psíquic d'energia» (Borderías, Carrasco i Alemany, 1994), però no ho suposa si es relaciona amb un salari en l'acabada de constituir economia capitalista monetària.

El rol assignat a les dones en la família és el de cuidadores, proveïdores de necessitats de cura i atenció de la reproducció de la força de treball i de les necessitats afectives dels distints membres de la

2. Recordem J. J. Rousseau amb l'educació diferent per a Emili o Sofia, o a Durkheim amb la seua divisió sexual del treball.

3. L'any 1900, el filòsof, teòleg i metge alemany Paul Julius Moebius, va publicar La inferioritat mental de la dona (Calvo, 2002).

4. Això no vol dir que les dones no treballaven, ho feien, i molt, però dels seus treballs, en el camp, com a ajuda familiar o en l'economia informal, o no rebien salari o, si en rebien, no constava com a tal en el PIB. 
família, ja siguen menors, malalts o gent gran; rol que les fa invisibles socialment i queden apartades - marginades- de l'espai públic, ja siga polític, econòmic, laboral o cultural.

El patriarcat, com a nou sistema de gèneres, es va normativitzar en el Codi de Napoleó de 1804. Aquest text, aplicat posteriorment a altres codis civils europeus, i posteriorment llatinoamericans, consolidava la família patriarcal, amb el baró com a cap de família i la dona com a «menor jurídica», dependent del marit en tots els aspectes. ${ }^{5}$

És a dir, les dones invisibles com a subjectes polítics i legals, depenien del baró, el qual els garantia seguretat i «lloc de treball», ${ }^{6}$ sense remunerar lògicament; la seua activitat econòmica era invisible perquè no s'incloïa en el producte interior brut estatal.

Així es van constituir, les altres, en la terminologia de Simone de Beauvoir (2000), allunyades de la ipseïtat i de constituir-se en subjectes públics, dedicades quasi en exclusivitat a viure per als altres membres de la família.

Per a ajudar a construir els espais i els rols assignats segons el gènere es va elaborar el discurs de la domesticitat (Ballarin, 1995; Nash, 1994), necessari perquè les dones l'interioritzaren com a part de la seua identitat de gènere. La domesticitat és un comportament, una disposició a prestar atenció i donar resposta a les necessitats de l'altre, a anteposar les necessitats dels altres a les pròpies. Les dones queden així dedicades a la reproducció de la força de treball i a tenir cura dels membres de la família en situació de dependència, persones malaltes, xiquets i xiquetes i persones grans.

El discurs de la domesticitat, en relació amb la definició social dels gèneres, el defineix Mary Nash (1994) com «el conjunt de creences,

5. En el Llibre I del Codi dedicat a les persones s'inclou el següent article «El marit té el deure de mantenir la dona que s'ocupa de la llar, i aquesta última no pot contractar ni disposar dels béns sense consentiment del cònjuge, ni presentar-se a judici com a demandant sense la seua autorització». Queda en evidència l'allunyament de la dona de la vida pública i tot el que això comporta.

6. Señala M. Jesús Izquierdo que «ser casada és estar ocupada domèsticament» (Izquierdo, 1995). 
valors i normes àmpliament compartits pels membres d'una societat». El dit discurs s'afirmava amb l'establiment de:

- Una ideologia sexual: entenent-la com el conjunt coherent de creences que orienten les persones cap a una manera concreta d'entendre i valorar el món, creant d'aquesta manera una identitat pròpia en relació amb el sexe que és més permanent.

- Unes normes sexuals: en referència a les expectatives compartides sobre quina és la conducta adequada. Les normes s'aprenen en el procés de socialització transmès a través de diversos agents de socialització com són la família, l'escola, la religió, els mitjans de comunicació i els amics i les amigues.

- Uns estereotips sexuals: entenent per això les expectatives o idees preconcebudes que es tenen o s'esperen de cada sexe. Els mitjans de comunicació i la publicitat són importants a l'hora de configurar o canviar els dits estereotips.

Ara bé, el nou sistema de gèneres que assignava espais diferents segons el gènere va establir també una jerarquia entre aquests. En la cúspide jeràrquica se situen els homes, ells són els que tenen accés als recursos per la qual cosa tenen el poder i el que és més important, «el poder de la microdefinició» (Saltzman, 1992). ${ }^{7}$

En la nova economia que s'estava expandint, centrada en la producció industrial, a l'espai públic -masculí-se li assignava una jerarquia superior, un valor de què mancava l'espai domèstic o femení que «no produïa res». S'inicia ací, doncs, tant el procés de diferenciació com el de jerarquització entre els dos espais, tema que s'ha tractat de canviar en els últims temps per considerar-lo una discriminació òbvia entre els gèneres $i$ un atemptat contra la igualtat d'oportunitats.

7. Aquesta autora el defineix com «el poder de definir la realitat o la situació cap a la qual s'orienten les persones que interactuen: què és i què no és digne d'atenció i sobretot d'estudi; què és i que no és conducta «adequada» en la situació d'interacció concreta». 
En resum, en la configuració del sistema de gèneres patriarcal, els espais, «i rols», van quedar adjudicats de la manera següent: als homes, l'exercici del rol públic i el gaudi de l'espai privat com a activitat centrada a dedicar-se a un mateix. Per a les dones, el rol domèstic i la privació de si mateixes, cuidar els altres i ser les altres.

A continuació exposarem els canvis succeïts al llarg del segle xx $\mathrm{i}$ que van alterar el tradicional sistema patriarcal desigualitari.

\subsection{MODIFICACIONS EN EL SISTEMA PATRIARCAL: LA INCORPORACIÓ DE LES DONES AL MERCAT LABORAL}

Al llarg del segle xx es van produir una sèrie d'esdeveniments que van suposar importants transformacions del sistema de gènere anterior (Alcañiz, 2004):

- La Declaració Universal dels Drets Humans de 1948, amb el reconeixement explícit i universal de la igualtat i punt de partida en la creació de l'objectiu d'igualtat entre els sexes en les Nacions Unides i transmès posteriorment als Estats, com a encarregats d'implementar-lo en els seus textos legals i en les seues polítiques.

- La universalització del dret al vot femení en la majoria dels països de l'àmbit occidental, reivindicació iniciada pel moviment feminista anglès i nord-americà a finals del segle XIX com a exigència per a obtenir el dret de ciutadania per a les dones.

- El sorgiment del denominat feminisme de segona onada (Beltrán i Maquieira, 2001) que exigia una igualtat real entre homes i dones i una major participació d'aquestes en la vida pública més enllà del dret al vot.

- La universalització i gratuïtat del sistema educatiu, assumit pels estats del benestar. Fet que va eliminar el discurs de la 
domesticitat previ en unificar-se els continguts del sistema educatiu sense distinció dels gèneres.

- L'increment del sector serveis de l'economia, que suposa una oferta de llocs de treball que seran ocupats per dones, en un procés continu de feminització del sector serveis.

- La revolució dels anticonceptius, que va alterar la tradicional relació entre sexualitat i reproducció i que va tenir transcendents conseqüències en la vida familiar junt amb la revolució tecnològica dels electrodomèstics.

- El procés d'industrialització que va afectar els països europeus després de la Segona Guerra Mundial i que demanava mà d'obra, fet que va afectar les dones i la seua definició prèvia com a rol reproductiu en exclusiva.

A continuació ens centrarem en aquest últim punt, ja que considerem que la incorporació laboral femenina ha sigut una de les variables centrals en els canvis succeïts i té una relació més pròxima amb l'objectiu de la present publicació, centrada en la conciliació de la vida laboral i familiar.

En els anys setanta del segle passat la participació laboral femenina a Espanya era baixa: només un $20 \%$ de la població femenina (Durán, 1972) estava incorporada al mercat laboral i d'aquest nombre, un percentatge molt important eren les dones joves.

La situació econòmica de producció i consum, les normatives legals $i$ les polítiques públiques en pro de la igualtat $i$ els canvis en les identitats de gènere han modificat, sens dubte, els comportaments de gènere anteriors.

Les taules següents mostren el procés creixent d'incorporació de les dones al mercat laboral.

La primera taula descriu la població activa. Com es pot observar, la taxa d'activitat femenina ha augmentat en quasi 20 punts en els últims 20 anys. Aquest canvi espectacular s'ha realitzat en bona ma- 
nera a costa d'haver de realitzar les dones una «doble jornada», amb el consegüent cansament i esgotament físic i mental.

Taula 1.

Taxa d'activitat per sexe (\%)

\begin{tabular}{llllllll} 
& $\mathbf{1 9 9 1}$ & $\mathbf{1 9 9 6}$ & $\mathbf{2 0 0 1}$ & $\mathbf{2 0 0 6}$ & $\mathbf{2 0 1 0}$ & $\mathbf{2 0 1 2}$ & $\mathbf{2 0 1 3}$ \\
Homes & 68,09 & 65,17 & 66,55 & 69,0 & 67,72 & 66,93 & 65,90 \\
\hline Dones & 34,98 & 38,54 & 40,96 & 48,5 & 52,60 & 53,39 & 53,31 \\
\hline
\end{tabular}

Font: elaboració pròpia. Enquesta de població activa (EPA) (INE). Població de 16 anys i més. *Últim trimestre de 2013.

La menor activitat de les dones té com un dels seus principals motius les raons familiars (1. ${ }^{\text {r }}$ Informe sobre la desigualdad en España, 2013) fet que comporta que moltes dones amb fills i filles a càrrec seu deixen de treballar per l'absència d'infraestructures públiques de suport a l'atenció d'aquests, per la prevalença del model tradicional del rol d'atenció o perquè, d'acord amb la teoria del Premi Nobel d'Economia Gary Becker (1981), l'avantatge comparatiu dels homes davant el mercat laboral és millor per a aquests, per la qual cosa la parella decideix que siga la dona la que abandone l'ocupació.

En la taula següent es descriu exclusivament la població que està ocupada en el moment de realització de l'Enquesta de població activa (EPA). En aquest cas, si bé l'augment no és tan espectacular sí que ho és si el comparem amb la dada de 1970; en aquest cas l'increment és de dinou punts percentuals entre les dues dates pel que fa a les dones que realment estan ocupant un lloc de treball en el mercat laboral. 


\section{Taula 2.}

Taxa d'ocupació per sexe (\%)

\begin{tabular}{lllllll} 
& $\mathbf{1 9 9 6}$ & $\mathbf{2 0 0 1}$ & $\mathbf{2 0 0 6}$ & $\mathbf{2 0 1 0}$ & $\mathbf{2 0 1 2}$ & $\mathbf{2 0 1 3 *}$ \\
Homes & 54,13 & 61,47 & 64,81 & 55,44 & 50,38 & 49,22 \\
\hline Dones & 27,36 & 34,71 & 43,05 & 41,84 & 39,83 & 38,98 \\
\hline
\end{tabular}

Font: elaboració pròpia. EPA (INE). Població de 16 anys i més. *Últim trimestre de 2013.

Les dues taules anteriors són indicatives de dos processos inversos: d'una banda, el progressiu creixement de la participació laboral femenina i la disminució lleugera, però disminució al cap i a la fi, de la participació masculina.

La disminució de l'activitat masculina ha estat motivada per la crisi en la construcció, que va suposar la fi de la bombolla immobiliària a Espanya, i pel procés de deslocalització industrial a altres països, considerades ambdues, construcció i indústria, activitats majoritàriament realitzades pels homes.

En el context de desocupació masculina més elevada, moltes dones han hagut d'incorporar-se al mercat laboral i fer-ho en situacions de més vulnerabilitat.

Si l'ocupació remunerada és el principal factor d'estructuració en la societat actual, en tant que accés a recursos econòmics i estatus social, està clar que les dones s'hi han introduït i de moment no pareix que hi haja marxa enrere, però, $i$ açò és important, ho han fet en les mateixes condicions que els homes? o com diu Marcela Lagarde (1997) «les dones s'incorporen al mercat laboral amb tota la càrrega del seu rol tradicional», per la qual cosa la situació no pareix que siga molt semblant, més aviat denota una desigualtat de partida entre els gèneres que tindrà efectes visibles en les trajectòries laborals de les dones. 
En resum, la incorporació de les dones al mercat laboral no va alterar l'exercici tradicional que les dones realitzaven en l'àmbit domèstic, per la qual cosa les dones van exercir dues tasques: la tradicional, la dedicació domèstica i d'atenció, «expressiva» en terminologia parsoniana ${ }^{8} \mathrm{i}$ la laboral remunerada, anteriorment exercida prioritàriament pels barons. És ací quan s'encunya l'expressió doble jornada o doble presència (Balbo, 1994; Durán, 1986; Friedan, 1983).

No es conciliaven dues tasques anteriorment assignades segons el sexe, sinó que un sexe, el femení, compaginava les dues tasques sense que l'altre sexe, el masculí, s'implicara gens ni mica en l'altra tasca considerada com a exclusivament femenina. Respecte al denominat espai privat, poc cal dir, els homes continuaven tenint el seu temps per a ocupar-se de si mateixos, en activitats que anaven per descomptat canviant segons l'evolució de la societat i que variava de l'assistència a les tertúlies de casino a la pràctica d'esports, etc., mentre que les dones, acabades d'incorporar a l'espai públic, laboral especialment, no aconseguien disposar d'espai privat, temps per a elles mateixes, perquè, com en l'època anterior, els espais domèstic $i$ privat anaven units.

El temps privat, en paraules de Soledad Murillo (2006), és diferent per a un sexe i per a l'altre: en les dones el temps privat es confon amb el domèstic, mentre que en l'home és temps per a si mateix.

Aquestes diferències en els usos del temps entre dones $\mathrm{i}$ homes reflecteixen la desigualtat quant a l'exercici de treballs -laboral i domèstic- $\mathrm{i}$ quant al temps lliure, com a expressió de temps personal, disponible per a un mateix o una mateixa.

Vegem en la següent taula el repartiment dels temps entre dones i homes.

8. Ens referim al sociòleg nord-americà Talcott Parsons, que va definir els rols de gènere en l'interior de la família en aquests termes. 


\section{Taula 3.}

Usos del temps segons sexe

\begin{tabular}{|c|c|c|c|c|}
\hline & \multicolumn{2}{|c|}{ 2002-2003 } & \multicolumn{2}{|c|}{ 2009-2001 } \\
\hline & Dones & Homes & Dones & Homes \\
\hline $\begin{array}{l}\text { Atenció } \\
\text { personal }\end{array}$ & 11 h $21{ }^{\prime}$ & 11 h 24' & 11 h 26’ & 11 h 33' \\
\hline $\begin{array}{l}\text { Llar i } \\
\text { família }\end{array}$ & 4 h 24 & $1 \mathrm{~h} 30^{\prime}$ & $4 \mathrm{~h} 7$ & 1 h $54^{\prime}$ \\
\hline Estudis & 0 h $43^{\prime}$ & $0 \mathrm{~h} 42^{\prime}$ & 0 h $39^{\prime}$ & 0 h $39^{\prime}$ \\
\hline $\begin{array}{l}\text { Treball } \\
\text { remunerat }\end{array}$ & $1 \mathrm{~h} 57^{\prime}$ & 4 h $4^{\prime}$ & 2 h $9^{\prime}$ & 3 h $25^{\prime}$ \\
\hline Temps lliure & 4 h $26^{\prime}$ & $5 \mathrm{~h} 20^{\prime}$ & 4 h $32^{\prime}$ & 5 h $23^{\prime}$ \\
\hline
\end{tabular}

Font: elaboració pròpia basada en enquestes de temps de l'INE 2002-2003 i 2009-2010.

La taula mostra la variació entre els anys considerats, confirmant allò que s'ha apuntat en una taula anterior pel que fa a la progressiva participació de les dones en el mercat laboral i la disminució de la dels homes. També mostra la gran diferència entre els uns i les altres pel que fa al temps dedicat a les tasques domèstiques i d'atenció, i que es constitueix en un factor explicatiu en les desigualtats que tenen lloc en l'àmbit productiu.

Crida també l'atenció que els homes disposen de més temps lliure que les dones. 


\section{Taula 4.}

Temps dedicat a la llar i la família, segons el tipus d'activitat

\begin{tabular}{|c|c|c|c|c|}
\hline & \multicolumn{2}{|c|}{$2002-2003$} & \multicolumn{2}{|c|}{ 2009-2010 } \\
\hline & Dones & Homes & Dones & Homes \\
\hline $\begin{array}{l}\text { Activitats no } \\
\text { especificades }\end{array}$ & & & $0 \mathrm{~h} 15^{\prime}$ & $0 \mathrm{~h} 4^{\prime}$ \\
\hline Activitats culinàries & $1 \mathrm{~h} 38^{\prime}$ & $0 \mathrm{~h} 22^{\prime}$ & $1 \mathrm{~h} 24$ & $0 \mathrm{~h} 26^{\prime}$ \\
\hline Manteniment de la llar & $0 \mathrm{~h} 56^{\prime}$ & $0 \mathrm{~h} 13^{\prime}$ & $0 \mathrm{~h} \mathrm{49}$ & $0 \mathrm{~h} 17^{\prime}$ \\
\hline $\begin{array}{l}\text { Confecció i cura } \\
\text { de la roba }\end{array}$ & oh 29' & Oh $1^{\prime}$ & $0 \mathrm{~h} 23^{\prime}$ & Oh 1 \\
\hline Compres i serveis & $0 \mathrm{~h} 32^{\prime}$ & $0 \mathrm{~h} 18$ & $0 \mathrm{~h} 31^{\prime}$ & $0 \mathrm{~h} 20$ \\
\hline Atenció a menors & $0 \mathrm{~h} 24^{\prime}$ & $0 \mathrm{~h} 10^{\prime}$ & $0 \mathrm{~h} 32^{\prime}$ & $0 \mathrm{~h} 18^{\prime}$ \\
\hline
\end{tabular}

Font: elaboració pròpia basada en enquestes de temps de l'INE.

En la taula anterior s'observa la gran diferència entre dones i homes pel que fa al temps dedicat a les activitats domèstiques i de cures. Les tasques amb menys diferència són les compres i serveis i l'atenció als menors.

En el primer cas es relaciona amb la hipòtesi plantejada per Man Yee Khan i Jonathan Gershuny (2010) sobre l'existència d'una segregació per gènere en les tasques domèstiques. Les dones realitzen més les tasques rutinàries, que són les més rígides, i els homes realitzen aquelles menys rutinàries. 
En el cas de l'atenció a xiquets i xiquetes l'explicació la situen aquests autors en la recompensa emocional que suposa la dita dedicació, més gran, sens dubte, que la que proporcionen les tasques domèstiques «més dures».

En el següent punt tractarem les accions realitzades per a intentar modificar la desigual participació de dones i homes en les tasques domèstiques i de cures. És ací on es va plantejar la denominada «conciliació entre la vida laboral i familiar».

\subsection{LA CONCILIACIÓ DE LA VIDA LABORAL I FAMILIAR: UNA PROPOSTA DE CANVI PER ALS HOMES I LES DONES, O NOMÉS PER A LES DONES?}

Des del punt de vista normatiu i d'actuació internacional en pro de la desconstrucció del sistema de rols tradicional, va ser l'última Conferència Mundial sobre les Dones, celebrada a Pequín (Xina) el $1995,{ }^{9}$ la que va impulsar amb més ímpetu la idea de conciliació i la necessitat d'adoptar noves mesures per a aconseguir-ho en reflexionar sobre els escassos resultats obtinguts en el tema de la igualtat entre els gèneres a pesar de l'organització d'esdeveniments internacionals. La resposta apuntada a aquest fet va ser que mentre les dones foren les úniques responsables de les tasques domèstiques i d'atenció, la igualtat no era possible, per la qual cosa, o s'incidia també en el canvi dels homes, o no hi havia res a fer.

Les anteriors conferències mundials (Mèxic 1975, Copenhaguen 1980 i Nairobi 1985) van centrar els seus objectius a aconseguir la igualtat legal de les dones respecte dels homes i a incentivar la participació de les dones en el mercat laboral i en el públic, però sense cap referència explícita a l'altra part, és a dir, als homes.

Des d'aquesta data, 1995, es va produir un gir epistemològic en les normatives sobre la igualtat entre els gèneres així com en les políti-

9. www.nu.org/womenwatch 
ques públiques en la Unió Europea, ${ }^{10}$ ja que a partir d'aquest moment, els homes seran considerats també com a objecte de canvi, en intentar, tímidament, que es modificara el seu rol anterior i exclusiu de «sustentador de la família (breadwinner) públic» i que s’incorporen també a l'àmbit domèstic, d'atenció. ${ }^{11}$ Clar que per a això s'hauria de modificar al mateix temps la cultura de gènere masculina, allunyada per complet dels valors centrats en l'atenció als altres i en la reproducció de la força de treball i centrar-se més en la proposta realitzada per les feministes sobre la denominada «ètica de l'atenció» (Comins, 2008; Gilligan, 1996).

Amb la denominada «conciliació»» el que es pretén és que les dones no realitzen els dos rols, el de dins i el de fora, la denominada «doble jornada» (Friedan, 1983) o doble presència (Balbo, 1994), sinó que ambdós àmbits siguen compartits pels dos gèneres. Açò suposa una desespecialització dels gèneres segons el pressupost construït en el patriarcat i una ocupació dels espais públic i domèstic o familiar per individus, més que per gèneres (Alcañiz, 2004).

En aquesta etapa es produeix un canvi en les disposicions normatives relacionades amb la incorporació de les dones al mercat laboral, ja que es passa de la consideració d'uns drets proteccionistes, basats en consideracions purament biològiques, com ara la maternitat i que comportava la consideració que la responsabilitat familiar era exclusiva de les dones, com a mares biològiques, a una accepció més àmplia, en referència al fet de no suposar la maternitat com a generadora de drets, sinó la responsabilitat familiar en el seu conjunt i de forma especial als membres dependents, és a dir, als xiquets i xiquetes i a les persones grans, d'ací la conclusió que l'home també és subjecte dels dits drets i obligacions, és a dir, de l'atenció.

10. Desgraciadament, poca cosa s'ha fet en altres països.

11. En aquest aspecte hi ha una gran diferència entre la incorporació de les dones a l'àmbit públic, realitzada en part per la pressió del moviment feminista, i la incorporació dels homes a l'àmbit domèstic, no demanada per cap moviment masculí, sinó pel mateix moviment feminista i l'agenda política. 
La complexitat del tema de la conciliació entre la vida personal i laboral es reflecteix en la perspectiva multidisciplinària que aborda la qüestió que manifesta l'amplitud en el tractament donat al seu estudi des de diferents disciplines. A continuació presentem un breu esbós de l'anàlisi efectuada des de la sociologia, l'economia, els recursos humans i el feminisme crític, deixant l'anàlisi jurídica i normativa per al capítol segon.

Des de la sociologia s'han realitzat nombrosos estudis teòrics i empírics sobre la conciliació entre la vida familiar, laboral i personal (Alcañiz, 2008 i 2013; Crompton i Lyonette, 2010; Hakim, 2005; RiveroRecuenco, 2005; Sarraceno, 2004; Tobío, 2005; Torns, Borrás, Recio i Moreno, 2011; Torns, 2005).

Aquesta disciplina té com un dels seus objectes d'estudi l'anàlisi dels rols i estatus dels individus en la societat així com dels seus canvis. La incorporació de les dones al mercat laboral, com hem vist més amunt, es considera motor important en el procés de transformació dels rols de gènere en les últimes dècades.

La sociologia estudia també com es realitza la interiorització dels rols per mitjà del procés de socialització a través de diversos agents socials, prioritàriament la família, l'escola, els mitjans de comunicació i el grup d'iguals.

En aquest primerenc procés d'aprenentatge social es construeixen les identitats femenina i masculina i s'estableix una clara diferenciació entre elles en tot allò que s'ha relacionat amb les tasques d'atenció. Com assenyala Rivera-Recuenco (2005), els continguts del dit rol d'atenció no es refereixen només a les tasques domèstiques i de fills i filles, sinó que van més enllà i acaben constituint-se en una actitud d'atenció constant que pot arribar a generar sentiments de culpa en el cas de no poder realitzar-les.

És així com Beauvoir (2005) va denominar les dones com «un ser per als altres», en clara referència al fet que les dones no vivien per a elles mateixes sinó per als altres. 
Amb l'arribada de les dones a l'ocupació remunerada, especialment de les dones amb criatures petites, s'ha generat en multitud de vegades un conflicte de rols entre l'exercici del rol tradicional i el modern. Atesa la coerció social que encara existeix en la societat respecte a l'exercici tradicional del rol d'atenció en les dones, el conflicte es resol moltes vegades amb l'abandó laboral, reducció de jornada o canvi d'una ocupació a una altra que s'adeqüe a la compatibilització d'ambdós rols i, d'aquesta manera, torna a recaure en les dones la major part dels «costos domèstics i d'atenció», la qual cosa no és sinó l'anomenada «doble jornada».

I es manifesta que perdura la consideració de l'ocupació de la dona com a segon treball de la família, és a dir, que l'ocupació del baró continua sent el principal i el de la dona el secundari, una espècie d' 'ajuda» per a aconseguir més benestar per a la família. Aquest estereotip encara persisteix en l'imaginari col-lectiu, perjudicant, si això és possible, el treball i la promoció de les dones.

No obstant això, juntament amb la incorporació de les dones al mercat laboral, s'ha produït un altre canvi important en el que s'ha relacionat amb la identitat pròpia de les dones: ens referim al denominat procés d'individualització (Beck i Beck-Gernsheim, 2003) el qual apunta que les dones joves ja no viuen el ser-per-a-altres com les seues antecessores, sinó que construeixen de forma més individual la seua biografia i ho fan atenint-se també a un desenvolupament laboral (Flórez-Estrada, 2011). Lipovetsky (2003) denomina a aquesta nova dona «la tercera dona» en relació al fet que per a aquesta dona, el seu ideal de vida ja no s'orienta exclusivament cap al matrimoni i la natalitat, sinó cap a valors més individuals.

En la perspectiva econòmica destaca la teoria de la nova economia familiar, desenvolupada en la dècada dels vuitanta del segle passat per l'economista Gary Becker.

El marc teòric de la nova economia familiar se sustenta en l'economia neoclàssica (Borderías, Carrasco i Alemany, 1994) i concep la família com una unitat racional que pren les seues decisions a partir 
de mètodes d'anàlisi de costos. És a dir, la parella decideix qui ha de treballar fora o dins en funció del cost d'oportunitat, és a dir, que el cost d'abandonar el mercat laboral serà més alt per al membre de la parella amb més estudis o amb un lloc de treball millor retribuit.

Segons aquesta perspectiva, i atesa la divisió sexual del treball en la nostra societat, es decideix que siga la dona la que es quede a casa realitzant les tasques domèstiques, invisibles des del punt de vista mercantil.

En resposta a aquesta proposta teòrica, les economistes feministes van reivindicar la importància del treball reproductiu i la seua visibilització en els resultats del PIB i es va començar a mesurar a través dels denominats «comptes satèl-lits» (Carrasco i Serrano, 2007; Durán, 2005) que incloïen el valor que representa el treball reproductiu aparentment sense cost però que ho té quan, en comptes de ser la dona de la família la que realitza les activitats domèstiques $i$ d'atenció, el realitzen altres dones ocupades per a tal fi i que reben un salari per això.

Des del punt de vista econòmic i laboral s'incideix en la segregació del mercat laboral en ocupacions masculines i femenines, considerant les femenines més pròximes a tasques d'atenció, de serveis als altres, i pitjor remunerades.

Aquesta segregació, juntament amb la pitjor posició de les dones en les jerarquies laborals, porta al fet que es produïsca «una bretxa de gènere» pel que fa a la diferència en les retribucions entre dones i homes.

Segons el document presentat per la UGT, ${ }^{12}$ la bretxa salarial entre dones i homes és del $22.99 \%$, és a dir, que en 2011 els homes van cobrar una mitjana de 25,667 euros anuals i les dones 19.767 euros.

Des de la perspectiva dels recursos humans ens centrem en les polítiques i actuacions que duen a terme les empreses en relació amb la conciliació, tenint en compte que les empreses, a més de complir amb la normativa vigent en aquesta matèria, busquen incrementar la productivitat dels seus treballadors i treballadores considerant que un

12. Consultat en www.elpais.es el 17 de febrer de 2014. 
entorn més favorable a les pràctiques de conciliació incidirà en un clima laboral positivament i conseqüentment en la productivitat, la qual pot incrementar-se en un $15 \%$ (Observatori de Recursos Humans, 2011).

Des d'aquesta perspectiva, més instrumental que les anteriors, es considera que una empresa que implementa accions relacionades amb la conciliació obtindrà una sèrie de beneficis, entre els quals se situen la millora de la imatge corporativa de l'organització, millora del clima laboral, reducció de l'absentisme i augment de la productivitat.

Es parla que una empresa té cultura favorable a la conciliació (Albert et al., 2010) quan els seus mateixos directius tenen una actitud favorable i un compromís envers l'entitat. Això inclou que la política de comunicació de l'empresa funcione adequadament en transmetre aquest objectiu.

Així mateix, ha de ser una empresa sensibilitzada amb la coresponsabilitat, és a dir, no considerar que les polítiques i les mesures de conciliació són només per a ús de les dones, sinó que estan dirigides tant a les treballadores com als treballadors. És a dir, que una empresa amb cultura favorable a la conciliació considerarà que aquesta és neutra o assignada als dos sexes i no exclusivament femenina.

Distints estudis realitzats (Albert et al. 2010; Chinchilla, 2003) exposen que les principals polítiques de conciliació implementades per les empreses es refereixen a les mesures següents: flexibilitat, temps parcial, jornades comprimides, excedències, teletreball, política de serveis més enllà de la mateixa empresa, adaptació del lloc de treball i suport professional.

En resum, des de la perspectiva dels recursos humans la implementació de polítiques de conciliació es contempla com un mecanisme per a aconseguir un benefici més alt en relació amb la major satisfacció del treballador o treballadora.

Finalment, des de la perspectiva feminista crítica, l'anàlisi de la conciliació entre la vida familiar i la laboral procedeix de l'anàlisi que evidencia la subordinació de la reproducció a la producció i for- 
mant part d'aquesta, la dominació de les dones pels homes en el context d'un sistema patriarcal-capitalista.

Com assenyalen Combes i Haicault (1994), el sistema capitalista va assignar la funció reproductiva a la família, i després a l'Estat, amb la formalització de l'estat del benestar. En la família, com ja sabem, són les dones les encarregades de la dita funció, per la qual cosa en la divisió sexual del treball la seua funció queda supeditada a la productiva del baró i considerada invisible, no productiva, per al capital, que queda totalment separat d'aquestes tasques i considera que no té cap obligació d'assumir-les.

Amb la inclusió de la conciliació en l'agenda política es va pensar que es modificaria la tradicional divisió sexual del treball entre els gèneres, compartint dones $\mathrm{i}$ homes l'exercici d'una tasca o d'una altra, però des del feminisme crític s'ha arribat a una altra conclusió. Aquesta consisteix a afirmar que les polítiques de conciliació implementades no incideixen en la igualtat entre els gèneres per ser les dones les demandants majoritàries de les mesures incloses en les normatives jurídiques, tal com reflecteixen les enquestes, i les que continuen dedicant més temps a les tasques domèstiques i d'atenció, sinó que aquestes són, més prompte, polítiques d'ocupació (Campi1lo, 2010; Lapuerta, 2012) que contribueixen a generar més llocs de treball, això sí, a temps parcial i temporals, per a les dones.

La possibilitat de gaudir de les mesures de conciliació, majoritària per a les dones, ens fa reflexionar sobre si l'objectiu és que les dones treballen de manera remunerada però que ho facen a temps parcial, perquè així continuen ocupant-se del rol tradicional com abans.

Segons dades de l'Institut Nacional d'Estadística, ${ }^{13} 26$ de cada 100 dones treballen a temps parcial enfront de només 8 homes de cada 100 .

D'aquesta manera, el sistema de rols de gènere no canvia, es modifica. Continua la divisió sexual del treball però amb les dones treballant fora de casa menys temps perquè la «doble jornada» no siga tan dura i puguen realitzar les tasques domèstiques. Així succeeix ja

13. Consultat en www.ine.es el 4 de febrer de 2014. 
a Holanda i al Regne Unit, països amb una important taxa d'ocupació femenina però en treballs a temps parcial, la qual cosa no és indicativa de canvi sinó, com ja hem apuntat, de continuïtat pel que fa al desigual repartiment dels rols.

\section{ESTRATÈGIES I PRÀCTIQUES PER A LA CONCILIACIÓ DE LA VIDA LABORAL I LA VIDA FAMILIAR}

En aquest punt farem una breu exposició de les estratègies ${ }^{14}$ utilitzades per les dones per a conciliar el temps laboral i el temps d'atenció; tema que ha sigut àmpliament estudiat $i$ que ha passat a convertir-se en objecte d'anàlisi per se (Alcañiz, 2013; Carrasco, Torns i Borderías, 2012; Crompton i Lyonette, 2010; Hochschild, 1989; Rivero, 2005; Rodríguez i Peña, 2009; Tobío, 2005; Torns, 2005).

Atès que l'objectiu de la present publicació no se centra en aquest tema, a continuació proporcionem informació analitzada en les investigacions i estudis assenyalats, referint-nos en capítols posteriors de la publicació, exclusivament a l'estratègia vinculada a la utilització de mesures de conciliació pel personal de la Universitat Jaume I relacionades amb mesures estatals o de la Universitat obtingudes per mitjà de l'enquesta realitzada.

\subsection{ESTRATÈGIES RELACIONADES AMB LES NORMATIVES ESTATALS: LA CONCILIACIÓ PÚBLICA}

Durant anys, 1'Estat, com a institució política, no va incloure entre les seues competències la regulació ni l'ordenament de cap tema relacionat amb l'àmbit privat-familiar, ja que es deixava a la discreció del pater familias, autoritat absoluta en el dit àmbit, així consignada

14. L'estratègia al-ludeix a la presa d'una decisió en un entorn estructural i ideològic concret. 
des del Codi napoleònic de 1804 (Bock, 2001; Fraisse i Perrot, 1995; Morant, 2005), aprovat a França i estès posteriorment a la resta de països europeus i llatinoamericans.

Amb l'arribada de la democràcia i l'aprovació de la Constitució espanyola en 1978, es proclama el principi d'igualtat (articles 9 i 14) i comença l'adaptació de totes les normatives legals al dit principi. La desigualtat real continuava $i$, si bé les dones ja estaven incorporades al sistema educatiu i, en menor grau, al mercat laboral, la distribució tradicional entre els rols romania, produint-se la denominada «doble jornada» (Friedan, 1983), «the second shift» (Hoschild, 2003), «doble presència» (Balbo, 1994) o la «jornada interminable (Durán, 1986) amb un increment notable en l'activitat i cansament de les dones, continuant els homes en la mateixa situació anterior, és a dir, realitzant un rol exclusivament.

Després de la celebració de la IV Conferència Mundial a Pequín, celebrada el 1995, s'inicia el canvi normatiu d'àmbit europeu i estatal amb l'objectiu d'incidir en una major participació dels homes en les tasques domèstiques. A Espanya, s'aprova la Llei 39/1999, de 5 de novembre, de conciliació de la vida laboral i familiar de les persones treballadores i, posteriorment, la Llei orgànica 3/2007, de 22 de març, per a la igualtat efectiva de dones i homes. ${ }^{15}$

L'Estat, amb aquestes normatives, assumeix l'ajuda per a facilitar la conciliació a aquelles parelles amb criatures o familiars dependents, intentant no diferenciar el gènere del cònjuge que les utilitza, si bé i com exposarem a continuació, les solucions proposades són monopolitzades exclusivament per les dones i no es produeixen modificacions en les relacions entre els gèneres; simplement es facilita l'exercici del «nou» rol de treballadora remunerada a les dones en situació de criança.

En una investigació anterior (Alcañiz, 2008), constatem el canvi succeït en mostrar que les dones de la generació de més de seixanta

15. Salido (2011) estableix diferències entre ambdues normatives, considerant que la llei de 1999 no suposa una ruptura decisiva en la relació entre els gèneres. 
anys no havien gaudit de cap dret per part de l'administració pública en l'exercici del doble rol; treballar fora de casa era quelcom que havien de resoldre de forma privada, elles mateixes, ja que a l'Estat no pareixia importar-li en absolut aquest tema (ni tampoc a les seues parelles masculines).

En l'actualitat, a més d'allargar-se la baixa per maternitat s'inclouen altres drets, ${ }^{16}$ com ara la reducció de jornada i l'excedència, que contribueixen al fet que la utilització de les dites possibilitats es consideren estratègies per a combinar la «doble presència» de les dones en el mercat laboral. ${ }^{17}$ No obstant això, i a pesar de les possibilitats obertes per la llei perquè els homes puguen incorporar-se al treball d'atenció, continuen sent les dones les que gaudeixen d'aquests drets.

Així ho manifesten les dades sobre utilització de permisos, reduccions i excedències per a $2011:^{18}$ el 85,07 \% de les excedències concedides per a atenció de familiars dependents són gaudides per dones, així com el 93,80 \% de les sol·licitades per a atenció de fills i filles (en 2000 la proporció va ser del 96,02 \%). En el cas de reducció de jornada, el 97,17\% de les sol-licituds per motius d'atenció de xiquets i xiquetes, adults malalts, incapacitats o persones grans ha sigut realitzades per dones.

Tot això manifesta que, a pesar de ser mesures aparentment neutres, ja que excepte la baixa obligatòria per maternitat la resta poden gaudir-les el pare o per la mare, no ho són tant en la mesura que són utilitzades fonamentalment per les dones. Per això ens preguntem si l'Estat no estarà afavorint la fórmula de la doble presència per a les dones més que la conciliació entre els dos àmbits (producció/

16. Aquest punt es veurà amb més amplitud en el capítol següent.

17. Hadas Mandel (2009) en un article recent es planteja si el fet que els Estats socialdemòcrates accepten les demandes de les dones en relació amb el seu estatus de mares produeix efectes contraproduents en la situació laboral de les dones, ja que si bé aquestes continuen en el mercat laboral, els avantatges normatius que reben les acosta a ocupacions amb menys nivell ocupacional i menys salari.

18. www.institutomujer.es. Consultat el 20 d'abril de 2013. 
reproducció) per a ambdós gèneres; si, en definitiva, les polítiques de conciliació no seran més que polítiques d'ocupació (Borrás, Torns i Moreno, 2007; Campillo, 2010; Salido i Moreno, 2007), això sí, perquè les dones puguen compatibilitzar el treball remunerat sense deixar d'encarregar-se del treball de reproducció social-d'atenció i domèstic.

Com a conclusió, afirmem que si bé la institució política proporciona mecanismes per a ajustar l'exercici de les dues tasques, és principalment la dona la usuària principal, per la qual cosa no es pot afirmar que s'altere el sistema de gèneres. Les conseqüències en la seua utilització no beneficien la igualtat entre dones i homes, ja que, com a conseqüència d'aquesta doble presència, les dones continuen tenint menys probabilitats de promocionar i de continuar formant-se i més probabilitats de continuar en ocupacions precàries o amb major risc de vulnerabilitat (Mandel, 2009).

\subsection{ESTRATÈGIES I PRÀCTIQUES RELACIONADES AMB LES MESURES REGULADORES LABORALS}

En aquest grup s'inclouen les estratègies triades i les pràctiques aplicades que giren entorn de les condicions en el mercat laboral, àmbit considerat $\mathrm{amb}$ anterioritat com a «territori masculí».

Aquesta estratègia és utilitzada exclusivament per les dones i manifesta la posició de les dones en aquest terreny, la seua condició de treball secundari en la família. Dins de la utilització d'aquesta estratègia diferenciem diverses pràctiques: En primer lloc se situaria l'estratègia més extrema, la d'abandó indefinit o temporal (Tobío, 2005). Aquesta estratègia s'utilitza poc en els temps de crisi econòmica actuals, on els dos ingressos són necessaris, d'una banda, i d'una altra, les dones, cada vegada més, tenen interioritzat l'habitus de treballadora (Flórez-Estrada, 2011), per la qual cosa resulta difícil un retorn a la llar per part de les dones. No va ser així, com sabem, en 
els temps de la dictadura, on el règim «enviava» les dones casades de tornada a casa per a complir el seu mandat de gènere.

Actualment, atesa la situació de crisi econòmica i laboral, poques dones, excepte en parelles ben situades, poden permetre's renunciar a un salari, encara que siga un «mig treball» en referència a les ocupacions a temps parcial.

La segona iniciativa, vinculada amb el mercat laboral, consisteix a canviar de lloc de treball per a adequar-lo a les necessitats domèstiques (Carrasco, 2004; Hakim, 2005) com a manifestació de la primacia del rol tradicional i l'adequació del nou exercici de rol -l'ocupació- a l'anterior. També en aquest cas són les dones les que opten per aquesta elecció.

Finalment, situaríem les eleccions relacionades amb els canvis en la jornada laboral, en referència al treball a torns, a temps parcial ${ }^{19} \mathrm{O}$ amb jornada reduïda. Els torns com a estratègia de conciliació l'utilitzen dones en sectors molt concrets: grans superfícies, sanitat, policia, bombers, call centers i transports, entre altres. Si bé en alguns casos aquesta jornada laboral és imposada -com en la sanitat-en altres és triada, i el motiu que donen aquestes dones és tenir més facilitat per a combinar l'exercici dels dos rols i disposar d'un poc de temps lliure i tranquil-litat durant els matins quan estan tots els membres de la família fora de casa, a les escoles o al treball; i al mateix temps, de manera subreptícia, obliguen la parella a fer-se càrrec dels fills i filles en cas de la seua absència vespertina o de cap de setmana.

Com a conclusió d'aquesta estratègia referida a la utilització de normatives laborals legislades per al tema de la conciliació, observem que són les dones les que decideixen modificar la seua jornada laboral com a mecanisme de conciliació, resultat de la seua pròpia consideració de ser la treballadora secundària de la parella, o per la

19. Relacionat també amb l'anterior estratègia en el cas de sol-licitar reducció de jornada per cures. 
seua preferència, en la definició de Hakim (2005) en considerar més important l'atenció a la família que l'ocupació. ${ }^{20}$

\subsection{ESTRATÈGIES PRIVADES: LA SUBSTITUCIÓ DEL TREBALL DOMÈSTIC I D’ATENCIÓ}

$\mathrm{Si}$ amb anterioritat eren les dones les que realitzaven de manera exclusiva les tasques domèstiques i d'atenció, seguint el mandat de gènere patriarcal, aquesta situació canvia amb la seua incorporació al mercat laboral, fet que trastorna la dedicació anterior i implica, en el cas de continuar treballant fora de casa, buscar ajuda substitutòria que realitze les tasques domèstiques i d'atenció que anteriorment realitzava ella (Alcañiz, 2013).

Aquesta ajuda substitutòria pot ser de dues maneres: pagada, com si es tractara d'una «mercaderia», o solidària, realitzada fonamentalment per membres femenins de la família.

per externalització o mercantilització dels serveis domèstics $i$ d'atenció entenem l'ajuda privada pagada a què acudeixen les famílies per a atendre, en primer lloc, les necessitats d'atenció de les criatures dependents, per mitjà de la contractació del servei privat a casa o a través de la contractació d'una plaça en una guarderia; i, en segon lloc, per a realitzar les tasques de neteja i reproducció social. Si bé el denominat «servei domèstic» ha existit des de segles (Fraisse i Perrot, 1995), no tenia el mateix significat que en l'actualitat: de signe d'estatus i manifestació d'una estructura de classes molt concreta en la qual estava mal vist que la dona treballara perquè indicava o donava a entendre que el salari del baró no era prou, s'ha passat a la consideració d' «ocupació» en el context de substitució de la dona/ mare en el cas que aquesta s'incorpore al mercat laboral remunerat.

20. Segons Hakim (2005), les dones trien no l'ocupació sinó el lloc de treball que millor els permeta realitzar les tasques domèstiques i d'atenció. 
Assenyalen Martí i Poveda (2009) que l'ocupació del treball de la llar és una activitat que es desenvolupa, tant des del punt pràctic com simbòlic, en un univers femení. Són dones les que hi treballen, duent a terme tasques «femenines» $\mathrm{i}$ a instàncies d'altres dones de les quals sorgeix la demanda i amb les quals s'establirà una relació laboral.

En tot cas, i abans d'endinsar-nos en l'anàlisi, és necessari subratllar el fet que sempre, i per a ambdues tasques, la d'atenció i l'ajuda domèstica, són dones les contractades per a la seua realització; fet que manifesta i corrobora la continuïtat dels rols de gènere, si bé es produeix una diferenciació de classe (i d'ètnia) dins del gènere femení en ser dones amb posició social inferior, en molts casos immigrants, les que realitzen el treball de reproducció social per a altres dones amb més estatus i qualificació (Hochschild, 2001; Román i Martínez, 2005).

L'ajuda substitutòria de la família, especialment de les àvies i d'altres membres femenins de la família, i en algun cas concret dels avis, ${ }^{21}$ es concreta en les tasques d'atenció de les criatures.

Davant d'aquesta estratègia, les representants de la qual són les «dones sandvitx», denominades així perquè de vegades se'ls ajunta l'atenció a néts i nétes i als seus pares i/o mares, caldria advertir que segurament conclourà amb aquesta generació, ja que les generacions posteriors estan incorporades al mercat laboral i no podran fer-se càrrec de l'atenció perquè tindran les seues obligacions laborals.

Les ajudes realitzades per la família oscil·len des de temps complet a moments puntuals per a recollir els xiquets i xiquetes a l'eixida de la guarderia/escola, o a vesprades en què les filles/nores estan ocupades, o com a suport al servei pagat, necessitant en alguns casos l'ajuda per part de les dues àvies, i s'arriba de vegades a haver d'ajustar vertaders i complicats encaixos pel que fa a l'atenció de les criatures.

21. Més del $66 \%$ de les dones de més de 65 anys han cuidat en algun moment dels seus néts, segons l'enquesta de l'Imserso i el CIS. El 22,6 \% ho fan actualment, la meitat diàriament, com un treball fix. Algunes a temps complet, del matí a la nit. www.elpais.es consultat el 8 de setembre de 2011. 
La solució familiar d'ajuda femenina es basa en la xarxa de solidaritat familiar però també en la denominada sororitat femenina (Lagarde, 2009; ${ }^{22}$ Posada Kubissa, s/d ${ }^{23}$ ) basada en l'ajuda mútua establida generacionalment entre les dones per a la criança. Com he assenyalat, aquest suport està centrat en les dones, fonamentalment les àvies, puntualment, germanes i nebodes; i, només excepcionalment, avis.

Si bé l'ajuda de les àvies se centra en l'atenció dels néts i nétes, de vegades s'amplia el suport als àpats en el sentit que acudeixen a dinar a casa seua les filles quan van a arreplegar el fill o filla. Els avis, com comenta Radl Philipp (2003), es dediquen amb més freqüència a portar les criatures al col·legi i recollir-les i a acompanyar-los al parc a jugar.

En conclusió, la xarxa familiar continua sent una ajuda fonamental a Espanya, és el matalàs de benestar que substitueix en molts casos les estratègies públiques proporcionades per altres Estats europeus amb millors prestacions familiars (Esping-Andersen, 2010; Moreno i Salido, 2007;). Ara bé, en una prospectiva futura, s'hauria de plantejar quines estratègies substituiran la família quan les generacions de dones actuals -incorporades al mercat laboral- tinguen néts o nétes.

\section{LA INCORPORACIÓ DE LA CONCILIACIÓ EN L'AGENDA POLÍTICA INTERNACIONAL}

Com ja hem al·ludit en el punt anterior, en la IV Conferència Mundial de Dones celebrada a Pequín (Xina) en 1995 es va explicitar que transcorreguts vint anys des de la I Conferència Mundial celebrada a Ciutat de Mèxic en 1975, la igualtat entre homes i dones en l'accés a l'àmbit públic no havia millorat a pesar dels esforços realitzats, i es va arribar a la conclusió que la situació de desigualtat entre dones i

22. Consultat en www.mujeresenred.net el 23 d'octubre de 2011.

23. Ídem. 
homes no es modificaria mentre no canviaren les relacions de gènere i la distribució de rols en la llar.

Es va plantejar, doncs, per primera vegada, que el sistema de gèneres patriarcal hegemònic no podria modificar-se si no ho feien les dues parts al mateix temps. És a dir, no n'hi ha prou que les dones s'incorporen a l'àmbit públic, els homes també han d'incorporar-se a l'àmbit privat, domèstic $i$ de cures perquè realment es produïsca una transformació a un sistema de gèneres més igualitari.

En la Declaració i Plataforma d'Acció de Pequín es va incloure per primera vegada de forma expressa ${ }^{24}$ una referència al canvi dels homes respecte al sistema de gèneres en l'objectiu estratègic F.6., «Fomentar l'harmonització de les responsabilitats de les dones i els homes pel que fa al treball i la família».

a) Assegurar, per mitjà de lleis, incentius o estímuls, que es donen oportunitats adequades a les dones $\mathrm{i}$ els homes per a obtenir llicències i prestacions de maternitat o paternitat; promoure la distribució de les responsabilitats de l'home i la dona respecte de la família en peu d'igualtat, fins i tot per mitjà de lleis, incentius o estímuls apropiats, i promoure, a més, que es facilite la lactància a les mares treballadores.

b) Elaborar polítiques, entre altres coses, en l'esfera de l'ensenyament, per a modificar les aptituds que reforcen la divisió del treball sobre la base del gènere, a fi de promoure el concepte de les responsabilitats familiars compartides pel que fa al treball domèstic, en particular quant a l'atenció dels xiquets i els ancians.

Aquests dos punts inclosos en el Pla d'Actuació de la Conferència de Pequín van comportar que la Unió Europea incloguera en la

24. http://www.un.org/womenwatch/daw/Pequín/pdf/BDPfA\%20S.pdf. Consultat el 18 de desembre de 2013. 
seua normativa directives en referència a aquest tema anteriorment no considerat.

Fent un poc d'història, l'article 119 del Tractat de Roma, inici de la Comunitat Econòmica Europea, proclamava el principi d'igualtat retributiva entre homes i dones en cas de treballs del mateix valor.

Anys més tard, Jaques Delors, en el document titulat «Creixement, competitivitat i ocupació. Reptes i pistes per a entrar en el segle XXI», el 1993, més conegut com a «Llibre blanc», va presentar el paper de la dona treballadora com un recurs fonamental per a la millora de la competitivitat de l'economia europea.

Aquest moment va suposar un punt d'inflexió a partir del qual les mesures dirigides a l'increment de la taxa d'ocupació femenina han tingut un lloc central en les polítiques de treball de tots els governs membres.

Si bé, i com es va apuntar des de distints fòrums feministes, aquests objectius se centraven més en la incorporació de les dones al mercat laboral com a objectiu econòmic i no com a objectiu d'igualtat entre els gèneres, ja que tampoc es feia referència a la coresponsabilitat de les tasques domèstiques i d'atenció entre dones i homes.

Després de la celebració de la Conferència Mundial de Dones de Pequín s'aprova la Directiva 96/34/CE18 del Consell, de 3 de juny de $1996,{ }^{25}$ relativa a l'Acord marc sobre el permís parental celebrat per la UNICE, el CEEP i la CES. Aquesta directiva ha sigut considerada una de les normes que més directament ha contribuït a la conciliació de la vida personal, laboral i familiar, encara que fonamental i quasi en exclusiva pel que fa a la cura dels fills i filles.

Tant el preàmbul de l'Acord com l'apartat primer de la clàusula 1 sostenen que l'objectiu és «facilitar la conciliació de les responsabilitats professionals i familiars dels pares que treballen».

Després del Tractat d'Amsterdam (1999) s'albira un caràcter més ampli de les mesures i accions adoptades en matèria de conciliació de

25. Diari Oficial de les Comunitats Europees, núm. L 145/1, de 19 de juny de 1996. 
la vida personal, laboral i familiar, no obstant això, a través de l'anàlisi que a continuació s'exposa es pot comprovar com encara avui perdura el caràcter originari i econòmic de la Unió.

Com a instrument jurídic fonamental que naix dins d'aquest període, cal mencionar la Carta de Drets Fonamentals de la Unió Europea, de 7 de desembre de 2000, en l'article 33 de la qual es reconeix el dret a conciliar la vida personal, familiar i laboral.

Al desembre de 2009 entra en vigor el Tractat de Lisboa, que inclou en l'article 15: «En la definició i execució de les seues polítiques i accions, la Unió tractarà de lluitar contra tota discriminació per raó de sexe, raça o origen ètnic, religió o conviccions, discapacitat, edat o orientació sexual»».

Respecte a la normativa vinculant sorgida en aquesta etapa, és necessari ressaltar la Directiva 97/81/CE21 del Consell, de 15 de desembre de 1997, relativa a l'Acord marc sobre treball a temps parcial conclòs per UNICE, el CEEP i la CES.

El treball a temps parcial ha sigut considerat durant molt de temps com una de les modalitats d'ocupació que millor facilita la conciliació de la vida personal, familiar i laboral, i així queda disposat en la cinquena consideració general de l'Acord marc sobre el treball a temps parcial conclòs per la UNICE, el CEEP i la CES. No obstant això, estudis més recents han demostrat que aquesta modalitat d'ocupació té efectes negatius sobre la igualtat d'oportunitats entre homes i dones.

Després de l'anàlisi realitzada sobre la normativa de la Unió Europea més rellevant en matèria de conciliació de la vida personal, familiar i laboral, pot sostenir-se que pràcticament la totalitat dels textos estudiats presenten una finalitat econòmica darrere de l'aparent objectiu social que persegueixen i pretenen en primera instància.

En aquest sentit, Rossilli (2001) exposa que la política sobre igualtat de tracte i d'oportunitats entre dones i homes, així com la immensa majoria de polítiques socials de la Unió Europea, actua únicament amb un objecte clarament econòmic, és a dir, es limita al disseny de 
mesures conduents a la creació del mercat comú i a la reestructuració dels mercats laborals.

La dita afirmació es compleix també en el cas de les mesures dirigides a facilitar la conciliació de la vida laboral i familiar. Darrere d'aquestes es perseguixen fins com ara el creixement de la taxa d'activitat femenina o la construcció d'un mercat interior competitiu.

Juntament amb l'aprovació de directives, la Unió Europea ha implementat polítiques d'igualtat que inclouen referències a la conciliació entre la vida familiar i la vida laboral. Exposarem a continuació una breu referència als tres últims plans elaborats:

a) Estratègia marc sobre la igualtat entre homes i dones (20012005)

L'objectiu fonamental d'aquesta estratègia consisteix a establir un marc d'actuació que permeta integrar la qüestió de la igualtat en totes les activitats comunitàries, de manera que aquestes ajuden a aconseguir l'objectiu d'eliminar les desigualtats i promoure la igualtat entre homes i dones.

El text s'articula al voltant de cinc àmbits d'intervenció interdependents: la vida econòmica, la igualtat de participació i representació, els drets socials, la vida civil i els rols i estereotips masculins i femenins.

Si bé no s'inclou cap àmbit referit concretament a la conciliació entre la vida familiar i la vida laboral, sí que es té en compte en el contingut dels diferents àmbits com especifiquem a continuació:

- Promoure la igualtat de les dones i els homes en la vida econòmica.

El Consell Europeu de Lisboa de març de 2000 va invitar la Comissió i els Estats membres a promoure tots els aspectes de la igualtat d'oportunitats en les polítiques d'ocupació, 
entre altres coses reduint la segregació professional i fent més fàcil conciliar la vida laboral amb la vida familiar.

- Promoure la igualtat d'accés i el ple gaudi dels drets socials per a les dones i els homes.

La igualtat d'accés de les dones i el ple gaudi dels drets socials formen part dels fonaments de tota societat democràtica. A pesar de tot, moltes dones no gaudeixen d'aquesta igualtat d'accés als drets socials perquè alguns dels seus drets continuen estan basats en el model masculí del suport familiar, sense tenir en compte que les dones suporten una part preponderant de la càrrega que suposa conciliar la vida familiar i la professional. Molts sistemes de protecció social reflecteixen la persistència d'aquest model obsolet

En aquest Pla es visibilitza i es fa present el fet de la conciliació així com la major càrrega que suposa per a les dones en relació amb la divisió sexual del treball i el tradicional sistema de rols, però no es proposen normes d'actuació específiques per a combatre'l.

b) El Pla de treball per a la igualtat entre dones i homes (20062010)

E1 Pla de treball recolza els objectius del programa europeu per a la igualtat entre homes i dones i és la continuació de l'Estratègia marc sobre la igualtat entre homes i dones (2001-2005) a què anteriorment ens hem referit.

Comprèn sis àrees de treball, incloent-hi una específica relacionada amb la conciliació de la vida privada i l'activitat professional. S'hi inclouen els punts següents:

1. Els acords laborals flexibles impliquen una sèrie d'avantatges per als empleats i els ocupadors. No obstant això, les dones recorren més sovint a les disposicions de la política de conciliació, la qual cosa pot tenir conseqüències negati- 
ves per a la posició professional d'aquestes en el seu lloc de treball i per a la seua independència econòmica.

2. La UE s'enfronta al declivi demogràfic i a l'envelliment de la seua població, la qual cosa afecta el mercat laboral. És essencial facilitar l'accés a les guarderies i l'equilibri entre el treball i la vida privada, i millorar les prestacions de serveis destinats a les persones grans.

3. Haurien d'adoptar-se mesures per a animar els homes a gaudir del permís de paternitat o treballar a mitja jornada.

En aquests tres punts contemplats s'evidencien les qüestions següents: en primer lloc, les mesures de conciliació poden tenir conseqüències negatives en les dones si són les úniques usuàries de les dites mesures, ja que afectaran la seua remuneració econòmica, la seua promoció laboral i la seua futura jubilació, per la qual cosa la desigualtat entre homes i dones no es veu disminuïda.

En segon lloc, s'al·ludeix a la intervenció de l'Estat en la facilitació de la conciliació amb la creació de guarderies i de serveis per a persones grans. Aquesta actuació es relacionaria amb la intervenció desfamiliaritzadora de l'Estat (Campillo, 2010), però la situació de crisi actual paralitza qualsevol intervenció de l'Estat en aquest sentit, més aviat es torna a una situació familiaritzadora dels temes d'atenció, en la qual les dones són les principals protagonistes.

En tercer lloc, el condicional «haurien d'adoptar-se mesures» xoca amb les dades reals sobre quin membre de la parella gaudeix del permís de maternitat/paternitat o sol-licita la reducció de jornada. Segons dades de Mujeres en cifras (Institut de la Dona, 2014), la crisi econòmica i la persistència dels rols $\mathrm{i}$ estereotips tradicionals porta al fet que siguen predominantment les dones les que sol-liciten les baixes i les reduccions horàries, i es relaciona en aquest últim cas amb el que s'ha comentat anteriorment. 
c) Estratègia per a la igualtat entre dones i homes (2010-2015) Aquesta és l'estratègia que actualment està en vigor. En la seua introducció s'inclou el text següent:

Les desigualtats entre dones i homes violen drets fonamentals. A més, imposen una pesada càrrega a l'economia i suposen un balafiament de talents. D'altra banda, promoure una major igualtat entre els sexes pot aportar avantatges econòmics i empresarials. Per a aconseguir els objectius d'Europa 2020, és a dir, un creixement intel-ligent, sostenible i integrador, és necessari utilitzar el potencial i els talents de les dones de manera més extensa i eficaç.

Els rols assignats als sexes continuen influint en decisions individuals crucials sobre qüestions d'educació, carrera professional, organització del treball, família i fertilitat. Al seu torn, aquestes decisions tenen un impacte en l'economia i la societat. Per tant, per a tots és positiu que s'oferisquen autèntiques opcions, tant als homes com a les dones, al llarg de les distintes fases de les seues vides.

Sobre la base del Pla de treball per a la igualtat entre les dones i els homes (2006-2010), així com del Pacte europeu per la igualtat de gènere, l'Estratègia detalla accions d'acord amb cinc àrees prioritàries i unes qüestions horitzontals: la mateixa independència econòmica; salari igual a treball igual i del mateix valor; igualtat en la presa de decisions; dignitat, integritat i fi de la violència sexista; igualtat en l'acció exterior; qüestions horitzontals.

No hi ha referència expressa a la conciliació entre la vida laboral i familiar però s'inclouen al·lusions a aquest àmbit en dues de les àrees comentades.

- La mateixa independència econòmica

El text fa referència al fet que la independència econòmica és un requisit previ perquè les dones i els homes puguen controlar les seues vides i tinguen autèntica llibertat per a triar.

Per a això, l'objectiu europeu 2020 vol assolir una taxa d'ocupació del $75 \%$ per a les dones, prestant especial atenció a la participació 
de dones de més edat, persones soles amb fills, discapacitades, immigrants i dones pertanyents a minories ètniques.

Ara bé, perquè això siga possible és necessari tenir en compte que l'impacte dels fills i filles en la participació en el mercat laboral és molt diferent per a les dones i per als homes, perquè les dones continuen portant sobre els muscles una part desproporcionada de les responsabilitats que entranya la vida d'una família, incloent-hi també les tasques d'atenció a persones dependents ateses les actuals tendències demogràfiques d'envelliment de la població en la nostra societat.

El text apunta que en els Estats membres que han adoptat polítiques de conciliació, el nombre de dones i homes que treballen és alt, i els índexs de natalitat són relativament sostenibles.

S'inclou també una referència al fet que la Comissió perseguirà nous progressos en aquest camp, prestant especial atenció a la disponibilitat de cures assequibles i d'alta qualitat.

- Qüestions horitzontals

En aquesta àrea s'incorpora el punt «Rols en funció del sexe» el contingut del qual inclou que l'atribució a homes i dones de rols tradicionals rígids pot restringir les opcions individuals i limitar el potencial dels uns i les altres. Per això, una contribució essencial en pro de la igualtat és fomentar els rols no discriminatoris en tots els àmbits de la vida, com ara l'educació, la promoció professional, l'ocupació o l'esport. 


\section{CAPÍTOL II \\ LA REGULACIÓ DELS DRETS \\ DE CONCILIACIÓ A LA UNIVERSITAT \\ JAUME I}

\section{INTRODUCCIÓ}

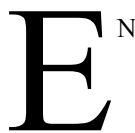

N EL PRESENT CAPÍTOL ${ }^{26}$ es revisa el contingut de les principals mesures de conciliació incloses en l'Enquesta sobre percepció i necessitats de conciliació de la vida familiar i laboral de la plantilla de la Universitat Jaume I, bàsicament amb una finalitat descriptiva. Cal subratllar que les mesures previstes en casos de violència de gènere es revisen en un apartat diferent perquè no estan destinades tant a la conciliació de la vida familiar i laboral, sinó més aviat a garantir i protegir la vida i la integritat física i moral de les dones víctimes de violència de gènere. ${ }^{27}$

Com s'ha advertit encertadament, l'anàlisi dels drets de conciliació en l'àmbit universitari resulta especialment dificultós a causa de la complexitat que caracteritza el marc normatiu d'aplicació (Argüelles Blanco, 2011). La regulació està formada per tres conjunts normatius diferents $-\mathrm{i}$ no sempre ben harmonitzats- $-{ }^{28}$ les normes generals d'aplicació tant

26. El present capítol s'ha elaborat en el marc del projecte d'investigació titulat «Negociació col-lectiva i igualtat efectiva a la Comunitat Valenciana. Una anàlisi jurídica i pràctica dels plans d'igualtat en les empreses», finançat per la Fundació Caixa Castelló-Bancaixa (2012-2014).

27. Cfr. articles 21 a 26 i disposicions addicionals 7 a 9 de Llei orgànica 1/2004, de 28 de desembre, de mesures per a la protecció integral contra la violència de gènere (BOE del 29).

28. En matèria de drets de conciliació, la sentència del Tribunal Suprem (Sala Social) de 19 de maig de 2009 (rec. cas. 97/2008), va estimar que el permís de paternitat previst en l'article 49 EBEP està reservat exclusivament per al personal funcionari, mentre que el personal laboral ha d'acudir a l'article 48 bis TRET, i no hi ha diferències apreciables entre ambdues normes (FFJ $3 \mathrm{i}$ 4). En el mateix sentit, la sentència del mateix Tribunal (Sala Social), de 14 de juny de 2010 (rec. 
estatals (p. e., Llei orgànica 3/2007, de 22 de març, per a la igualtat efectiva de dones i homes) com autonòmiques (p. e., Llei 9/2003, de 2 d'abril, de la Generalitat, per a la igualtat entre dones i homes); les normes d'àmbit universitari (Llei orgànica 6/2001, de 21 de desembre, d'universitats; Decret 116/2010, de 27 d'agost, del Consell, pel qual s'aproven els Estatuts de la Universitat Jaume I de Castelló; I Pla d'Igualtat aprovat pel Consell de Govern de la Universitat Jaume I); i, en tercer lloc, les normes d'ordenació del personal empleat públic, laboral (Estatut dels treballadors, convenis col-lectius) o funcionari (Estatut bàsic de l'empleat públic, Llei de la funció pública de la Comunitat Valenciana, acords col·lectius).

En particular, dins d'aquest últim conjunt normatiu, ha de tenir-se en compte que pot fer-se una clara divisió de la plantilla universitària, almenys en el cas de la Universitat Jaume I, en tres grups, atenent el règim jurídic que s'aplica en cada cas a l'exercici dels drets de conciliació: el personal docent $\mathrm{i}$ investigador contractat (a partir d'ara, PDI contractat), ${ }^{29}$ el professorat pertanyent als cossos docents universitaris

cas. 62/2009), va estimar que «cal interpretar que els arts. 47 a 50 EBEP estan dirigits essencialment als que ostenten la condició de funcionaris públics», de manera que no és possible el que s'ha denominat «l'espigueig normatiu», és a dir, l'aplicació al personal laboral de la norma més favorable en cada cas, «per a aconseguir la coexistència, per la sola voluntat d'una de les parts, de dues normatives distintes, triant en un concret extrem la més favorable, ara continguda en el text legal i no amb caràcter de dret necessari, i rebutjant aquells altres que no li resultarien tan beneficiosos de la normativa legal» (FJ 3).

29. Segons l'article 48.2 de la Llei orgànica 6/2001, de 21 de desembre, d'universitats (BOE del 24), el PDI contractat es correspon amb les figures d'ajudant, professor ajudant doctor, professor contractat doctor, professor associat i professor visitant, tenint en compte que també poden contractar personal investigador d'acord amb el que preveu la Llei 14/2011, d'1 de juny, de la ciència, la tecnologia i la innovació (48.3 bis). El règim del PDI contractat de les universitats serà establit per les comunitats autònomes en el marc de les seues competències, tenint en compte els termes establits en l'esmentada llei orgànica, que designa com a norma d'aplicació supletòria l'Estatut dels treballadors (48.2 i 6). A la Comunitat Valenciana el dit règim ha sigut desenvolupat pel Decret 174/2002, de 15 d'octubre, del Govern Valencià, sobre règim i retribucions del personal docent $\mathrm{i}$ investigador contractat laboral de les universitats públiques valencianes i sobre retribucions addicionals del professorat universitari (DOCV del 22), que en l'article 2.2 expressa que la contractació del personal docent i investigador té naturalesa de relació laboral especial i es regirà, entre altres, per la legislació de la Generalitat Valenciana aplicable al personal laboral al servei de les administracions públiques i per l'Estatut dels treballadors en allò no previst en la Llei orgànica 6/2001, de 21 de desembre, d'universitats, i en la mesura que no s'hi opose. No obstant 
(a partir d'ara, PDI funcionari) ${ }^{30} \mathrm{i}$, finalment, el personal d'administració i serveis, tant funcionari com laboral (a partir d'ara, PAs). ${ }^{31}$

\section{LA REGULACIÓ LEGAL DELS DRETS DE CONCILIACIÓ DE LA VIDA PERSONAL, FAMILIAR I PROFESSIONAL}

Els drets de conciliació de la vida personal, familiar i professional (a partir d'ara, els drets de conciliació) no apareixen enunciats de manera expressa en la Constitució espanyola (CE). La dimensió constitucional d'aquests s'ha construït jurisprudencialment amb base, en

això, el Decret 175/2006, de 24 de novembre, del Consell, pel qual es regulen les condicions de treball del personal al servici de l'administració (DOCV del 28), no hi resulta d'aplicació en la mesura que el seu àmbit se circumscriu el personal funcionari i laboral que preste els seus servicis en l'administració del Consell i els seus organismes autònoms (art. 1.1).

30. D'acord amb l'article 56.1 de la Llei orgànica 6/2001, citada, el professorat dels cossos docents universitaris ha de pertànyer al cos de catedràtics d'universitat $i$ de professors titulars d'universitat. L'apartat 56.2 estableix que el professorat funcionari es regirà per la legislació general de funcionaris que se li aplique, la qual cosa remet a la Llei 7/2007, de 12 d'abril, de l'Estatut bàsic de l'empleat públic (BOE del 13) (a partir d'ara, EBEP), l'article 2.2 de la qual inclou les universitats públiques dins del seu àmbit d'aplicació.

31. De conformitat amb l'article 73.1 de la Llei orgànica 6/2001, citada, el personal d'administració i serveis estarà format per personal funcionari de les escales de les mateixes universitats i personal laboral contractat per la mateixa universitat, així com per personal funcionari pertanyent als cossos i escales d'altres administracions públiques. D'acord amb l'article 3.1.b) de la Llei 10/2010, de 9 de juliol, de la funció pública de la Comunitat Valenciana (Docv del 14), el personal funcionari que exerceix funcions d'administració i serveis de les universitats pública de la Comunitat Valenciana es troba dins del seu àmbit d'aplicació. En matèria de jornada de treball, permisos, llicències i vacacions s'aplica al personal contractat que exerceix tals funcions el règim previst en el títol VI del mateix text legal, en la seua normativa de desplegament i en la legislació laboral corresponent, incloent-hi el conveni col-lectiu d'aplicació. En particular, a la Universitat Jaume I aquestes disposicions es desenvolupen en el Calendari laboral del personal d'administració i serveis, aprovat anualment pel Consell de Govern, que per a l'any 2014 és d'aplicació l'aprovat el 10 de desembre de 2013. No resulta d'aplicació al personal d'administració i serveis el Decret 175/2006, de 24 de novembre, citat, ja que el seu àmbit se circumscriu el personal funcionari i laboral que preste els seus servicis en l'administració del Consell i els seus organismes autònoms (art. 1.1), com ja s'ha vist. 
primer lloc, en la interdicció de tota discriminació per raó de sexe (art. 14 CE) (SSTC 128/1987, de 16 de juliol, i 166/1988, de 26 de setembre); en segon lloc, en el mandat de protecció de la família i la infància (art. $39 \mathrm{CE}$ ) (SSTC 3/2007, de 15 de gener, i 24/2011, de 14 de març); i, en tercer lloc, més recentment, en la prohibició de la discriminació per raó de circumstàncies familiars, quan qui exerceix els drets de conciliació és un home (STC 26/2011, de 14 de març).

Els estatuts d'autonomia elaborats després de l'aprovació de la Constitució tampoc van recollir previsions respecte d'això. Aquest panorama legal va romandre invariat en seu estatutària -no així en seu legislativa amb les successives lleis autonòmiques d'igualtat- ${ }^{32}$ fins a les reformes practicades des de 1'any 2006. ${ }^{33}$ Com ha afirmat J. Sevi1la Merino $(2008,54)$, «els nous Estatuts demostren en alguna part de la seua redacció una sensibilitat a favor dels drets de les dones, totalment ignorats en les redaccions de la primera etapa...». En efecte, si l'atenció se centra en els drets de conciliació, els estatuts d'autonomia

32. Llei 9/2003, de 2 d'abril, de la Generalitat Valenciana, per a la igualtat entre dones i homes (DOCV del 4), Llei 7/2004, de 16 de juliol, gallega per a la igualtat de dones i homes (DOG de 3 d'agost), Llei 4/2005, de 18 de febrer, per a la igualtat de dones i homes en el País Basc (BOPV de 2 de març), Llei 12/2006, de 20 de setembre, per a la dona de les Illes Balears (BоIвB del 26), Llei 2/2007, de 28 de març, del treball en igualtat de les dones de Galícia (DOG de 13 d'abril), Llei $7 / 2007$, de 4 d'abril, per a la igualtat entre dones i homes, i de protecció contra la violència de gènere de la Regió de Múrcia (BORM del 21), Llei 12/2007, de 26 de novembre, per a la promoció de la igualtat de gènere a Andalusia (волA de 18 de desembre). Després de les reformes estatutàries, Llei 1/2010, de 26 de febrer, canària d'igualtat entre dones i homes (BOCAN de 5 de març), Llei 12/2010, de 18 de novembre, d'igualtat entre dones i homes de Castella-La Manxa (DocLm del 25), Llei del Principat d'Astúries 2/2011, d'11 de març, per a la igualtat de dones i homes i l'eradicació de la violència de gènere (BOPA del 18) i Llei 8/2011, de 23 de març, d'igualtat entre dones i homes i contra la violència de gènere a Extremadura (DOE del 25).

33. Llei orgànica 1/2006, de 10 d'abril, de reforma de la Llei orgànica 5/1982, d'1 de juliol, d'Estatut d'Autonomia de la Comunitat Valenciana (воE de 1'11), Llei orgànica 6/2006, de 19 de juliol, de reforma de l'Estatut d'Autonomia de Catalunya (BOE del 20), Llei orgànica 1/2007, de 28 de febrer, de reforma de l'Estatut d'Autonomia de les Illes Balears (BOE d'1 de març), art. 61.2 de la Llei orgànica 2/2007, de 19 de març, de reforma de l'Estatut d'Autonomia per a Andalusia (BOE del 20), la Llei orgànica 5/2007, de 20 d'abril, de reforma de l'Estatut d'Autonomia d'Aragó (BOE del 23), Llei orgànica 14/2007, de 30 de novembre, de reforma de l'Estatut d'Autonomia de Castella i Lleó (воE d'1 de desembre) i Llei orgànica 1/2011, de 28 de gener, de reforma de l'Estatut d'Autonomia de la Comunitat Autònoma d'Extremadura (BOE del 29). 
reformats més recentment inclouen una referència expressa en aquesta matèria, excepte en el cas de l'Estatut d'Extremadura.

En l'Estatut de la Comunitat Valenciana es regula la «compatibilitat de la vida familiar i laboral» com a instrument perquè les dones i els homes puguen participar plenament en la vida laboral, social, familiar i política sense discriminació i per a garantir que ho facen en igualtat de condicions (art. 11); s'enuncia com a competència de la Generalitat garantir a totes les persones «un treball digne... que permeta la conciliació de la vida laboral i familiar...» (art. 80.1), preveient amb tal finalitat la garantia del dret a la protecció legal enfront de l'acomiadament motivat per la maternitat, un permís retribuït per raó de maternitat $i$ un permís parental per naixement o adopció de fill (art. 80.3).

En el text estatutari de les Illes Balears es conceptua la conciliació de la vida familiar i laboral en termes pràcticament idèntics al text de la Comunitat Valenciana, això és, com a instrument per a la plena participació de dones i homes en la vida laboral i familiar en condicions d'igualtat (art.17); i s'enuncia més endavant com a competència exclusiva relacionada amb la protecció social de la família (art. 30.16).

En l'Estatut d'Autonomia de Catalunya la conciliació de la vida laboral i familiar està prevista com una mesura de suport a les famílies que ha de ser promoguda pels poders públics (art. 40.2), advertint posteriorment que tals poders han de reconèixer i tenir en compte el valor econòmic del treball d'atenció i cures en l'àmbit domèstic i familiar en la fixació de les seues polítiques econòmiques i socials (art. 41.4).

El text estatutari aragonès, al seu torn, regula la conciliació de la vida familiar i laboral entre les matèries relacionades amb l'ocupació i el treball que els poders públics d'Aragó han de promoure (art. 26).

En l'Estatut de Castella i Lleó la conciliació apareix novament regulada, com en els casos català i balear, com a instrument per a la protecció de la família, que es converteix en principi rector de les polítiques públiques de Castella i Lleó. 
L'anàlisi dels estatuts d'autonomia reformats des de l'any 2006 mostra, d'una banda, que no es produeix una regulació tant dels drets de conciliació -que podria haver-se dut a terme en la mesura que una de les característiques dels nous estatuts d'autonomia ha sigut, precisament, la incorporació d'un elenc més o menys ampli de drets subjectius- quant de la matèria «conciliació» com un instrument o mecanisme que ha de ser promogut en un binomi format pel dret al treball en igualtat d'oportunitats de dones i homes i la protecció de la família; i, d'altra banda, que no s'ha seguit la conceptuació i la nomenclatura expressada per la Llei orgànica $3 / 2007$, de 22 de març, per a la igualtat efectiva de dones i homes, a pesar de ser anterior en el temps, que es refereix als drets de conciliació de la vida personal, familiar i laboral -en línia amb la normativa comunitària més recent sobre aquesta qüestió-, sinó que es manté la terminologia emprada en la Llei 39/1999, de 5 de novembre, per a promoure la conciliació de la vida familiar i laboral de les persones treballadores, deixant de costat la conciliació de la vida personal.

En el pla legal -sense perjudici de les millores introduïdes per la Llei 3/1989, de 3 de març, que va ampliar a setze setmanes el permís de maternitat, va tornar transferible al pare una part de la suspensió per maternitat i va establir altres mesures per a afavorir la igualtat de tracte de la dona en el treball (вов del 8); i, més tard, per la Llei 31/1995, de 8 de novembre, de prevenció de riscos laborals (BOE del 10), que va incorporar certes previsions en matèria de seguretat i salut de les treballadores embarassades, parteres i lactants-, la primera norma legislativa que va tractar aquesta qüestió de manera monogràfica va ser la Llei 39/1999, de 5 de novembre, per a promoure la conciliació de la vida familiar i laboral de les persones treballadores (воE del 6). Aquesta llei va incorporar a l'ordenament jurídic espanyol la Directiva 96/34/CE, de 3 de juny, relativa a l'Acord marc sobre el permís parental celebrat per la UNICE, el CEEP i la CES (DOCE L 145, del 19). Si bé el text legal va suscitar certes crítiques doctrinals (Ballester Pastor, 2000), va introduir-hi millores substantives com ara nous supòsits de permís retribuït per raons 
familiars, el dret a reduir la jornada o a obtenir una excedència pels mateixos motius, l'ampliació del període no obligatori de suspensió per maternitat transferible al pare, la inhibició de les absències causades per motius de conciliació com a causa d'acomiadament objectiu i la nul-litat radical de la decisió extintiva contractual en supòsits d'embaràs, maternitat, adopció, acolliment o exercici de certs drets de conciliació.

Encara que diverses normes legals posteriors van introduir alguna mesura en matèria de conciliació - com ara la Llei 12/2001, de 9 de juliol, de mesures urgents de reforma del mercat de treball per a l'increment de l'ocupació i la millora de la seua qualitat (BOE del 10), en relació amb la duració del permís de maternitat en cas de fills prematurs o que requerisquen hospitalització després del part; o la Llei orgànica 1/2004, de 28 de desembre, de mesures de protecció integral contra la violència de gènere (BOE del 29), en matèria d'ordenació del temps de treball, mobilitat geogràfica, suspensió de la relació laboral i extinció del contracte de treball en el cas de dones víctimes de violència de gènere-, el següent text legal que incideix de manera excel-lent en els drets de conciliació és la Llei orgànica 3/2007, de 22 de març, per a la igualtat efectiva de dones i homes (вOE del 23) (a partir d'ara, LOI). La LOI marca una fita en matèria de conciliació fonamentalment per dos motius: en primer lloc, perquè aspira a convertir els drets de conciliació en un instrument al servei de la coresponsabilitat, en la mesura que han de reconèixer-se de manera que «fomenten l'assumpció equilibrada de les responsabilitats familiars, evitant tota discriminació basada en el seu exercici» (art. 44.1); i, en segon lloc, perquè crea el permís de paternitat -amb la seua corresponent prestació de Seguretat Social-, precisament per a contribuir a l'objectiu de «contribuir a un repartiment més equilibrat de les responsabilitats familiars» (art. 44.3). La LoI compta també amb altres mesures excel-lents que afecten els drets de conciliació, com ara la seua inclusió en el contingut dels nous plans d'igualtat (art. 46), la seua profusa regulació en el terreny de l'ocupació pública (arts. 51.b) i 56 i ss.) o la millora en el contingut d'alguna de les manifestacions dels drets de conciliació prèviament contemplats (reducció de jornada, excedències, lactància...). 
No obstant això, l'objectiu de convertir els drets de conciliació en instruments que repercutisquen en la coresponsabilitat queda limitat pràcticament al permís de paternitat, d'altra banda ampliat posteriorment de tretze dies a quatre setmanes per la Llei 9/2009, de 6 d'octubre, d'ampliació de la duració del permís de paternitat en els casos de naixement, adopció o acollida (BOE del 7), si bé d'una forma que podria denominar-se «virtual», en la mesura que l'entrada en vigor de tal ampliació va quedar postergada fins a l'1 de gener de 2011, i així successivament $\mathrm{i}$ ininterrompudament des d'aqueixa data en cada anualitat fins a l'assenyalada actualment, l'1 de gener de 2015, acumulant un total de quatre anys de vacatio legis. A més, també cal assenyalar que alguna qüestió rellevant no incorporada en la LOI, com ara la titularitat masculina del permís per lactància, amb independència de la situació laboral de la mare, va haver de ser reformada posteriorment com a conseqüència de la sentència del Tribunal de Justícia de la Unió Europea, de 30 de setembre de 2010, en el cas Roca Álvarez.

L'última fita en la regulació dels drets de conciliació se situa en les reformes operades com a conseqüència de la crisi financera desencadenada l'any 2008, condensades en la reforma laboral de 2012 de manera especial. ${ }^{34} \mathrm{El}$ resultat de tals reformes no presenta un saldo positiu per al treball de les dones en general (Rodríguez Fernández, 2014), ni per al reconeixement i l'exercici dels drets de conciliació en particular (Jover Ramírez, 2013). Sense ànim d'exhaustivitat, dues modificacions legals permeten donar compte de les anteriors asseveracions. En primer lloc, la reducció de jornada per atenció a filles i fills i la resta de familiars (art. 37.5 TRET) s'havia configurat com un dret incondicional de la treballadora o treballador que, a més, podia triar la jornada de referència (diària, setmanal) sobre la qual operar la reducció. Després de la reforma laboral citada ha desaparegut la selecció de la jornada que es pot reduir, la qual queda restringida a la

34. Reial decret llei 3/2012, de 10 de febrer, de mesures urgents per a la reforma del mercat laboral (BOE de l'11); Llei 3/2012, de 6 de juliol, de mesures urgents per a la reforma del mercat laboral (BOE del 7). 
jornada diària, i, a més, el seu exercici queda condicionat als termes acordats en la negociació col·lectiva que siga aplicable (art. 37.5 TRET). En segon lloc, la conversió del conveni d'empresa en la unitat de negociació col·lectiva preferida pel legislador en determinades matèries -entre les quals, les mesures per a afavorir la conciliació entre la vida laboral, familiar i personal-, no facilita l'avanç en el dret al treball en igualtat d'oportunitats de dones i homes ni, menys encara, en la conciliació o la coresponsabilitat. A aquest respecte, s'ha evidenciat que la descentralització de la negociació col·lectiva dóna lloc a resultats menys equitatius en les condicions laborals de les dones (Van Wanrooy, 2009); en el mateix sentit, la negociació de la igualtat salarial està més present en els sistemes de negociació centralitzats (Heery 2006). En conseqüència, la preferència pel conveni d'empresa en matèries com ara la determinació del salari base i els complements salarials, l'horari i la distribució del temps de treball o les mesures de conciliació no pareix afavorir l'avanç en la igualtat laboral de dones i homes, sinó tot al contrari.

Per a saber-ne més:

$\mathbb{\square}$ Romero Burillo, A. M.; Moreno Gené, J. (coords.) (2010): El personal docente e investigador laboral de las universidades públicas: aspectos legales y negociación colectiva, Bomarzo, Albacete.

\subsection{PERMÍS PER A LA REALITZACIÓ D'EXÀMENS PRENATALS I TÈCNIQUES DE PREPARACIÓ AL PART}

Règim jurídic: art. 37.3.f) TRET; art. 48.e) EBEP; art. 69.1.b) i d) Llei 10/2010; art. 10.5 Calendari laboral del PAs per a l'any 2014.

Les treballadores i les funcionàries embarassades compten amb un permís retribuït quan hagen de realitzar exàmens prenatals o formar-se en tècniques de preparació al part durant la jornada de treball. Mentre el primer supòsit està destinat a controlar tant l'adequat desenvolupament 
de la gestació (p. e., tècniques ecogràfiques, proves de biòpsia corial o amniocentesi, etc.) com la salut de la mare gestant (p. e., consulta en els serveis de tocoginecologia), el segon es dirigeix a facilitar que aquesta s'instruïsca en les tècniques que haurà d'emprar en les distintes fases del part (p. e., cursos o tallers de preparació al part). En canvi, aquesta previsió no inclou els reconeixements mèdics ordinaris motivats per altres circumstàncies -que compten amb la seua regulació específica, segons s'exposa en l'apartat 3.2-. L'exercici d'aquest permís requereix el seu avís i justificació previs, sense que siga necessària la concessió expressa del permís per part de l'empresari en el cas del PDI contractat.

Aquest permís només pot ser exercit per les treballadores o funcionàries embarassades. En algun cas el pare ha sol-licitat exercir aquest permís per a acudir als cursos preparatoris al part amb la mare, en la mesura que el TRET no identifica com a destinatàries exclusives de la norma les mares gestants -a diferència de l'EBEP, que parla expressament de «les funcionàries embarassades», i del Calendari laboral del PAs per a l'any 2014, que es refereix a «la dona treballadora»-, la qual cosa pretenia servir de justificació perquè els (barons) treballadors pogueren exercir-lo igualment. Aquesta interpretació ha sigut rebutjada pels tribunals perquè la norma que va incorporar aquest permís a l'ordenament laboral porta causa de l'article 26.4 de la Llei de prevenció de riscos laborals, abans citada, que contempla el dret de «les treballadores embarassades» a aquest permís, així com, en últim terme, de la Directiva 92/85/CEE, del Consell, de 19 d'octubre, que es titula precisament «Aplicació de mesures per a promoure la millora de la seguretat i de la salut en el treball de la treballadora embarassada, que haja donat a llum o en període de lactància» (STSJ d'Andalusia 1431/2007, de 23 abril, rec. sup. 599/2006).

El PAs compta a més amb un permís per a la realització de tractaments de fecundació assistida ${ }^{35} \mathrm{o}$ en cas d'interrupció de l'embaràs.

35. D'acord amb l'apartat 8.4 de la Resolució de 28 de desembre de 2012, de la Secretaria d'Estat d'Administracions Públiques, per la qual es dicten instruccions sobre jornada i horaris de treball del personal al servei de l'Administració General de l'Estat i els seus organismes públics (воE del 29), els empleats públics també poden absentar-se del treball per a sotmetre's a tècniques de fecundació o reproducció assistida. 
En aquest segon supòsit, la treballadora o funcionària del PAs té, a més, dret a un permís de sis dies naturals i consecutius, sempre que no es trobe en situació d'incapacitat temporal, comptador des del dia d'interrupció de l'embaràs.

Per a saber-ne més:

$\Delta \backslash$ Sentència 1431/2007, de 23 d'abril, del Tribunal Superior de Justícia d’Andalusia (Sala Social) (rec. sup. 599/2006).

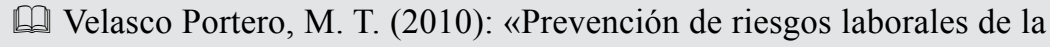
mujer embarazada y en periodo de lactancia»: Gestión práctica de riesgos laborales: Integración y desarrollo de la gestión de la prevención, n. 68: 22-27.

\subsection{PERMÍS PER PART O MATERNITAT}

Règim jurídic: arts. 45.1.d) i 48.4 TRET; art 49.a) EBEP; art. 69.3.a) Llei 10/2010; art. 10.7 del Calendari laboral del PAs per a l'any 2014.

La maternitat és una de les causes que permet la suspensió del contracte de treball. El contingut del dret de conciliació a què dóna lloc compta amb una naturalesa mixta, que va servir inicialment per a preservar la seguretat i la salut de la dona treballadora després de l'infantament, però que amb el pas del temps s'ha instrumentat en certa manera com un dret de conciliació.

En aquest sentit, la titularitat del permís per maternitat correspon a la mare, però és transferible, això és, pot ser gaudit per l'altre progenitor en tres supòsits:

- Per voluntat de la mare, en el cas que ambdós progenitors treballen. Aquesta opció ha d'exercitar-se a l'inici del descans -si bé hi ha la possibilitat de revocar-lo davant de certs fets sobrevinguts (p. e., accident, defunció, separació de l'altre progenitor)-, de tal manera que l'altre progenitor gaudisca d'una part determinada i ininterrompuda de la suspensió posterior al part, 
ja siga de forma simultània amb la mare, o de forma successiva a ella -però sense poder afectar en cap cas el descans obligatori corresponent a les sis setmanes immediatament posteriors al part-. El fet que la mare es trobe en situació d'incapacitat temporal en el moment de reincorporar-se al treball no anul·la o modifica el període de suspensió cedit per al gaudi de l'altre progenitor. Quan el gaudi del descans siga simultani per part dels dos progenitors, la suma dels dos períodes de suspensió no podrà excedir les setze setmanes o les addicionals que corresponguen en cas de part múltiple o de discapacitat del fill.

- Per defunció de la mare, amb independència que realitzara o no algun treball retribuït. L'altre progenitor pot fer ús de la totalitat del període de suspensió. Si la mare haguera consumit una part de la seua duració després del part, l'altre progenitor podrà gaudir del període de suspensió que reste, de tal manera que en aquest supòsit no es descomptarà la part de suspensió consumida per la mare amb anterioritat al part.

- Perquè la mare no compleix els requisits per a ser beneficiària de la prestació per maternitat, d'acord amb els articles $133 \mathrm{ter}$ i 133 sexies de la Llei general de la Seguretat Social. En aquest supòsit l'altre progenitor té dret a suspendre el seu contracte de treball pel període que li hauria correspost a la mare, resultant a més compatible aquesta suspensió amb la corresponent a la paternitat.

La duració de la suspensió per maternitat és, amb caràcter general, de setze setmanes ininterrompudes, de les quals sis han d'efectuar-se en les setmanes immediatament posteriors al part. La resta del període de suspensió es distribuirà a opció de la interessada. ${ }^{36}$ En el supòsit de part múltiple, la duració s'ampliarà en dues setmanes més per cada fill

36. D'acord amb el Calendari laboral per a l'any 2014, el PAs pot acumular aquest permís a les vacances anuals i al permís per lactància, encara que haja expirat ja l'any natural a què corresponguen (art. 10.7). 
a partir del segon. En el cas que el nadó tinga una discapacitat-que es xifra reglamentàriament en un grau igual o superior al 33 per centla duració s'ampliarà en dues setmanes més novament. En el cas de defunció del fill, el període de suspensió romandrà inalterat, llevat que la mare sol·licite la seua reincorporació abans que finalitze, però en tot cas una vegada consumides les sis setmanes de descans obligatori anteriorment referides. ${ }^{37}$

El còmput del període de suspensió compta amb un règim especial en els casos de part prematur i en aquells que, per qualsevol altra causa, el nounat haja de romandre hospitalitzat a continuació del part -sempre excloent-ne les sis setmanes de descans obligatori immediatament després del part-. En aquests supòsits la mare o, si no n'hi ha, l'altre progenitor pot instar -es tracta d'una facultat- que el còmput no comence en la data de l'infantament, sinó que ho faça en la data de l'alta hospitalària.

Al mateix temps, però en aquest cas de manera imperativa, la duració del període de suspensió en els supòsits de part prematur amb falta de pes i d'altres en què el nounat necessite, per alguna condició clínica, hospitalització a continuació del part superior a set dies -incloent-hi els internaments hospitalaris iniciats durant els trenta dies naturals següents al part, segons el desplegament reglamentari que, en l'actualitat, es troba derogat-, s'ampliarà necessàriament en el mateix nombre de dies que el menor romanga hospitalitzat, amb un màxim de tretze setmanes addicionals, fins a completar un total de vint-i-nou setmanes.

La suspensió per maternitat pot gaudir-se en règim de jornada completa o a temps parcial. En el cas dels treballadors sotmesos a l'Estatut dels treballadors -el PDI contractat-, hi ha d'haver un acord amb l'empresari en aquest sentit; en el cas dels empleats públics -PDI funcionari i PAs-, les necessitats del servei han de permetre el seu gaudi en una

37. D'acord amb el Calendari laboral per a l'any 2014, en el supòsit d'avortament espontani en els tres últims mesos de gestació, la mare pertanyent al PAs tindrà dret al descans obligatori per maternitat de sis setmanes, sense que la seua renúncia done dret al pare a gaudir del permís. 
modalitat o en una altra. En el cas d'optar per gaudir el permís en jornades a temps parcial, han de tenir en compte dues qüestions: d'una banda, que el període de descans obligatori de sis setmanes immediatament posteriors al part és necessàriament a temps complet; i, d'una altra, que la duració del permís s'amplia proporcionalment segons l'extensió de la jornada a temps parcial triada.

Com que la maternitat no pot donar lloc a un tracte advers en les relacions laborals, mentre dóna lloc a una discriminació directa, qualsevol millora en les condicions de treball a què es tinguera dret esdevinguda durant el període de suspensió també beneficiarà els que exercisquen el dret de conciliació tractat en aquest apartat. De la mateixa manera, si el període de gaudi del permís per maternitat ha coincidit amb el de vacances, la treballadora podrà gaudir d'aquestes igualment en finalitzar el període de suspensió, fins i tot encara que haja finalitzat l'any natural a què corresponguen (art. 38.3 TRET).

El permís de maternitat, en tractar-se d'una suspensió del contracte de treball, exonera de les obligacions recíproques de treballar i remunerar el treball (art. 45.2 TRET). Per aquest motiu, els treballadors sotmesos a l'Estatut compten amb una prestació de la Seguretat Social, la quantia de la qual equival al cent per cent de la base reguladora corresponent i la duració de la qual s'estén al període de descans que es gaudisca. ${ }^{38}$

En canvi, el personal empleat públic no passa a una situació administrativa diferent per exercir el permís per maternitat, atès que es tracta d'un permís pròpiament dit. Per consegüent, té dret al fet que el temps transcorregut durant el gaudi d'aquest permís es compute com a temps de servei efectiu a tots els efectes $i$, en particular, de caràcter econòmic. L'empleada pública i, en cas de transferència, l'altre progenitor empleat públic, disposen d'una garantia de plenitud dels seus drets econòmics durant tota l'extensió temporal del permís, que s'es-

38. Capítol Iv bis de la Llei general de la Seguretat Social i Reial decret 295/2009, de 6 de març, pel qual es regulen les prestacions econòmiques del sistema de la Seguretat Social per maternitat, paternitat, risc durant l'embaràs i risc durant la lactància natural (вOE del 21). 
tén també als períodes posteriors a aquest en el cas que el dret a percebre algun complement retributiu es determine en funció del temps corresponent a l'exercici del permís, d'acord amb la normativa aplicable. Així mateix, durant el gaudi del permís es podrà participar en els cursos de formació que l'administració convoque. Una vegada finalitzat el permís per maternitat, tenen dret a reintegrar-se en el seu lloc de treball en els termes i condicions que no donen lloc a un tracte desfavorable derivat del gaudi del permís. També tenen dret a beneficiar-se de qualsevol millora en les condicions de treball a què haurien pogut tenir dret durant la seua absència. Aquest règim s'aplica en els mateixos termes en els supòsits de permís per paternitat, per adopció o acolliment (arts. 49.a), b) i c) EBEP).

Per a saber-ne més:

$\Delta \backslash$ Sentència 172/2013, de 30 de setembre, de l'Audiència Nacional (Sala Social) (AS 2013\2715).

[1] Garrigues Giménez, A. (2004): La maternidad y su consideración jurídico-laboral y de Seguridad Social, Comité Económico y Social, Madrid.

\subsection{PERMÍS PER ADOPCIÓ O ACOLLIMENT}

Règim jurídic: arts. 45.1.d), 48.4 i 48.bis TRET; art 49.b) EBEP; art. 69.3.b) Llei 20/2010; art. 10.11 del Calendari laboral del PAs per a l'any 2014.

Una nova causa de suspensió del contracte de treball ve donada per 1'adopció o l'acolliment, ${ }^{39}$ tant de menors de sis anys -edat a partir de la qual l'escolarització resulta obligatòria,,$-{ }^{40} \mathrm{com}$ de menors d'edat per damunt dels referits sis anys que siguen discapacitats o que per les seues circumstàncies, per les seues experiències personals o per pro-

39. El règim jurídic de l'adopció i l'acolliment de menors es troba en els articles 172 i ss. del Codi civil.

40. Art. 4.2 de la Llei orgànica 2/2006, de 3 de maig, d'educació (BOE del 4). 
venir de l'estranger, tinguen especials dificultats d'inserció social i familiar degudament acreditades pels serveis socials competents. ${ }^{41}$ En el cas de l'acolliment, siga preadoptiu, permanent o simple, i amb independència del seu caràcter provisional o definitiu, la seua duració ha de ser igual o superior a un any perquè done lloc a l'exercici d'aquest permís.

La titularitat d'aquest permís correspon indistintament tant a les treballadores o funcionàries com als treballadors o funcionaris. En el cas que ambdós progenitors treballen, el període de suspensió es distribuirà a opció dels interessats, i el podran exercir de forma simultània o successiva, però sempre de manera ininterrompuda, com també ocorre en els permisos de maternitat i paternitat, i amb el màxim de duració que s'indica a continuació. ${ }^{42}$

La duració del permís és de setze setmanes ininterrompudes. En el supòsit d'adopció o acolliment múltiples, la duració s'amplia en dues setmanes per cada menor a partir del segon. A més, si el menor adoptat o acollit és discapacitat, la suspensió del contracte de treball tindrà una duració addicional de dues setmanes, que poden ser gaudides per un dels progenitors o, si ambdós treballen, pels dos. En aquest segon supòsit, correspon als dos progenitors efectuar la dita opció i, novament, poden gaudir les setmanes addicionals de forma simultània o successiva, però sempre de manera ininterrompuda.

Ha de tenir-se en compte que, en el supòsit de gaudi simultani dels períodes de descans per part dels dos progenitors, la suma d'aquests no pot excedir el límit màxim indicat, això és, un total de setze setmanes o les setmanes addicionals que corresponguen en cas d'adopció o acolliment múltiples i en cas de menors amb discapacitat.

El permís per adopció o acolliment pot iniciar-se en dos moments diferents, a elecció del personal contractat o funcionari: a partir de la decisió administrativa o judicial d'acolliment, provisional o definitiu,

41. L'edat màxima no apareix concretada en el Calendari laboral del PAs per a l'any 2014 (art. 10.11 del Calendari laboral).

42. El Calendari laboral del PAs preveu que el cònjuge o parella de fet de la mare puga gaudir del permís per adopció o acolliment «prèvia renúncia del pare biològic» (art. 10.11). 
o a partir de la resolució judicial per la qual es constitueix l'adopció. La disjuntiva entre un moment o l'altre sorgeix perquè un mateix menor no dóna dret a diversos períodes de suspensió, per la qual cosa la suspensió pot exercitar-se de manera alternativa en un moment o en l'altre, però no en els dos de forma consecutiva. Hi ha un supòsit en què qui adopta o acull pot iniciar aquest permís fins a quatre setmanes abans de la resolució per la qual es constitueix l'adopció: en el cas d'adopcions internacionals en què siga necessari el desplaçament previ dels progenitors al país d'origen de l'adoptat. Davant del mateix supòsit, $\mathrm{i}$ amb independència de poder avançar el gaudi del permís fins a quatre setmanes, el PDI funcionari i el PAS comptarà amb un permís addicional de fins a dos mesos de duració, període durant el qual percebrà exclusivament les retribucions bàsiques.

La suspensió per adopció o acolliment pot gaudir-se en règim de jornada completa o a temps parcial. En el cas del PDI contractat hi ha d'haver un acord amb l'empresari en aquest sentit; en el cas del PDI funcionari o del PAs, les necessitats del servei han de permetre el seu gaudi en una modalitat o en l'altra. En el cas d'optar per gaudir el permís en jornades a temps parcial, han de tenir-se en compte que la duració del permís s'amplia proporcionalment segons l'extensió de la jornada a temps parcial triada.

Qualsevol millora en les condicions de treball a què es tinguera dret esdevinguda durant el període de suspensió també beneficiarà els que exercisquen el dret de conciliació tractat en aquest apartat. De la mateixa manera, si el període de gaudi del permís per adopció o acolliment ha coincidit amb el de vacances, la treballadora podrà gaudir d'aquestes igualment en finalitzar el període de suspensió, fins i tot encara que haja finalitzat l'any natural a què corresponguen (art. 38.3 TRET).

El permís per adopció o acolliment, en tractar-se d'una suspensió del contracte de treball, exonera de les obligacions recíproques de treballar i remunerar el treball (art. 45.2 TRET). Per aquest motiu, els treballadors sotmesos a l'Estatut compten amb una prestació de la Seguretat Social, la quantia de la qual equival al cent per cent de la base 
reguladora corresponent i la duració de la qual s'estén al període de descans que es gaudisca. ${ }^{43}$

El personal empleat públic compta amb una garantia de plenitud dels seus drets durant tota l'extensió temporal del permís, tal com s'ha desenvolupat en ocasió de l'anàlisi del permís per maternitat.

Per a saber-ne més:

$\Delta \Delta$ Sentència 342/2011, de 18 de maig, del Tribunal Superior de Justícia d’Aragó (Sala Social) (rec. sup. 260/2011) (AS 2011\1160).

미 Molina González-Pumariega, R. (2004): La protección jurídica de la mujer trabajadora, Consejo Económico y Social, Madrid.

\subsection{PERMÍS PER PATERNITAT}

Règim jurídic: arts. 45.1.d) i 48.bis TRET; art 49.c) EBEP; art. 69.3.c) Llei 10/2010; art. 10.10 Calendari laboral del PAs per a l'any 2014.

El permís per paternitat va ser la principal mesura introduïda per la LOI per a impulsar la coresponsabilitat. La paternitat es converteix en una nova causa que permet la suspensió del contracte de treball, en el cas del personal contractat, o el gaudi d'un permís, en el cas del personal empleat públic. Es tracta d'un dret de conciliació que, en el supòsit de part, la titularitat del qual correspon en exclusiva a l'altre progenitor. ${ }^{44}$ És, en conseqüència, intransferible, de manera que el seu gaudi no pot ser transferit a la mare. En canvi, en cas d'adopció o acolliment, el permís per paternitat correspon només a un dels dos progenitors, a la seua elecció; si bé en el cas que el permís per adopció o acolliment, tractat en l'apartat anterior, haja sigut exercit en la seua

43. Capítol Iv bis de la Llei general de la Seguretat Social i Reial Decret 295/2009, de 6 de març, pel qual es regulen les prestacions econòmiques del sistema de la Seguretat Social per maternitat, paternitat, risc durant l'embaràs i risc durant la lactància natural (BOE del 21).

44. En el cas del PAs, el Calendari laboral preveu que el cònjuge o parella de fet de la mare puga gaudir del permís per paternitat «prèvia renúncia del pare biològic» (art. 10.10). 
totalitat per un dels progenitors, el dret a la suspensió per paternitat únicament podrà ser exercit per l'altre progenitor.

La duració del permís per paternitat és de tretze dies ininterromputs per al PDI contractat. ${ }^{45}$ En el supòsit de part múltiple, la duració s'amplia en dos dies més per cada fill a partir del segon. El permís per paternitat pot gaudir-se en dos períodes diferents, a elecció del treballador:

- El que transcorre des de la finalització dels dos dies corresponents al permís per naixement de fill -quatre en el cas que el treballador haja de fer un desplaçament (art. 37.3.b) TRET)-, o, en cas d'adopció o acolliment, des de la resolució judicial per la qual es constitueix l'adopció o des de la decisió administrativa o judicial d'acolliment, fins a la finalització de la suspensió del contracte per maternitat o per adopció o acolliment. Ha de tenir-se en compte que part del descans per maternitat, o la totalitat en cas de defunció, pot ser transferida al treballador amb independència de l'exercici del permís per paternitat.

- El que comença immediatament després de la finalització del permís per maternitat.

En canvi, en el cas del PDI funcionari la duració del permís és de quinze dies i el seu gaudi comença amb la data del naixement. ${ }^{46}$ En el cas del PAs la duració és de vint dies naturals ininterromputs.

45. La Llei 9/2009, de 6 d'octubre, d'ampliació de la duració del permís de paternitat en els casos de naixement, adopció o acollida, citada, va ampliar la duració del permís per paternitat a quatre setmanes. No obstant això, la seua entrada en vigor s'ha anat ajornant durant quatre anys consecutius, fins a quedar fixada com a data d'entrada en vigor l' 1 de gener de 2015 en aquests moments. No ha d'oblidar-se que la Llei 2/2008, de 23 desembre, de pressupostos generals de l'Estat per a l'any 2009 (BOE del 24), va ampliar la suspensió per paternitat a vint dies quan el nou naixement, adopció o acolliment es produïsca en una família nombrosa, quan la família adquirisca la dita condició amb el nou naixement, adopció o acolliment o quan en la família hi haja una persona amb discapacitat.

46. Ha de tenir-se en compte que, d'acord amb la disposició transitòria sisena de l'EBEP, «Les Administracions Públiques ampliaran de forma progressiva i gradual la duració del permís de paternitat regulat en l'apartat c) de l'article 49 fins a aconseguir l'objectiu de quatre setmanes 
La suspensió per paternitat pot gaudir-se en règim de jornada a temps complet o a temps parcial, en aquest últim cas amb una extensió mínima del cinquanta per cent de la jornada -que, com es va tractar en el permís per maternitat, dóna lloc a l'extensió de la duració del permís en proporció a la reducció de jornada duta a terme. En el cas dels treballadors sotmesos a l'Estatut, hi ha d'haver un acord previ amb l'empresari en aquest sentit. També han de comunicar l'exercici d'aquest dret a l'empresari amb la deguda antelació, en els termes establits, si escau, en els convenis col·lectius.

Qualsevol millora en les condicions de treball a què es tinguera dret esdevinguda durant el període de suspensió també ha de beneficiar els que exercisquen el dret de conciliació tractat en aquest apartat. De la mateixa manera, si el període de gaudi del permís per paternitat ha coincidit amb el de vacances, el treballador podrà gaudir d'aquestes igualment en finalitzar el període de suspensió, fins i tot encara que haja finalitzat l'any natural a què corresponguen (art. 38.3 TRET).

El permís per paternitat dóna lloc a una suspensió del contracte de treball que exonera de les obligacions recíproques de treballar i remunerar el treball (art. 45.2 TRET). Per aquest motiu els treballadors sotmesos a l'Estatut compten amb una prestació de la Seguretat Social, la quantia de la qual equival al cent per cent de la base reguladora corresponent i la duració de la qual es correspon amb el període de descans que es gaudisca. ${ }^{47}$

El PDI funcionari i el PAs compta amb una garantia de plenitud dels seus drets durant tota l'extensió temporal del permís, tal com s'ha desenvolupat en ocasió de l'anàlisi del permís per maternitat.

d'aquest permís al cap de sis anys de l'entrada en vigor d'aquest Estatut». Les previsions contingudes en la nota al peu anterior sobre l'ampliació del permís per paternitat a vint dies, així com el successiu ajornament de l'entrada en vigor de les quatre setmanes de duració del permís per paternitat, també s'apliquen al personal funcionari.

47. Capítol Iv bis de la Llei general de la Seguretat Social i arts. 22 i ss. del Reial decret 295/2009, de 6 de març, pel qual es regulen les prestacions econòmiques del sistema de la Seguretat Social per maternitat, paternitat, risc durant l'embaràs i risc durant la lactància natural (BOE del 21). 
Per a saber-ne més:

$\Delta \Delta$ Sentència 1764/2013, de 8 març, del Tribunal Superior de Justícia de Catalunya (Sala Social) (rec. sup. 6517/2012) (AS 2013\1679).

$\mathbb{\square}$ Lousada Arochena, J. F. (2008): Permiso de paternidad y conciliación masculina, Bomarzo, Albacete.

\subsection{PERMÍS EN CAS DE FILLS O FILLES PREMATURS O HOSPITALITZATS A CONTINUACIÓ DEL PART}

Règim jurídic: arts. 37.4.bis i .6 TRET; art 48.g) EBEP; art. 68.3 Llei 10/2010; art. 10.7 i 11.1 Calendari laboral del PAs per a l'any 2014.

El personal de la Universitat Jaume I també compta amb un permís amb motiu del naixement de fills prematurs o que, per qualsevol altra causa, hagen de romandre hospitalitzats a continuació del part.

Es tracta d'un permís de naturalesa individual, de manera que correspon al treballador o empleat públic, siga dona o home. Només en el cas que ambdós progenitors treballen podrà ser exercit per un dels dos, atès que la regulació legal parla de «la mare o el pare» i de «la funcionària o el funcionari», això és, els cita en termes disjuntius i no copulatius.

El permís dóna dret a absentar-se del treball durant una hora dins de la jornada ordinària, en el cas del PDI contractat, o durant un màxim de dues hores diàries, en el cas del PDI funcionari i del PAS. En ambdós supòsits es continuaran percebent les retribucions íntegres. A més, el PDI contractat $\mathrm{i}$ funcionari pot reduir la jornada de treball fins a un màxim de dues hores, amb la disminució proporcional del seu salari en aquest cas. ${ }^{48}$ El PAs pot reduir igualment la seua jornada de treball

48. Cfr. l'article 211.5 LGSs, en relació amb l'increment al cent per cent de les bases de cotització per al càlcul de la base reguladora de la prestació per desocupació en aquest supòsit de reducció de jornada (art. 211.5 LGss). 
en dues hores com a màxim, però amb la percepció de les seues retribucions íntegres.

La concreció horària del permís i, si escau, de la reducció de jornada ha de ser efectuada pel PDI contractat d'acord amb el que preveu l'article 37.6 TRET, una regulació que serà tractada en ocasió de l'anàlisi del permís per lactància i l'acumulació d'hores de lactància.

Han de tenir-se en compte les opcions d'articulació d'aquest permís amb l'inici i l'extensió del permís per maternitat en supòsits de part prematur i en aquells que, per qualsevol altra causa, el nounat haja de romandre hospitalitzat a continuació del part, en la mesura que permet que ambdós progenitors puguen dedicar-se a tenir cura del nadó, de manera simultània o de manera consecutiva, encara que amb distinta intensitat.

Per a saber-ne més:

[Dd Vicente Pachés, F. de; Ibañez Gozalbo, M. (2001): «El permiso por maternidad en caso de nacimiento de hijo prematuro. Un supuesto lamentablemente olvidado»: Tribuna Social, 123: 20-25.

\subsection{PERMÍS PER LACTÀNCIA: ACUMULACIÓ D'HORES DE LACTÀNCIA}

Règim jurídic: art. 37.4 i 6 TRET; art 48.f) EBEP; arts. 69.1.c) i 71 Llei 10/2010; art. 10.6 del Calendari laboral del PAs per a l'any 2014.

El PDI contractat, siga dona o home, compta amb un permís per a la lactància d'un menor de nou mesos, siga fill biològic o adoptat, siga un menor acollit de forma preadoptiva, permanent o simple. En el cas del PDI funcionari i del PAs, l'edat del menor l'atenció del qual origina el permís per lactància ascendeix fins als dotze mesos.

Es tracta d'un permís la titularitat del qual és de naturalesa individual, de manera que correspon al treballador o empleat públic, siga 
dona o home. Només en el cas que ambdós progenitors treballen podrà ser exercit per un dels dos, de manera que en el cas que algun dels dos progenitors no treballe podrà ser exercit pel progenitor contractat $\mathrm{o}$ funcionari sense distinció de sexe, això és, siga dona o home.

Aquesta regulació de la titularitat individual del dret al permís per lactància té el seu origen en la sentència del Tribunal de Justícia de la Unió Europea de 30 de setembre de 2010 (assumpte Roca Álvarez). El Tribunal de la Unió va estimar que la regulació anterior, que condicionava el gaudi del permís pel pare treballador a què la mare fóra treballadora per compte d'altri, era contrària a la normativa comunitària, d'una banda, perquè prestava un tracte diferent de les dones treballadores i als homes treballadors, en la mesura que les titulars del permís eren les mares treballadores i els pares només podien gaudir-lo de mode vicari; i, d'una altra, perquè tal regulació, lluny de servir a la coresponsabilitat, podia «contribuir a perpetuar un repartiment tradicional de funcions entre l'home i la dona en mantenir els homes en una funció subsidiària de les dones respecte a l'exercici de la seua funció parental». De fet, el permís està actualment configurat de tal manera que s'aproxima més a una espècie de permís parental, reconegut a treballadores i treballadors en tant que progenitors, que a un permís per a assegurar la protecció de la condició biològica de la mare després del seu embaràs o la protecció de les particulars relacions entre la mare i el seu fill, com es va regular inicialment en l'Estatut dels treballadors. En conseqüència, pot afirmar-se que una adequada intel-lecció del permís permet considerar que el seu objecte ha de ser l'atenció del lactant.

La lactància pot ser indistintament natural o artificial. El permís pot exercir-se de tres formes distintes, mútuament excloents entre si, amb independència que es tracte d'una jornada a temps parcial o a temps complet:

- Per mitjà d'una hora d'absència del treball, que pot ser fraccionada en dues parts -que no han de ser necessàriament iguals ( $p$. 
e., quaranta minuts i vint minuts)-, depenent de les necessitats d'atenció del lactant.

- Per mitjà d'una reducció de la jornada de treball en mitja hora, que es diferencia del supòsit anterior perquè en aquest cas no hi ha obligació de tornar al treball per a finalitzar la jornada, sinó que es retarda l'inici o s'avança la finalització. En el cas PDI funcionari i del PAs, la reducció de la jornada normal arriba a una hora, que pot concentrar-se a l'inici o al final de la jornada de treball, o distribuir-se en dues fraccions iguals de mitja hora al començament i a la finalització d'aquella. L'opció per aquesta forma d'exercir el permís per lactància és compatible amb la reducció de jornada per motius familiars regulada en l'article 37.5 TRET i en l'article 48.h) EBEP. ${ }^{49}$

- Per mitjà de l'acumulació del temps de permís -novament, una hora- en jornades completes, d'acord amb les previsions de la negociació col·lectiva respecte d'això o segons l'acord a què s'arribe amb l'empresari, un acord que ha de respectar el que s'ha establit en aquella. En el cas del PDI funcionari -si bé l'art. 48.1.f) EBEP parla de «la funcionària»-, no es realitza cap referència ni a la negociació col·lectiva ni a l'acord amb l'empresari a l'hora de regular l'acumulació en jornades completes del temps de permís per lactància. El PAs que trie aquesta opció compta amb un permís retribuiit de vint-i-sis dies hàbils.

La duració del permís s'incrementa proporcionalment en casos de part, adopció o acolliment múltiple, la qual cosa, amb caràcter general, significa una hora addicional de permís - o mitja hora addicional de reducció- des del segon fill biològic, adoptat o acollit.

La concreció del moment en què s'efectuarà l'absència d'una hora o es reduirà la jornada de treball en mitja hora, així com la determinació del període de gaudi del permís de lactància correspon al treballa-

49. P. e., sentència 2575/2002, de 25 d'abril, del Tribunal Superior de Justícia de la Comunitat Valenciana, Sala Social (rec. sup. 1695/2000) (As 2003\1125). 
dor dins de la seua jornada ordinària. El treballador, llevat que concorreguera alguna causa de força major, ha de preavisar l'empresari amb una antelació de quinze dies, si el conveni col·lectiu no assenyala un altre termini, expressant la data d'inici i de finalització del permís de lactància amb precisió. En cas de discrepància entre el treballador i l'empresari sobre ambdós extrems, és a dir, la concreció horària i el període de gaudi, ha d'acudir-se a la modalitat processal sobre drets de conciliació de la vida personal, familiar i laboral, regulada en l'article 139 de la Llei 36/2011, de 10 d'octubre, reguladora de la jurisdicció social (BOE de 1'11).

El permís per lactància és retribuït, de manera que el seu exercici no pot donar lloc a una retribució inferior de la jornada de treball. La norma garanteix el salari íntegre, és a dir, com si es continuara completant la jornada ordinària de treball, la qual cosa inclou la percepció de tots els complements retributius que es percebien, també en el supòsit de la seua acumulació en jornades completes. Una solució diversa constituiria una discriminació directa per raó de maternitat, d'acord amb els articles 6 i 8 de la LOI.

Per a saber-ne més:

$\Delta \downarrow$ Sentència del Tribunal de Justícia de la Unió Europea (Sala Segona) de 30 de setembre de 2010 (petició de decisió prejudicial plantejada pel Tribunal Superior de Justícia de Galícia) - Pedro Manuel Roca Álvarez/Sesa Start Espanya ETT, S.A. (DOUE C 137, de 20 de novembre).

미 Goerlich Peset, J. M. (2008): «El tiempo de trabajo en la Ley Orgánica para la igualdad efectiva de mujeres y hombres». En Sala Franco, T.; Ballester Pastor, M. ${ }^{a}$ A.; Bañó León, J. M. ${ }^{\text {a; }}$ Embid Irujo, J. M. ${ }^{\text {; }}$ Goerlich Peset, J. M. (coords.): Comentarios a la Ley orgánica 3/2007, de 22 de marzo, para la igualdad efectiva de mujeres y hombres, La Ley, Madrid. 


\subsection{REDUCCIÓ DE LA JORNADA DE TREBALL PER GUARDA LEGAL}

Règim jurídic: arts. 37.5 i .6 TRET; art 48.h) EBEP; art. 68.3 Llei 10/2010; art. 11.1 Calendari laboral del PAs per a l'any 2014.

Una nova manifestació dels drets de conciliació es troba en el dret a reduir la jornada de qui, per motius de guarda legal, tinga sota la seua cura directa alguna de les persones següents:

- Un menor de dotze anys.

- Una persona amb discapacitat física, psíquica o sensorial, que no exercisca una activitat retribuïda. ${ }^{50}$

- Un familiar, fins al segon grau de consanguinitat o afinitat, ${ }^{51}$ que per raons d'edat, accident o malaltia no puga valdre's per si mateix i que no exercisca una activitat retribuïda.

La titularitat del dret és individual dels treballadors, siguen dones o homes. Només en el cas que dos o més treballadors de la mateixa empresa generaren aquest dret pel mateix subjecte causant, l'empresari podrà limitar el seu exercici simultani si hi ha raons justificades de funcionament de l'empresa.

La reducció ha d'efectuar-se en la jornada de treball diària-limitant en bona mesura, com s'exposarà més endavant, les opcions reductives que la jurisprudència havia admès als que exercien aquest dret de conciliació (reducció de jornada acompanyada de la selecció de certs torns o dies de treball més adequats per a la conciliació de la vida

50. En el cas del PAs, el Calendari laboral per a l'any 2014 exigeix que, en cas de realitzar una activitat retribuïda, ha de superar el salari mínim interprofessional per a motivar l'exclusió d'aquest supòsit.

51. En el primer grau de consanguinitat, tant del titular del dret com del seu cònjuge, es troben els ascendents (mare i pare) i descendents (filles i fills) directes; en el segon grau de consanguinitat s'inclouen les àvies i avis, germanes i germans, i nétes i néts. En el primer grau d'afinitat es troben la sogra, el sogre, la nora i el gendre; en el segon grau d'afinitat se situen la cunyada i el cunyat. 
familiar i laboral). L'extensió de la reducció no ha de ser inferior a una vuitena part ni superior a la meitat de la duració de la jornada diària.

La concreció del període de temps i del moment en què es reduirà la jornada de treball diària correspon al treballador. S'ha de tenir en compte que els convenis col-lectius poden establir criteris per a regular la concreció horària de la reducció de jornada, atenent l'efectivitat dels drets de conciliació i les necessitats productives i organitzatives de l'empresa.

El treballador, llevat que concorreguera alguna causa de força major, ha de preavisar l'empresari amb una antelació de quinze dies, si el conveni col-lectiu no assenyala un altre termini, expressant la data d'inici i de finalització de la reducció de jornada amb precisió. En cas de discrepància entre el treballador i l'empresari sobre ambdós extrems, és a dir, la concreció horària i el període de gaudi, ha d'acudir-se a la modalitat processal sobre drets de conciliació de la vida personal, familiar i laboral, regulada en l'article 139 de la Llei 36/2011, de 10 d'octubre, reguladora de la jurisdicció social (BOE de 1'11).

La principal conseqüència de l'exercici d'aquest dret és la disminució del salari en la mateixa proporció en què es reduïsca la jornada de treball, sense perjudici de certes previsions en matèria de Seguretat Social sobre aquest punt. $^{52}$

La regulació d'aquest dret de conciliació presenta alguna particularitat en el cas del PDI funcionari. En primer lloc, s'inclou entre els subjectes destinataris de la prestació de cures alguna persona gran que requerisca especial dedicació. En segon lloc, no es marca cap límit

52. Cfr., a l'efecte de Seguretat Social, els mecanismes de compensació previstos en cas de reducció de jornada en virtut de l'article 37.5 TRET per a combatre els efectes desfavorables que pogueren derivar-se en les prestacions per jubilació, incapacitat permanent, mort, supervivència, maternitat i paternitat (art. 180.3 LGSS), així com en la prestació per desocupació (art. 211.5 LGSs), que efectua un còmput de les cotitzacions efectuades durant la reducció de jornada incrementades fins al cent per cent de la quantia que hauria correspost sense tal reducció durant els dos primers anys en cas d'atenció de menors de dotze anys, i durant un any en els dos restants supòsits (art. 180.3 LGSS). Quan la reducció de jornada estiga seguida d'una excedència de les previstes en l'article 46.3 TRET, es computarà l'increment en les cotitzacions indicat a l'efecte de la consideració com a cotitzats dels períodes de posterior excedència que corresponguen (art. 180.4 LGSs). 
mínim o màxim en l'extensió de la reducció. En tercer terme, no s'ha introduit cap referència al fet que la reducció haja de produir-se dins de la jornada de treball «diària».

En el cas del PAs, quan el subjecte destinatari de les cures és una persona gran que requerisca especial dedicació, s'exigeix prèviament una resolució o informe de l'òrgan corresponent de l'administració sanitària. També s'inclouen com a familiars els cònjuges o parelles de fet. Quan la reducció siga de duració inferior a una hora diària no es reduirà la retribució, llevat que el subjecte destinatari de les cures siga un menor de dotze anys que no requerisca una dedicació especial.

Per a saber-ne més:

$\Delta \Delta$ Sentència 3/2007, de 15 de gener, del Tribunal Constitucional.

Ballester Pastor, M. ${ }^{a}$ A. (2012): " De cómo la reforma operada por el

RD Ley 3/2012 ha degradado el derecho fundamental a la conciliación de responsabilidades»: Revista de Derecho Social, 57: 99-114.

\subsection{PERMÍS PER ACCIDENT O MALALTIA GREU DE FAMILIARS FINS AL SEGON GRAU DE CONSANGUINITAT O AFINITAT}

Règim jurídic: arts. 37.3.b) TRET; art 48.a) EBEP; art. 69.1.f) Llei 10/2010; art. 10.1 Calendari laboral del PAs per a l'any 2014.

El personal laboral i funcionari compta amb un permís retribuït en cas d'accident o malaltia greu d'un familiar dins del segon grau de consanguinitat o afinitat.

En el cas del PDI contractat, pot exercir aquest permís retribuït, sempre amb l'avís previ i justificació, quan el parent haja patit un accident, patisca una malaltia greu, haja sigut hospitalitzat o haja patit una intervenció quirúrgica sense hospitalització que requerisca repòs domiciliari. La duració del permís és de dos dies, que s'amplia a quatre dies si el treballador té la necessitat de desplaçar-se a aquest efecte. 
En el cas del PDI funcionari, l'EBEP efectua una distinció en la duració del permís atenent el grau de proximitat del familiar accidentat o amb una malaltia greu. Quan es troba dins del primer grau de consanguinitat $\mathrm{o}$ afinitat, la duració és de tres dies hàbils, que s'amplien a cinc quan haja de desplaçar-se a una localitat distinta. En canvi, quan es troba dins del segon grau de consanguinitat o afinitat, la duració del permís es redueix a dos dies hàbils, llevat que haja de desplaçar-se a una localitat distinta, $i$ en aquest cas s'amplia a quatre dies.

Aquest règim jurídic varia en el cas del PAs. Quan el familiar -entre els quals també s'inclouen el cònjuge o parella de fet- es troba dins del primer grau de consanguinitat o afinitat, la duració és de tres dies hàbils, que s'amplien a cinc quan el fet causant ocórrega a més de cent quilòmetres de distància de la seua localitat de residència. En canvi, quan es troba en segon grau de consanguinitat o afinitat, la duració del permís es redueix a dos dies, llevat que el fet causant ocórrega a més de cent quilòmetres de distància de la seua localitat de residència, que s'amplia a quatre dies. Cada vegada que s'acredite una situació de gravetat es tindrà dret a exercir aquest permís. Si els dies d'hospitalització foren finalment inferiors als de duració d'aquest permís i no concorreguera certificat de gravetat, la duració es reduirà als dies en què el familiar haja estat efectivament hospitalitzat. Els dies de permís es podran utilitzar seguits o alterns, a petició del personal, en cas de malaltia greu, hospitalització en institució sanitària o hospitalització domiciliària de llarga duració.

Per a saber-ne més:

$\Delta \Delta$ Sentència 212/2011, de 24 octubre, del Tribunal Superior de Justícia de les Illes Canàries (Sala Contenciosa Administrativa) (JUR 2012185071).

ㅁ] García Ninet, J. I. (dir.); Garrigues Giménez, A. (coord.) (2007): Comentarios a la Ley de igualdad, cIss - Wolters Wluwer, Madrid. 


\subsection{REDUCCIÓ PER ATENCIÓ A FAMILIAR DE PRIMER GRAU PER MALALTIA MOLT GREU}

Règim jurídic: art 48.i) EBEP; art. 68.3 Llei 10/2010; art. 11.1 Calendari laboral del PAs per a l'any 2014.

El PDI funcionari compta amb el dret a reduir la seua jornada laboral per a l'atenció d'un familiar de primer grau per raó de malaltia molt greu-sense especificar el parentiu consanguini o afí que haja d'haverhi. El PAs compta amb aquest permís per a atendre el cònjuge, parella de fet o familiar de primer grau, també per raó de malaltia molt greu, sempre que requerisca hospitalització en una institució sanitària o en el domicili.

L'extensió de la reducció pot arribar fins al cinquanta per cent de la jornada laboral i la seua duració no pot superar un mes. En el cas que hi haguera més d'un titular d'aquest dret de conciliació amb base en el mateix fet causant, la reducció de la jornada podrà prorratejarse entre tals titulars, però sempre amb una duració màxima d'un mes.

La reducció de jornada no suposa la corresponent minva salarial, en comptar amb un caràcter retribuït.

\subsection{REDUCCIÓ PER ATENCIÓ A MENOR AFECTAT PER CÀNCER O PER UNA ALTRA MALALTIA GREU}

Règim jurídic: art. 37.5 i .6 TRET: art. 49.e) EBEP; art. 68.3 Llei 10/2010; art. 10.15 Calendari laboral del PAs per a l'any 2014.

El PDI contractat -i, amb les excepcions que s'indicaran més endavant, el PDI funcionari i el PAS- compta amb un nou dret de conciliació en cas de dedicar-se a tenir cura d'un menor a càrrec seu afectat per càncer -tumors malignes, melanomes i carcinomes- o per qualsevol 
altra malaltia greu, ${ }^{53}$ sempre que es complisquen tres requisits, el primer de caràcter subjectiu i els dos restants de tipus objectiu: tractar-se del progenitor, adoptant o acollidor preadoptiu o permanent del menor; requerir un ingrés hospitalari de llarga duració; i, finalment, cuidar de manera directa, continua i permanent el menor, extrem aquest últim que ha de ser acreditat per l'informe del servei públic de salut o de l'òrgan administratiu sanitari de la comunitat autònoma competent.

El contingut d'aquest nou dret és una reducció de la jornada de treball l'extensió de la qual mínima és la meitat de la duració de la dita jornada. ${ }^{54} \mathrm{El}$ dret pot ser exercit fins que el menor complisca divuit anys. Els convenis col·lectius poden regular els supòsits en què aquesta reducció de jornada pot acumular-se en jornades completes i les condicions que han de complir-se per a això.

La titularitat del dret és individual dels treballadors, siguen dones o homes. Només en el cas que dos o més treballadors de la mateixa empresa generaren aquest dret pel mateix subjecte causant, l'empresari pot limitar el seu exercici simultani si hi ha raons justificades de funcionament de l'empresa.

La concreció del període de temps i del moment en què es reduirà la jornada de treball diària correspon al personal contractat. Ha de tenir-se en compte que els convenis col-lectius poden establir criteris per a regular la concreció horària de la reducció de jornada, atenent l'efectivitat dels drets de conciliació i les necessitats productives $\mathrm{i}$ organitzatives de l'empresa.

El PDI contractat, llevat que concorreguera alguna causa de força major, ha de preavisar l'empresari amb una antelació de quinze dies, si el conveni col·lectiu no assenyala un altre termini, expressant la data d'inici i de finalització de la reducció de jornada amb precisió. En cas

53. Les malalties greus a què es refereix aquesta regulació s'enumeren en l'annex al Reial decret 1148/2011, de 29 de juliol, per a l'aplicació i desenvolupament, en el sistema de la Seguretat Social, de la prestació econòmica per atenció de menors afectats per càncer o per una altra malaltia greu (BOE del 30).

54. El personal sotmès a la Llei de la funció pública valenciana té definit el límit màxim de la reducció al vuitanta per cent de la duració de la jornada de treball. 
de discrepància entre el treballador i l'empresari sobre ambdós extrems, és a dir, la concreció horària i el període de gaudi, ha d'acudir-se a la modalitat processal sobre drets de conciliació de la vida personal, familiar i laboral, regulada en l'article 139 de la Llei 36/2011, de 10 d'octubre, reguladora de la jurisdicció social (BOE de 1'11).

La principal conseqüència de l'exercici d'aquest dret pel PDI -i, exclusivament a aquest efecte, del PAs laboral- és la disminució del salari en la mateixa proporció en què es reduïsca la jornada de treball, sense perjudici de les previsions de Seguretat Social a aquest respecte. ${ }^{55}$

La regulació d'aquest dret de conciliació presenta alguna particularitat en el cas del PDI funcionari i del PAS. En primer lloc, s'exigeix que ambdós progenitors treballen - la qual cosa va en contra de la coresponsabilitat a què han de servir els drets de conciliació i possiblement també del dret europeu, atenent el contingut de la sentència del cas Roca Álvarez, ja citada. En segon lloc, es tracta d'una reducció de jornada que no té efectes retributius desfavorables, ja que el PDI $\mathrm{i}$ el PAS funcionari rebrà íntegrament les seues retribucions -no així el PAs laboral, com s'ha indicat. Possiblement a causa d'aquest tractament retributiu s'estableixen a continuació certes excepcions a la regla general indicada sobre aquest punt. Així, quan ambdós progenitors, adoptants o acollidors puguen exercir aquest dret o puguen ser beneficiaris de la prestació corresponent de la Seguretat Social, la funcionària $o$ funcionari tindrà dret a la reducció de jornada amb percepció de les seues retribucions íntegres sempre que l'altre titular que exerceix aquest dret no cobre les seues retribucions íntegres o no siga beneficiari de la prestació corresponent de la Seguretat Social. En cas contrari, la persona interessada pot exercir el dret a la reducció de jornada però amb la reducció proporcional en les seues retribucions. En tercer lloc, quan ambdós titulars del dret presten serveis en un mateix organisme

55. Cfr., a l'efecte de Seguretat Social, la prestació econòmica prevista en aquest supòsit per a compensar la pèrdua d'ingressos derivada de la reducció del salari proporcional a la reducció de jornada (art. 135 quater LGSS), així com el còmput de les cotitzacions efectuades durant la reducció de jornada incrementades fins al cent per cent de la quantia que hauria correspost sense tal reducció (art. 180.3 LGSs). 
o entitat, aquesta podrà limitar el seu exercici simultani per raons fundades en el funcionament correcte del servei. Finalment, es preveu per al PDI funcionari que es regulen reglamentàriament els supòsits en què aquesta reducció de jornada pot acumular-se en jornades completes i les condicions que han de complir-se per a això.

Per a saber-ne més:

$\Delta \mathbb{1} \Delta$ Sentència 7/2013, de 9 gener, del Jutjat Social núm. 19 de Madrid (AS 2013 221 ).

미 Mella Méndez, L.: «El cuidado de menores afectados por cáncer u otra enfermedad grave: análisis crítico de la regulación laboral y de seguridad social». Relaciones Laborales. Revista crítica de teoría y práctica, 1: 89-121.

\subsection{EXCEDÈNCIA PER ATENCIÓ A FILLES O FILLS O FAMILIARS A CÀRREC SEU}

Règim jurídic: art. 46.3 TRET: art. 89.4 EBEP; arts. 126.d) i 130 Llei 10/2010.

La plantilla universitària compta amb un nou dret de conciliació consistent en una excedència la duració de la qual varia segons es destine per a tenir cura de cada fill natural, adoptiu o acollit de manera permanent o preadoptiva, fins i tot provisionalment; o per a tenir cura d'un familiar fins al segon grau de consanguinitat o afinitat, que per raons d'edat, accident, malaltia o discapacitat no puga valdre's per si mateix i no exercisca una activitat retribuïda.

En el primer supòsit la duració de l'excedència, que començarà a comptar de la data de naixement o, si escau, de la resolució judicial o administrativa, no pot superar els tres anys; en el segon supòsit la duració de l'excedència no pot superar els dos anys. Aquest dret de conciliació pot exercir-se de forma fraccionada, sempre dins de cada un dels dos períodes de duració. En qualsevol dels dos casos, la nego- 
ciació col·lectiva pot admetre una duració més extensa del període d'excedència.

El període d'excedència serà únic per cada subjecte causant. Quan el titular d'aquest dret inicie un nou període d'excedència per a tenir cura d'un nou subjecte causant dels enunciats, el nou període d'excedència conclourà el que es gaudia sense solució de continuïtat, de manera que no es tracta de períodes acumulatius sinó consecutius.

La titularitat del dret és individual dels treballadors, siguen dones o homes. Només en el cas que dos o més assalariats de la mateixa empresa generaren aquest dret pel mateix subjecte causant, l'empresari pot limitar el seu exercici simultani si hi ha raons justificades de funcionament de l'empresa.

El PDI contractat té dret a la reserva del seu lloc de treball durant el primer any d'excedència, un termini que s'amplia fins a quinze mesos, si qui exerceix el dret forma part d'una família que tinga reconeguda oficialment la condició de família nombrosa, i fins a divuit mesos si es tracta d'una família nombrosa de categoria especial. ${ }^{56}$ Una vegada transcorreguts els terminis indicats, la reserva es practica sobre un lloc de treball del mateix grup professional o categoria equivalent.

La duració d'aquesta excedència és computable a l'efecte d'antiguitat - amb les conseqüències que d'això es deriven, per exemple, en el càlcul de les indemnitzacions per acomiadament. Aquest personal també té dret a l'assistència als cursos de formació professional que s'organitzen, especialment en ocasió de la seua reincorporació, per a la qual cosa ha de ser convocat per l'empresari oportunament.

L'exercici d'aquest dret de conciliació dóna lloc a una suspensió del contracte de treball en el PDI contractat, que exonera de les obligacions recíproques de treballar i remunerar el treball (art. 45.2 TRET), sense perjudici de les previsions en matèria de Seguretat Social sobre aquesta qüestió. ${ }^{57}$

56. Cfr. Llei 4/2003, de 18 de novembre, de protecció a les famílies nombroses (BOE del 19).

57. No obstant això, hi ha una prestació familiar de contingut no econòmic i de caràcter retributiu que considera com a període de cotització efectiva els dos primers anys d'excedència per atenció de fills o menors acollits, un termini que s'amplia a trenta mesos, si s'esdevé en una famí- 
L'exercici d'aquest dret de conciliació presenta novament alguna particularitat en el cas del PDI funcionari. En primer lloc, el període de duració de l'excedència per atenció de familiar s'iguala a tres anys, com en el cas de fills naturals, adoptats o acollits. En segon lloc, el temps en excedència computarà als efectes de triennis, carrera i drets en el règim de Seguretat Social d'aplicació. En tercer lloc, la reserva del lloc de treball s'amplia a dos anys, transcorreguts els quals, només es reserva un lloc en la mateixa localitat i amb la mateixa retribució. Com en el cas del personal laboral, el personal funcionari pot participar en els cursos de formació que convoque l'Administració durant el període d'excedència.

El PAs presenta les següents particularitats respecte al règim del personal funcionari descrit en el paràgraf anterior: s'inclou el cònjuge o parella de fet legalment constituïda; ${ }^{58}$ la reserva del lloc de treball obtingut amb destí definitiu s'amplia fins als tres anys de duració de l'excedència; en cas d'ocupar el lloc de treball amb caràcter provisional, la reserva es manté en tres anys sempre que el lloc no siga objecte de provisió amb destí definitiu o que, si escau, s'incorpore el seu titular. L'excedència també pot ser gaudida pel personal interí, mantenint-se la reserva del lloc de treball mentre no concórrega cap de les causes de cessament previstes legalment.

lia nombrosa, i a trenta-sis mesos, si la família nombrosa és de categoria especial. En canvi, quan es tracta d'una excedència per atenció de familiars el període de cotització efectiva considerat es redueix al primer any d'excedència. Cfr. 180.1 LGSs.

58. La recentíssima STC 39/2014, d'11 de març, declara inconstitucional i nul l'incís «drets de la Seguretat Social que els siga aplicable» previst en l'article 130.4 de la Llei 10/2010, de 9 de juliol, quan l'excedència s'exerceix precisament per a aquest supòsit afegit pel seu article 130.1.b), que es declara constitucional (FFJ 7 i 8). 
Per a saber-ne més:

$\Delta \downarrow \Delta$ Sentència 393/2011, de 6 de juliol, del Tribunal Superior de Justícia d’Aragó (Sala Contenciosa Administrativa) (rec. ap. 174/2010) (RJCA 2011\751).

$\llbracket \square$ Sánchez Trigueros, C.; Sempere Navarro, A.V. (dirs.) (2008): Comentarios a la Ley Orgánica 3/2007, de 22 de marzo, para la igualdad efectiva de mujeres y hombres, Thomson - Aranzadi, Cizur Menor (Navarra).

\subsection{ADAPTACIÓ DE LA JORNADA DE TREBALL}

Règim jurídic: art. 34.8 TRET.

El PDI contractat té dret a adaptar la duració i la distribució de la seua jornada de treball per a fer efectiu el seu dret de conciliació de la vida personal, familiar i laboral. Ara bé, l'exercici d'aquest dret ha de produir-se, d'acord amb el precepte que el regula, «en els termes que s'establisquen en la negociació col·lectiva o en l'acord a què arribe amb l'empresari», que en tot cas ha de respectar el que s'ha previst en aquella. La regulació transcrita ha portat a considerar que es tracta d'una mera expectativa de dret condicionada a l'existència d'un conveni col·lectiu o, si no n'hi ha, a la consecució d'un acord amb l'empresari que permeta el seu exercici efectiu. $\mathrm{O}$, en un altre sentit, que no cap un exercici unilateral d'aquest dret per part del treballador, sinó que tal exercici està sotmès necessàriament al que es dispose en un conveni col·lectiu o a l'acord a què arribe amb l'empresari (sSTC 24/2011, de 14 de març, i 26/2011, de 14 de març).

Entre els continguts de la negociació col-lectiva que poden fer efectiu el dret a l'adaptació de la jornada de treball s'inclouen la utilització de la jornada contínua i l'horari flexible com dos exemples d'organització del temps de treball i dels descansos que permeten compatibilitzar de manera òptima els drets de conciliació i la millora de la productivitat en les empreses. 
Per a saber-ne més:

$\Delta$ ¿ Sentència 24/2011, de 14 de març, del Tribunal Constitucional.

[D] Cabeza Pereiro, J.; Fernández Prieto, M. (2011): «Comentario a las Sentencias del Tribunal Constitucional 24 y 26/2011, de 14 de marzo»: Relaciones Laborales, 21 (II): 811-840.

\section{ALTRES MESURES DE CONCILIACIÓ}

Règim jurídic: art. 48.j) EBEP; Resolució de 28 de desembre de 2012, de la Secretaria d'Estat d'Administracions Públiques, per la qual es dicten instruccions sobre jornada $i$ horaris de treball del personal al servei de 1'Administració General de l'Estat i els seus organismes públics; Calendari laboral del PAs per a l'any 2014; I Pla d'Igualtat de la Universitat Jaume I.

\subsection{FLEXIBILITAT DE LA PERMANÈNCIA OBLIGATÒRIA}

La Universitat Jaume I pot autoritzar el PDI funcionari a flexibilitzar en una hora diària l'horari fix de jornada que tinga establida quan té a càrrec seu persones grans, fills menors de dotze anys o persones amb discapacitat, així com quan té a càrrec seu directe un familiar amb malaltia greu fins al segon grau de consanguinitat o afinitat. Si té a càrrec seu persones amb discapacitat fins al primer grau de consanguinitat o afinitat, es poden disposar de dues hores de flexibilitat horària diària sobre l'horari fix per a conciliar l'horari del lloc de treball amb els horaris dels centres educatius ordinaris d'integració i d'educació especial, dels centres d'habilitació i rehabilitació, dels serveis socials i centres ocupacionals, així com altres centres específics on la persona amb discapacitat reba atenció. En el cas que les persones amb discapacitat a càrrec seu siguen les seues filles o fills, pot absentar-se del treball pel temps indispensable per a assistir a reunions de coordi- 
nació del seu centre educatiu, ordinari d'integració o d'educació especial, on reba atenció, tractament o per a acompanyar-lo si ha de rebre suport addicional en l'àmbit sanitari o social.

Amb caràcter excepcional, per motius directament relacionats amb els drets de conciliació i, en particular, en els casos de famílies monoparentals, els òrgans competents en matèria de personal poden autoritzar, de manera personal i temporal, la modificació de l'horari fix en un màxim de dues hores. El límit de dues hores no està expressament previst en el Calendari laboral del PAs per a l'any 2014, que assigna l'autorització prèvia d'aquesta modificació a la Gerència i la limita a l'horari que hi ha entre l'obertura i el tancament dels edificis.

En el cas del PAs, el règim de flexibilitat de l'horari de permanència obligatòria presenta les següents particularitats en relació amb els termes de flexibilitat que s'acaben d'exposar: en primer lloc, la flexibilitat en una hora diària s'aplica al personal que tinga a càrrec seu persones de seixanta-cinc anys o d'una edat superior que requerisquen una especial dedicació; filles o fills menors de dotze anys, així com menors en acolliment, preadoptiu o permanent, de la dita edat; o un familiar fins al segon grau de consanguinitat o afinitat amb malaltia greu o amb un grau de discapacitat igual o superior al $65 \%$. Aquests mateixos supòsits donen lloc a una flexibilitat de dues hores en cas de famílies monoparentals. En el cas que les filles o fills siguen discapacitats, o que els menors en acolliment preadoptiu o permanent compten amb una discapacitat, poden disposar de dues hores diàries sobre l'horari de permanència obligatòria per a conciliar l'horari del lloc de treball amb els horaris dels centres educatius ordinaris d'integració $i$ d'educació especial, així com altres centres específics on la persona amb discapacitat reba atenció.

En tots els supòsits anteriors la flexibilitat no dóna lloc a una reducció de jornada, per la qual cosa el personal ha de recuperar les dites hores. En el cas del PAs, la recuperació ha de produir-se dins del mes natural o dels dos mesos següents. 


\subsection{PERMÍS PER A VISITES MÈDIQUES I ASSISTÈNCIA A PERSONES MENORS, ANCIANES I AMB DISCAPACITAT}

El PDI funcionari compta amb un permís pel temps indispensable per al compliment de deures relacionats amb la conciliació de la vida familiar i laboral. ${ }^{59}$

El PAs compta amb un permís per a acudir dins de la seua jornada laboral, per necessitats pròpies, de menors o de grans amb parentiu de primer grau, tant per consanguinitat com per afinitat, de discapacitats físics, psíquics o sensorials a càrrec seu, o del seu cònjuge, als esdeveniments següents: $a$ ) consultes, tractaments i exploracions de tipus mèdic; $b$ ) reunions de coordinació dels seus centres d'educació especial; i c) consultes de suport addicional en l'àmbit sociosanitari. La duració del permís s'estén al temps indispensable per a la seua realització. Quan es tracte d'una visita programada, ha de justificar-se amb caràcter previ; si és una atenció d'urgència, ha de justificar-se amb posterioritat.

En cas de malaltia greu d'un fill menor de catorze anys, sense necessitat d'hospitalització, es podrà concedir fins a un màxim de tres dies hàbils a la mare o al pare, quan siga necessària l'assistència personalitzada per acreditació de la malaltia per part del facultatiu competent i sempre que els dos treballen.

\subsection{REDUCCIÓ DE JORNADA PER RAÓ DE MALALTIA LLARGA O CRÒNICA}

El PAs que, per raó de malaltia llarga o crònica, no puga realitzar la seua jornada laboral completa -un extrem que ha de ser certificat

59. Recentment, un ofici de la Divisió de Consultoria, Assessorament i Assistència de Recursos Humans de la Direcció General de la Funció Pública, dependent de la Secretaria d'Estat per a la Funció Pública, amb data 26 de març de 2013, ha interpretat que el tractament que ha de donar-se a les absències d'un treballador que, d'acord amb un certificat mèdic, ha de realitzar cures domiciliàries al seu fill correspon al compliment d'un deure inexcusable de caràcter públic, sempre que la dita necessitat s'acredite per mitjà de certificat mèdic, es justifiquen degudament els requisits legalment establits i pel temps indispensable per al compliment de l'obligació. 
prèviament per la Unitat de Valoració d'Incapacitats-, tindrà dret a una disminució de fins a la meitat de la seua jornada de treball, amb reducció proporcional de les seues retribucions, llevat que no supere una hora diària. La reducció ha de ser concedida pel rector, amb l'informe previ de la Gerència i amb el vistiplau de la persona responsable de la seua unitat o servei.

\subsection{LLICÈNCIA PER MALALTIA DE FAMILIARS}

El PAS pot sol-licitar una llicència per malaltia de familiars, amb una duració màxima d'un any. S'entén per familiars la cònjuge o el cònjuge, la parella de fet o el familiar en línia directa o col·lateral fins al segon grau, per consanguinitat o afinitat, que es trobe legalment sota la guarda o custòdia de la persona sol-licitant i que patisca una malaltia greu o irreversible, acreditada suficientment amb els informes mèdics necessaris, que requerisca una atenció continuada.

El període que dure aquesta llicència tindrà la consideració de serveis efectivament prestats, als efectes exclusivament del còmput d'antiguitat i consolidació de grau. S'exclou expressament la seua consideració per al còmput de les vacances anuals i del permís per assumptes propis.

\subsection{PREFERÈNCIA EN L'ELECCIÓ D'HORARIS O EN L'ASSISTÈNCIA A CURSOS DE FORMACIÓ (I PLA D'IGUALTAT DE L'UJI)}

D’acord amb l'acció núm. 66 del I Pla d'Igualtat de la Universitat Jaume I de Castelló (2010-2014), correspon als consells de departament, en el marc de la planificació docent del seu professorat, adoptar un acord en què s'establisca la preferència en l'elecció d'horaris lectius del PDI -sense distinció del seu caràcter laboral o funcionari- amb 
filles o fills menors de dotze anys, $\mathrm{o} a \mathrm{mb}$ familiars a càrrec seu $\mathrm{amb}$ discapacitat o en situació de dependència, tenint sempre en compte que la franja horària de conciliació se situa des de les nou del matí fins a les sis de la vesprada.

D'acord amb l'acció 75 del mateix Pla, s'estableix que el PDi i el PAS que s'incorpore al treball després de gaudir del permís per maternitat, paternitat o d'una excedència per a l'atenció de menors o familiars a càrrec seu, ${ }^{60}$ tenen preferència en l'accés als cursos de formació oferits per la Universitat.

\section{ELS DRETS DE CONCILIACIÓ DE LES VÍCTIMES DE VIOLÈNCIA DE GÈNERE}

Règim jurídic: arts. 37.7, 40.3.bis, 45.1.n) i 49.1.m) TRET: arts. 49.d), 82, 89.1.d) i .5 EBEP; arts. 17.6, 68.4, 69.3.d) 109, 113.3, 131 i DA 8a Llei 10/2010; arts. 10.13 i 11.3 Calendari laboral del PAs per a l'any 2014.

Els drets de conciliació de les víctimes de violència de gènere compten amb un tractament separat en la mesura que no es dirigeixen en primera instància a facilitar la conciliació de la vida professional amb la familiar, sinó amb la personal, en la mesura que estan destinats amb caràcter inicial a garantir la protecció de les víctimes de la violència de gènere. De fet, segons la regulació continguda en l'article 37.7 TRET, el dret a la reducció de la jornada de treball de les víctimes de violència de gènere es reconeix «per a fer efectiva la seua protecció o el seu dret a l'assistència social integral». Es tracta d'uns drets, en conseqüència, vinculats necessàriament amb la protecció de la vida, la integritat física i moral de les víctimes de violència de gènere (art. $15 \mathrm{CE}$ ).

En aquest sentit, en el cas del PDI contractat, les faltes d'assistència al treball motivades per la situació física o psicològica derivades de violència de gènere, acreditades pels serveis socials d'atenció o els

60. Pot interpretar-se que també està inclòs el personal que s'incorpore després d'un permís per adopció i acolliment, ja que la seua exclusió esdevindria discriminatòria (arts. 14 i 39.2 CE). 
serveis de salut, segons siga procedent, no es computaran com a faltes d'assistència al treball de les que permeten un acomiadament objectiu de la treballadora. La regulació que afecta el personal funcionari es refereix exclusivament a les faltes d'assistència, sense vincular-les expressament a cap situació física o psicològica, $\mathrm{i}$ inclou tant les faltes d'assistència totals com parcials, que tindran la consideració de justificades pel temps i les condicions en què així ho determinen els serveis socials d'atenció o de salut, segons pertoque.

Les víctimes de violència de gènere tenen dret a la reducció de la seua jornada de treball, amb disminució proporcional del seu salari, o a la reordenació del seu temps de treball, en aquest segon cas a través de l'adaptació de l'horari de treball, l'aplicació de l'horari flexible o d'altres formes d'ordenació del temps de treball que s'utilitzen en l'empresa. En el cas del PDI contractat, sempre en els termes que preveuen els convenis col-lectius o en els acords entre 1'empresa i els representants dels treballadors, o conforme a l'acord entre l'empresa i els treballadors afectats. Si aquests acords no existiren, la concreció de la reordenació del temps de treball correspondrà als treballadors, d'acord amb les regles previstes en l'article 37.6 TRET, ja exposades -incloses les relatives a la resolució de discrepàncies-; i, en el cas del personal funcionari, l'exercici del dret a la reordenació del temps de treball ha d'efectuar-se en els termes que per a aquests supòsits establisca l'administració pública corresponent.

El PDI contractat que es veja obligat a abandonar el lloc de treball en la localitat on prestara els seus serveis per ser víctimes de violència de gènere, a causa de la necessitat de fer efectiva la seua protecció o el dret a l'assistència social integral, té dret preferent a ocupar un altre lloc de treball, del mateix grup professional o categoria equivalent, que l'empresa tinga vacant en qualsevol altre dels seus centres de treball. L'empresa estarà obligada a comunicar als treballadors les vacants existents en el dit moment o les que es puguen produir en el futur. El canvi de centre de treball tindrà una duració inicial de sis mesos, durant els quals l'empresa tindrà l'obligació de reservar el lloc 
de treball que anteriorment ocupaven els treballadors. Una vegada finalitzat aquest període, els treballadors podran optar entre tornar al seu lloc de treball anterior o romandre en el nou. En aquest últim cas desapareixerà l'obligació de reserva.

En el cas del personal funcionari, tindrà dret al trasllat a un altre lloc de treball propi del seu cos, escala o categoria professional, d'anàlogues característiques, sense necessitat que siga vacant de necessària cobertura. El trasllat tindrà la consideració de forçós. En tals supòsits l'administració pública competent estarà obligada a comunicar les vacants ubicades en la mateixa localitat o en les localitats que la interessada expressament sol-licite. ${ }^{61}$

Les víctimes de violència de gènere poden suspendre el seu contracte de treball, si són personal contractat, quan es vegen obligades a abandonar el seu lloc de treball per aquest motiu. ${ }^{62}$ En el cas del personal funcionari, poden sol-licitar una excedència per raó de violència de gènere, sense necessitat d'haver prestat un temps mínim de serveis previs i sense que siga exigible un termini de permanència en aquella. Tindran dret a la reserva del lloc de treball durant els sis primers mesos i el dit període computarà als efectes d'antiguitat, carrera i drets del règim de la Seguretat Social que s'hi apliquen. Aquest període es podrà prorrogar per tres mesos, fins a un màxim de divuit, quan les actuacions judicials ho exigiren, amb idèntics efectes als assenyalats. A més, durant els dos primers mesos d'excedència la funcionària tindrà dret a percebre les retribucions íntegres i, si escau, les prestacions familiars per tenir un fill a càrrec seu.

El PAs al qual resulta d'aplicació la Llei de la funció pública valenciana compta amb les següents particularitats en aquest terreny:

61. En les actuacions i procediments relacionats amb la violència de gènere ha de protegir-se la intimitat de les víctimes, en especial, les seues dades personals, les dels seus descendents i les de qualsevol persona que estiga sota la seua guarda o custòdia.

62. D'acord amb l'article 208.2 LGSs, estaran en situació legal de desocupació les treballadores que suspenguen el seu contracte per raó de violència de gènere. En la mateixa situació es trobaran si extingeixen el seu contracte de treball pel mateix motiu (arts. 49.1.m) TRET i 208.1 LGSs). 
- La reducció de jornada que no supere una hora diària no generarà la disminució de les retribucions.

- El trasllat per violència de gènere tindrà caràcter provisional $\mathrm{i}$ es preveu que, si no hi havia llocs vacants en el seu cos, agrupació funcionarial o escala, la víctima de violència de gènere podrà ser adscrita a un altre lloc del mateix grup o subgrup professional a què pertanya, sense detriment dels seus drets econòmics. També es concreta que, en comptar amb la consideració de trasllat forçós, comporta la percepció de les indemnitzacions establides reglamentàriament per a aquest tipus de trasllats. També s'indica que, atès el seu caràcter provisional, la duració del trasllat vindrà condicionada al manteniment de les circumstàncies que van donar-hi lloc. També es requereix l'acreditació de la situació de violència de gènere per mitjà de l'ordre judicial de protecció a la víctima o, de manera excepcional fins al seu dictat, informe del ministeri fiscal que n'indique l'existència d'indicis.

- L'excedència s'aplica expressament a les funcionàries interines i es manté la reserva del lloc de treball mentre no es produïsca el seu cessament per alguna de les causes previstes en el mateix text legal.

- Es reconeix la preferència de les víctimes de la violència de gènere a les activitats formatives organitzades per l'Administració.

Per a saber-ne més:

$\Delta \Delta$ Sentència 1609/2007, de 2 novembre, del Tribunal Superior de Justícia de Castella-La Manxa (Sala Social) (rec. sup. 1117/2007) (AS 2008\489). 미 Mateu Carruana, M. J.: Medidas laborales de protección social y de fomento del empleo para las víctimas de violencia de género, Dykinson, Madrid. 


\section{ALGUNES REFLEXIONS FINALS}

La revisió del contingut dels drets de conciliació inclosos en l'Enquesta per a conèixer la percepció i les necessitats de conciliació de la vida familiar i laboral del personal de la Universitat Jaume I de Castelló permet apreciar la complexitat del seu règim jurídic, la casuística dominant en la seua ordenació -d'una banda, amb regles generals infestades d'excepcions i, d'un altra, amb excepcions amb vocació de regla general- $\mathrm{i}$ les seues evidents limitacions a 1'hora de complir la finalitat marcada per l'article 44 LOI, això és, fomentar l'assumpció equilibrada de responsabilitats familiars o, el que és el mateix, la coresponsabilitat.

Per a comprendre adequadament per què els drets de conciliació compten amb aquesta regulació legal ha de posar-se de manifest que el seu reconeixement pot considerar-se una excepció dins de l'excepció que suposa el dret del treball en l'ordenament jurídic de les regles autònomes del mercat que es du a terme amb el dret modern. En particular, si el subjecte interioritzat en el dret modern va ser l'home, blanc i propietari (Balaguer Callejón, 2005; Ventura Franch 1999), una excepció a aquest ve donada per l'home no propietari o, dit en termes més exactes, l'home obrer o proletari que, al llarg del segle XIX, es va convertir en el centre d'una nova branca de l'ordenament jurídic sorgida, precisament, al seu voltant: el dret del treball (Borrajo Dacruz, 2009).

Doncs bé, una vegada desenvolupada aquesta branca de l'ordenament jurídic excepcional, en la mesura que queda en certa manera al marge dels principis bàsics del dret dels contractes (autonomia de la voluntat, igualtat entre les parts contractants, etc.), i després de la incorporació massiva de les dones al treball retribuït i per compte d'altri, el subjecte interioritzat per la norma jurídica -l'obrer o proletari- tampoc es correspon finalment amb el subjecte real sobre el qual s'aplica la norma laboral, això és, la dona obrera o proletària. La conseqüència directa d'aquest marc general és que la regulació legal dels drets de 
conciliació compta amb un encaix molt problemàtic en el dret del treball, en particular, i en el dret, en general.

A més, s'ha de tenir en compte que el dret del treball és un dret proteccionista que parteix de la idea que els treballadors i els empresaris no tenen condicions d'igualtat a l'hora d'establir una relació contractual i, per això, intervé establint una sèrie de mesures per a protegir la part més dèbil. La incorporació de la dona al treball per compte d'altri incrementa la complexitat a què ha de donar resposta aquest dret proteccionista en què, a més, apareixen nous subjectes que, no sols requereixen altres mesures, sinó que posen en dubte les que ja estaven establides, en la mesura que la seua aplicació sobre els nous subjectes no produeixen els efectes esperats. En l'objecte d'estudi que ens ocupa, doncs, mentre l'obrer ni ha de parir ni ha de complir un mandat de gènere per a l'atenció posterior de la prole (rol productiu), la dona obrera engendra filles i fills i s'encarrega de la seua atenció (rol reproductiu) -en definitiva, la pervivència de la divisió sexual del treball en tant que són les dones les que han d'encarregar-se del treball domèstic també. ${ }^{63}$ Davant d'aquesta realitat social, el dret del treball ha incorporat una excepció (la dona treballadora) a l'excepció (l'home treballador) del subjecte interioritzat pel dret modern, un subjecte que perviu en gran manera en el dret contemporani.

De fet, el subjecte dels drets de conciliació interioritzat en la norma s'identifica amb les dones, que són les que han de complir amb el mandat de gènere corresponent. És cert que els drets de conciliació suposen en la pràctica una ajuda per a les dones treballadores, però també ho és que reforcen la divisió sexual del treball -en la mesura que no qüestionen l'assumpció de la majoria de les tasques d'atenció per part de les treballadores- perquè, en intentar propiciar la conciliació de la vida familiar i la professional, els seus destinataris directes acaben sent fonamentalment els que assumeixen la vida familiar, és a dir, predominantment les dones, la qual cosa perpetua tal divisió. Per

63. Cal subratllar que es tracta d'un mandat de gènere i no d'un mandat legal. En aquest sentit, la modificació del Codi civil en 2005 pel que fa al dret a contraure matrimoni ha incorporat l'obligació d'ambdós cònjuges de «compartir les responsabilitats domèstiques i l'atenció i cura d'ascendents i descendents $\mathrm{i}$ altres persones dependents a càrrec seu». 
consegüent, contribueixen de manera molt limitada a la coresponsabilitat, en la mesura que, com s'acaba de manifestar, les seues destinatàries acaben sent fonamentalment les dones en la majoria dels casos -una excepció la constitueix el permís de paternitat. ${ }^{64}$

Des d'una perspectiva crítica les mesures de conciliació han de dissenyar-se tenint en compte que els homes i les dones han de coresponsabilitzar-se en igualtat de condicions de les labors d'atenció. Així, partint de les diferents realitats que tenen les unes i els altres, els drets de conciliació haurien de complir dos objectius bàsics: el primer, qüestionar el model basat en la divisió sexual del treball i, el segon, permetre la conciliació de la vida personal, familiar i laboral. Un exemple de l'anterior l'ofereixen els permisos individuals i intransferibles o el permís parental indistint, en què una part es reserva al pare (Rodríguez Rodríguez, 2010).

L'anterior aproximació crítica no impedeix reconèixer que les mesures de conciliació han coadjuvat a l'avanç en la incorporació i permanència de les dones en el món laboral, fonamentalment per mitjà de dues estratègies certament rellevants: d'una banda, reforçar la indemnitat de les dones treballadores, de tal manera que l'ordenament laboral garantisca que la maternitat i les tasques d'atenció no donen lloc a tractes adversos o efectes negatius - p. e., la nul-litat radical de l'acomiadament i de la no-renovació d'un contracte de treball temporal, si s'entén la conciliació des d'una perspectiva àmplia (ssTC 92/2008, de 21 de juliol i 175/2005, de 4 de juliol, respectivament); $-{ }^{65}$ i, d'altra banda, reduir en alguna mesura el conflicte entre els períodes de dedicació familiar i dedicació professional -el binomi família-treball-, facilitant la seua sincronització - permisos, suspensions, reduccions horàries- o la seua seqüenciació -excedències- en el temps.

64. Vid., respecte d'això, l'Informe-diagnòstic sobre igualtat a la Universitat Jaume I de Castelló, elaborat per la Fundació Isonomia (2009), sobre l'exercici dels drets de conciliació pel personal universitari, els resultats de la qual van revelar que el $83 \%$ dels que empraven mecanismes de conciliació eren dones.

65. En canvi, la recent STC 173/2013, de 10 d'octubre, ha conclòs que la regulació de l'article 55.5.b) TRET no és aplicable a la resolució empresarial de la relació laboral esdevinguda durant el període de prova de les treballadores embarassades. 


\section{CAPÍTOL III \\ CARACTERÍSTIQUES \\ SOCIODEMOGRÀFIQUES DEL PERSONAL \\ TREBALLADOR DE LA UNIVERSITAT JAUME I}

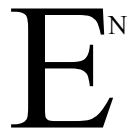

In AQUEST CAPÍTOL S'INCLOU informació rellevant sobre els treballadors i les treballadores de l'Uu que se centra principalment en quatre variables: el sexe, l'edat, la categoria professional i el centre de la universitat on s'ubiquen. Amb això es pretén proporcionar una descripció de la situació de la plantilla de la Universitat que ens ajude, aplicant la perspectiva de gènere, a aconseguir un nivell més elevat d'equitat.

L'exposició s'inicia amb les dades del present curs 2013/14, proporcionades pel Servei de Recursos Humans i amb data 1 d'octubre de 2013. S'intercalarà informació relativa al curs 1991/92, per ser 1991 l'any de creació de la Universitat Jaume I, amb la finalitat de mostrar una perspectiva temporal i extraure conclusions sobre els canvis succeïts en els últims vint anys.

Entre les dues dates previstes en el present text, es va efectuar, l'any 2009, el Diagnòstic de la situació en matèria d'igualtat de dones i homes a la Universitat Jaume ${ }^{66}$. L'estudi va ser realitzat per la Fundació Isonomia amb l'objectiu de servir d'utilitat per a la redacció del I Pla d'Igualtat de 1'uJi (2010-2014).

Posteriorment, la Unitat d'Igualtat de l'Us va realitzar dues ampliacions al Diagnòstic, el 2010 i el 2011. ${ }^{67}$

66. Podeu consultar el diagnòstic en la pàgina web de la Unitat d'Igualtat www.ui.uji.es.

67. Ídem. 
El personal de l'UJ inclou el personal docent $\mathrm{i}$ investigador (PDI) $\mathrm{i}$ el personal d'administració i serveis (PAS). Al moment de la redacció d'aquest text, el personal de l'usI està format per 1.946 persones, de les quals 1.329 són PDI (el 68,3 \%) i 617 PAS $(31,7 \%)$.

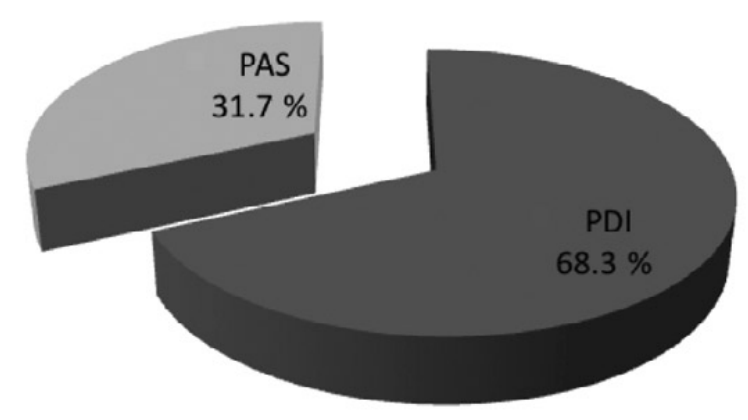

Gràific 1.

Distribució del personal a la Universitat Jaume I el 2013

S'indiquen a continuació amb més detall les característiques més destacades en cada un d'aquests grups de personal de l'us.

\section{EL PERSONAL D'ADMINISTRACIÓ I SERVEIS (PAS)}

La distribució per sexe de les 617 persones que integren aquest col-lectiu en data 1 d'octubre de 2013 és la següent: 365 dones (59\%) i 252 homes (41\%).

El pas en la Universitat Jaume I inclou, doncs, un nombre més elevat de dones que d'homes, si bé la proporció entra dins dels límits considerats com a equitatius, i se situa en una proporció semblant a la de la resta d'universitats públiques a Espanya, que és del $59,2 \%$ en aquest mateix curs (Dades bàsiques del sistema universitari espanyol, 2013). 
A continuació exposarem dades del PAs examinant els següents aspectes, els quals encreuarem sempre amb la variable sexe: en primer lloc, la relació jurídica que vincula al PAS amb la Universitat Jaume I; en segon lloc, segons el nivell jeràrquic i el sistema de classificació professional del PAS; en tercer lloc, la ubicació del pas en l'estructura organitzativa de la Universitat; i finalment, l'edat de les treballadores i treballadors del PAs.

\subsection{EL PAS SEGONS SEXE I RELACIÓ JURÍDICA AMB L’UJI}

El PAS es vincula jurídicament amb l'us per mitjà de tres tipus de relació: el de funcionari de carrera, el de funcionari interí i el de personal laboral eventual.

El tipus de relació és important, ja que en temes com la conciliació entre la vida laboral i familiar dóna lloc a l'aplicació d'una legislació o d'una altra, tal com ha aparegut en el capítol segon.

La taula següent ens mostra la distribució del PAS segons la seua relació laboral:

\section{Taula 1.}

Distribució del PAS segons la vinculació laboral amb l'uJ el 2013

\begin{tabular}{cccc} 
& $\begin{array}{c}\text { Funcionariat } \\
\text { de carrera \% }\end{array}$ & $\begin{array}{c}\text { Funcionariat } \\
\text { interí \% }\end{array}$ & $\begin{array}{c}\text { Personal } \\
\text { laboral \% }\end{array}$ \\
\hline Dones & 58,5 & 66,4 & 56,6 \\
Homes & 41,5 & 33,6 & 43,4 \\
Total & 441 & 116 & 60 \\
\hline
\end{tabular}

Els gràfics següents mostren la distribució del pas segons relació laboral i sexe. 


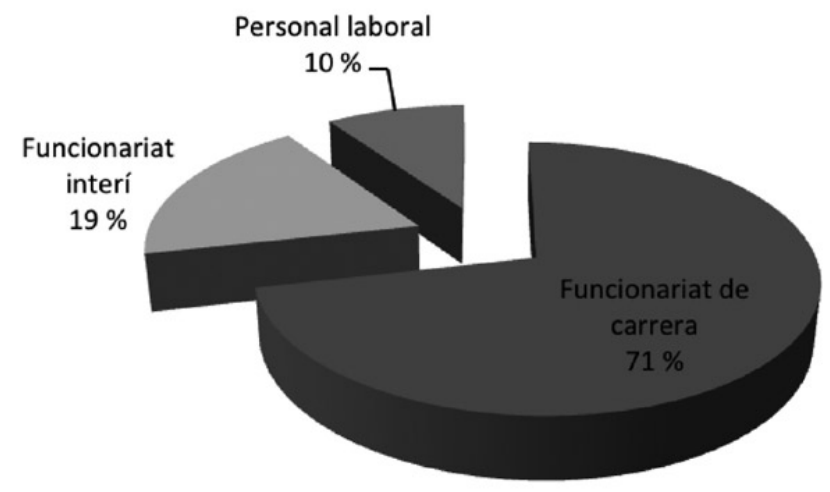

Gràfic 2.

Distribució del PAs segons vinculació laboral amb l'UJI el 2013

Com s'observa en el gràfic, el tipus de vincle jurídic que més predomina a l'uJ és el de funcionari de carrera. En el gràfic següent es mostren les diferències per sexe.

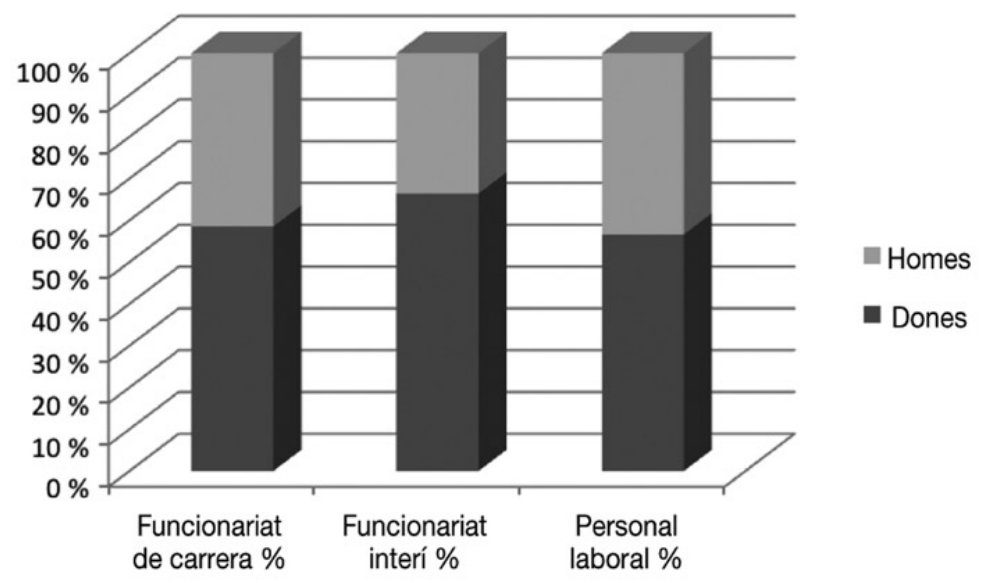

Gràfic 3.

Distribució del PAS segons vinculació laboral amb l'UJI el 2013 per sexe 
La diferència per sexes més notable es produeix en el funcionari interí (66,4 \% enfront de 33,6\%), on el nombre de dones dobla el d'homes. La distància menor entre els sexes quant al tipus de vincle laboral amb la Universitat es dóna en el personal laboral, amb una diferència de 13 punts percentuals.

\subsection{CLASSIFICACIÓ PROFESSIONAL DEL PAS PER SEXE}

Com hem comentat anteriorment, el PAS de la Universitat està feminitzat. La taula següent mostra la distribució per categories laborals i per sexe. El seu objectiu és conèixer si es produeix algun tipus de segregació vertical entre els sexes que supose, en última instància, desigualtat.

Taula 2.

Distribució del PAS per categoria i sexe el $2013^{68}$

\begin{tabular}{lrcc} 
& Total & Dones \% & Homes \% \\
Grupo A1 amb direcció & 30 & 40,3 & 59,7 \\
Grupo A1 sense direcció & 82 & 52,5 & 47,5 \\
Grupo A2 amb direcció & 2 & 100 & \\
Grupo A2 sense direcció & 90 & 58,1 & 41,9 \\
Grupo B & 3 & 100 & \\
Grupo C1 amb direcció & 57 & 66,1 & 33,9 \\
Grupo C1 sense direcció & 280 & 58,8 & 41,2 \\
Grupo C2 sense direcció & 73 & 60 & 40 \\
\hline
\end{tabular}

68. L'article 76 de La Llei 7/2007, 12 d'abril EBEP, «Grups de classificació professional del personal funcionari de carrera»: el grup A per al qual s'exigeix títol universitari i que al seu torn se subdivideix en A1 (que realitza funcions de responsabilitat) i l'A2 que no les realitza; el grup B, per al qual s'exigeix estar en possessió del títol de tècnic superior, i el grup $\mathrm{C}$, subdividit en $\mathrm{C} 1$ (títol de batxiller o tècnic) i C2 (títol de graduat o graduada en educació secundària obligatòria). L'article 77 de la mateixa llei, indica que el personal laboral s'ha de classificar de conformitat amb la legislació laboral. 
En el següent gràfic s'observen amb més claredat les diferències per sexe en les distintes categories.

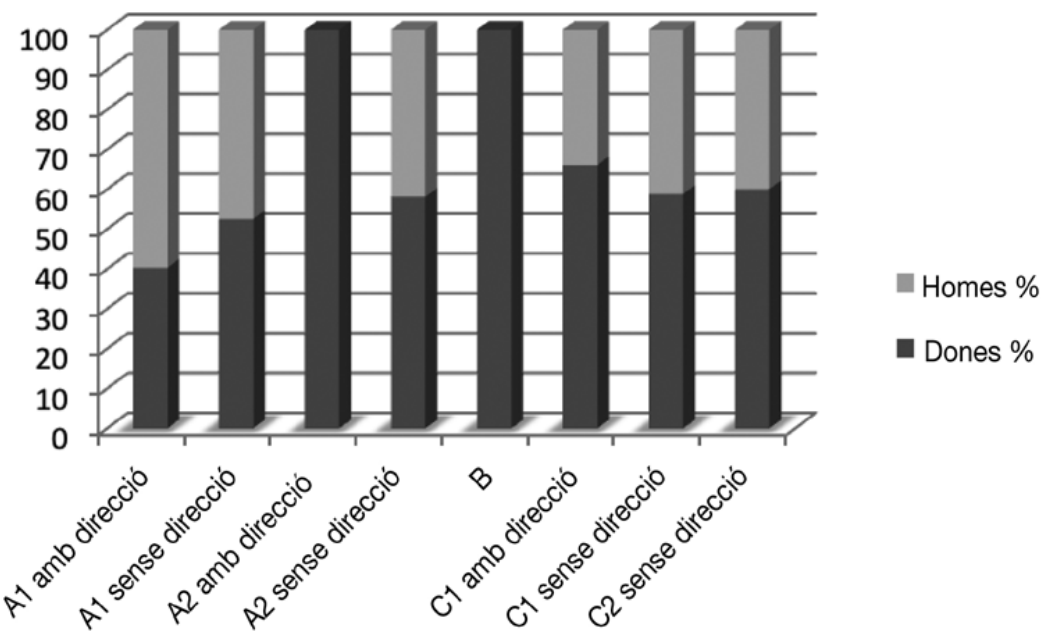

Gràfic 4.

Distribució del PAs per categoria i sexe el 2013

La proporció que hi ha en el conjunt del PAs favorable a les dones s'inverteix en el grup A1 amb direcció. En aquest grup els homes ocupen el $60 \%$ dels llocs corresponents als nivells més alts dels serveis de la Universitat. La resta de categories es caracteritza per tenir una major proporció de dones.

Es produeix, com veurem posteriorment per a les càtedres en el PDI, el denominat sostre de vidre que perjudica clarament les dones en els llocs més alts de la jerarquia administrativa a la Universitat, en aquest cas en el grup A1 amb direcció.

El 1991, quan es va crear la Universitat, el nombre de PAs, segons dades proporcionats pel Servei de Recursos Humans de l'usi, era de 65 , dels quals el $64,6 \%$ eren dones i el $35,4 \%$ eren homes. 
En aqueixa data les categories es distribuïen en grup A, per al qual es necessitava el títol de llicenciatura o doctorat o equivalent; el grup B, per al qual es necessitava el títol de diplomatura o equivalent; el grup $\mathrm{C}$, per al qual es necessitava el títol de batxillerat o equivalent; el grup D, que exigia el títol de graduat o graduada escolar o equivalent i, finalment, el grup E, que exigia exclusivament un certificat d'escolaritat.

El fet de la feminització del sector de l'administració a la Universitat és semblant al que s'esdevé en altres àmbits de l'Administració pública. Ara bé, i com va assenyalar Fenollosa (1992), la distribució piramidal que reflecteix la posició laboral diferenciada del personal d'administració i serveis, és ocupada en els estrats superiors pels homes, mentre que en els estrats mitjans i inferiors, s'incorporen majoritàriament les dones.

Així, les ocupacions amb menor qualificació, segons la catalogació que d'aquestes es realitza, i comparativament, pitjor remunerades, amb menor prestigi i més allunyades de l'exercici del poder, presenten una marcada feminització. Tendència que queda patent en la taula i gràfic que es mostren a continuació.

Comparant 1991 amb 2013, s'ha incrementat la participació masculina del PAs de l'UJI en quasi cinc punts percentuals com s'observa en la taula següent:

Taula 3.

Distribució del PAS per categoria i sexe el 1991

\begin{tabular}{lccc} 
& Total & Dones \% & Homes \% \\
Grup A sense direcció & 2 & & 100 \\
Grup B amb direcció & 2 & 50 & 50 \\
Grup B sense direcció & 7 & 28,6 & 71,4 \\
Grup C amb direcció & 1 & 100 & \\
Grup C sense direcció & 4 & 25 & 75 \\
Grup D amb direcció & 19 & 94,7 & 5,3 \\
Grup D sense direcció & 16 & 56,2 & 43,8 \\
Grup E sense dirección & 14 & 71,4 & 28,6 \\
\hline
\end{tabular}




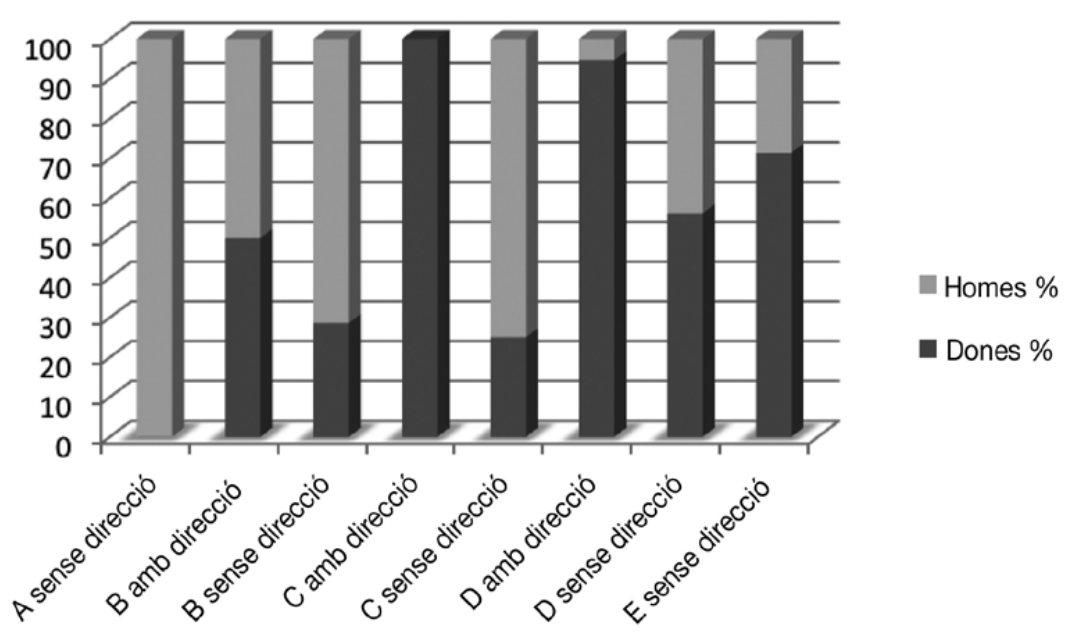

Gràfic 5.

Distribució del PAS per categoria i sexe el 1991

Encara que les categories en aquests dos anys són diferents, sí que es constata la segregació vertical existent si tenim en compte que la proporció en els grups amb més categoria professional és sempre favorable als homes, mentre que en els grups amb menor categoria, els grups D i E, la proporció és favorable a les dones, sent el grup que presenta una major feminització el grup $\mathrm{D}$ amb direcció.

\subsection{DISTRIBUCIÓ DEL PAS EN L'ESTRUCTURA ORGANITZATIVA DE L'UJI}

En l'estructura organitzativa de l'UJI (Diagnòstic, 2009), el PAS s'ubica en dos nivells: en primer lloc, els òrgans de govern, administració i representació d'acord amb els Estatuts de l'UJI (2003, 2010) comprenent cada un d'aquests àmbits òrgans unipersonals i òrgans 
col-legiats; i, en segon lloc, la distribució funcional de les unitats organitzatives de la Universitat, estructurades en facultats i escoles tècniques, departaments, instituts d'investigació $i$ altres centres $i$ estructures creats per a la realització de funcions docents, activitats de caràcter científic, tècnic, artístic o de prestació de serveis. Així mateix, els serveis universitaris són unitats específiques de suport per al desenvolupament de les activitats de la Universitat en compliment dels seus objectius.

La taula següent inclou la distribució del PAs per sexe entre els distints centres i serveis de la Universitat en l'actualitat. Atesos els canvis realitzats tant en els centres com en els serveis ens referirem exclusivament a la situació el 2013, considerant la dificultat per a realitzar comparacions a causa de l'increment del nombre de centres i de nous serveis des de 1991 fins a l'actualitat.

Taula 4.

Distribució del PAS per centres i serveis el 2013

\begin{tabular}{lrcc} 
& Total & Dones \% & Homes \% \\
\hline Biblioteca & 39 & 71.8 & 28.2 \\
Càtedra UNESCO & 3 & 66.6 & 33.3 \\
$\begin{array}{l}\text { Centre d'Estudis de Postgrau i } \\
\text { Formació Continuada }\end{array}$ & 3 & 100 & \\
Consell Social & 3 & 66.6 & 33.3 \\
$\begin{array}{l}\text { Edifici de Rectorat i Serveis } \\
\text { Centrals }\end{array}$ & 273 & 57.9 & 42.1 \\
Edifici Investigació I. Mòdul I & 6 & 66.6 & 33.3
\end{tabular}




\section{Total Dones \% Homes \%}

Escola Superior de Tecnologia i

Ciències Experimentals

$136 \quad 54,4 \quad 45,6$

Facultat de Ciències de la Salut

29

62,1

37,9

Facultat de Ciències Humanes i

Socials

43

67,4

32,6

Facultat de Ciències Jurídiques i

Econòmiques

28

57,1

42,9

Institut Universitari de Tecnologia

Ceràmica Agustín Escardino

$3 \quad 66,6 \quad 33,3$

Oficina de Cooperació al

Desenvolupament i Solidaritat

Oficina de Relacions Internacionals

$8 \quad 50$

50

Oficina d'Inserció Professional i

Estades en Pràctiques

9

88,8

11,1

Servei d'Esports

26

42,3

57,7

La taula indica que tots els serveis presenten una clara feminització, excepte el Servei d'Esports. Ara bé, en les taules següents s'observa la distribució de cada una de les categories laborals per centres i serveis, tenint en compte la perspectiva vertical o jeràrquica i l'horitzontal. 


\section{Taula 5 .}

Distribució del grup A1 amb direcció per centres o serveis

\begin{tabular}{|c|c|c|c|}
\hline & Total & Dones \% & Homes \% \\
\hline Biblioteca & 2 & 50 & 50 \\
\hline $\begin{array}{l}\text { Edifici de Rectorat i Serveis } \\
\text { Centrals }\end{array}$ & 18 & 34,6 & 65,4 \\
\hline $\begin{array}{l}\text { Escola Superior de Tecnologia } \\
\text { i Ciències Experimentals }\end{array}$ & 4 & 75 & 25 \\
\hline $\begin{array}{l}\text { Facultat de Ciències Humanes } \\
\text { i Socials }\end{array}$ & 2 & 50 & 50 \\
\hline $\begin{array}{l}\text { Facultat de Ciències } \\
\text { Jurídiques i Econòmiques }\end{array}$ & 2 & 100 & \\
\hline Consell social & 1 & & 100 \\
\hline
\end{tabular}

Com es veu en la taula anterior, la representació més elevada del grup A1 amb direcció s'ubica a l'edifici del Rectorat, amb una majoritària representació masculina; no obstant això, a 1'Escola, es manifesta una major feminització.

Taula 6.

Distribució grup A1 sense direcció per centres

\section{Total Dones \% Homes \%}

Edifici de Rectorat i Serveis Centrals

$34 \quad 41,2 \quad 58,8$

Edifici Investigació I. Mòdul I

$4 \quad 75$

25 


\section{Total Dones \% Homes \%}

Escola Superior de Tecnologia i

Ciències Experimentals

$\begin{array}{lll}20 & 40 & 60\end{array}$

Facultat de Ciències de la Salut

66,6

Institut Universitari de Tecnologia

Ceràmica Agustín Escardino

100

Oficina de Cooperació al

Desenvolupament i Solidaritat

Oficina d'Inserció Professional i

Estades en Pràctiques

4

75

25

Oficina de Relacions Internacionals

$3 \quad 100$

En aquesta categoria és més elevada la presència de les dones, si bé i d'acord amb les dades presentades, la presència d'homes és més alta a l'edifici del Rectorat i a l'Escola de Tecnologia. L'explicació pot trobar-se en el fet que a l'edifici del Rectorat s'ubiquen els òrgans de direcció de la Universitat i que 1'Escola és «territori masculinitzat», com veurem també posteriorment per al PDI.

Taula 7.

Distribució del grup A2 amb direcció per centres

\begin{tabular}{lccc} 
& Total & Dones \% & Homes \% \\
\hline Càtedra UNESCO & 1 & 100 \\
$\begin{array}{l}\text { Edifici de Rectorat i Serveis } \\
\text { Centrals }\end{array}$ & 1 & 100 \\
\hline
\end{tabular}


Taula 8.

Distribució del grup A2 sense direcció per centres

\begin{tabular}{lccc} 
& Total & Dones \% & Homes \% \\
Biblioteca & 6 & 100 & \\
Centre d'Estudis de Postgrau i & 1 & 100 & \\
Formació Continuada & & & \\
$\begin{array}{l}\text { Edifici de Rectorat i Serveis } \\
\text { Centrals }\end{array}$ & 49 & 58,8 & 41,2 \\
Edifici Investigació I. Mòdul I & 1 & & 100 \\
Escola Superior de Tecnologia i & 23 & 43,5 & 56,5 \\
Ciències Experimentals & & & \\
Facultat de Ciències de la Salut & 1 & 100 & 66,6 \\
$\begin{array}{l}\text { Facultat de Ciències Humanes i } \\
\text { Socials }\end{array}$ & 3 & 33,3 & \\
$\begin{array}{l}\text { Facultat de Ciències Jurídiques i } \\
\text { Econòmiques }\end{array}$ & 2 & 100 & \\
Oficina de Cooperació al & & & \\
Desenvolupament i Solidaritat & 5 & 80 & \\
Oficina d'Inserció Professional i & 2 & 100 & \\
Estades en Pràctiques & & \\
Servei d'Esports & 4 & & \\
\hline
\end{tabular}

En aquest grup s'inclouen llocs de treball que exigeixen una qualificació universitària però sense tenir responsabilitat de direcció i, encara que majoritàriament predominen les dones en el conjunt dels centres, a l'Escola i a la Facultat de Ciències Humanes i Socials, els homes tenen una representació més elevada. 
Taula 9.

Distribució del grup B per centres

\section{Total Dones \% Homes \%}

Facultat de Ciències de la Salut 3 100

Si bé el cent per cent del grup $\mathrm{B}$ està ocupat per dones, això no és molt representatiu, ja que són només tres les persones així classificades. Aquest col-lectiu respon a l'anterior grup B, en la classificació anterior, que inclou els diplomats i diplomades, categoria que ja no existeix en l'actualitat perquè tots els estudiants universitaris tenen ara la categoria de graduats o graduades quan es titulen a la Universitat.

Taula 10.

Distribució del grup $\mathrm{C} 1 \mathrm{amb}$ direcció per centres

\begin{tabular}{lccc} 
& Total & Dones \% & Homes \% \\
Biblioteca & 1 & 100 & \\
$\begin{array}{l}\text { Centre d'Estudis de Postgrau i } \\
\text { Formació Continuada }\end{array}$ & 1 & 100 & \\
Consell Social & 1 & 100 & \\
$\begin{array}{l}\text { Edifici de Rectorat i Serveis } \\
\text { Centrals }\end{array}$ & 39 & 63,7 & 36,3 \\
$\begin{array}{l}\text { Escola Superior de Tecnologia i } \\
\text { Ciències Experimentals }\end{array}$ & 6 & 100 & \\
Facultat de Ciències de la Salut & 1 & 100 & \\
$\begin{array}{l}\text { Facultat de Ciències Humanes i } \\
\text { Socials }\end{array}$ & 4 & 100 & \\
Facultat de Ciències Jurídiques i & 4 & 50 & 50 \\
Econòmiques & & & \\
\hline
\end{tabular}


Tant el grup $\mathrm{C}$ amb direcció com el grup $\mathrm{C}$ sense direcció estan clarament feminitzats en pràcticament tots els centres, i és l'edifici del Rectorat on hi ha un nombre més alt de PAs d'aquesta categoria $i$ on la proporció d'homes és superior a la resta de centres.

Taula 11.

Distribució del grup C1 sense direcció per centres

$\begin{array}{lccc} & \text { Total } & \text { Dones \% } & \text { Homes \% } \\ \text { Biblioteca } & 16 & 62,5 & 37,5 \\ \text { Càtedra Unesco } & 2 & 50 & 50 \\ \text { Centre d'Estudis de Postgrau i } & 1 & 100 & \\ \text { Formació Continuada } & & & 60 \\ \begin{array}{l}\text { Edifici de Rectorat i Serveis } \\ \text { Centrals }\end{array} & 110 & 40 & \\ \text { Edifici Investigació I. Mòdul I } & 1 & 100 & \\ \begin{array}{l}\text { Escola Superior de Tecnologia i } \\ \text { Ciències Experimentals }\end{array} & 72 & 54,8 & 45,2 \\ \begin{array}{l}\text { Facultat de Ciències de la Salut } \\ \text { Facultat de Ciències Humanes i }\end{array} & 12 & 50 & 25,9 \\ \text { Socials } & 27 & 74,1 & \\ \begin{array}{l}\text { Facultat de Ciències Jurídiques i } \\ \text { Econòmiques }\end{array} & 15 & 53,3 & 46,6 \\ \begin{array}{l}\text { Institut Universitari de Tecnologia } \\ \text { Ceràmica Agustín Escardino }\end{array} & 1 & 100 & \\ \begin{array}{l}\text { Oficina de Cooperació al } \\ \text { Desenvolupament i Solidaritat }\end{array} & 1 & 100 & \\ \begin{array}{l}\text { Oficina de Relacions } \\ \text { Internacionals }\end{array} & 4 & 50 & \\ \end{array}$




\section{Total Dones \% Homes \%}

Oficina d'Inserció Professional i

Estades en Pràctiques

Servei d'Esports

$3 \quad 100$

$4 \quad 50$

50

El grup C1 sense direcció és el més nombrós dins del PAs, amb 280 persones, de les quals el 58,8 \% són dones. La seua presència és majoritària en tots els centres excepte en l'edifici del Rectorat, en què la participació és masculina en el $60 \%$, superant la femenina.

Taula 12.

Distribució del C2 sense direcció per centres

\begin{tabular}{lccc} 
& Total & Dones \% & Homes \% \\
Biblioteca & 14 & 71,4 & 28,6 \\
Consell Social & 1 & 100 & \\
$\begin{array}{l}\text { Edifici de Rectorat i Serveis } \\
\text { Centrals }\end{array}$ & 18 & 85,7 & 14,3 \\
$\begin{array}{l}\text { Escola Superior de Tecnologia i } \\
\text { Ciències Experimentals }\end{array}$ & 11 & 70 & 30 \\
Facultat de Ciències de la Salut & 3 & 33,3 & 66,6 \\
$\begin{array}{l}\text { Facultat de Ciències Humanes i } \\
\text { Socials }\end{array}$ & 7 & 42,8 & 57,2 \\
$\begin{array}{l}\text { Facultat de Ciències Jurídiques i } \\
\text { Econòmiques }\end{array}$ & 5 & 40 & 60 \\
$\begin{array}{l}\text { Institut Universitari de Tecnologia } \\
\text { Ceràmica Agustín Escardino }\end{array}$ & 1 & & \\
Servei d'Esports & 19 & 47,4 & 52,6 \\
\hline
\end{tabular}


Aquest últim grup presenta una heterogeneïtat en la seua distribució segons sexe: les tres facultats, l'Institut de Tecnologia Ceràmica i el Servei d'Esports mostren una representació masculina més elevada; no obstant això, en centres habitualment masculinitzats, com ara el Rectorat i l'Escola, la proporció femenina és més alta.

Per a concloure aquest apartat relacionat amb l'estructura organitzativa de la Universitat en relació amb el sexe, exposem la següent taula que inclou informació dels cinc centres més nombrosos de l'Us: els quatre centres relacionats amb l'activitat docent i l'edifici del Rectorat, en el qual s'ubiquen els òrgans de govern i administració de la Universitat.

Taula 13.

Distribució del PAS per centres i sexe el 2013

\begin{tabular}{lccc} 
& Total & Dones \% & Homes \% \\
Rectorat & 272 & 58,8 & 41,2 \\
ESTCE & 136 & 54,2 & 44,8 \\
FCS & 29 & 62,1 & 37,1 \\
FCHS & 43 & 67,5 & 32,5 \\
FCJE & 28 & 57,2 & 42,8 \\
\hline
\end{tabular}

Si bé en tots els centres enumerats la proporció femenina és més alta, uns en tenen més que altres. Així, la més feminitzada és la FCHS, on la diferència entre dones $i$ homes del pas és de 37 punts percentuals; li segueix la FCS, amb 35 punts. En sentit invers, les més equilibrades són l'Escola, amb tan sols 10 punts de diferència, seguida de la FCJE. El Rectorat manté una distància de 17 punts en la proporció entre els sexes, favorable també a les dones. 
Ara bé, tal com ja hem apuntat amb anterioritat, els llocs de nivell més elevat estan ocupats principalment per homes.

En els centres de serveis com ara la Càtedra Unesco, el Centre d'Estudis de Postgrau, l'Oficina de Cooperació, l'Oficina de Relacions Internacionals i l'Oficina d'Inserció Professional i Estades en Pràctiques, hi ha també majoria de dones. Només el Servei d'Esports inclou més homes que dones, si bé en una diferència ínfima: 15 homes i 12 dones.

\subsection{EL PAS PER GRUPS D'EDAT I SEXE}

A continuació incloem informació sobre l'edat del personal d'administració i serveis de l'UJI, en considerar que l'edat és una variable explicativa de màxima importància per al nostre estudi sobre la conciliació entre la vida familiar i laboral, ja que les necessitats respecte d'això varien en funció del cicle vital en què es trobe el treballador o treballadora, i això, en última instància, està relacionat amb l'edat.

Taula 14.

El PAs per grups d'edat el 2013

\begin{tabular}{lrcc} 
& Total & Dones \% & Homes \% \\
Menys de 30 anys & 32 & 53,1 & 46,9 \\
31-40 anys & 243 & 54,3 & 45,7 \\
41-50 anys & 267 & 61,8 & 38,2 \\
Més de 51 anys & 75 & 58,6 & 41,3 \\
\hline
\end{tabular}




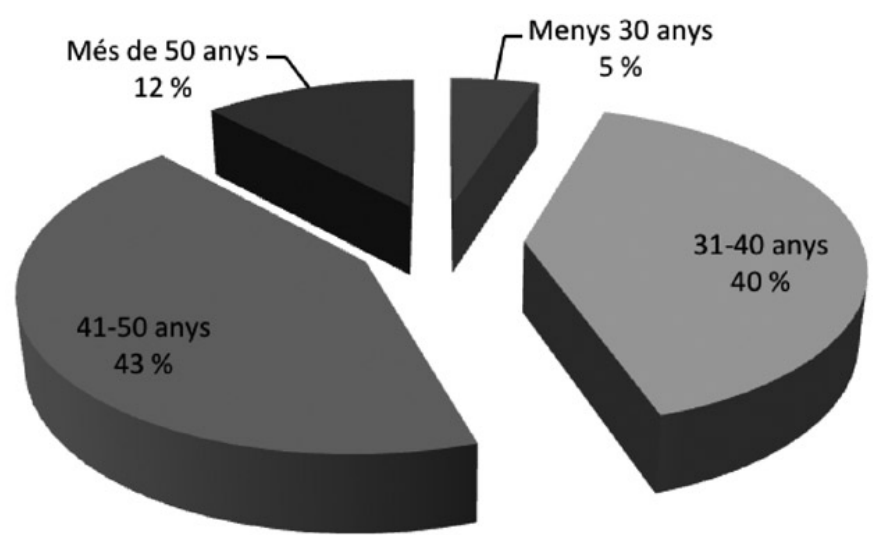

Gràfic 6.

Distribució del PAS per grups d'edat

Les dades ens indiquen que el $87,8 \%$ del pas de la Universitat Jaume I té menys de 50 anys, i que el 82,6\% té entre 30 i 50 anys. Considerem, doncs, que en el seu conjunt, és una població jove. 


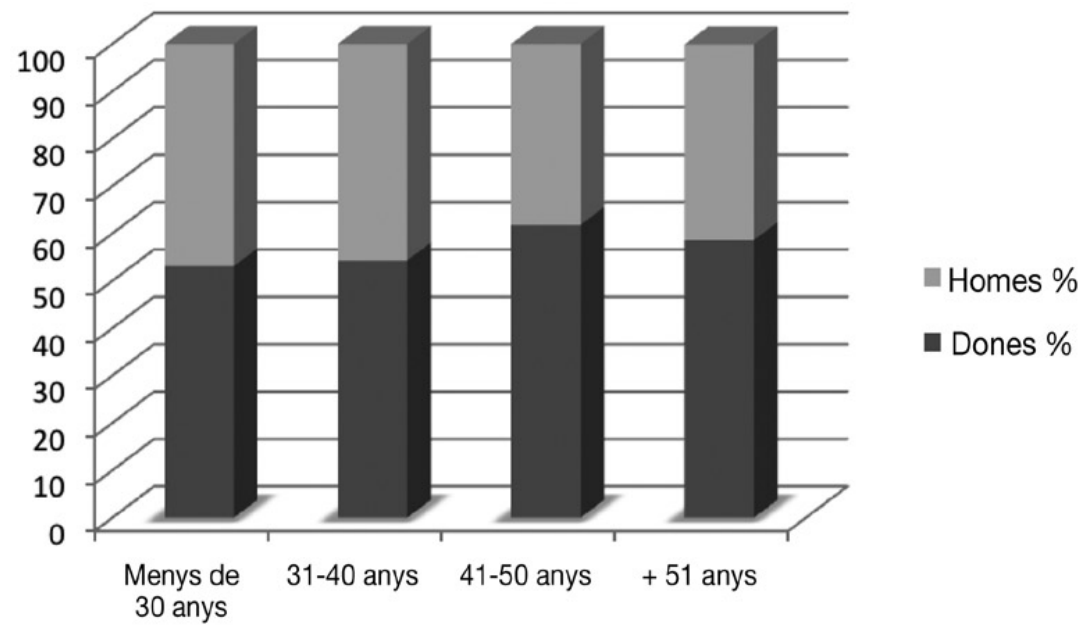

Gràfic 7.

Grups d'edat per sexe el 2013

Respecte a la distribució per sexe i grups d'edat, els grups més feminitzats són els de més edat, és a dir, els de més de 40 anys, mentre que els homes tenen més presència en els grups més joves.

Crida l'atenció que només hi haja 32 persones amb una edat inferior a 30 anys, en una situació pràcticament equilibrada entre dones i homes. El fet mostra el retard en la incorporació al mercat laboral de les noves generacions i el fre en la creació d'ocupació pública a causa de les retallades recents relacionades amb la crisi econòmica des de 2008.

El 1991 hi havia 36 persones menors de 30 anys, que representaven el 55,4 \% del total de PAs quan es va crear la Universitat. D'elles, el $61,1 \%$ eren dones i el 38,9\%, homes.

Comparant, doncs, la representació per sexe en el PAs en aquests dos anys, es conclou que al contrari del que veurem posteriorment en el PDI, la proporció d'homes s'ha incrementat en el PAS. 
D'altra banda, i des d'una altra lectura, com es veu en el gràfic següent, de les 352 dones PAs de l'usi, el 4,8 \% tenen menys de 30 anys; el 37,5\% tenen entre 31 i 40 anys; el 46,9\% es troben en el grup d'edat entre els $41 \mathrm{i}$ els 50 anys i 1'11,7\% tenen més de 51 anys.

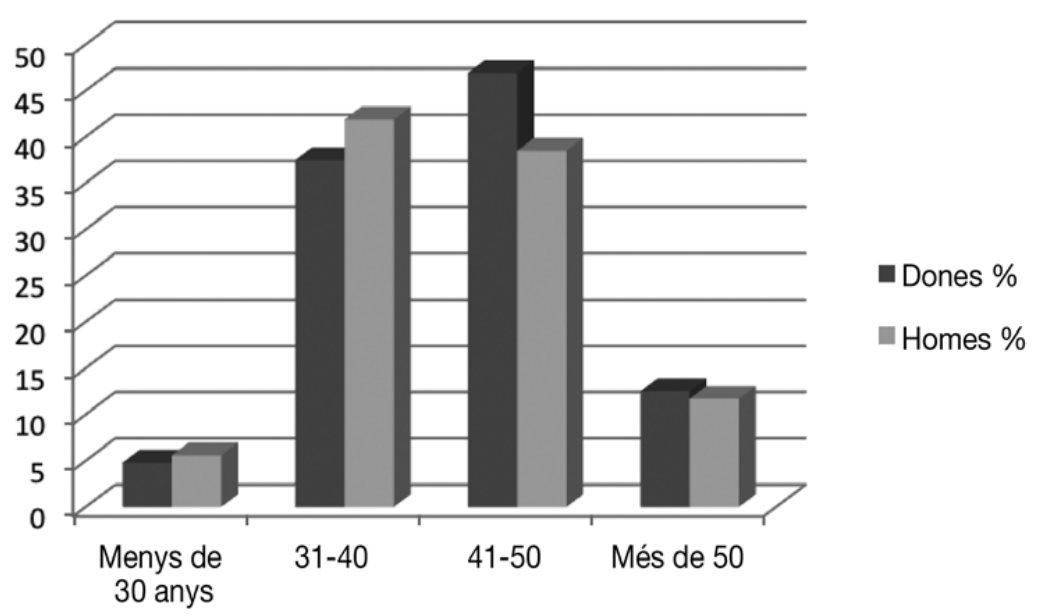

Gràfic 8.

Distribució per grups d'edat en les dones i en els homes del pas el 2013

\section{EL PERSONAL DOCENT I INVESTIGADOR DE LA UNIVERSITAT (PDI)}

El nombre de personal docent $\mathrm{i}$ investigador a la Universitat a data 1 octubre de 2013 és de 1.329 . D'aquesta xifra, 1.321 es distribueixen en quatre centres: la Facultat de Ciències Humanes i Socials, la Facultat de Ciències Jurídiques i Econòmiques, la Facultat de Ciències de la Salut, creada el 2011, i 1'Escola Superior de Tecnologia i Ciències Experimentals. Els 8 restants s'ubiquen a l'Institut Ceràmic i a l'edifici d'Investigació. 
Dels 1.329 PDI, el 43,5 \% són dones i el 56,5 \% són homes, per la qual cosa pot dir-se que la Universitat és equitativa pel que fa a la distribució entre els sexes, i supera la mitjana estatal, situada en un 38,8 \% de dones per al curs 2013/2014 (Dades bàsiques del sistema universitari espanyol, 2013).

Comparat amb el 1991, any de creació de l'UJI, amb una proporció del $31 \%$ de dones i $69 \%$ d'homes, la diferència és notable, ja que la proporció de dones PDI s'ha incrementat en 12 punts i mig percentuals. S'observa així una sostinguda tendència a l'alça cap a una major presència femenina a la Universitat, si bé encara hi ha diferències (Científicas en cifras, 2011).

Aquest increment del PDI femení es veu amb més claredat en el següent gràfic:

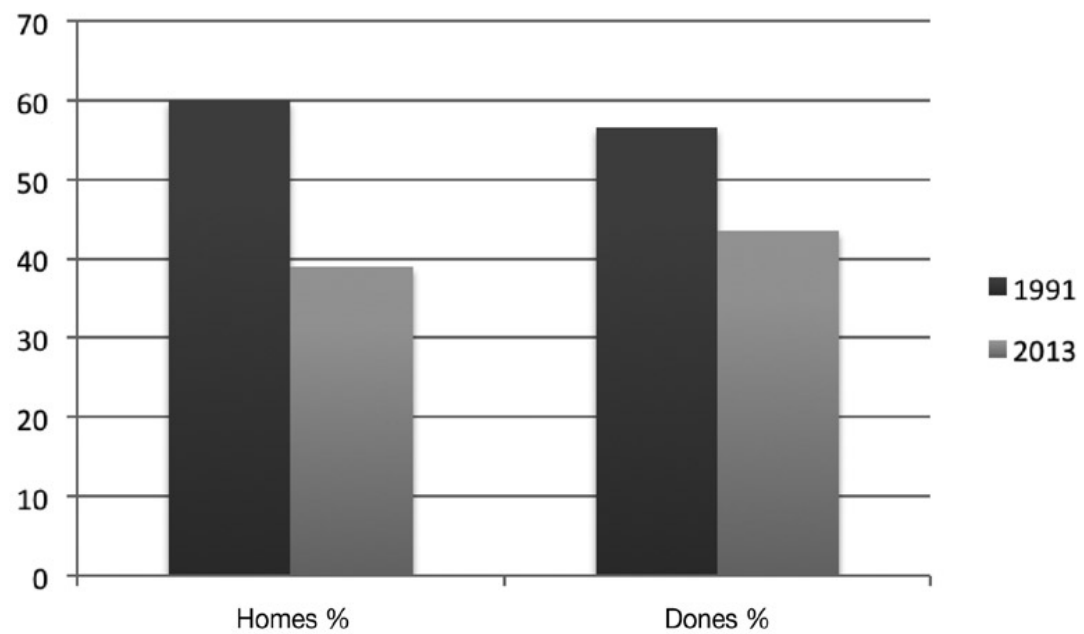

Gràfic 9.

Comparació de la distribució per sexes els anys 1991 i 2013 
L'estructura organitzativa de l'UJI es diversifica per al PDI en dos nivells. D'una part, en els òrgans de govern i representació, i d'una altra, en l'organització funcional, és a dir, en les diferents activitats que es realitzen a la Universitat, com ara els àmbits docents, investigadors i de serveis (Diagnòstic, 2009).

Els òrgans de govern, administració i representació s'estructuren, d'acord amb els Estatuts de l'UJI, en òrgans d'àmbit general i d'àmbit particular. Cada un d'aquests àmbits comprèn òrgans unipersonals $i$ òrgans col-legiats.

La distribució funcional de les unitats organitzatives de l'us s'estructura en facultats i escoles tècniques superiors, departaments, instituts d'investigació i en altres centres i estructures. En aquest sentit, la Universitat, fent ús de la seua autonomia organitzativa, pot crear o adscriure centres per a la realització de funcions docents, d'activitats de caràcter científic, tècnic, artístic o de prestació de serveis.

A continuació ens referirem en primer lloc a la distribució funcional del PDI en centres; en segon lloc, exposarem la distribució del PDI per categories professionals; en tercer lloc, ens centrarem en la distribució per edat del PDI, i en últim lloc, coneixerem la distribució dels llocs de direcció assumits pel PDI segons el sexe.

\subsection{DISTRIBUCIÓ DEL PDI PER SEXE I CENTRES}

Ens referim en primer lloc a la distribució funcional o segregació horitzontal, la qual ens indica la distribució del PDI per sexes en els quatre centres en què està organitzada la Universitat.

En la taula següent es reflecteix la distribució del PDI per centre i per sexe. Cal observar la diferent distribució que en relació als sexes tenen els centres: 
Taula 15.

Distribució PDI per centre i sexe el 2013

\begin{tabular}{lccc} 
& & Dones $\%$ & Homes $\%$ \\
ESTCE & 502 & 31,4 & 68,6 \\
FCHS & 349 & 51,0 & 49,0 \\
FCJE & 268 & 43,3 & 56,7 \\
FCS & 202 & 60,1 & 39,9 \\
\hline Total & $\mathbf{1 3 2 1}$ & $\mathbf{4 3 , 5}$ & $\mathbf{5 6 , 5}$ \\
\hline
\end{tabular}

La facultat més igualitària és la de Ciències Humanes i Socials (FCHS), pràcticament amb una distribució simètrica entre dones i homes. Li segueix la Facultat de Ciències Jurídiques i Econòmiques (FCJE), situada també en la proporció equilibrada, semblant a la de la Universitat en general. Finalment, trobem dos centres amb distribucions segregades: 1'Escola Superior de Tecnologia i Ciències Experimentals (ESTCE), amb una distribució clarament favorable als homes, i la Facultat de Ciències de la Salut (FCS), en la qual les dones són majoria, encara que està dins dels límits considerats com a equilibrats. ${ }^{69}$

En el curs 1991/1992, amb la posada en marxa de la Universitat, hi havia un clar predomini masculí en el professorat, ja que d'un total de 236 professors i professores, dues terceres parts del PDI eren homes. Així mateix, es contempla una clara segregació per sexe a l'Escola de Tecnologia i a la Facultat de Ciències Jurídiques i Econòmiques, i més equilibri a la Facultat de Ciències Humanes i Socials si bé encara amb un clar predomini masculí. La Facultat de Ciències de la Salut, no permet establir una comparació perquè es va crear l'any 2011.

69. Es considera que hi ha paritat quan la proporció entre els sexes està situada entre un 60/40. 
Taula 16.

Distribució del PDI per centre i sexe el 1991

\begin{tabular}{llll} 
& Total & Dones & Homes \\
ESCTE & 87 & $21,83 \%$ & $78,16 \%$ \\
FHHSS & 89 & $42,69 \%$ & $57,30 \%$ \\
FJJEE & 60 & $28,33 \%$ & $71,66 \%$ \\
\hline Total & $\mathbf{2 3 6}$ & $\mathbf{3 1 , 3 5 \%}$ & $\mathbf{6 8 , 6 4 \%}$ \\
\hline
\end{tabular}

En el següent gràfic s'observa amb més claredat la distribució per centre i per sexe.

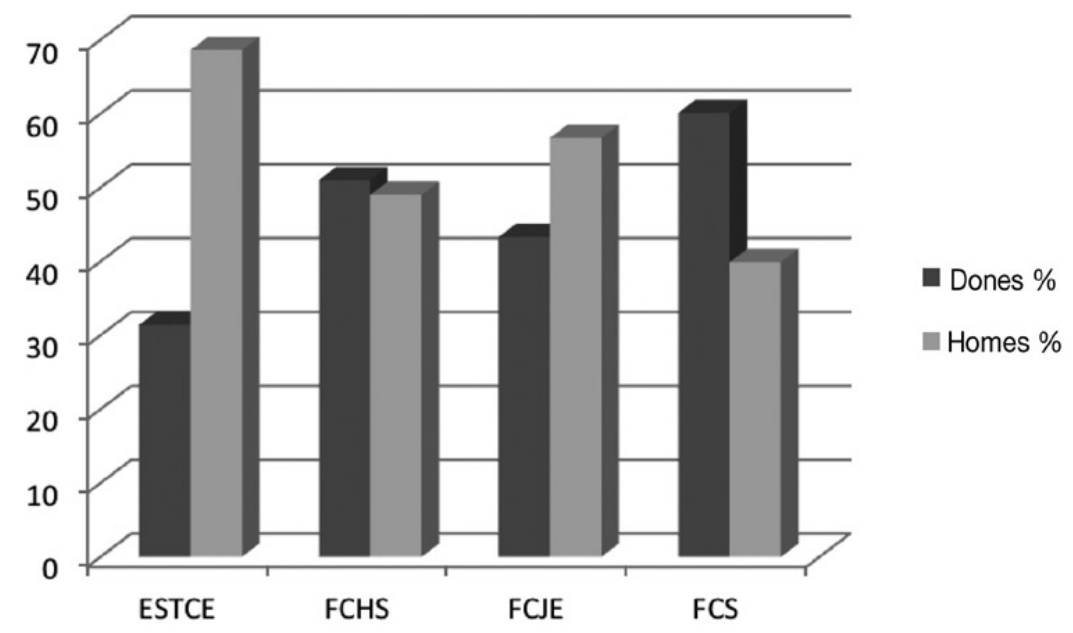

Gràfic 10.

Distribució PDI per centre i sexe el 2013 (\%) 


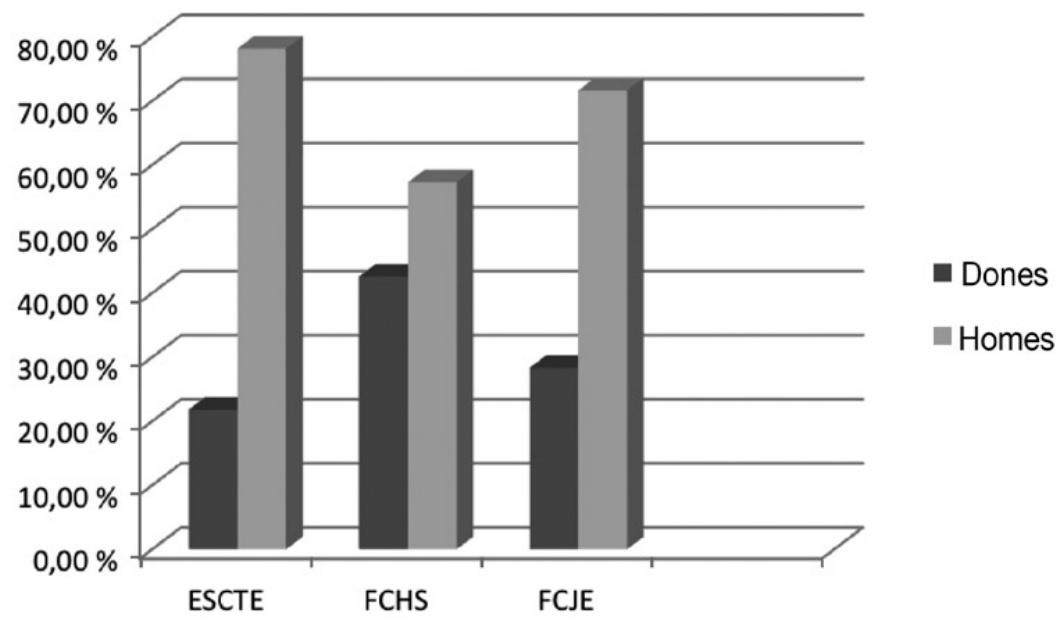

Gràfic 11.

Distribució del PDI per centres el 1991 (\%)

El gràfic anterior ens mostra la segregació horitzontal, és a dir, aquella que fa referència a la distribució per sexes en cada un dels centres. Es pot veure que s'aguditza la segregació masculina a l'Escola i la segregació femenina a la Facultat de Ciències de la Salut.

Comparant els anys 1991 i 2013, es manté la proporció més elevada masculina a 1'Escola i a la Facultat de Ciències Jurídiques i Econòmiques, i es produeix un canvi en la Facultat de Ciències Humanes $i$ Socials, en la qual s'ha incrementat la proporció de dones PDI, que és en l'actualitat superior al nombre d'homes PDI. La Facultat de Ciències de la Salut, última a crear-se, manté, com hem assenyalat en el paràgraf anterior, una proporció més alta de dones PDI.

Si bé, i com ja hem comentat amb anterioritat, s'ha incrementat la proporció de PDI a l'UJI en tots els centres, el fet més cridaner és l'increment en la participació femenina en 1'Escola, que ha sigut de 10 punts percentuals. 
Des del I Pla d'Igualtat de l'us (2010-2014) s'han implementat mesures per a combatre aquesta segregació tant masculina com femenina, fruit d'estereotips de gèneres que des de la infància influeixen en les adolescents i els adolescents a l'hora d'elegir uns tipus d'estudis o uns altres.

\subsection{CATEGORIES PROFESSIONALS DEL PDI PER SEXE}

En aquest punt presentem la distribució per categories professionals del PDI el 2013, la denominada segregació vertical, comparant-la posteriorment amb la distribució de 1991 tenint en compte els canvis en les categories professionals del professorat, molt més nombroses en el present per les distintes normatives reguladores de l'àmbit acadèmic que s'han anat aprovant entre els dos anys contemplats i que han variat les categories del PDI.

Taula 17.

Distribució PDI per categoria i sexe el $2013^{70}$

\begin{tabular}{lccc}
\hline & Total & Dones \% & Homes \% \\
CU & 118 & 20 & 80 \\
CEU & 5 & 60 & 40 \\
TU & 301 & 45,8 & 54,2 \\
TEU & 39 & 41 & 59 \\
$\begin{array}{l}\text { Contract, } \\
\text { doctor/a }\end{array}$ & 90 & 50 & 50
\end{tabular}

70. Cu (catedràtic/a d'universitat); CEU (catedràtic/a d'escola universitària); TU (titular d'universitat); TEU (titular d'escola universitària); Contractat doctor/a (contractat/ada doctor/a); collaborador/a; ajudant/a; investigador/a i associat/ada. 


\begin{tabular}{lccc}
\hline & Total & Dones \% & Homes \% \\
Col·laborador/a & 12 & 33,3 & 66,6 \\
Ajudant/a & 94 & 56,4 & 43,6 \\
Investigador/a & 218 & 49,5 & 50,5 \\
\hline Associat/ada & 442 & 40,5 & 59,5 \\
\hline
\end{tabular}

La taula mostra que hi ha simetria per categories entre els sexes excepte en la de catedràtics i catedràtiques, on la segregació és molt evident, ja que hi ha 23 catedràtiques d'un total de 118 catedràtics $i$ catedràtiques, la qual cosa suposa un $20 \%$ de dones catedràtiques, proporció lleugerament inferior a la mitjana estatal, que és del 20,3 \% (Dades bàsiques del sistema universitari espanyol, 2013). Es constata així, a pesar dels canvis esdevinguts en el conjunt de la societat i l'important creixement de la participació de les dones en l'àmbit universitari, la persistència de la discriminació en les categories superiors de la carrera acadèmica (Científicas en cifras, 2011).

D'altra banda, tenint en compte la relació jurídica que vincula el personal amb la Universitat, es verifica l'existència d'una proporció més elevada de personal funcionari masculí que femení excepte en la figura de les càtedres d'escola universitària.

En el següent gràfic s'observa amb més claredat aquesta distribució. 


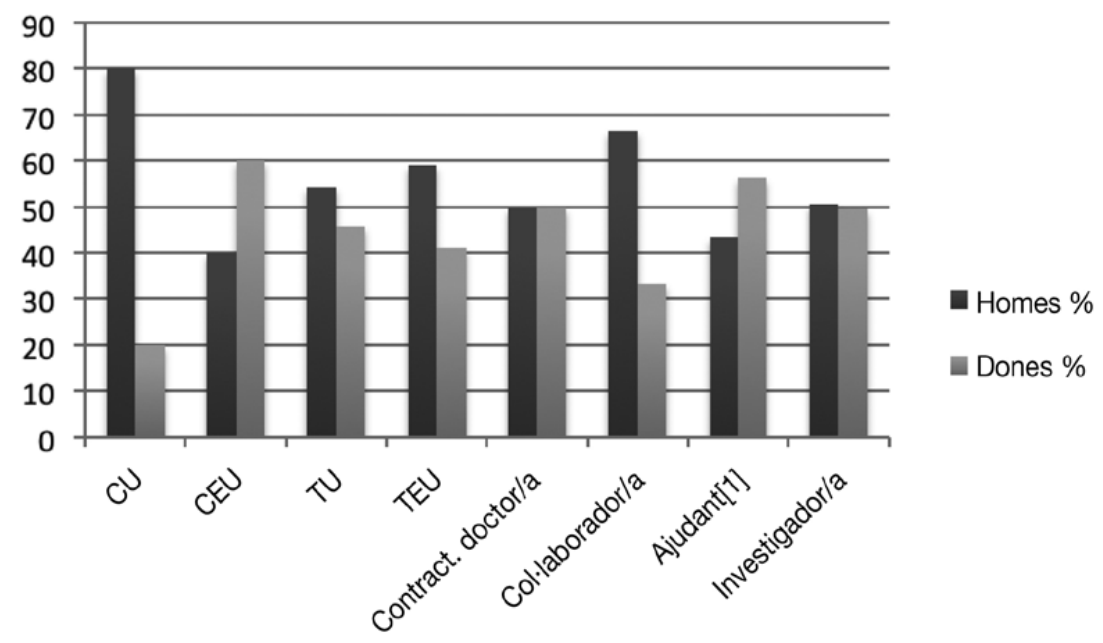

Gràfic 12.

Distribució del PDI per categoria laboral el 2013

És a dir, que pareix que hi ha un sostre de vidre que dificulta l'accés o promoció de les dones al nivell màxim de la carrera acadèmica, la càtedra, a pesar de l'increment tant d'estudiants com de docents dones en els últims anys.

En la literatura feminista acadèmica es defineix el sostre de vidre (glass ceiling) com aquell format per obstacles difícilment identificables que impedeixen les dones arribar a les posicions més altes en la jerarquia acadèmica universitària (Científicas en cifras, 2011).

Respecte a la figura de titular d'universitat, si bé encara hi ha més homes, les estimacions entren dins de les proporcions considerades com a equilibrades.

Ha de ressaltar-se que en la categoria d'investigador i investigadora la proporció és pràcticament semblant, la qual cosa denota una tendència igualitària en el sentit que les persones que opten a una plaça d'investigador o investigadora competeixen generalment en funció dels seus currículums, la qual cosa indica que les dones són igual de 
capaces que els seus companys i que la segregació vertical que posteriorment es produeix és deguda més aviat a qüestions socials i de discriminació de gènere que a qüestions de capacitació i preparació d'elles per a qualsevol disciplina, incloent-hi l'Escola de Tecnologia i Ciències Experimentals, on la proporció de personal investigador és del 53,3\% d'homes i el 46,6 \% de dones, totalment allunyada de les proporcions corresponents a les figures més consolidades.

El denominat sostre de vidre s'aplica clarament en aquest cas: la proporció de dones investigadores i ajudantes, és a dir, aquelles que comencen la seua carrera docent $i$ investigadora, és pràcticament semblant a la dels homes a mesura que s'ascendeix en la jerarquia acadèmica la proporció de dones minva.

Aquest fet va portar la investigadora Sandra Harding (1986) a preguntar-se per què les dones estan situades en els nivells d'inferior categoria, quins obstacles es troben en la seua carrera, i per què, eixint en el punt de partida en idèntica proporció que els homes, el punt d'arribada és tan diferent $i$ asimètric per a elles.

L'autora respon a la seua pregunta referint-se a la doble càrrega de treball que les dones normalment realitzen, així com al denominat sostre de vidre, a què hem al·ludit en paràgrafs anteriors

Respecte de la categoria d'associat i associada, la més nombrosa de la Universitat, la proporció és equilibrada, amb majoria d'homes. Les diferències entre els centres s'assemblen a les observades en l'anterior anàlisi: a l'Escola la proporció no és paritària (77,5\% d'homes enfront del 22,5\% de dones), a la Facultat de Ciències Jurídiques $i$ a la Facultat de Ciències Humanes la proporció és semblant i, finalment, a la Facultat de Ciències de la Salut la proporció és favorable a les dones però sense arribar a tenir la polarització que s'observa a 1'Escola.

Si comparem la distribució del PDI actual amb l'existent el 1991, a l'inici de la Universitat, les variacions són les següents: 
Taula 18.

Distribució per sexe i categoria el 1991

\begin{tabular}{lrcc} 
& Total & Dones \% & Homes \% \\
CU & 3 & & 100 \\
CEU & 5 & 20 & 80 \\
TU & 37 & 18,9 & 81,1 \\
TUI & 4 & 25 & 75 \\
TEU & 47 & 55 & 45 \\
TEUI & 105 & 34,3 & 65,7 \\
Ajudant/a EU & 4 & 25 & 75 \\
Associat/da & 30 & 6,7 & 93,3 \\
\hline
\end{tabular}

El 1991, i atès que la Universitat s'estava posant en marxa, el nombre de càtedres era escàs; ara bé, les poques que n'hi havia, foren d'universitat o d'escola universitària, estaven ocupades per homes.

El mateix passava amb les places de titular d'universitat, categoria que ha experimentat un gran creixement, tant en nombres absoluts com en la proporció de dones. Si el 1991 només el $20 \%$ dels TU eren dones, el 2013, tal com hem descrit en la taula anterior, el 45,84\% són dones.

És a dir, que en els 22 anys transcorreguts s'ha incrementat el nombre de dones titulars d'universitat en 25,84 punts, la qual cosa es podria considerar un èxit, si bé, és a partir d'ací quan comencen a aparèixer les barreres ocultes, el sostre de vidre, manifestades en el fet que en la categoria superior, la càtedra, aquest equilibri ja no es contemple.

L'única figura amb la més gran proporció de dones el 1991 és la figura de titular d'escola universitària (TEU), podria ser resultat de la 
incorporació de 1'Escola de Magisteri i de 1'Escola de Graduat Social a la Universitat Jaume I des de la seua creació, atès que el primer cas és un àmbit tradicionalment feminitzat.

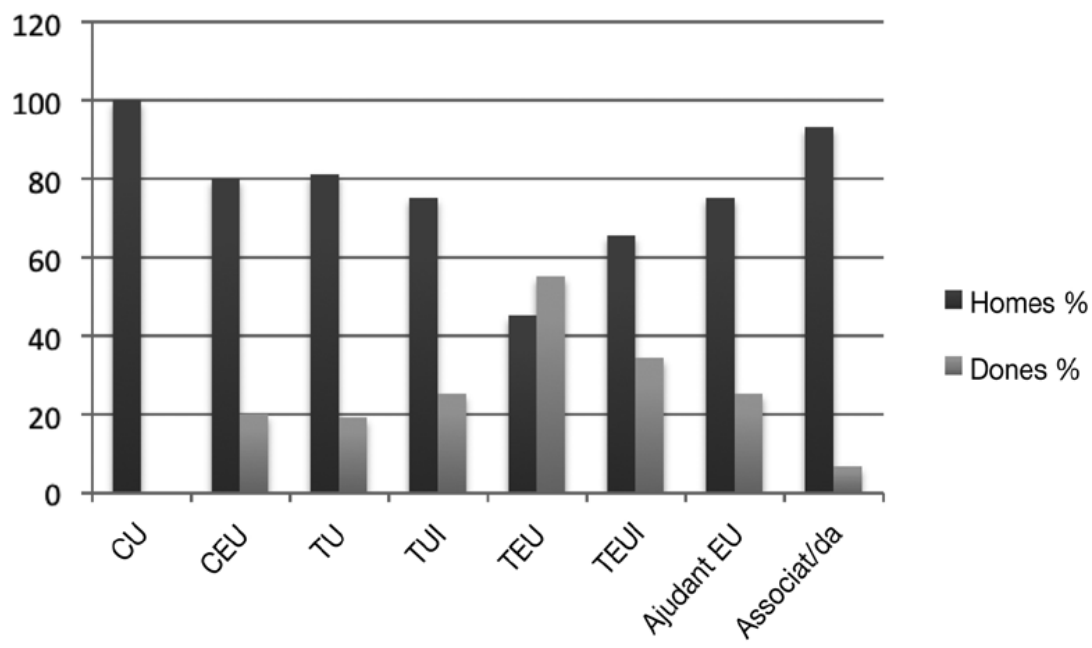

Gràfic 13 .

Distribució del PDI per categoria el 1991

Com hem pogut veure en els paràgrafs anteriors, l'UJI en els seus inicis era una universitat masculinitzada, aspecte que s'aguditzava encara més a 1'Escola Superior de Tecnologia i Ciències Experimentals, així com a la Facultat de Ciències Jurídiques i Econòmiques.

Atès que la segregació més elevada entre dones i homes es produeix en les càtedres, s'indica a continuació la seua distribució per centres per a conèixer si dins de la segregació vertical assenyalada es produeix també una segregació horitzontal: 
Taula 19.

Distribució de les càtedres per centres el $2013(\%)$

\begin{tabular}{lcc} 
& Dones & Homes \\
FCHS & 17,4 & 82,6 \\
FCJE & 33,3 & 66,6 \\
FCS & 36,4 & 63,6 \\
ESCTE & 10,5 & 89,4 \\
\hline
\end{tabular}

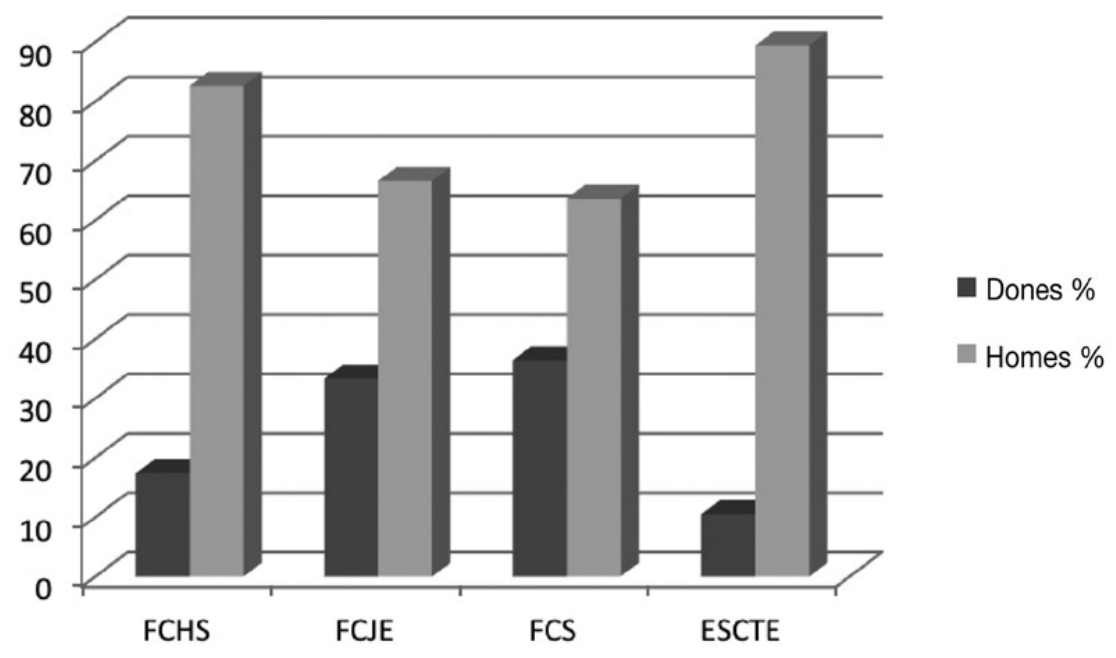

Gràfic 14.

Càtedres per centre i sexe el 2013

Comparant aquestes dades amb les de la taula 15, que inclou la distribució total del PDI per centres, és evident com en la cúspide de la carrera acadèmica les proporcions s'escoren en tots els centres cap als homes. Cap centre està equilibrat, ja que la proporció de catedrà- 
tics supera el $60 \%$ considerat com a límit. La més paritària respecte a les càtedres és la Facultat de Ciències de la Salut, la qual, segons s'ha comprovat, és també la més feminitzada dels quatre centres i la més recent a l'uJI.

La segregació respecte de les dones s'aguditza a l'Escola, on només el 10,5\% de les càtedres està ocupada per dones; sorprèn, d'altra banda, que en una facultat com la de Ciències Humanes i Socials, la més paritària de tots els centres, l'asimetria en les càtedres siga tan cridanera.

Contrastem les dades d'ocupació de les càtedres amb la informació sobre les figures d'ajudant i ajudanta $\mathrm{i}$ investigador i investigadora, considerades com l'inici de la carrera acadèmica i investigadora a la Universitat per a veure, tal com assenyalàvem en un paràgraf anterior, les diferències en la situació de partida i en la situació d'arribada.

Taula 20.

Distribució del personal ajudant i investigador en els centres el 2013 (\%)

\begin{tabular}{lcccc} 
& \multicolumn{2}{c}{ Ajudant/a } & \multicolumn{2}{c}{ Investigador/a } \\
& Dones & Homes & Dones & Homes \\
FCHS & 63,3 & 36,6 & 41,2 & 58,8 \\
FCJE & 73,3 & 26,6 & 44,5 & 55,5 \\
FCS & 66,6 & 33,3 & 68,9 & 31,1 \\
ESTCE & 38,2 & 61,8 & 46,7 & 53,3 \\
\hline
\end{tabular}

Les dades indiquen una diferència important en el sexe del personal ajudant $\mathrm{i}$ del personal investigador: en el primer predominen les dones excepte a l'Escola, que com ja sabem és el centre més masculinitzat, mentre que en el segon, el personal investigador, predominen 
els homes, excepte a la FCS, el centre més feminitzat, on són les dones les que més representació tenen.

En els dos gràfics següents, on es reflecteix la proporció de dones i homes en les dues figures contemplades, es constata la diferència entre l'una i l'altra.

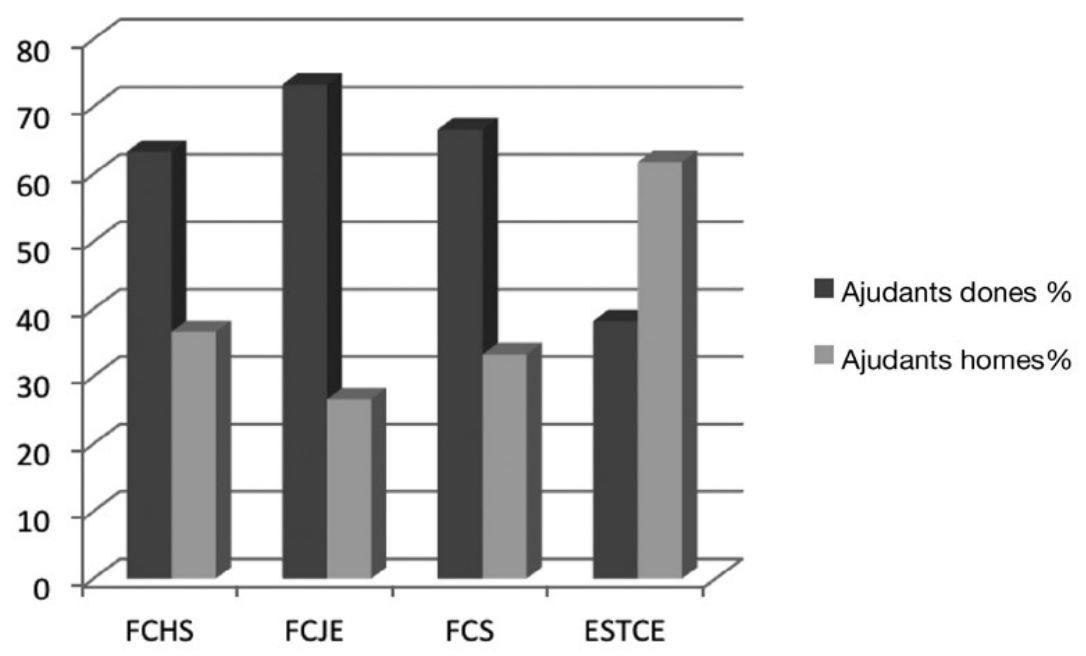

Gràfic 15.

Personal ajudant per sexe el 2013 


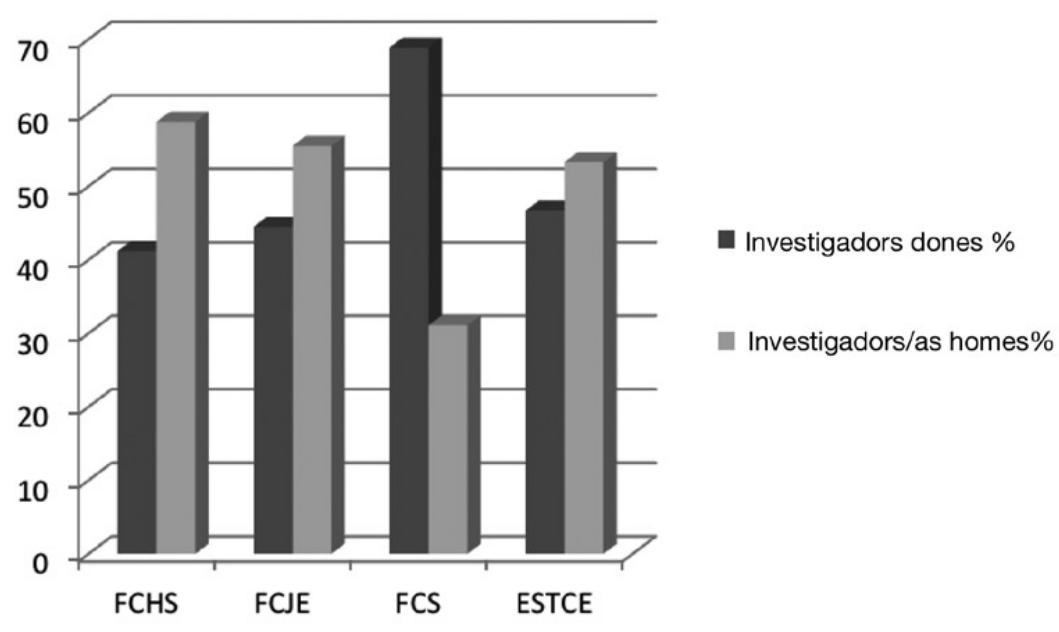

Gràfic 16.

Personal investigador per sexe el 2013

\subsection{EL PDI PER GRUPS D’EDAT I SEXE}

En tercer lloc, farem una breu referència a l'edat del PDI de la Universitat, ja que considerem que s'ha produït un canvi generacional important respecte a les dones en relació amb els canvis legals, polítics i culturals i que si això és així, també es veuran reflectits en la distribució per edats a la Universitat.

A més, l'edat és una variable central en les necessitats i demandes respecte a la conciliació de la vida laboral i familiar, per la qual cosa considerem imprescindible per al nostre estudi referir-nos a aquesta dada.

E1 2013, el 76,8 \% tenia menys de 51 anys. En el següent gràfic es pot veure la distribució del PDI per grups d'edat. 


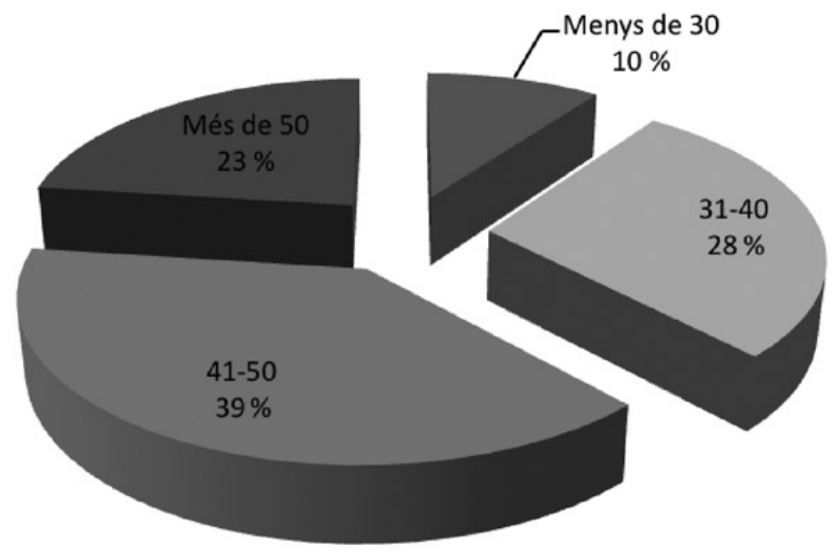

Gràfic 17.

PDI per grups d'edat

Com que és una universitat jove, el PDI també ho és. En l'actualitat, el 76,8 \% del personal docent $\mathrm{i}$ investigador té menys de 51 anys. La franja d'edat més nombrosa és la de 41-50 anys, que representa quasi un $40 \%$ del total, i constitueix, al costat de la franja de 31-40 anys, el $67 \%$ del conjunt del PDI.

La següent taula mostra la distribució del personal docent i investigador per grups d'edat i sexe.

Taula 21.

Distribució del PDI per edat i sexe

\begin{tabular}{lccc} 
& Total & Dones \% & Homes \% \\
Menys de 30 anys & 128 & 64,8 & 35,2 \\
$31-40$ anys & 373 & 49,1 & 50,9 \\
41-50 anys & 514 & 43,9 & 56,1 \\
Més de 51 anys & 306 & 30,1 & 69,9 \\
\hline
\end{tabular}


Les dades de l'anterior taula es reflecteixen amb més claredat en el següent gràfic.

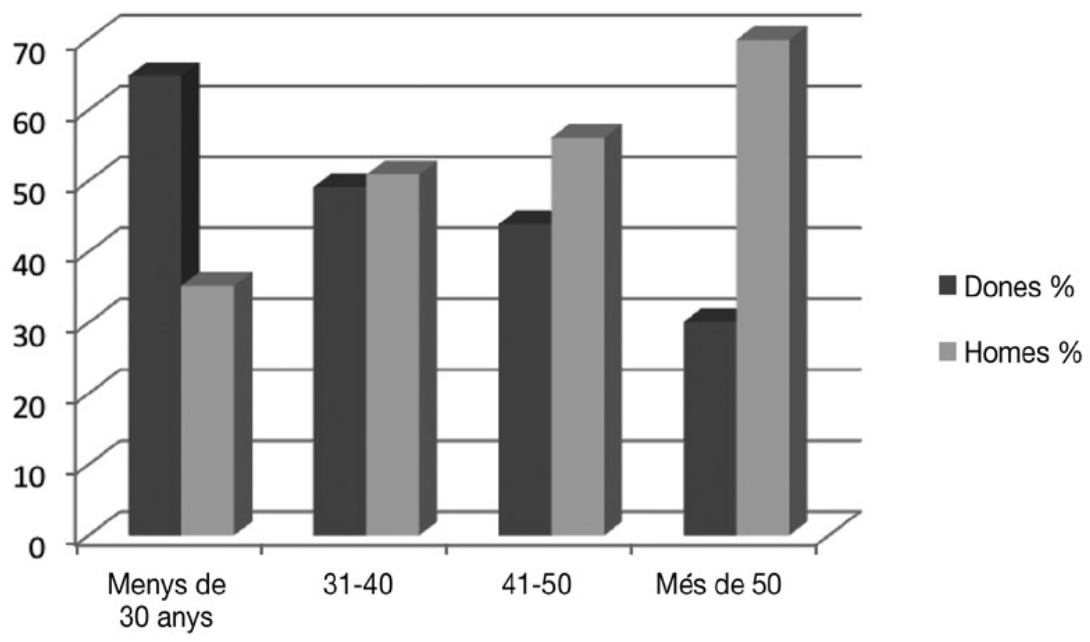

Gràfic 18.

Distribució del PDI per edat i sexe

Els resultats exposats mostren una feminització en el grup de menys de 30 anys, que ocupen, en principi, places menys consolidades; el grup de 31 a 40 anys pot considerar-se paritari; i, a partir dels 40 anys, la masculinització és notable, i s'aguditza a partir dels 50 anys.

El fet de la masculinització del PDI a partir dels 40 anys, tenint en compte que en anys anteriors la proporció és paritària o favorable a les dones, pot interpretar-se de dues maneres si apliquem la perspectiva del gènere: en primer lloc, com la conseqüència del major pes que les dones tenen en les tasques domèstiques i d'atenció, especialment amb l'arribada de criatures, que fa que alentisquen o es dediquen amb menys intensitat a les tasques acadèmiques; i, en segon lloc, i 
en aquest cas per a aquelles dones de més de 50 anys, a la inferior participació acadèmica de les dones d'aquesta generació com a conseqüència de la seua menor presència en l'educació superior i de la prioritat del rol tradicional de gènere femení, el qual adjudicava a les dones les cures familiars i les tasques domèstiques.

Vegem a continuació si la distribució per grups d'edat i sexe és igual en tots els centres o hi ha diferències entre ells.

Taula 22.

Distribució del PDI per edat, sexe i centre el 2013. (Verticals)

\begin{tabular}{lrrrrrrrrr} 
& \multicolumn{2}{c}{ Menys de 30 anys } & \multicolumn{2}{c}{$\mathbf{3 1 - 4 0}$ anys } & \multicolumn{2}{c}{$\mathbf{4 1 - 5 0}$ anys } & \multicolumn{2}{c}{ Més de 51 anys } \\
& Dona & Home & Dona & Home & Dona & Home & Dona & Home \\
ESCTE & 43,3 & 75,5 & 30,5 & 53,2 & 25,6 & 49,6 & 15,2 & 27,6 \\
FCHS & 25,3 & 6,6 & 33,3 & 20,0 & 27,9 & 19,4 & 44,5 & 31,7 \\
FCJE & 9,6 & 13,3 & 18,6 & 12,7 & 26,1 & 24,3 & 16,3 & 24,7 \\
FCS & 21,7 & 4,4 & 18,0 & 14,2 & 20,3 & 6,6 & 23,9 & 15,9 \\
\hline Total & $\mathbf{8 3}$ & $\mathbf{4 5}$ & $\mathbf{1 8 3}$ & $\mathbf{1 9 0}$ & $\mathbf{2 2 6}$ & $\mathbf{2 8 8}$ & $\mathbf{9 2}$ & $\mathbf{2 1 4}$ \\
\hline Total & & $\mathbf{1 2 8}$ & & $\mathbf{3 7 3}$ & & $\mathbf{5 1 4}$ & \multicolumn{3}{|c}{$\mathbf{3 0 6}$} \\
\hline
\end{tabular}

Les persones de menys de 30 anys tenen més presència a l'Escola, majoritariament dones, i la distribució per centres és semblant a la de la resta de grups: proporció més elevada d'homes a l'Escola i a la FCJE i més presència de dones a la FCS i la FCHS.

Les persones amb edats entre els $31 \mathrm{i}$ els 40 anys tenen una representació quasi paritària igual que la seua distribució per centres, excepte a l'Escola, on els homes superen les dones en 22 punts percentuals. 
El mateix ocorre amb el grup del PDI amb edats entre els 41 i els 50 anys, si bé la diferència entre dones i homes a l'Escola se situa en 24 punts percentuals a favor dels homes, mentre que a la FCS és al revés, les dones superen els homes en quasi 14 punts.

Finalment, en el grup de persones amb més de 50 anys les diferències es mantenen semblants. Dos centres, l'Escola i la FCJE, tenen més presència masculina $i$ els altres dos, la FCHS i la FCS, mantenen una presència femenina més elevada.

En els gràfics següents es pot observar la distribució per grup d'edat.

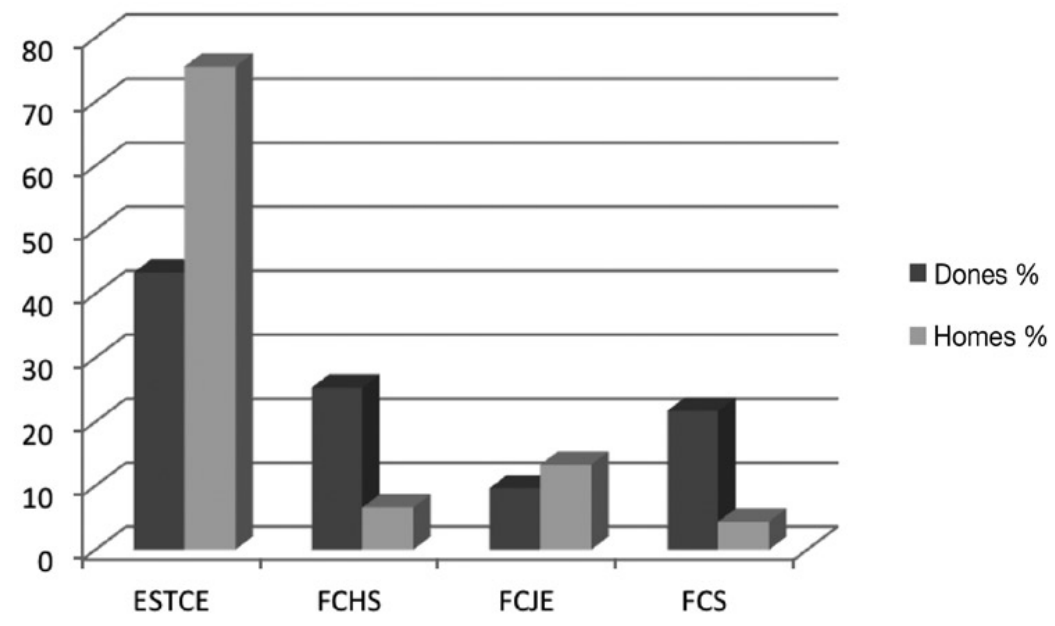

Gràfic 19.

Distribució del PDI menor de 30 anys per centre i sexe 


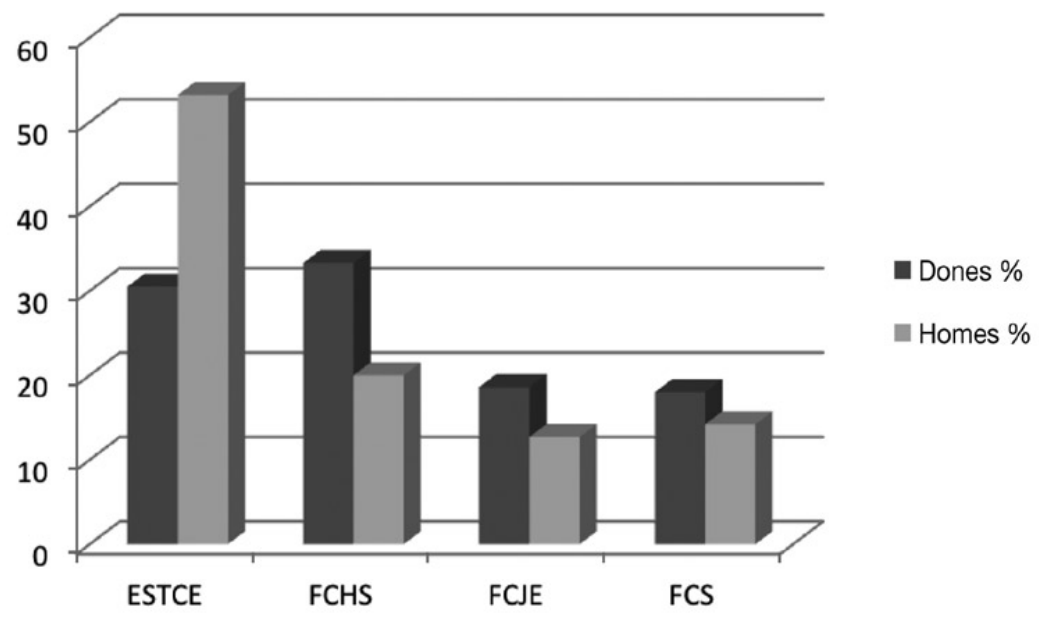

Gràfic 20.

Distribució del PDI entre 31 i 40 anys per centre i sexe

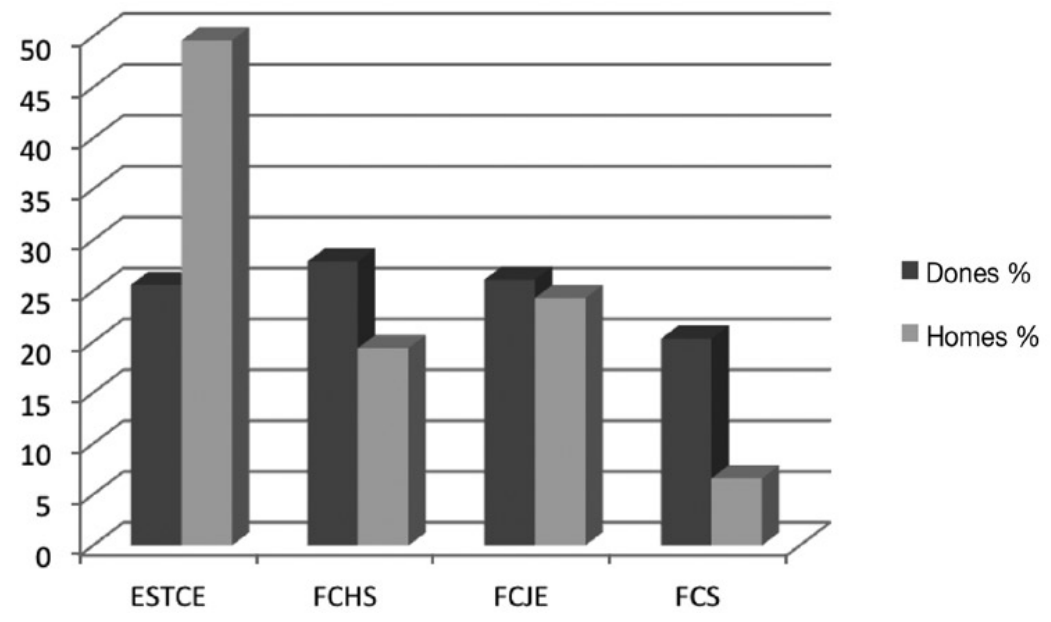

Gràfic 21.

Distribució del PDI entre 41 i 50 anys per centre i sexe 


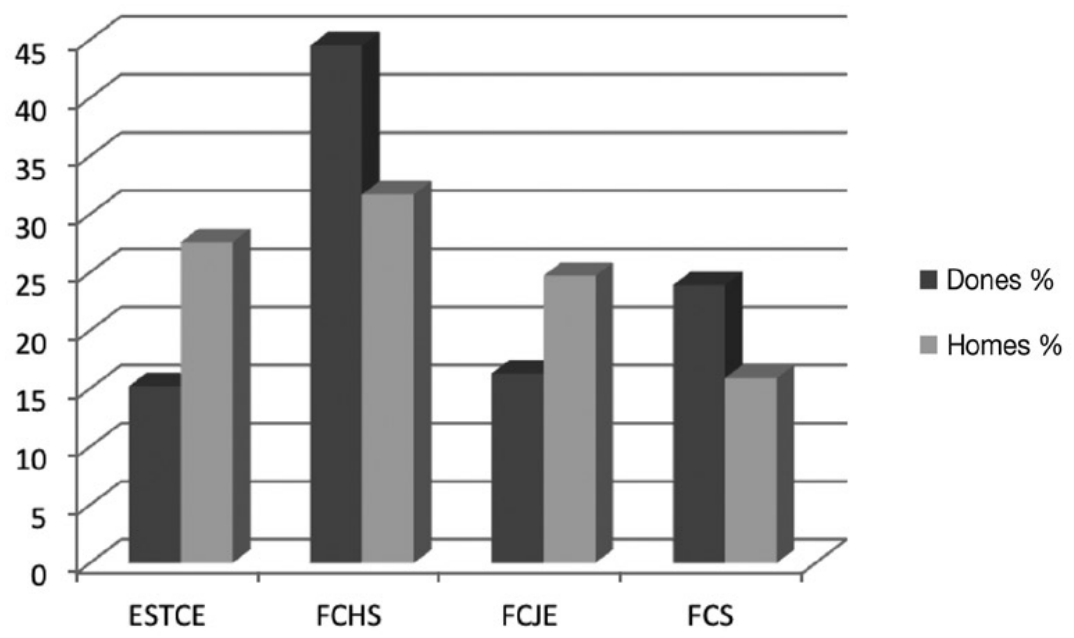

Gràfic 22 .

Distribució del PDI de més de 51 anys per centre i sexe

\subsection{DISTRIBUCIÓ DEL PDI SEGONS ÒRGANS DE DIRECCIÓ EN 2013}

En últim lloc, tal com hem assenyalat amb anterioritat, l'estructura organitzativa de l'Us inclou també els òrgans de direcció. En la següent taula s'exposa la distribució per sexe dels càrrecs/llocs de responsabilitat unipersonals de la Universitat. 


\section{Taula 23.}

Distribució dels càrrecs de responsabilitat per sexe el 2013

\begin{tabular}{lcc} 
& Dones & Homes \\
Rectorat & 1 & 1 \\
Secretaria General & & \\
Gerència & 1 & 1 \\
Sindicatura de Greuges & 3 & 5 \\
Vicerectorats & 2 & 2 \\
Deganats/Direcció & 1 & 3 \\
Secretaria de centres & 10 & 17 \\
Direcció de departament & 14 & 13 \\
Secretaria de departament & & \\
\hline
\end{tabular}

Els quatre primers càrrecs són unipersonals.

En la resta, la direcció de departament està representada en el $63 \%$ dels casos per homes i en els vicerectorats la proporció de vicerectores representa el $40 \%$. Els deganats i la direcció de centres mostren una proporció paritària i el mateix ocorre amb les secretaries de departament on el 51,8 \% són dones i les secretaries de centre, on la proporció és del $75 \%$.

Respecte als canvis succeïts, és necessari dir que el 1991, de les nou unitats predepartamentals que hi havia en aquella data, totes estaven dirigides per homes (Fenollosa, 1992), i estaven assumides les secretaries d'aquestes només en dos casos per dones. És a dir, que de 1991 a 2013 s'ha passat d'una proporció del $100 \%$ de directors de departament a un $63 \%$ actualment. Respecte a les secretaries, s'ha passat d'un $22,2 \%$ de secretàries de departament a representar un poc més del $50 \%$. 


\section{CONCLUSIONS}

Dins dels dos col-lectius de treballadors i treballadores de la Universitat Jaume I es presenta una diferenciació pel que fa a la distribució per sexe: en el PAs predominen les dones i en el PDI els homes.

Ara bé, entre els dos anys estudiats, 1991 i 2013, s'ha produït un canvi en els dos col-lectius invers pel que fa a la proporció dels sexes: s'ha incrementat el percentatge d'homes en el PAs i el de dones en el PDI.

\section{Taula 24.}

Distribució per sexe i categoria laboral en els anys 1991 i 2013

\begin{tabular}{lcccc} 
& \multicolumn{2}{c}{1991} & \multicolumn{2}{c}{$\mathbf{2 0 1 3}$} \\
& Dones \% & Homes \% & Dones \% & Homes \% \\
\hline PAS & 64,6 & 35,4 & 59,0 & 41,0 \\
PDI & 31,0 & 69,0 & 43,5 & 56,5 \\
\hline
\end{tabular}

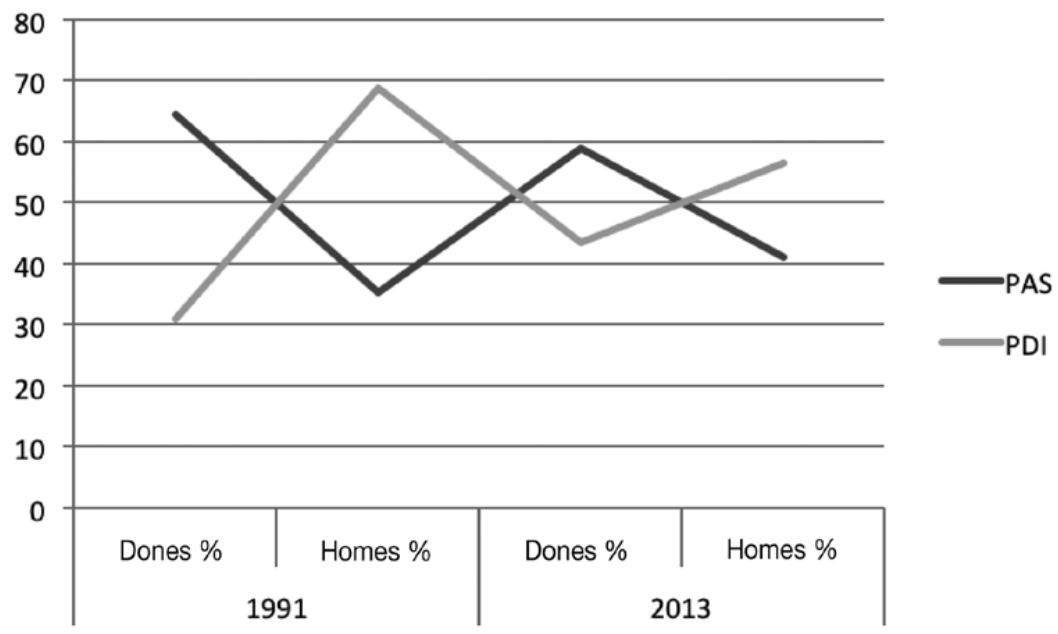

Gràfic 23.

Evolució del PAs i del PDI en els anys 1991 i 2013 
Aquest canvi de tendència no ha suposat un canvi semblant pel que fa als llocs de direcció en el PAS o de càtedres en el PDI, que continuen sent eminentment masculines.

És a dir, i com hem anunciat al llarg del capítol, el sostre de vidre continua estant present $i$ caldria incidir en els mecanismes que frenen l'accés de més dones als dits llocs per mitjà d'accions tendents a aconseguir més paritat.

En el cas del PAs, i segons dades proporcionades pel Diagnòstic de 2009 (www.ui.uji.es), hi ha una àmplia majoria de dones amb titulació universitària, fet que ens informa de l'existència del fenomen de subqualificació femenina en l'Administració com a conseqüència d'una discriminació laboral que perjudica clarament les dones o, com assenyala Rivero Recuenco (2005), com una estratègia de conciliació utilitzada per les dones consistent a ocupar llocs de treball d'inferior categoria i menor responsabilitat per a així poder realitzar amb més facilitat el treball de «fora» i el de «dins».

En el cas del PDI, caldria analitzar amb més profunditat els motius pels quals es paralitza de manera més usual la carrera acadèmica de les dones que la dels homes, considerant que, com s'ha exposat en pàgines anteriors, les dones opten a llocs de personal investigador $\mathrm{i}$ ajudant en proporció quasi paritària amb els homes.

Si els mecanismes de fre es deuen al nivell de responsabilitat més alt que tenen les dones en les tasques d'atenció i domèstiques caldrà realitzar esforços en l'àmbit de la societat en general, i de la Universitat en particular, perquè la coresponsabilitat en l'exercici de tasques domèstiques i d'atenció es generalitze entre els homes. 


\section{CAPÍTOL IV \\ LA CONCILIACIÓ DE LA VIDA LABORAL \\ I FAMILIAR A LA UNIVERSITAT JAUME I}

\section{NORMATIVA I MESURES EN MATÈRIA DE CONCILIACIÓ: CONEIXEMENT I ÚS A LA UNIVERSITAT JAUME I}

I niciem l'exposició dels resultats de l'enquesta realitzada a una mostra de treballadors i treballadores de la Universitat Jaume I matives legals relatives a la conciliació de la vida laboral, familiar i personal i de les mesures incloses en el I Pla d'Igualtat de l'UJI.

Per a una major operativitat exposarem, en primer lloc, les dades relacionades amb el PAS, en segon lloc amb el PDI i, finalment, realitzarem una comparativa entre les dades dels dos col·lectius.

\subsection{EL PERSONAL D’ADMINISTRACIÓ I SERVEIS (PAS)}

\subsubsection{Coneixement de la normativa i del I Pla d'Igualtat de l'UJI}

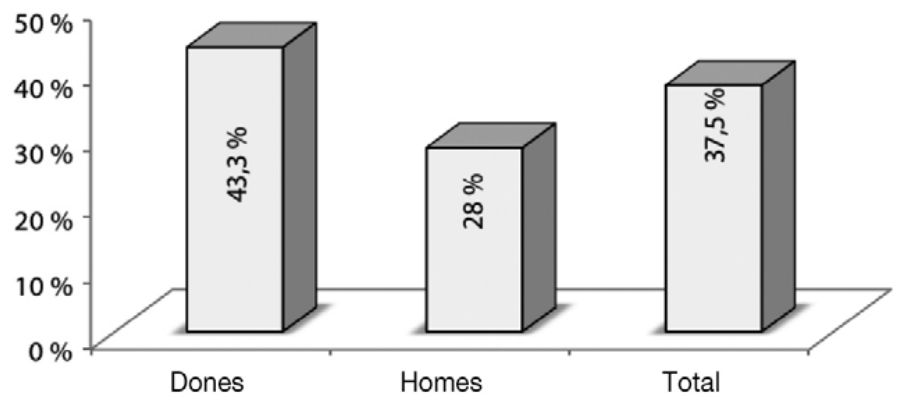

Gràfic 1 .

Coneixement de la legislació en matèria de conciliació 
Les dades reflecteixen, en termes generals, que hi ha desconeixement sobre la normativa relativa a la conciliació de la vida laboral, familiar i personal entre el PAS de la Universitat Jaume I. Si realitzem l'anàlisi desagregant per sexe, les dones coneixen més la normativa legal en matèria de conciliació que els homes $(43,3 \%$ de les dones enfront del $28 \%$ dels homes), aspecte que també es manté, com es veurà més endavant, en el coneixement de les mesures concretes en matèria de conciliació.

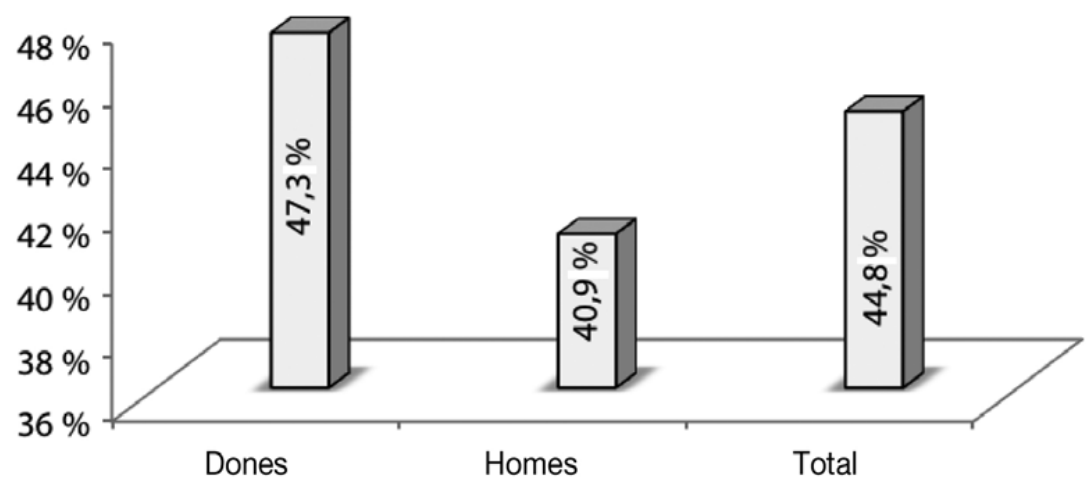

Gràfic 2.

Coneixement del I Pla d'Igualtat de la Universitat Jaume I

En el cas del coneixement de l'existència del I Pla d'Igualtat de la Universitat Jaume I s'observa un equilibri respecte a homes i dones: el coneixen el 40,9 \% dels homes i el 47,3\% de les dones. No obstant això, aquests percentatges indiquen que tant elles com ells desconeixen que la Universitat Jaume I té recollides un conjunt de mesures i estratègies per a facilitar la conciliació de la vida familiar, laboral i personal i aconseguir la igualtat efectiva de dones i homes dins de l'àmbit de la Universitat Jaume I, compilades en el I Pla d'Igualtat. 
Per tant, l'anàlisi evidencia que el col·lectiu PAS de l'UJI desconeix tant la legislació en matèria de conciliació general, com el I Pla d'Igualtat de la Universitat, en particular. No obstant això, cal assenyalar que desagregant per sexe el grau de coneixement és semblant en les dues qüestions en el grup de les dones (47,3\% coneixen el I Pla d'Igualtat i 43,3\% la normativa general), mentre que en els homes s'incrementa el coneixement sobre el I Pla d'Igualtat (40,9 \% i 28 \%, respectivament), probablement perquè és una normativa més pròxima i que inclou les mesures concretes per al seu entorn laboral.

\subsubsection{Coneixement i ús de les distintes mesures de conciliació per part del PAS}

A continuació es presenten dues taules en què s'incorporen, ordenades de major a menor valor obtingut, les mesures de conciliació de la vida laboral/vida familiar/vida personal emmarcades en el I Pla d'Igualtat de l'us. La primera fa referència al coneixement de les mesures i la segona, al seu ús. Ambdues estan desagregades per sexe.

Taula 1.

PAs que coneix cada una de les distintes mesures de conciliació, per sexe. Percentatge sobre el col-lectiu de referència

$\begin{array}{lccc}\text { Mesura coneguda } & \text { Total } & \text { Dones } & \text { Homes } \\ \begin{array}{l}\text { Permís per intervenció quirúrgica de } \\ \text { familiars o malaltia greu d'un familiar }\end{array} & 87,9 \% & 92 \% & 81,7 \% \\ \begin{array}{l}\text { Permís de maternitat/paternitat o permís } \\ \text { d'adopció o acolliment }\end{array} & 83,9 \% & 90,7 \% & 74,2 \% \\ \begin{array}{l}\text { Permís de lactància o acumulació } \\ \text { d'hores de lactància }\end{array} & 81 \% & 88,7 \% & 69,9 \% \\ \end{array}$




\section{Mesura coneguda}

Permís per a visites mèdiques $\mathrm{i}$

assistència a persones menors, ancianes

i amb discapacitat

Adaptació/reducció de jornada per

atenció a menors de fins a 12 anys

Excedència per atenció a menors o familiars a càrrec seu

Adaptació/reducció de jornada per convivència amb l'atenció directa a una persona amb discapacitat

Reducció/permís/excedència per violència de gènere

Adaptació/reducció de jornada per atenció a fill/a menor amb malaltia greu que implique hospitalització de llarga duració

Flexibilitat horària en la jornada laboral per guarda legal de menors o familiars que requerisquen dedicació especial

Adaptació/reducció de jornada per atenció directa a familiar de fins a segon grau, que per edat, accident o malaltia no puga valdre's per si mateix i no exercisca activitat retribuïda

Reducció de la jornada per malaltia llarga o crònica que impedisca la realització de la jornada completa

Preferència en l'accés als cursos de formació del PAS

\section{Total Dones Homes}

$74,2 \% \quad 81,3 \% \quad 64,5 \%$

$74,2 \% \quad 82 \% \quad 63,4 \%$

$70,6 \% \quad 80,7 \% \quad 57 \%$

$61,3 \% \quad 66 \% \quad 54,8 \%$

$58,1 \% \quad 67,3 \% \quad 44,1 \%$

$55,6 \% \quad 61,3 \% \quad 47,3 \%$

$52,4 \% \quad 60 \% \quad 41,9 \%$

$50,8 \% \quad 56 \% \quad 44,1 \%$

$50,4 \% \quad 52,7 \% \quad 47,3 \%$

$22,2 \% \quad 20,7 \% \quad 24,7 \%$ 
Taula 2.

Pas que usa cada una de les distintes mesures de conciliació, per sexe. Percentatge sobre el col·lectiu de referència

\section{Mesura usada}

Permís per intervenció quirúrgica de familiars o malaltia greu familiar

Permís de maternitat/paternitat o permís d'adopció o acolliment

Permís per a visites mèdiques $\mathrm{i}$ assistència a persones menors, ancianes i amb discapacitat

Permís de lactància o acumulació d'hores de lactància

Adaptació/reducció de jornada per atenció a menors de fins a 12 anys

Excedència per atenció a menors 0 familiars a càrrec seu

Preferència en l'accés als cursos de formació del PAS

Flexibilitat horària en la jornada laboral per guarda legal de menors o familiars que requerisquen dedicació especial

Adaptació/reducció de jornada per atenció directa a familiar de fins a segon grau, que per edat, accident o malaltia no puga valdre's per si mateix i no exercisca activitat retribuïda

Adaptació/reducció de jornada per convivència amb l'atenció directa a una persona amb discapacitat

\section{Total Dones Homes}

$63,7 \% \quad 70 \% \quad 53,8 \%$

$51,2 \% \quad 58,7 \%$

$39,8 \%$

$48 \% \quad 57,3 \% \quad 34,4 \%$

$35,1 \% \quad 51,3 \%$

$9,7 \%$

$16,1 \% \quad 24 \% \quad 4,3 \%$

$14,1 \% \quad 22 \% \quad 2,2 \%$

$7,3 \% \quad 9,3 \% \quad 4,3 \%$

$5,2 \% \quad 6 \% \quad 4,3 \%$

$2 \% \quad 2,7 \% \quad 1,1 \%$

$1,6 \% \quad 2 \% \quad 1,1 \%$ 


\begin{tabular}{lccc} 
Mesura usada & Total & Dones & Homes \\
$\begin{array}{l}\text { Reducció de la jornada per malaltia } \\
\text { llarga o crònica que impedisca la } \\
\text { realització de la jornada completa }\end{array}$ & $0,8 \%$ & $0 \%$ & $2,2 \%$ \\
$\begin{array}{l}\text { Adaptació/reducció de jornada per } \\
\text { atenció a fill/a menor amb malaltia greu } \\
\text { que implique hospitalització de llarga } \\
\text { duració }\end{array}$ & $0 \%$ & $0 \%$ & $0 \%$ \\
$\begin{array}{l}\text { Reducció/permís/excedència per } \\
\text { violència de gènere }\end{array}$ & $0 \%$ & $0 \%$ & $0 \%$ \\
\hline
\end{tabular}

A continuació, s'analitzen les dades presentades en les taules.

En relació amb el coneixement de les mesures cal citar que totes són conegudes per damunt del $50 \%$, a excepció de «Preferència en l'accés als cursos de formació del PAS», referida a la prioritat en l'accés als cursos de formació per part del pas que s'incorpore al seu lloc laboral després de gaudir del permís per maternitat/paternitat o una excedència per atenció a fills o filles o familiars dependents, una dada que posa de manifest que si bé la normativa en termes generals no és coneguda per aquest collectiu, la seua concreció en mesures fa augmentar el coneixement del marc legal. No obstant això, cal destacar les diferències entre dones i homes, ja que són elles les que estan més familiaritzades amb les mesures, atès que, a excepció de la «Preferència en accés als cursos de formació del PAS», les dones les coneixen per damunt del $52 \%$. Els homes només superen aquest percentatge en set de les tretze mesures, resultats que corroboren els diversos estudis que qualifiquen la conciliació com una qüestió femenina.

Les mesures que més es coneixen són les relacionades amb les criatures $\mathrm{i}$ les visites mèdiques $\mathrm{i}$ intervencions quirúrgiques, totes per damunt del $60 \%$, encara que des d'un punt de vista de gènere, les dones les coneixen en una proporció més gran. El grau de coneixe- 
ment disminueix, sobretot en els homes, en els casos d'adaptacions/ reduccions per a cuidar persones en situació de dependència-grans o amb discapacitat. La mesura menys coneguda (a excepció de la mesura «Preferència en l'accés als cursos de formació»)) pels homes és la «Flexibilitat horària en la jornada de treball per raó de guarda legal de menors o familiars que requerisquen dedicació especial» $(41,9 \%)$, seguida de l' «Adaptació/reducció de la jornada per raó d'atenció directa a familiars que per edat, accident o malaltia no puga valdre's per si mateix» $\mathrm{i}$ «Reducció/permís/excedència per violència de gènere». En el cas de les dones és (a excepció de la mesura «Preferència en l'accés als cursos de formació») «Adaptació/reducció de la jornada de treball per raó de malaltia llarga o crònica que impedisca realitzar la jornada laboral completa» (52,7 \%), seguida d' «Adaptació/reducció de la jornada per raó d'atenció directa a familiars que per edat, accident o malaltia no puga valdre's per si mateix», encara que totes per damunt del $50 \%$.

Hem d'assenyalar, que la mesura menys coneguda, tant pels homes com per les dones, és la «Preferència en l'accés als cursos de formació del PAS» que només la coneixen el 24,7 \% dels homes enquestats i el 20,7 \% de les dones.

De l'anàlisi també s'extrau que les mesures amb major antiguitat i difusió social i mediàtica són les més conegudes: «Permís per intervenció quirúrgica de familiars o malaltia greu familiar» $(87,9 \%)$; «Permís de maternitat/paternitat o permís d'adopció i acolliment» $(83,9 \%)$ i «Permís de lactància o acumulació d'hores de lactància» $(81 \%)$, encara que novament són elles les que més assenyalen tenirne coneixement. En el cas del permís de lactància són 19 punts de diferència a favor de les dones, $\mathrm{i}$ en el permís de maternitat/paternitat 16 punts.

De la resta de mesures destaca la diferència percentual, des d'una perspectiva de gènere, respecte al coneixement de les mesures «Excedència per atenció de menors o familiars a càrrec seu» (23 punts); «Adaptació/reducció de jornada per atenció de menors fins a 12 anys» 
$\mathrm{i}$ «Flexibilitat horària en la jornada laboral per guarda legal de menors o familiars que requerisquen dedicació especial» (ambdues 19 punts). Xifres que confirmen que per a les dones l'ocupació no és el valor essencial per a les seues vides com ho són altres com el familiar. ${ }^{71}$

També es mostra una diferència de 23 punts en la mesura «Reducció/permís o excedència per violència de gènere» $(67,3 \%$ i $44,1 \%$, respectivament).

Per tant, podem afirmar que el grau de coneixement de les distintes mesures és desigual, encara que la xifra global de cada una d'elles és més elevada que el coneixement de la legislació en matèria d'igualtat, tant en homes com en dones.

En relació amb l'ús de cada una de les mesures de conciliació, cal assenyalar que cap persona ha sol·licitat «Adaptació/reducció de la jornada de treball per raó d'atenció de fill/a menor afectada per càncer o una altra malaltia greu», ni «Reducció/permís/ excedència per raó de violència de gènere».

Quant a la resta, les més utilitzades són «Permís per intervenció quirúrgica de familiars o malaltia greu familiar» $\mathrm{i}$ «Permís de maternitat/paternitat o permís d'adopció o acolliment», ambdues usades en major grau per les dones. Si ens detenim en el permís de maternitat/paternitat, la diferència percentual entre homes i dones és de 19 punts.

La tercera mesura quant a ús és el «Permís per a visites mèdiques $\mathrm{i}$ assistència a persones menors, ancianes $\mathrm{i}$ amb discapacitat», utilitzada en una major proporció per dones $(34,4 \%$ dels homes enfront del 57,3\% de les dones). Així mateix, seria interessant desagregar per sexes si les visites que realitzen són per a menors, persones ancianes o amb discapacitat, per a conèixer si són les dones les que s'ocupen de les persones ancianes o amb discapacitat, a més de les menors, tal

71. Segons dades de l'Institut de la Dona, el 2012, 29.651 persones van reduir el seu horari laboral per a cuidar un fill o filla menor, de les quals el 94,98 \% eren dones, i 6122 persones van estar en excedència a temps complet per a atendre els seus familiars, el 85,67 \% de les quals eren dones. 
com mostren les tendències anteriorment assenyalades amb les excedències per cures de familiars.

La quarta de les mesures que més s'ha utilitzat és el «Permís de lactància o acumulació d'hores de lactància» (35\%), encara que desagregant per sexe s'observa una gran diferència quant a l'ús realitzat pels homes i per les dones. Només un 9,7\% d'ells assenyalen que han sol·licitat el permís de lactància. No obstant això, si realitzem una comparativa de l'ús que del permís de lactància realitzen els homes a Espanya, el percentatge dels homes PAs de l'UJI és superior a la mitjana espanyola, que no arriba ni a un $2 \%(99,5 \%$ de dones respecte al $0,5 \%$ del temps que utilitzen els pares o un altre progenitor). ${ }^{72}$

La mesura «Adaptació/reducció de la jornada de treball per raó d'atenció a menors fins a 12 anys» i la mesura «Excedència per atenció a criatures o familiars a càrrec seu» són usades globalment en un percentatge semblant (16,1\% i $14,1 \%$ respectivament), no obstant això si desagreguem per sexe, novament s'observen grans diferències, són elles les que adapten o redueixen la seua jornada per a 1'atenció a menors de fins a 12 anys $(24 \%$ de dones enfront del 4,3\% dels homes), fins i tot sent coneguda per ambdós, i els que sol·liciten excedències per atenció a criatures o familiars a càrrec seu, només un 2,2\% d'homes 1'han utilitzada ( $22 \%$ de dones enfront del $2,2 \%$ dels homes). Aquestes dades corroboren que continuen sent les dones les que s'adapten o redueixen les jornades laborals per a l'atenció de persones en situació de dependència encara que, en el cas del PAs de la Universitat Jaume I, se sol·liciten més adaptacions/reduccions per criatures que per persones amb discapacitat o per familiars de fins a segon grau que per raó d'edat, accident o malaltia, no puguen valdre's per si mateixes i no exercisquen activitat retribuïda. Això es pot deure al fet que les persones enquestades només indiquen en un 11,3 $\%$ que tenen persones en situació de dependència a càrrec seu, no

72. http://www.cime2011.org/home/panel1/cime2011_P1_PPiiNA.pdf [Font consultada al novembre de 2013]. 
obstant això, seria interessant desagregar si les excedències són per a l'atenció a menors o altres persones familiars a càrrec seu.

En aquest assumpte cal indicar les repercussions que ambdues mesures tenen en la vida professional de qui les empra: disminució o supressió en termes salarials, amb les conseqüències posteriors per a la jubilació, a més de les possibilitats de realitzar mèrits que afavorisquen la carrera professional. I com hem apuntat, en el cas del PAs de 1'UJI, són les dones les que les han usades en una major proporció (20 punts de diferència respecte als homes en ambdues mesures).

Les mesures que a penes han sigut utilitzades, tant per homes com per dones, i a més sense a penes diferència percentual, han sigut «Adaptació/reducció de la jornada de treball per raó de convivència amb l'atenció directa a una persona amb discapacitat física, psíquica o sensorial» ( $1,1 \%$ homes i $2 \%$ dones), «Adaptació/reducció de la jornada de treball per raó d'atenció directa a familiars que per edat, accident o malaltia no poden valdre's per si mateix» $(1,1 \%$ homes $i$ $2,7 \%$ dones) i «Flexibilitat horària en la jornada de treball per raó de guarda legal de menors o familiars que requerisquen dedicació especial» (4,3\% homes i $6 \%$ dones).

Respecte a aquesta última mesura és possible que l'ús mínim puga deure's al fet que la Universitat Jaume I té una bona política de flexibilitat horària d'entrada, amb l'autorització prèvia de la unitat administrativa on es presta el servei, de 7.30 a $9.00 \mathrm{~h}$ per a les jornades de matí (amb obligatorietat de romandre en el lloc de treball de 9.00 a $14.00 \mathrm{~h}$ ), i de 14.00 a $15.00 \mathrm{~h}$ en les jornades de vesprada (en aquest cas, 1'obligatorietat és de 15.00 a $20.00 \mathrm{~h}$ ). La resta es podrà completar entre les $7.30 \mathrm{i}$ les $9.00 \mathrm{~h}$ i les $14.00-21.00 \mathrm{~h}$ (per al torn de matí) i, entre les 8.00 i les $15.00 \mathrm{~h}$ i les $20.00-22.00 \mathrm{~h}$ (per a torn de vesprada). Si es té jornada de matí, s'ha de treballar com a mínim una vesprada setmanal (de 15.30 a 17.30 h) i en el cas de jornada vespertina s'haurà de tenir presència com a mínim un matí (de 12.30 a $14.30 \mathrm{~h})$. 
A més, es pot afegir una hora diària en la part fixa, dues en el cas de famílies monoparentals, si es tenen a càrrec persones majors de 65 anys que requerisquen atenció especial, criatures o menors en acolliment de fins a 12 anys, familiars amb malaltia greu o discapacitat igual o superior al $65 \%$, fins a segon grau de consanguinitat. També es disposen de dues hores de la part fixa si es tenen criatures amb discapacitat. En relació a les altres dues pot ser fruit que les persones enquestades només indiquen en un $11,3 \%$ que tenen persones en situació de dependència a càrrec seu.

Cal destacar que la mesura «Reducció de la jornada de treball per raó de malaltia llarga o crònica que impedisca realitzar la jornada laboral completa» només ha sigut utilitzada per dos homes del PAS enquestat.

Per tant, podem considerar que l'ús que el col·lectiu PAS realitza de les mesures de conciliació és baix, només tres mesures estan per damunt del $48 \%$, la resta per davall del $16 \%$, i també ací són les relacionades amb els menors les que més s'utilitzen. A més, podem afirmar que aquelles mesures que suposen una utilització puntual i que no tenen efectes en les condicions laborals com ara els permisos per intervenció quirúrgica o visites mèdiques, són utilitzades indistintament per homes i dones, mentre que aquelles que poden suposar una repercussió en la carrera professional (excedències o reduccions de jornades) són utilitzades per dones, corroborant novament que si bé les mesures són presentades igualment per homes i dones, continuen sent elles les que assumeixen les responsabilitats de les cures. Així mateix, les mesures que més s'utilitzen són aquelles que més es coneixen. 
De manera gràfica:

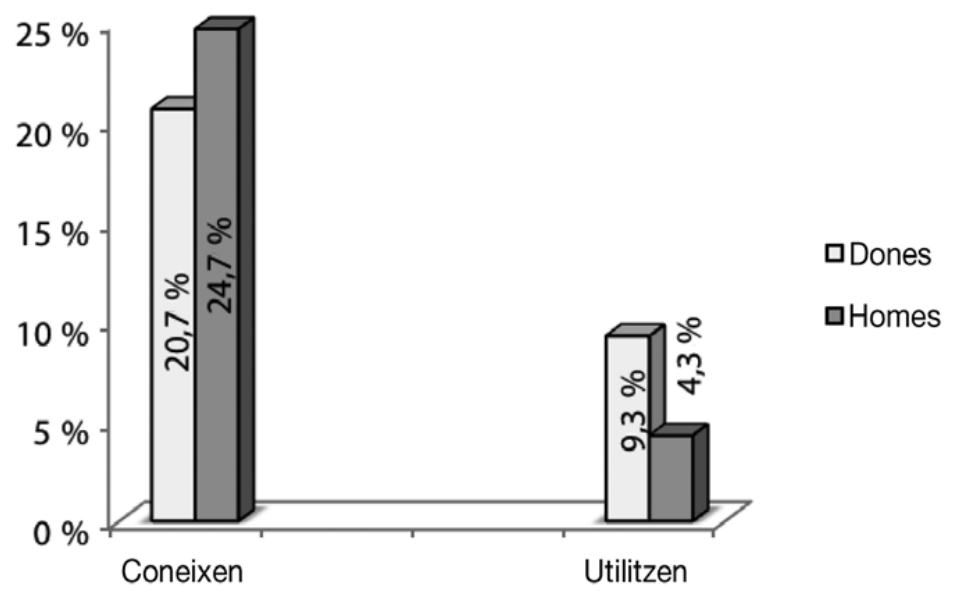

Gràfic 3.

Coneixement $\mathrm{i}$ ús de la mesura «Preferència en l'accés als cursos de formació del PAS»

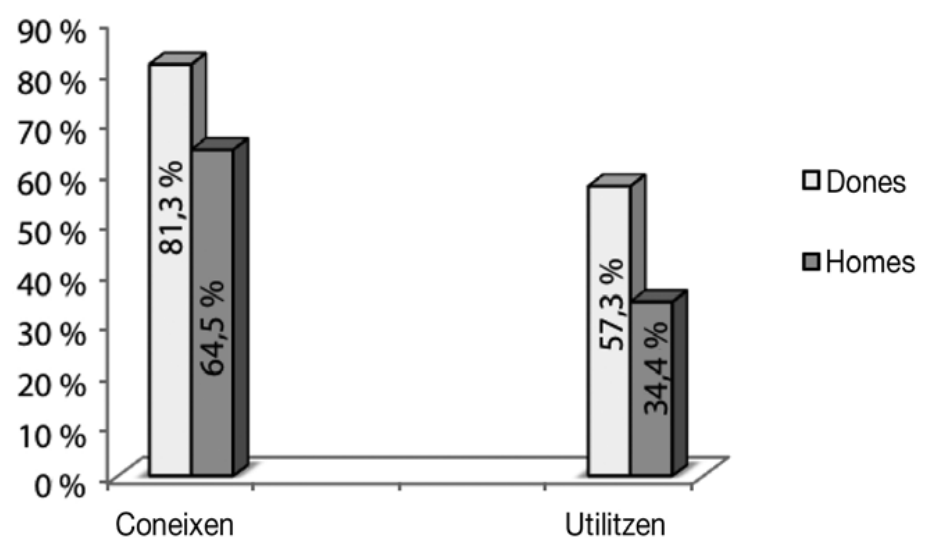

Gràfic 4.

Coneixement $\mathrm{i}$ ús de la mesura «Permís per a visites mèdiques $\mathrm{i}$ assistència a persones menors, ancianes i amb discapacitat del PAS» 


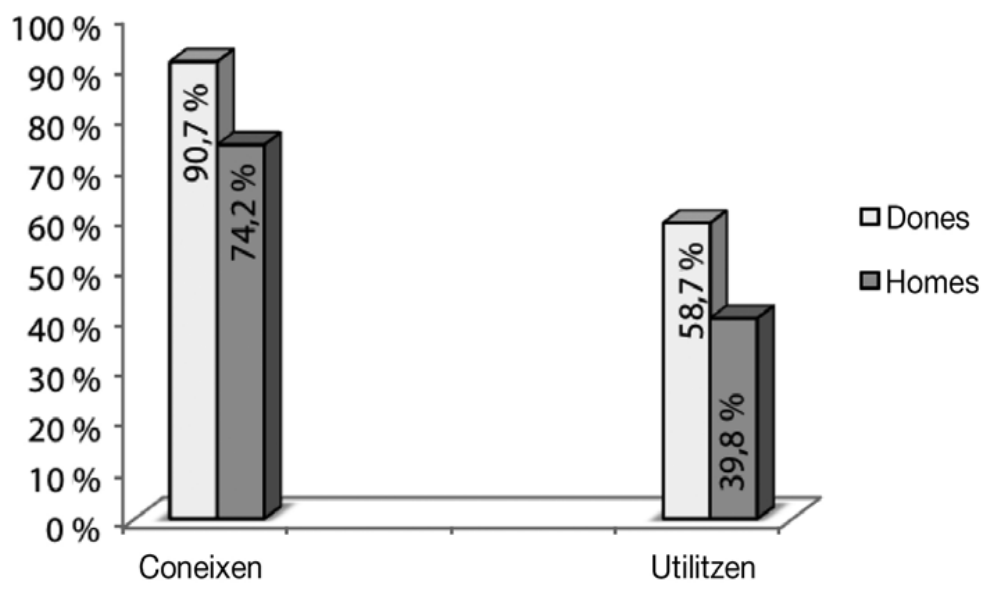

Gràfic 5.

Coneixement i ús de la mesura «Permís maternitat/paternitat o permís d'adopció o acolliment»

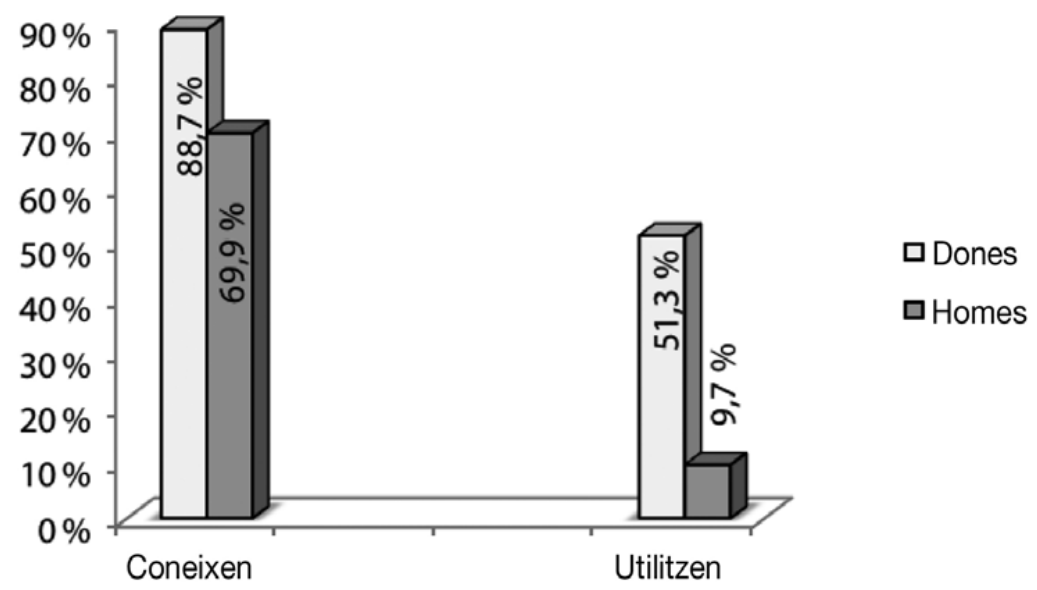

Gràfic 6.

Coneixement i ús de la mesura «Permís de lactància o acumulació d'hores del PAS» 


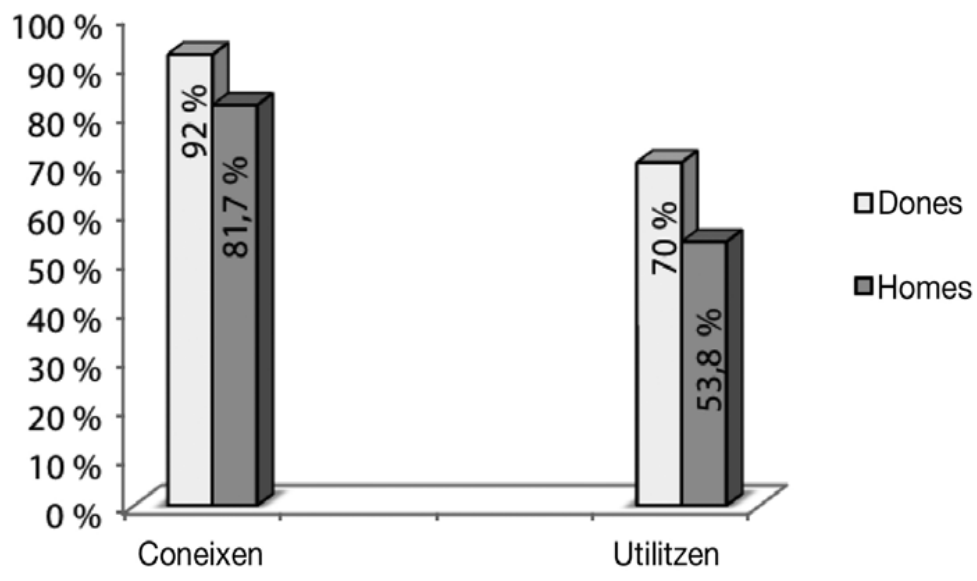

Gràfic 7.

Coneixement i ús de la mesura «Permís per intervenció quirúrgica de familiars o malaltia greu de familiar del PAS»

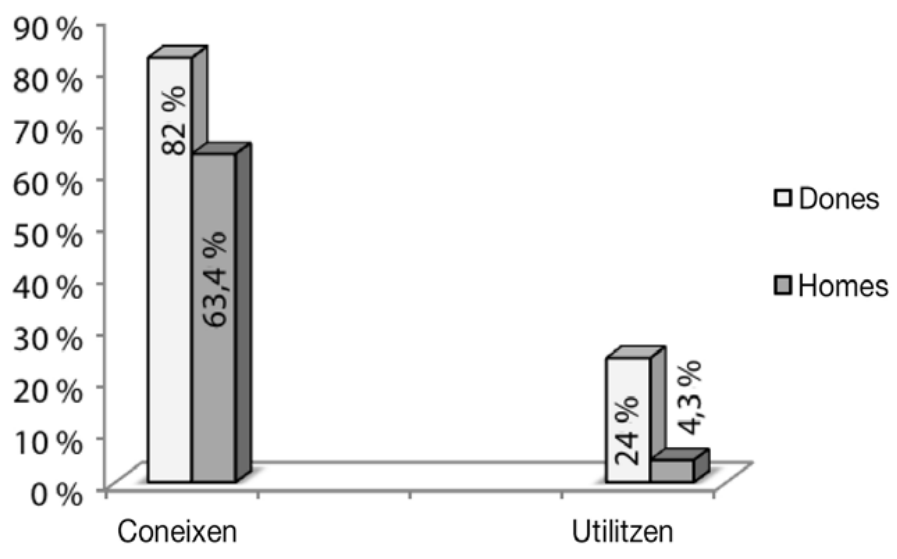

Gràfic 8 .

Coneixement i ús de la mesura «Permís maternitat/paternitat o permís d'adopció o acolliment» 


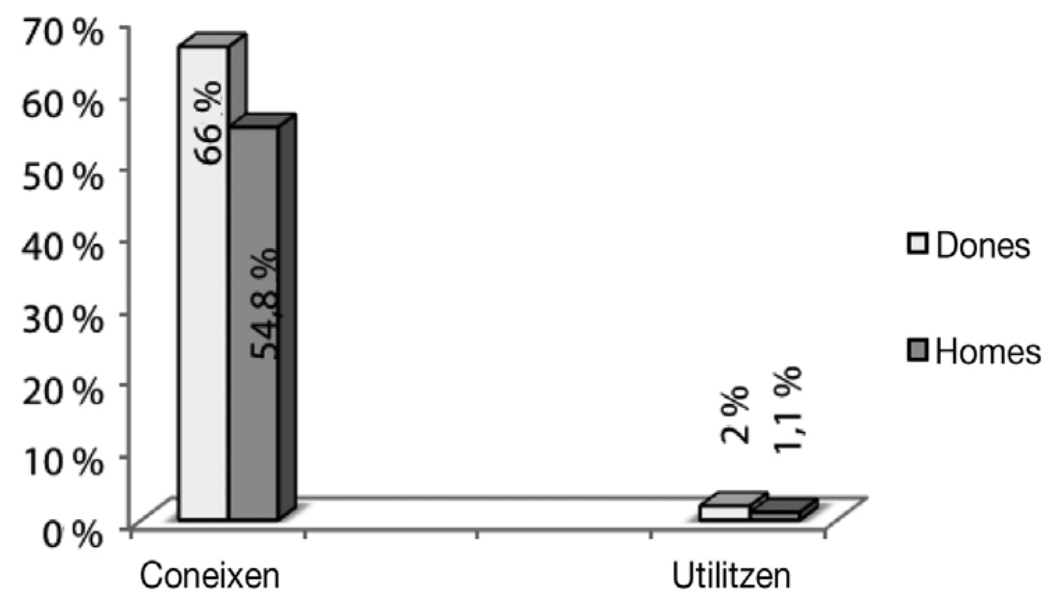

Gràfic 9.

Coneixement i ús de la mesura «Adaptació/reducció de la jornada de treball per atenció directa a una persona amb discapacitat»

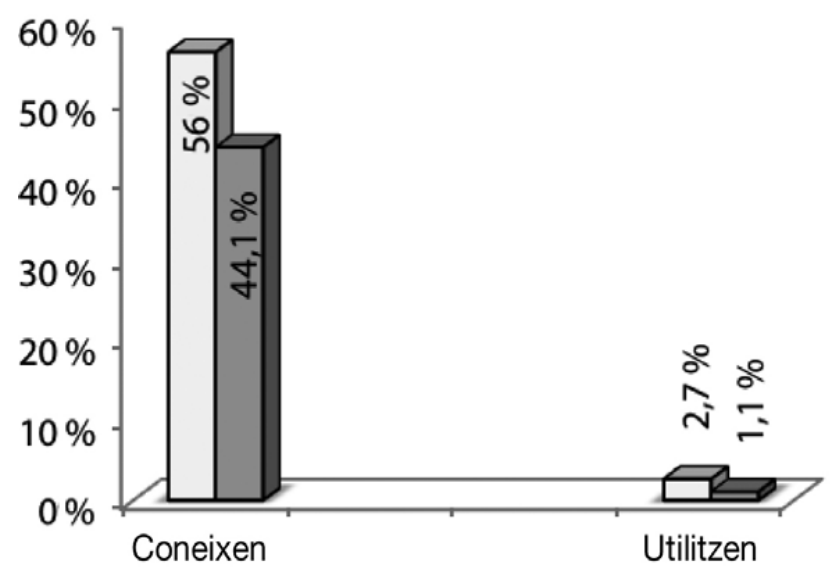

口Dones

ㅁomes

Gràfic 10.

Coneixement i ús de la mesura «Adaptació/ reducció de la jornada de treball per atenció a familiars de fins al segon grau del PAS» 


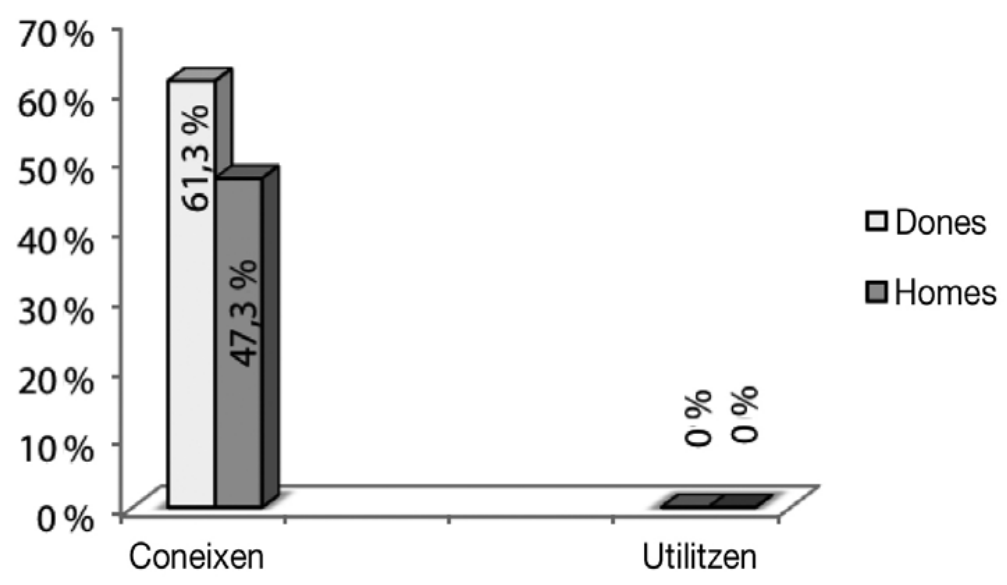

Gràfic 11.

Coneixement i ús de la mesura «Adaptació/reducció de la jornada de treball per raó d'atenció a filla o fill menor afectada per càncer o una altra malaltia greu del PAS»

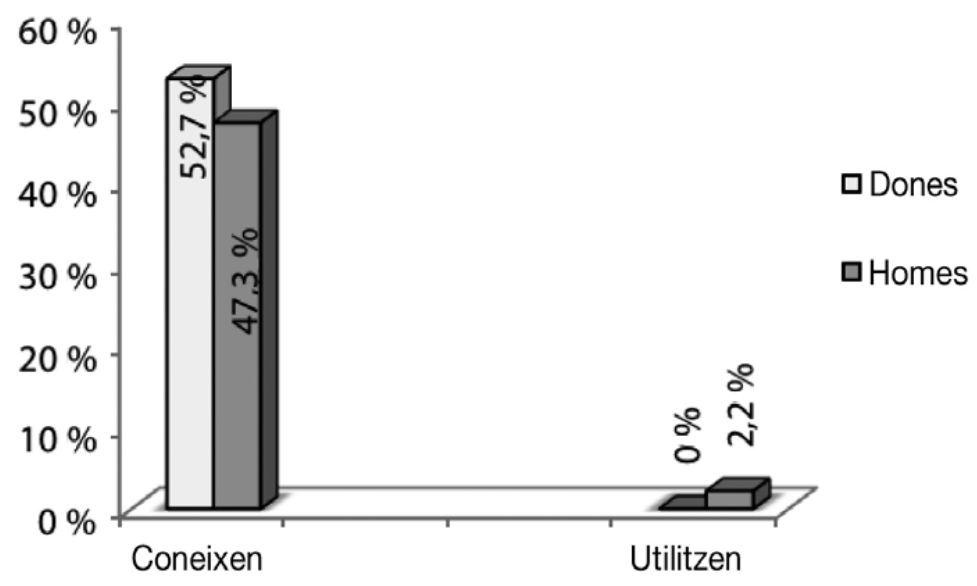

Gràfic 12.

Coneixement i ús de la mesura «Adaptació/reducció de la jornada de treball per raó de malaltia llarga o crònica del PAS» 


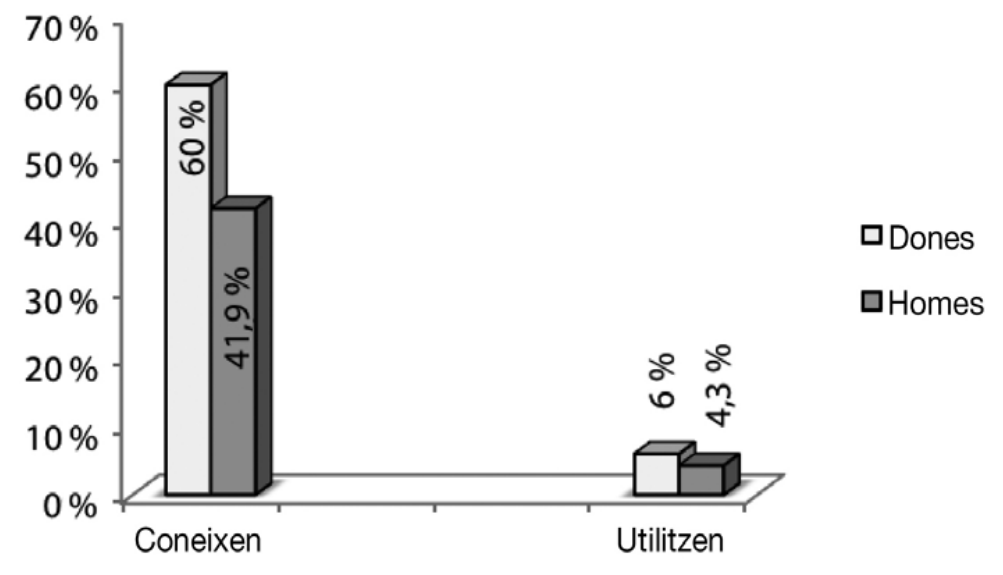

Gràfic 13.

Coneixement $\mathrm{i}$ ús de la mesura «Flexibilitat horària en la jornada de treball per raó de guarda legal de menors o familiars que requerisquen dedicació especial PAS»

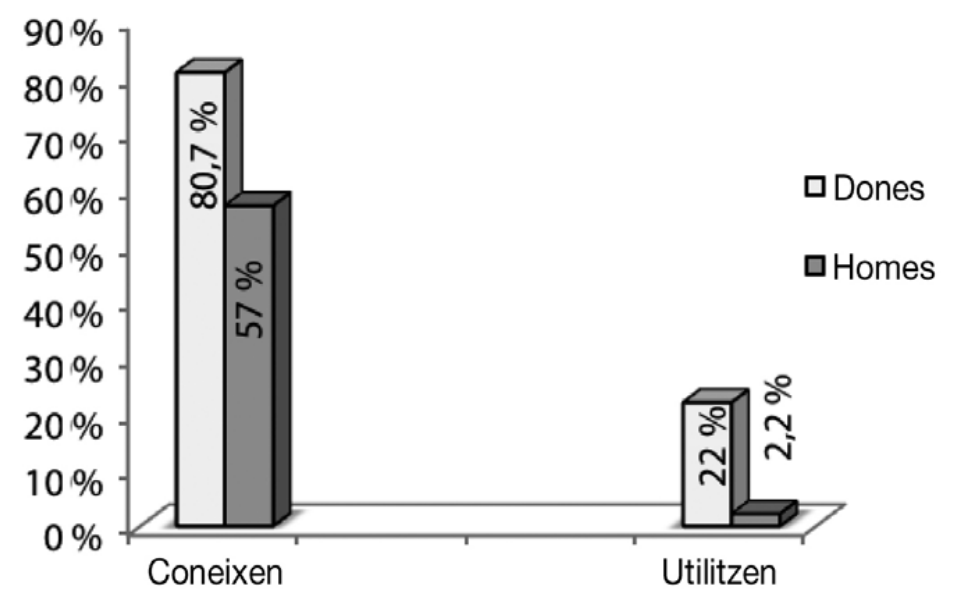

Gràfic 14.

Coneixement i ús de la mesura «Excedència per atenció a criatures o familiars a càrrec seu del PAS» 


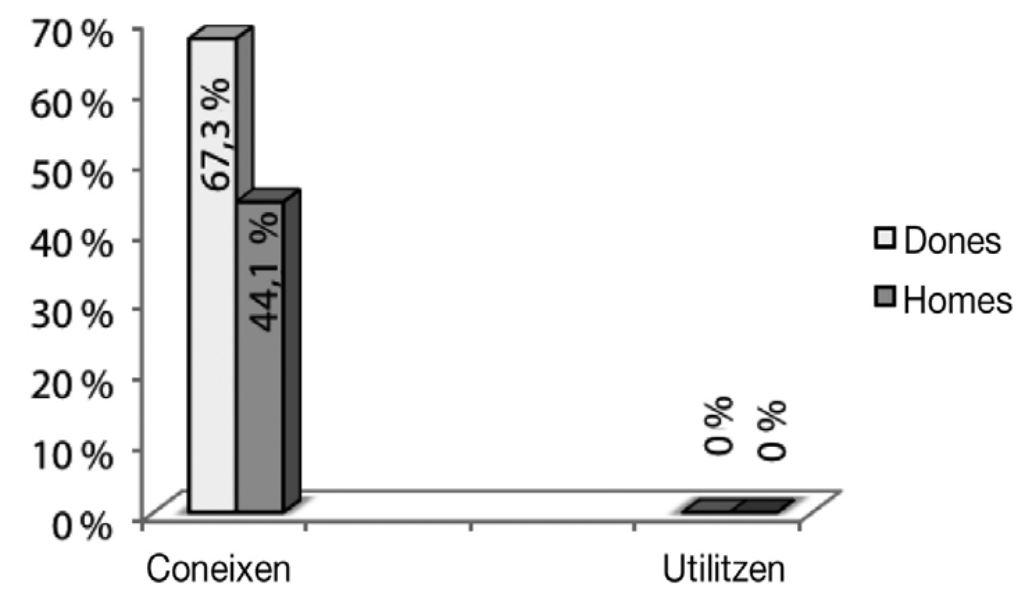

Gràfic 15.

Coneixement i ús de la mesura «Reducció/ permís/ excedència per raó de violència de gènere del PAS»

\subsection{EL PERSONAL DOCENT I INVESTIGADOR (PDI)}

\subsubsection{Coneixement de la normativa i del I Pla d'Igualtat}

Els resultats reflecteixen, en termes generals, un elevat grau de desconeixement de la legislació vigent en matèria de conciliació; tan sols el $26 \%$ de les persones enquestades del PDI diu conèixer la normativa legal. Si realitzem l'anàlisi desagregant per sexe, les dones coneixen més la normativa legal en matèria de conciliació que els homes (36\% de les dones enfront del $17 \%$ dels homes), aspecte que també es manté, com es veurà més endavant, en el coneixement de les mesures concretes en matèria de conciliació. 
Taula 3.

PDI que coneix la legislació en matèria de conciliació

\begin{tabular}{cccc} 
Resposta & Total & Dones & Homes \\
\hline Sí & $26 \%$ & $36 \%$ & $17 \%$ \\
No & $69 \%$ & $59 \%$ & $78 \%$ \\
\hline
\end{tabular}

Quant a la normativa específica de l'UJi, recollida en el I Pla d'Igualtat, les xifres milloren, ja que afirma conèixer-la quasi el $32 \%$ de la plantilla enquestada, encara que el desconeixement continua sent àmpliament majoritari. La millora respon a l'increment del percentatge d'homes que afirma conèixer el I Pla d'Igualtat, que ascendeix al $28 \%$, mentre que en les dones roman invariable. Tal com s'ha apreciat en el PAs, també en aquesta ocasió el grau de coneixement és uniforme en les dues qüestions en el grup de les dones (36\% coneixen tant la normativa general com el I Pla d'Igualtat), mentre que en els homes s'incrementa el coneixement sobre el I Pla d'Igualtat (28\% i $17 \%$, respectivament), probablement perquè és una normativa més pròxima i que recull les mesures concretes per al seu entorn laboral.

Taula 4.

PDI que coneix el I Pla d'Igualtat de l'UJI

\begin{tabular}{cccc} 
Resposta & Total & Dones & Homes \\
Sí & $32 \%$ & $36 \%$ & $28 \%$ \\
No & $64 \%$ & $58 \%$ & $68 \%$ \\
\hline
\end{tabular}


El resultat evidencia que la majoria d'aquest col-lectiu -i, en particular, els homes- no coneix el principal instrument de l'us per a facilitar la conciliació de la vida personal, familiar i professional.

Pot afirmar-se, en conseqüència, que la majoria de persones enquestades del PDI de l'UJI desconeix tant la legislació en matèria de conciliació en termes generals, com el I Pla d'Igualtat de la Universitat particularment.

\subsubsection{Coneixement i ús de les distintes mesures de conciliació per part del $P D I$}

A continuació s'analitzen les dades sobre coneixement de les distintes mesures. Com es podia esperar, les més conegudes són aquelles que estan recollides en la legislació i tenen més entitat, antiguitat i difusió social i mediàtica. En concret, destaquen els «Permisos de maternitat-paternitat», que són coneguts pel $77 \%$, seguits pel «Permís de lactància», amb un 72,6\%.

De la resta de mesures previstes en l'enquesta (un total de tretze), tan sols és majoritàriament coneguda, pel total de persones del PDI enquestades, la que es refereix al «Permís per intervenció quirúrgica de familiars o malaltia familiar greu». Totes les altres mesures són conegudes per menys de la meitat del collectiu, i en cinc casos les xifres se situen per davall del $25 \%$.

Les diferències entre dones i homes són notables i significatives des del punt de vista d'una anàlisi amb perspectiva de gènere. Les dones estan més familiaritzades amb totes les mesures que els homes, corroborant l'afirmació, assenyalada per nombrosos estudis, que la conciliació continua sent, tant des del punt de vista de la mentalitat social i personal com des del de la pràctica, un assumpte preferentment femení.

En la taula següent es presenten les distintes mesures ordenades, de major a menor valor obtingut, segons el grau de coneixement que 
tenen de cada una d'aquestes les persones enquestades. S'inclouen, amb fins comparatius, els resultats desglossats per sexe.

\section{Taula 5.}

PDI que coneix cada una de les distintes mesures de conciliació, per sexe. Percentatge sobre el col·lectiu de referència

\section{Mesura coneguda}

Permís de maternitat/paternitat o

permís d'adopció o acolliment

Permís de lactància o acumulació

d'hores de lactància

Permís per intervenció quirúrgica de familiars o malaltia greu familiar

Excedència per atenció a menors 0 familiars a càrrec seu

Preferència en l'elecció d'horaris lectius

Adaptació/reducció de jornada per atenció a menors de fins a 12 anys

Permís per a visites mèdiques $i$

assistència a persones menors, ancianes i amb discapacitat

Reducció de la jornada per malaltia llarga o crònica que impedisca la realització de la jornada completa Adaptació/reducció de jornada per convivència amb l'atenció directa $a$ una persona amb discapacitat

\section{Total Dones Homes}

$77 \% \quad 85,5 \% \quad 72,3 \%$

$72,6 \% \quad 81,2 \% \quad 65 \%$

$51,3 \% \quad 56,5 \% \quad 46,6 \%$

$45 \% \quad 53,9 \% \quad 37,4 \%$

$39,6 \% \quad 42,9 \% \quad 36,8 \%$

$36,3 \% \quad 42,9 \% \quad 30,1 \%$

$32,7 \% \quad 33,1 \% \quad 32,5 \%$

$25,8 \% \quad 28,6 \% \quad 23,3 \%$

$24,5 \% \quad 26,6 \% \quad 22,7 \%$ 


\section{Mesura coneguda}

Flexibilitat horària en la jornada laboral per guarda legal de menors o familiars que requerisquen dedicació especial

Adaptació/reducció de jornada per atenció a fill/a menor amb malaltia greu que implique hospitalització de llarga duració

Adaptació/reducció de jornada per atenció directa a familiar fins a segon grau, que per edat, accident o malaltia no puga valdre's per si mateix i no exercisca activitat retribuïda

Reducció/permís/excedència per violència de gènere

\section{Total Dones Homes}

$23,9 \% \quad 25,3 \% \quad 22,7 \%$

$21,1 \% \quad 22,1 \% \quad 20,2 \%$

$18,2 \% \quad 17,5 \% \quad 19 \%$

Tal com s'acaba d'assenyalar, la mesura més coneguda per ambdós sexes és la del «Permís de maternitat/paternitat». Ara bé, en el cas de les dones el percentatge ascendeix a més del $85 \%$, mentre que en el dels homes, se situa en el 72,3\%.

La diferència és encara més elevada en la mesura corresponent als «Permisos de lactància», on s'observa un avantatge de més de 16 punts a favor de les dones. Encara així, és una mesura coneguda per la majoria dels homes, el $65 \%$.

Les xifres descendeixen notablement en la tercera mesura, el «Permís per intervenció quirúrgica de familiars o malaltia greu familiar». És coneguda pel $56,5 \%$ de les dones, però per menys de la meitat dels homes, en concret, pel 46,6\%.

La següent, en grau de coneixement, és l'«Excedència per atenció a menors o familiars a càrrec seu». Encara són majoria les dones a qui els resulta familiar, quasi el $54 \%$, però en els homes el percentatge 
descendeix al 37,4\%. Previsiblement, la possibilitat de gaudir d'una excedència per motius familiars per a dedicar-se a les tasques d'atenció és un poc més pròxim materialment i simbòlicament a l'entorn femení i això podria estar en la base d'aquesta diferència. Això es traduiria en el fet que a pesar que la difusió de la informació en l'entorn social i institucional es realitze sense distinció, es tracta d'una mesura que consisteix a facilitar la realització d'una tasca fortament marcada pel gènere, de manera que troba més receptivitat en les dones.

$\mathrm{La}$ «Preferència en l'elecció d'horaris lectius» és una mesura definida en el I Pla d'Igualtat de l'us. És coneguda per un nombre més elevat de persones, el 39,6\%, de les que diuen conèixer aquest pla en el seu conjunt, el $32 \%$. El motiu podria trobar-se en el fet que afecta de manera central les condicions laborals del PDI i que ha sigut comunicada de manera específica als departaments perquè la tinguen en compte a l'hora d'elaborar els plans d'ordenació docent. Encara així, de nou són les dones les que addueixen un coneixement més alt d'aquesta, sis punts més en comparació amb els homes. Ens trobem, una vegada més, amb el fet que la tasca que pretén facilitar l'atenció familiar quotidiana s'ubica, encara que potser cada vegada menys, en territori femení.

Aquesta línia d'anàlisi podria quedar reforçada si considerem la mesura següent, «Adaptació/reducció de jornada per atenció a menors de fins a 12 anys». Aquesta mesura al·ludeix també a la cura dels menors, però implica no tant una millora com una disminució de la jornada laboral, amb la qual cosa comporta en termes salarials i de possibilitats de realitzar mèrits que afavorisquen la carrera professional. En aquest cas, la diferència entre dones i homes és més elevada que en l'anterior, i suposa quasi 13 punts.

$\mathrm{El}$ «Permís per a visites mèdiques i assistència a persones menors, ancianes i amb discapacitat» és una de les mesures en què el grau de coneixement presenta menys diferències entre dones, el 33,1\%, i homes, el 32,5\%. Es tracta d'una mesura d'aplicació puntual, que no reporta, en principi, una minva en les condicions i oportunitats 
laborals. Encara així, resulta notable que tan sols una de cada tres persones del PDI afirme conèixer-la.

La «Reducció de la jornada per malaltia llarga o crònica» que impedisca la realització de la jornada completa és una mesura coneguda pel 25,8 \% del personal PDI. De nou, són les dones les que addueixen més coneixement d'aquesta, el 28,6\%, en comparació amb els homes, el $23,3 \%$.

Tal com pot observar-se en la taula 5, les cinc mesures restants són conegudes, en termes globals, per menys de la quarta part del PDI. Amb l'única excepció de la referida a la «Reducció/permís/excedència per violència de gènere», són més conegudes per les dones que pels homes.

L'anàlisi dels resultats obtinguts permet afirmar que el grau de coneixement de les distintes mesures és molt desigual, la qual cosa explica que la xifra global de coneixement de la legislació en matèria de conciliació siga, entre el personal docent $\mathrm{i}$ investigador tan sols del $26 \%$. En concret, hi ha set mesures de conciliació que es coneixen per damunt de la mitjana general de coneixement de la legislació en matèria de conciliació. En tres casos es duplica, almenys, la mitjana general en matèria de conciliació: «Permís de maternitat/paternitat», «Permís de lactància/acumulació d’hores» i «Permís per intervenció quirúrgica/malaltia greu familiar».

En altres quatre casos el grau de coneixement se situa per damunt de la mitjana, però sense arribar a duplicar-la: «Excedència per atenció a filles o fills o familiars», «Preferència en l'elecció d'horaris lectius», «Adaptació/reducció de jornada per atenció a filles o fills menors de fins a 12 anys» $i$ «Permís per a visites mèdiques $i$ assistència $a$ persones menors, ancianes i amb discapacitat». En la resta, el grau de coneixement se situa per davall de la mitjana general expressada en matèria de conciliació. Dit en altres paraules, les persones enquestades saben, en la majoria dels casos, que hi ha més mesures de les que coneixen amb un cert detall, per això no responen afirmativament a la pregunta global sobre el coneixement de la legislació. 
D'altra banda, resulta interessant assenyalar que les mesures menys conegudes són aquelles que impliquen adaptació o disminució de la jornada laboral. En el cas del PDI ens trobem que la reducció de la dedicació comporta una minva considerable de les condicions laborals i de carrera, la qual cosa, unida a la relativa flexibilitat en la distribució horària i temporal de part de les seues tasques, pot afavorir un cert desinterès per aquest tipus de mesures.

En la taula que es presenta a continuació es mostren les dades d'utilització de les distintes mesures de conciliació per part del PDI. S'hi han reflectit tan sols nou de les tretze mesures analitzades, ja que les quatre restants no han sigut utilitzades en cap cas.

Taula 6.

PDI que utilitza/ha utilitzat cada una de les distintes mesures de conciliació, per sexe. Percentatge sobre el col·lectiu de referència

$\begin{array}{lccc}\text { Mesura utilitzada } & \text { Total } & \text { Dones } & \text { Homes } \\ \begin{array}{l}\text { Permís de maternitat/paternitat o } \\ \text { permís d'adopció o acolliment }\end{array} & 34,4 \% & 51,3 \% & 18,4 \% \\ \begin{array}{l}\text { Permís de lactància o acumulació } \\ \text { d'hores de lactància }\end{array} & 18,6 \% & 34,4 \% & 3,7 \% \\ \begin{array}{l}\text { Permís per intervenció quirúrgica de } \\ \text { familiars o malaltia greu familiar }\end{array} & 8,8 \% & 13,0 \% & 4,9 \% \\ \begin{array}{l}\text { Excedència per atenció a menors o } \\ \text { familiars a càrrec seu }\end{array} & 1,6 \% & 2,6 \% & 0,6 \% \\ \begin{array}{l}\text { Preferència en l'elecció d'horaris } \\ \text { lectius }\end{array} & 6,0 \% & 7,1 \% & 4,9 \% \\ \begin{array}{l}\text { Adaptació/reducció de jornada per } \\ \text { atenció a menors de fins a 12 anys }\end{array} & 1,3 \% & 1,9 \% & 0,6 \%\end{array}$


Mesura utilitzada

Permís per a visites mèdiques $\mathrm{i}$

assistència a persones menors, ancianes i amb discapacitat

Reducció de la jornada per malaltia llarga o crònica que impedisca la realització de la jornada completa

Reducció/permís/excedència per violència de gènere

\section{Total Dones Homes}

$5,0 \% \quad 7,8 \% \quad 2,5 \%$

$0,9 \% \quad 1,3 \% \quad 0,6 \%$

$0,3 \% \quad 1 \% \quad 0,6 \%$

La mesura més utilitzada per ambdós sexes és el «Permís de maternitat/paternitat per naixement, adopció o acolliment», seguida del «Permís de lactància o acumulació de les hores de lactància». Si els resultats en aquestes dues mesures es contemplen desagregats per sexe, s'observa que l'ús d'aquestes mesures de conciliació és predominantment femení $(51,3 \%$ i $18,4 \%$, i $34,4 \%$ i $3,7 \%$, respectivament). A l'hora d'analitzar aquests resultats s'ha de tenir en compte, d'una banda, que estan calculats sobre els totals del PDI per sexe, sense considerar si tenen o no filles o fills.

D'altra banda, el «Permís de paternitat» de tretze dies existeix des de març de 2007, sumant-se al de dos dies per naixement que hi havia fins aquella data, de manera que és possible que alguns dels homes que van ser pares abans de 2007 hagen respost negativament. Quant al «Permís de lactància», un dels factors que ha de considerar-se a l'hora d'interpretar les grans diferències per sexe és que es tracta d'un permís que no pot ser sol-licitat de manera simultània per ambdós progenitors. Això pot propiciar que, encara en el cas que no s'estiga utilitzant la lactància materna, siguen més les dones les que ho solliciten que els homes.

La resta de mesures de conciliació compta amb un ús que podríem qualificar com a anecdòtic o excepcional, en la mesura que no assoleix el $10 \%$ de les respostes. Tres d'elles estan pròximes a aquesta 
xifra: «Permís per intervenció quirúrgica de familiars o malaltia greu familiar», «Preferència en l'elecció d'horaris lectius» $\mathrm{i}$ «Permisos per $a$ visites mèdiques $i$ assistència a persones menors, ancianes $i \mathrm{amb}$ discapacitat». També en aquests supòsits, les dones són les que usen més aquestes mesures de conciliació, encara que les diferències són menors en el cas de la «Preferència en l'elecció d'horaris lectius», justament l'única mesura que no comporta necessàriament la realització de tasques, és a dir, que pot gaudir-se només pel fet de tenir filles o fills menors.

Els permisos, tant per intervenció quirúrgica com per visites mèdiques, suposen una utilització puntual i no tenen efectes en les condicions laborals. Ambdues consideracions podrien contribuir a explicar, d'una banda, el baix ús que fa d'aquestes el PDI, ja que, sobretot en el cas de les visites mèdiques, el fet de no realitzar tasques laborals presencials tots els dies de la setmana, pot fer possible l'ajust, en cas de necessitat, sense haver de sol-licitar el permís; d'altra banda, són mesures que presenten una utilització molt més elevada que aquelles que suposen una adaptació o reducció de la jornada laboral.

\subsubsection{Diferències en el coneixement $i$ ús de les mesures de conciliació entre el PDI}

D'entre totes les variables previstes en el qüestionari, les més significatives a l'hora de descriure $i$ analitzar les diferències dins del PDI són, a més del sexe: l'edat, tenir fills menors de 13 anys i tenir familiars dependents a càrrec seu.

L'edat del PDI marca diferències apreciables en el coneixement de les distintes mesures. En termes generals, les persones més joves són les que mostren un menor coneixement de totes les mesures $i$, les de major edat, les que més les coneixen. Les diferències per sexe, dins de cada grup d'edat, reflecteixen un superior coneixement per part de les dones, amb l'excepció, que mereix ser comentada, del grup de PDI 
menor de 33 anys. En aquest grup d'edat, trobem que, efectivament, hi ha més dones que afirmen conèixer el «Permís de maternitat/paternitat», el «Permís de lactància» i l' «Excedència per atenció a menors o familiars a càrrec seu»; el «Permís per intervenció quirúrgica de familiars o malaltia familiar greu» i l'«Adaptació/reducció de jornada per convivència amb l'atenció directa a una persona amb discapacitat» són recursos coneguts en la mateixa mesura pels dos sexes; però en la resta de mesures, els homes superen les dones.

Una mesura que mereix especial atenció és la que es refereix a la preferència en l'elecció d'horaris lectius.

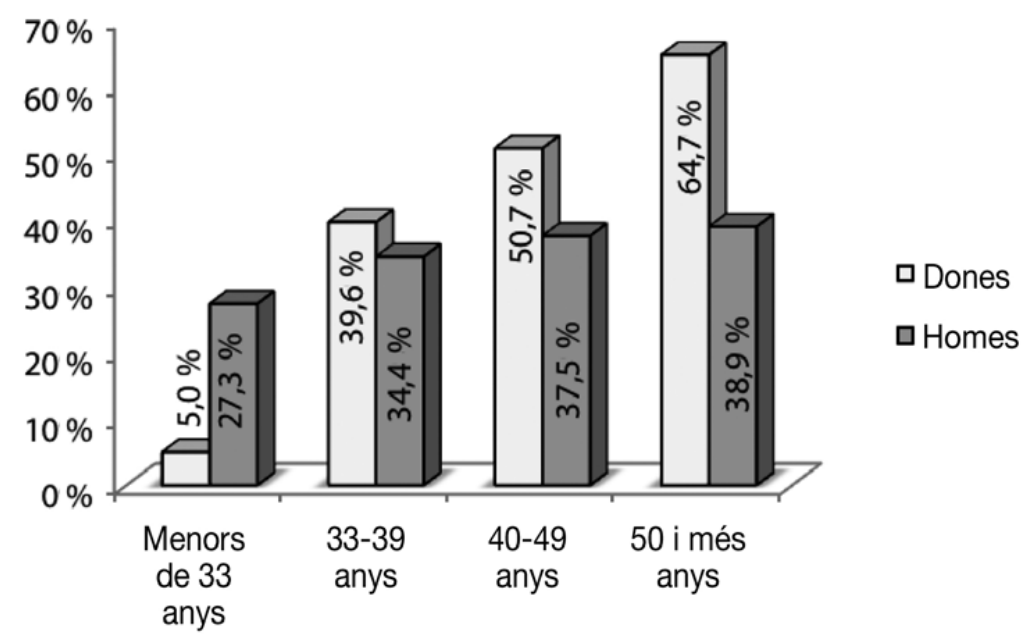

Gràfic 16.

Coneixement de la «Preferència en l'elecció d'horaris lectius», entre el PDI

En el gràfic pot apreciar-se que la mesura és més coneguda com més alta és l'edat del PDI i destaca, de mode notable, el fet que en 
el grup de menor edat el percentatge d'homes que coneix la mesura quintuplica el de les dones.

Quant a l'ús de les distintes mesures per part del PDI, de nou són les persones més joves les que afirmen en menor grau haver-les utilitzat, encara que en aquest cas, precisament l'edat pot haver afavorit no haver-les necessitat de moment.

Altres variables, com ara tenir filles o fills menors de 13 anys $i$ tenir persones dependents a càrrec seu, marquen i expliquen millor les diferències quant a l'ús entre el PDI.

Com es podria esperar, els que tenen a càrrec seu menors de 13 anys presenten un major coneixement i també un major ús d'aquelles mesures més clarament destinades a atendre les necessitats de conciliació derivades de 1'atenció a menors: «Permís de maternitat/paternitat»o «Permís d'adopció o acolliment», «Permís de lactància o acumulació d'hores de lactància», «Excedència per atenció a menors o familiars a càrrec seu», «Preferència en l'elecció d'horaris lectius» $\mathrm{i}$ «Adaptació/ reducció de jornada per atenció a menors de fins a 12 anys».

A pesar que les xifres de coneixement del «Permís de maternitat/ paternitat»o «Permís d'adopció o acolliment» que presenta aquest col·lectiu són elevades, no deixa de sorprendre que persones que han sigut mares o pares en els últims tretze anys diguen desconèixer l'existència d'aquesta mesura, regulada per llei i d'àmplia difusió social i mediàtica. Quant a l'ús, es constata la relativament escassa utilització per part dels homes, ja que tan sols un poc més d'un de cada quatre diu haver-la utilitzat. 


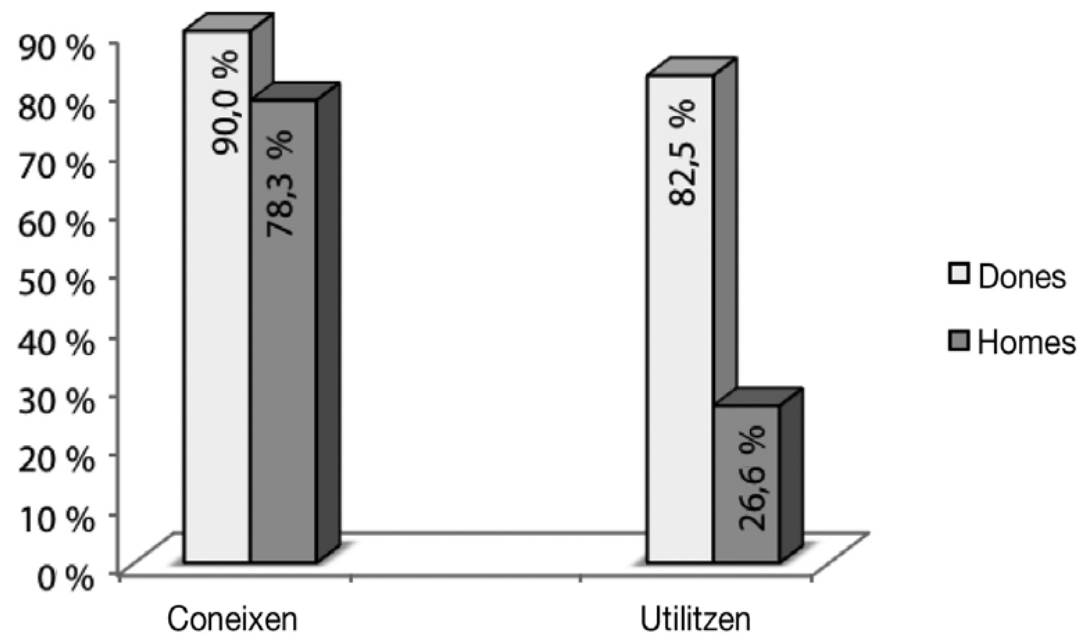

Gràfic 17.

Coneixement i ús del «Permís de maternitat/paternitat»o «Permís d'adopció o acolliment» entre el PDI amb filles o fills menors de 13 anys

Tal com es comentava en presentar les dades generals, el «Permís de lactància» és notablement més conegut per les dones que pels homes, però convé destacar que això ocorre fins i tot en els casos de les persones amb filles o fills menors. La mesura és o ha sigut utilitzada per la majoria de les dones i per tan sols el 4,3\% dels homes. 


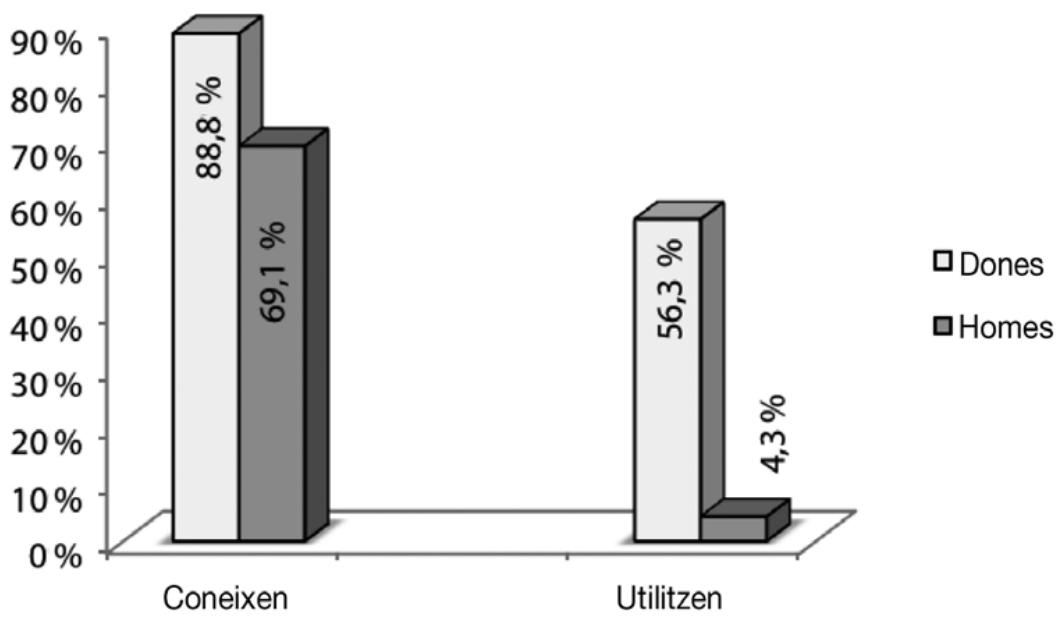

Gràfic 18.

Coneixement i ús del «Permís de lactància o acumulació d'hores de lactància» entre el PDI amb filles o fills menors de 13 anys

L'anàlisi de les dades corresponents al col·lectiu, dins del PDI, amb filles o fills menors de 13 anys ratifica l'escàs ús de 1' «Excedència per atenció a menors o familiars a càrrec seu», així i tot, pot destacar-se una clara diferència per sexe. 


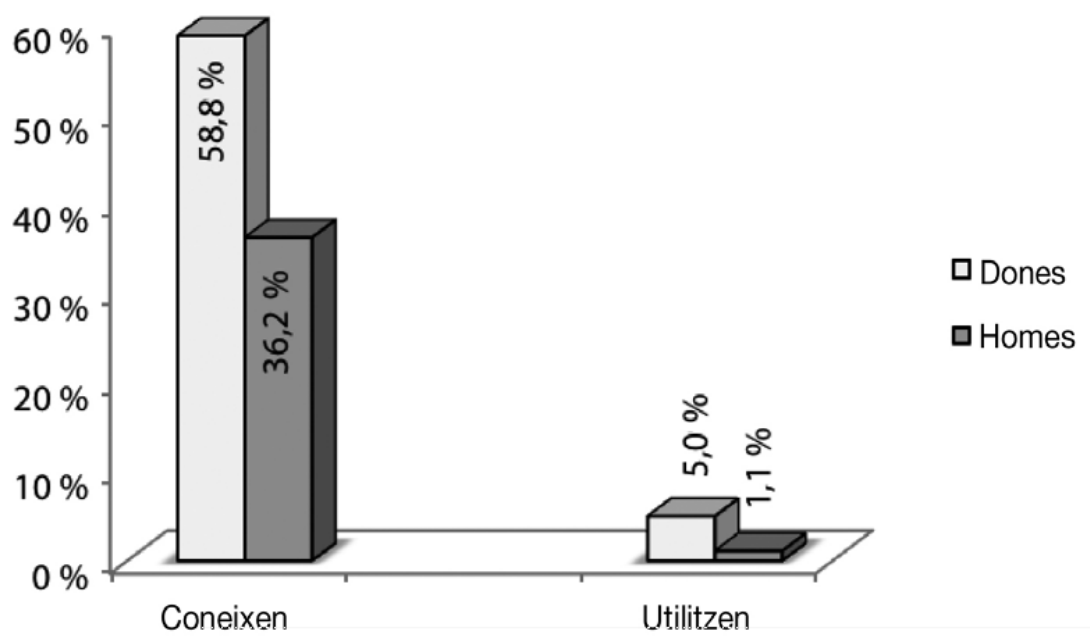

Gràfic 19.

Coneixement i ús de l'«Excedència per atenció a menors o familiars a càrrec seu» entre el PDI amb filles o fills menors de 13 anys

El resultat que ofereixen les dades de coneixement i ús de la mesura «Preferència en l'elecció d'horaris lectius» crida l'atenció. En primer lloc, que siga coneguda tan sols pel 43,1\% del PDI amb fills menors de 13 anys; encara que aquesta xifra supera la mitjana, suposa que la majoria del PDI que podria necessitar-la o beneficiar-se'n la desconeix. En segon lloc, es tracta d'una mesura que, a diferència de les anteriors, és coneguda per un percentatge més elevat d'homes que de dones, encara que, de nou, són més les dones que la utilitzen. Això apunta a un índex d'ús clarament més alt entre les dones que entre els homes. En tot cas, convindria indagar sobre el grau d'operativitat real d'aquesta mesura i dels obstacles per a la seua implementació en la pràctica, tal com s'ha al·ludit anteriorment en comentar les dades generals. 


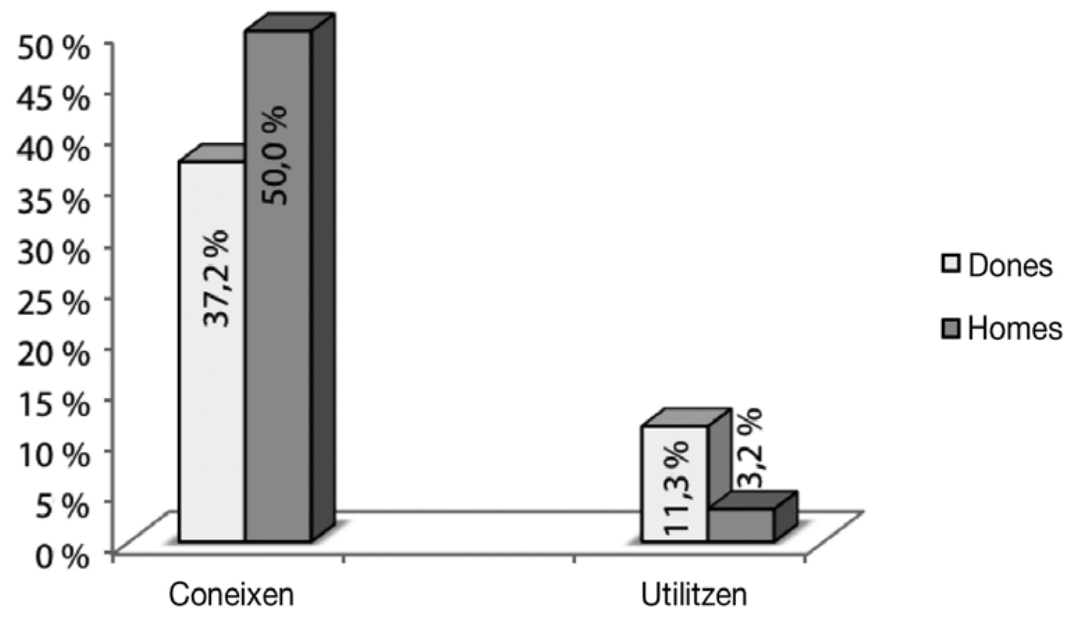

Gràfic 20.

Coneixement i ús de la «Preferència en l'elecció d'horaris lectius» entre el PDI amb filles o fills menors de 13 anys

L'«Adaptació/reducció de jornada per atenció a menors de fins a 12 anys» és l'última de les mesures en què s'observa un coneixement i un ús més elevat entre les persones del PDI amb menors de 13 anys a càrrec seu en comparació amb la mitjana general. Amb tot, és una mesura escassament utilitzada per les dones, el 3,8 \%, i quasi mai pels homes, 1'1,1\%. Tal com es comentava en l'apartat general, aquesta mesura suposa un clar detriment de les condicions salarials i de les oportunitats laborals, la qual cosa, unida al fet que els horaris del PDI siguen rígids tan sols en les tasques d'impartició de classes i realització de tutories presencials, podria explicar-ne la baixa utilització. 


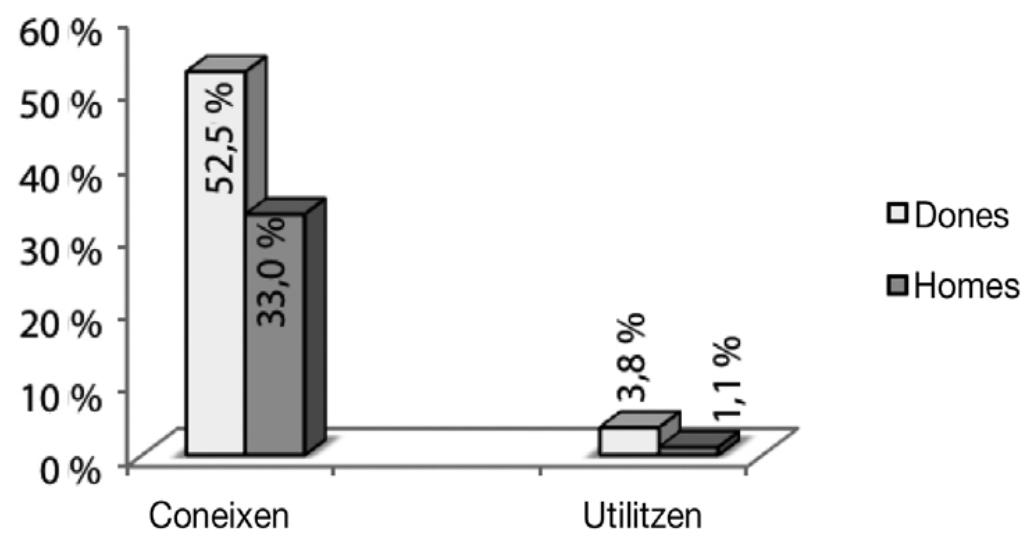

Gràfic 21 .

Coneixement i ús de l'«Adaptació/reducció de jornada per atenció a menors de fins a 12 anys» entre el PDI amb filles o fills menors de 13 anys

D'altra banda, els que tenen familiars dependents a càrrec seu coneixen totes les mesures per damunt de la mitjana, i destaca, de manera particular, l'ús que han realitzat de dues mesures directament relacionades amb aquesta situació vital.

En primer lloc, el «Permís per intervenció quirúrgica de familiars o malaltia familiar greu», que és conegut pel 66,7\% del PDI amb familiars dependents a càrrec seu, més de 15 punts per damunt de la mitjana, que se situa en el 51,3\%. L'ús d'aquesta mesura presenta una diferència molt més elevada; mentre que tan sols el 8,8 \% del total del PDI diu haver-la utilitzat, en el cas de les persones amb dependents a càrrec seu, la xifra s'eleva al 26,6 \%. Convé assenyalar, així mateix, que, en aquest col·lectiu, les diferències per sexe apareixen invertides quant a coneixement i ús. Així, mentre que és més elevat el coneixement d'aquesta mesura per part dels homes, l'ús és més alt entre les dones. 


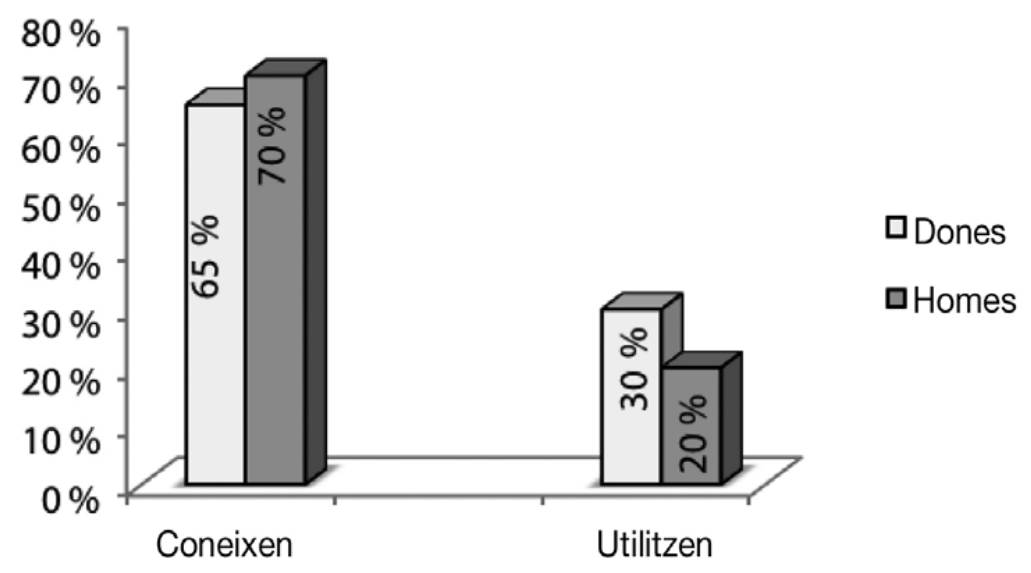

Gràfic 22.

Coneixement i ús del «Permís per intervenció quirúrgica de familiars o malaltia greu familiar» entre el PDI amb familiars dependents

En segon lloc, el «Permís per a visites mèdiques i assistència a persones menors, ancianes i amb discapacitat», que és conegut pel $43,3 \%$ de les persones amb familiars dependents a càrrec seu, més de 10 punts per damunt de la xifra corresponent al total del PDI, que se situa en el 32,7\%. Com en el cas anterior, encara que els homes coneixen la mesura en major proporció que les dones, són aquests les que més l'han utilitzada. 


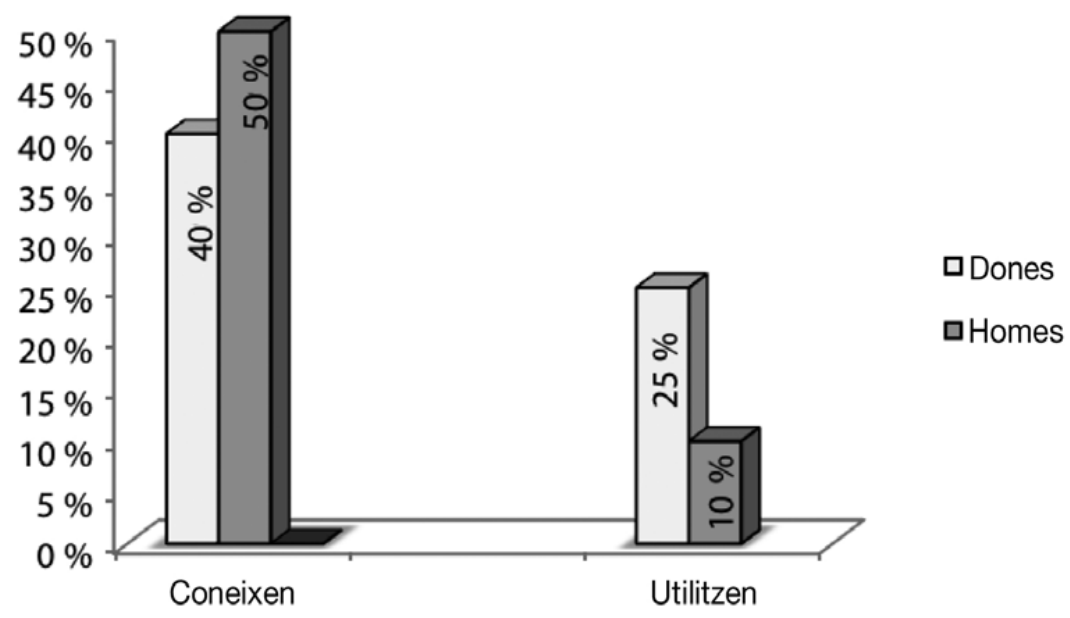

Gràfic 23.

Coneixement $\mathrm{i}$ ús del «Permís per a visites mèdiques $\mathrm{i}$ assistència a persones menors, ancianes i amb discapacitat» entre el PDI amb familiars dependents

\subsection{SIMILITUDS I DIFERÈNCIES EN ELS RESULTATS DEL PAS I DEL PDI}

\subsubsection{Coneixement de la normativa i del I Pla d'Igualtat}

La legislació en matèria de conciliació és més coneguda entre el PAS que entre el PDI, encara que, en termes globals, pràcticament sis de cada deu treballadores i treballadors pertanyents al PDI i al PAs de la Universitat Jaume I afirmen desconèixer-la.

Si les dades s'analitzen desagregades per sexe, s'observa en el PDI, igual que en el PAs, un percentatge més alt de dones que d'homes que afirma conèixer la legislació en matèria de conciliació, una diferència 
que, com es veurà més endavant, es manté en el coneixement de cada una de les mesures concretes en matèria de conciliació.

Respecte al coneixement del I Pla d'Igualtat de l'Usi, si es comparen les respostes obtingudes pel PDI amb les del PAS, es mostra de nou que aquest col·lectiu coneix més que el PDI el I Pla d'Igualtat de l'UJI. En particular, en aquest col·lectiu la resposta es comporta de manera inversa al que succeeix a la pregunta del coneixement de la normativa, en la mesura que un percentatge més elevat de PAs afirma conèixer el I Pla d'Igualtat de l'UJI en comparació amb el grau de coneixement manifestat sobre la legislació en matèria de conciliació. Aquest comportament de la resposta no té lloc en el cas del PDI, per al qual tant la legislació en matèria de conciliació com el I Pla d'Igualtat de l'UJI són desconeguts per a la majoria de les persones enquestades.

\subsubsection{Coneixement i ús de les distintes mesures}

Ambdós col-lectius coincideixen en el fet que el percentatge de dones que afirmen conèixer les distintes mesures de conciliació supera el dels homes en tots els casos. No obstant això, les diferències entre PAS i PDI són molt notables, presentant el PAS un grau de coneixement molt més elevat. Així, mentre que el PAS presenta xifres de coneixement superiors al $50 \%$ en dotze de les tretze mesures, en el cas del PDI tan sols són conegudes per la majoria dels seus components tres d'aquestes.

L'ús de cada una de les distintes mesures ofereix així mateix uns resultats molt contrastats entre PAS i PDI. Encara que de nou ambdós col·lectius han fet, en general, un ús més important de les mesures que, adoptant la forma de permisos, no comporten reduccions salarials, les dades mostren que és el PAS qui més les ha utilitzades. Les diferències més notables apareixen en les mesures següents: 


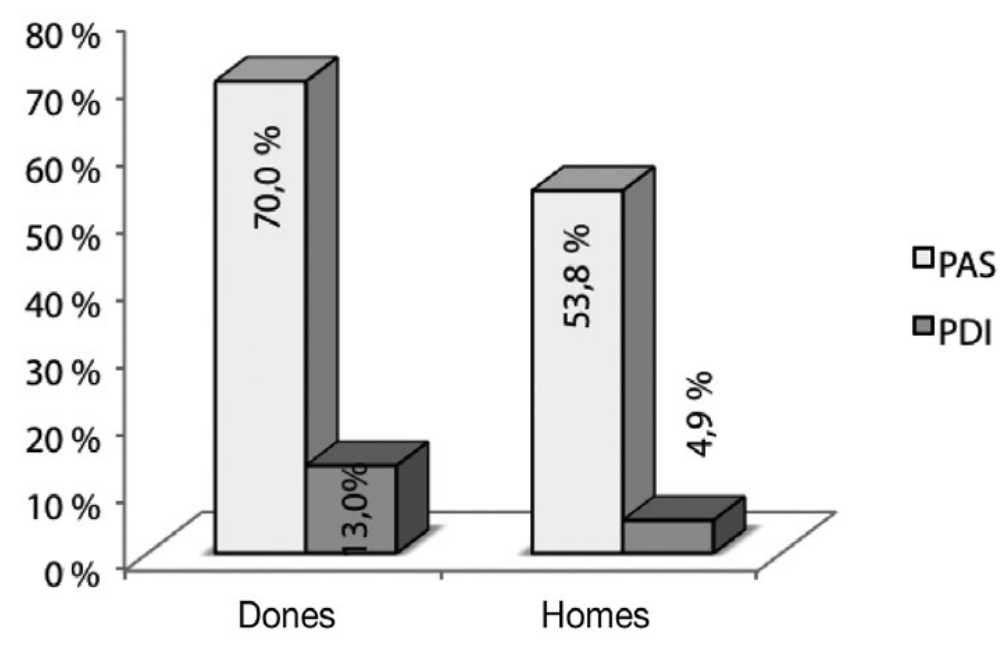

Gràfic 24.

Ús del «Permís per intervenció quirúrgica de familiars o malaltia greu familiar»

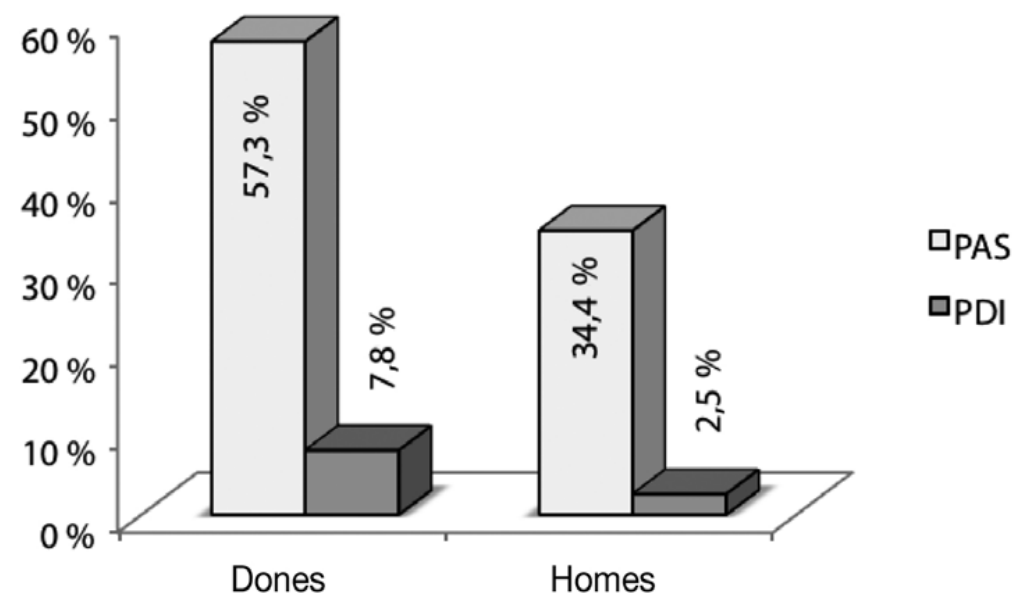

Gràfic 25.

Ús del «Permís per a visites mèdiques i assistència a persones menors, ancianes i amb discapacitat» 
Previsiblement, el principal motiu de la disparitat es trobe en l'organització, disposició i grau de flexibilitat de les jornades laborals de cada un dels col-lectius.

La mateixa raó podria estar en la base de les diferències observades en les mesures: «Adaptació/reducció de jornada per atenció a menors de fins a 12 anys» $\mathrm{i}$ «Excedència per atenció a menors o familiars a càrrec seu». Encara que el seu ús ha sigut minoritari per part del PAs, resulta significatiu atenent, sobretot, les diferències per sexe, ja que el percentatge de dones quasi sextuplica el d'homes en el primer cas i és deu vegades més alt en el segon, i en la comparació amb el PDI, ja que aquest últim n'ha fet un ús escassíssim.

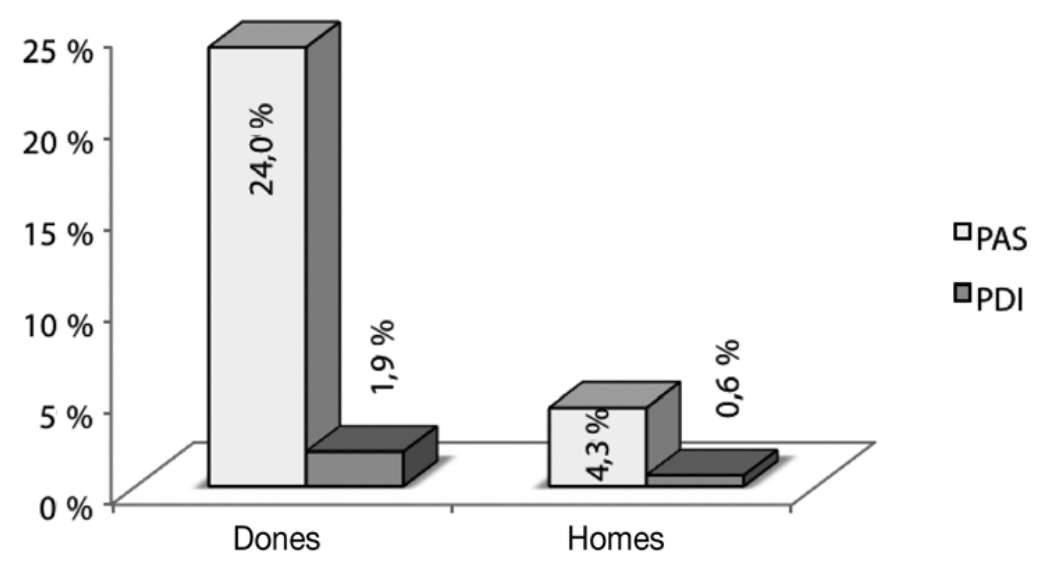

Gràfic 26.

Ús de l'«Adaptació/reducció de jornada per atenció a menors de fins a 12 anys» 


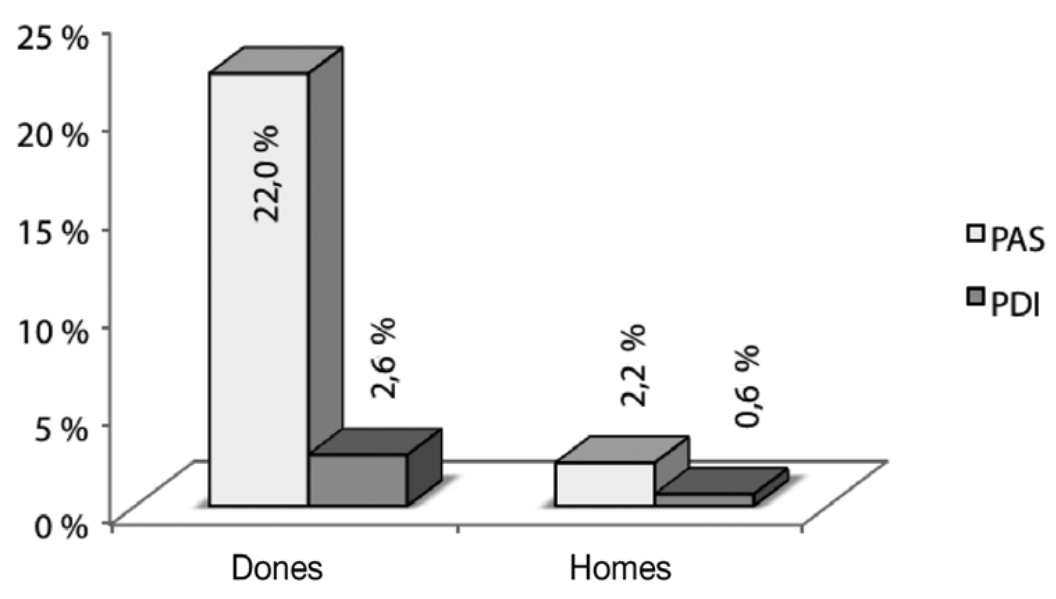

Gràfic 27.

Ús de l'«Excedència per atenció a menors o familiars a càrrec seu»

\subsection{CONCLUSIONS}

En termes generals, el personal que treballa a la Universitat Jaume I presenta un elevat desconeixement de la legislació en matèria de conciliació, sobretot entre les persones pertanyents al col·lectiu de PDI. Les diferències per sexe són notables tant entre el PDI com entre el PAS, sent les dones les que afirmen conèixer-la en nombre més alt de casos. El I Pla d'Igualtat de la Universitat es coneix un poc més, encara que la seua difusió pot qualificar-se igualment d'insuficient; per sexe, es redueixen les distàncies en comparació amb les dades anteriors, la qual cosa mostra que els homes estan molt més familiaritzats amb aquesta normativa concreta que amb la legislació general en matèria de conciliació. 
Sobre les distintes mesures investigades, pot concloure's que el grau de coneixement i ús de cada una d'aquestes és desigual i més elevat, en tots els casos, en el collectiu del pas que en el del PDI. En ambdós grups, tant el coneixement com l'ús dels recursos que faciliten la conciliació de la vida familiar i laboral són predominantment femenins. A pesar que la participació dels homes en les estratègies familiars de conciliació ha crescut en els últims anys, en part gràcies a les millores de les normatives existents respecte d'això i al canvi en la cultura empresarial/organitzacional tendent a afavorir la conciliació de la vida familiar, laboral i personal de la seua plantilla, aquesta encara és molt escassa en termes comparatius en el personal de la Universitat Jaume I.

Encara que s'observa un ús molt més elevat de les mesures entre el PAS que entre el PDI, ambdós col-lectius presenten una tendència comuna: s'utilitzen sobretot aquelles mesures que adopten la forma de permisos i que no impliquen reducció salarial o minva de les oportunitats de carrera professional. En aquests casos, a més, les diferències per sexe solen ser menors que en la resta.

\section{LA DISTRIBUCIÓ DE LES TASQUES DOMÈSTIQUES I D'ATENCIÓ EN ELS TREBALLADORS I TREBALLADORES DE LA UNIVERSITAT JAUME I}

\subsection{DESCRIPTIUS GENERALS}

La mostra de treballadors i treballadores PAS de la Universitat Jaume I està composta per 243 persones $(41 \%$ del total). D'aquestes 243 , un $37,5 \%$ són homes i un 60,5 \% són dones. Quant a l'edat, un $6 \%$ de PAS tenen menys de 33 anys; un 28,6\%, entre 33 i 39 anys; un 48,4\%, entre 40 i 49 anys, i un 13,7 \%, més de 50 anys. La mostra de treballadors $i$ treballadores PDI de la Universitat Jaume I està composta per 318 membres (24\% del total). D’aquests 318, un $52 \%$ són homes i un 48 \% són 
dones. Quant a l'edat, el $10 \%$ té menys de 33 anys; el $25 \%$, entre 33 i 39 anys; el $48 \%$, entre 40 i 49 anys, i el $17 \%$, més de 50 anys.

Podem evidenciar que han respost majoritàriament dones en el collectiu PAS $(62 \%)$ i majoritàriament homes en el col·lectiu PDI (52\%). D'altra banda, el rang d'edat predominant de les persones enquestades en ambdós col·lectius se situa entre 40 i 49 anys.
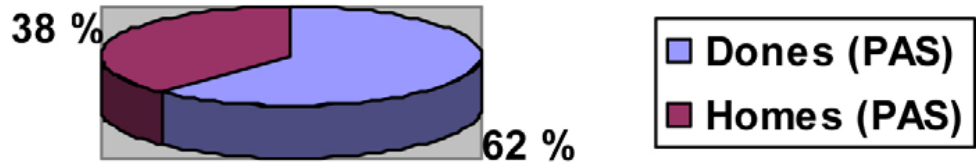

Gràfic 1.

Percentatge de dones i homes en el PAS
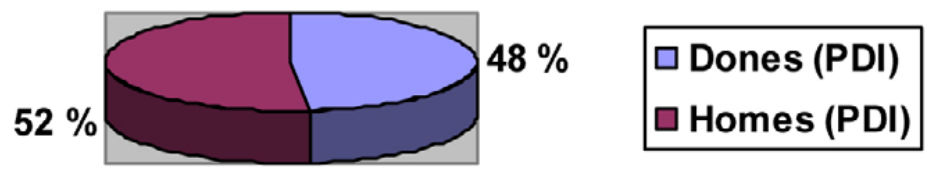

Gràfic 2.

Percentatge de dones i homes en el PDI

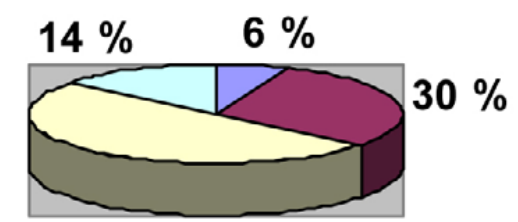

$50 \%$ $\square$ Menys de 33

$\square$ Entre 33 i 39

$\square$ Entre 40 i 49

Més de 50

Gràfic 3.

Rang d'edat del PAS 


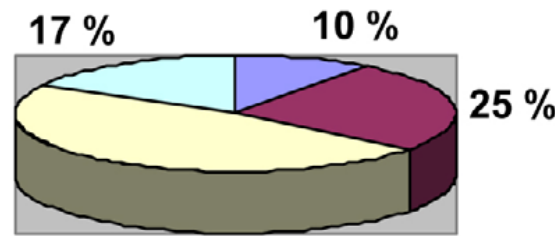

$48 \%$

$\square$ Menys de 33

$\square$ Entre 33 i 39

Entre 40 i 49

Més de 50

Gràfic 4.

Rang d'edat del PDI

Quant al nivell d'estudis, en el col-lectiu PAs un $1 \%$ té estudis primaris; un $14 \%$, estudis secundaris; un $22 \%$ posseeix una diplomatura; un $49 \%$, una llicenciatura; un $1 \%$ té estudis de grau; un $8 \%$, de màster, i un $5 \%$, de doctorat. En el col-lectiu PDI, un $0,3 \%$ té diplomatura; un $12 \%$, llicenciatura; un $0,3 \%$, estudis de grau; un $12 \%$, de màster; i un $76 \%$, doctorat. Podem evidenciar que en el col-lectiu PAs la majoria compta amb diplomatura i llicenciatura. En el col-lectiu PDI, la majoria compta amb estudis de doctorat. En suma, podem afirmar que ambdós col·lectius, açò és, PAS i PDI, tenen un nivell d'estudis alt.

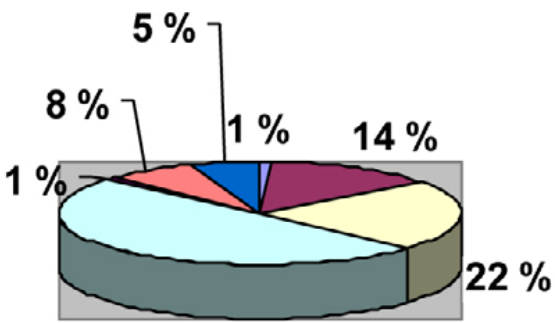

$49 \%$

\begin{tabular}{|l|}
\hline$\square$ Primaris \\
$\square$ Secundaris \\
$\square$ Diplomatura \\
$\square$ Llicenciatura \\
$\square$ Grau \\
$\square$ Màster \\
$\square$ Doctorat \\
\hline
\end{tabular}

Gràfic 5 .

Nivell d'estudis del PAS 


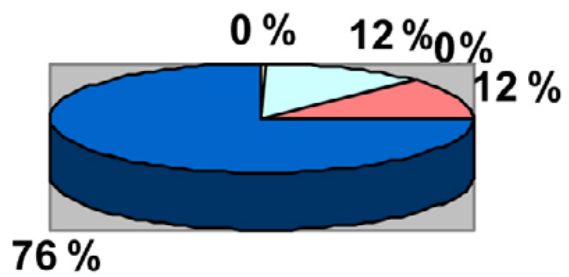

$\square$ Primaris
$\square$ Secundaris
$\square$ Diplomatura
$\square$ Llicenciatura
$\square$ Grau
$\square$ Màster
$\square$ Doctorat

Gràfic 6 .

Nivell d'estudis del PDI

Quant a la categoria laboral del col·lectiu PAs, el $19 \%$ de les persones enquestades són grup A sense direcció; el 6,5 \% són grup A amb direcció; un 8,9 \% són grup B; un 38,3 \% són grup $\mathrm{C}$ o D sense direcció, i un 19,4 \% són grup C o D amb direcció. Per tant, la categoria laboral predominant entre les persones del col·lectiu del PAs que han respost a l'enquesta és el grup C o D sense direcció.

En el col·lectiu PDI, un 7,5 \% són catedràtics o catedràtiques; un $29,9 \%$ són titulars d'universitat; un $0,3 \%$ són catedràtics o catedràtiques d'escola; un 5,3 \% són titulars d'escola; un 11,6 \% són contractats doctors o contractades doctores; un 1,3\% és professorat collaborador; un 5,3 \% és ajudant doctor o ajudanta doctora; un 3,5\% és ajudant personal investigador; un 5,3\% és contractat doctor o contractada doctora; un 1,9\% és «altre personal investigador»; un 20,4 $\%$ és professorat associat; i un 3,5\% és personal becari. De tot el collectiu PDI, un $42 \%$ informa tenir responsabilitats de gestió. 


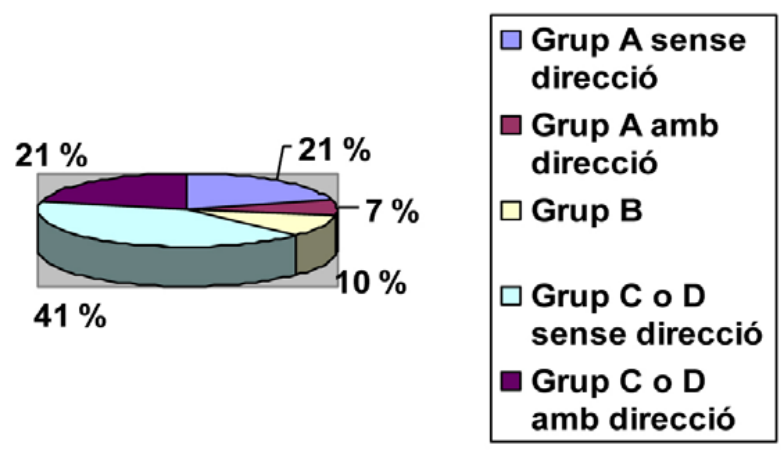

Gràfic 7.

Categoria laboral del PAS

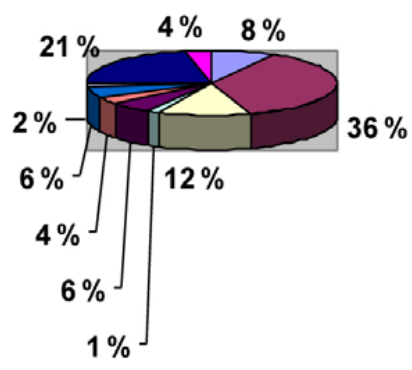

\begin{tabular}{|l|}
\hline$\square$ Catedràtic/a \\
$\square$ Titular \\
$\square$ Contractat/ada \\
doctor/a \\
$\square$ Professorat \\
col·laborador/a \\
$\square$ Ajudant/a \\
doctor/a \\
$\square$ Ajudant/a \\
personal \\
investigador \\
Contractat/ada \\
doctor/a \\
$\square$ Altre personal \\
investigador \\
$\square$ Professorat \\
associat \\
$\square$ Personal becari
\end{tabular}

Gràfic 8 .

Categoria laboral del PDI 


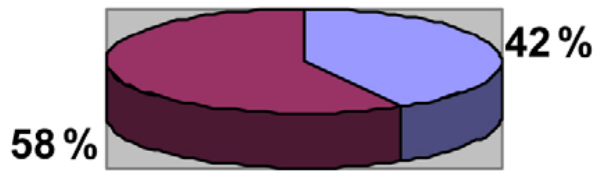

$\square$ Amb gestió

$\square$ Sense gestió

Gràfic 9.

PDI amb càrrecs de gestió

\subsection{RESULTATS SOBRE LES RESPONSABILITATS DOMĖSTIQUES DEL PAS I DEL PDI}

En el següent apartat es reflecteix la distribució de les tasques de la llar entre homes i dones dels col-lectius PAS i PDI. Les tasques de la llar considerades en aquest apartat van ser: cuinar, tasques de neteja, planxar roba, reparacions domèstiques i compra setmanal.

\subsubsection{Realització de tasques domèstiques}

Taula 1.

Exercici de tasques de la llar (PAS)

\begin{tabular}{llcc} 
Tasques & Total PAS & Dones PAS & Homes PAS \\
Cuinar & $43,9 \%$ & $59,1 \%$ & $28,7 \%$ \\
Tasques de neteja & $41,1 \%$ & $55,3 \%$ & $26,9 \%$ \\
Planxar roba & $30 \%$ & $46 \%$ & $14 \%$ \\
$\begin{array}{l}\text { Reparacions domèstiques (ex., } \\
\text { reparar la cisterna del wc) }\end{array}$ & $33,5 \%$ & $57 \%$ & $10 \%$ \\
Compra setmanal & $50 \%$ & $50 \%$ & $50 \%$ \\
\hline
\end{tabular}


Taula 2.

Exercici de tasques de la llar (PDI)

\begin{tabular}{lccc} 
Tasques & Total PDI & Dones PDI & Homes PDI \\
Cuinar & $37,2 \%$ & $52,4 \%$ & $22,1 \%$ \\
Tasques de neteja & $44,6 \%$ & $46,2 \%$ & $43 \%$ \\
Planxar roba & $32,7 \%$ & $38,5 \%$ & $26,9 \%$ \\
$\begin{array}{l}\text { Reparacions domèstiques (ex., } \\
\text { reparar la cisterna del wc) }\end{array}$ & $40,1 \%$ & $42,6 \%$ & $37,6 \%$ \\
Compra setmanal & $47,5 \%$ & $55 \%$ & $40 \%$ \\
\hline
\end{tabular}

En general, els resultats evidencien en ambdós col·lectius que majoritàriament les dones són les que realitzen les tasques de la llar, això és, cuinar, tasques de neteja, planxar roba, reparacions domèstiques $i$ compra setmanal. Conjuntament, es pot evidenciar que les tasques que tenen una atribució tradicional de rols a cada sexe, és a dir, les tasques considerades típicament femenines (ex., cuinar o planxar) les continuen realitzant majoritàriament les dones, $\mathrm{i}$ en les tasques típicament masculines (ex., reparacions domèstiques) augmenta el percentatge d'homes en aquesta tasca específica. No obstant això, són les dones d'ambdós col·lectius les que en un percentatge més alt realitzen les reparacions domèstiques a casa. En el cas de la compra setmanal, al contrari, s'observa un percentatge igualat de dones i homes que afirmen realitzar aquesta tasca en ambdós col·lectius.

\subsubsection{Atenció a fills i filles menors de 18 anys que viuen a la llar}

De la mostra total de PAs, un $74 \%$ dels enquestats manifesta tenir fills i filles menors d'edat amb què conviuen i un $26 \%$ que no en té. 
De la mostra total de PDI, un $70 \%$ dels enquestats manifesta tenir fills i filles menors d'edat amb què conviu i un $30 \%$ que no en té. Per tant, podem evidenciar que en ambdós col·lectius, majoritàriament (aproximadament un $70 \%$ ), són treballadors i treballadores que tenen fills i filles menors de 18 anys a càrrec seu, la qual cosa significa que en ambdós col·lectius són responsables de l'atenció i manutenció de menors d'edat.

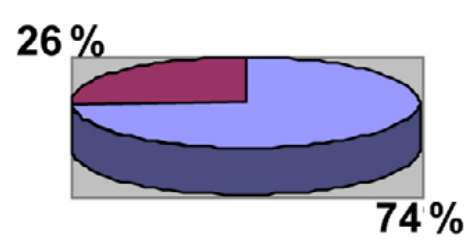

Tenen fills/filles

No tenen

fills/filles

Gràfic 10.

Fills i filles menors d'edat (PAS)

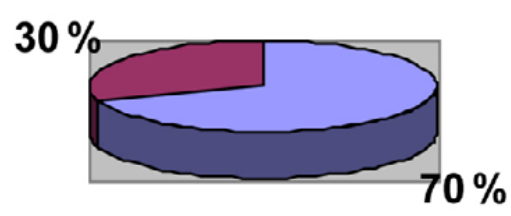

Tenen fills/filles

$\square$ No tenen fills/filles

Gràfic 11.

Fills i filles menors d'edat (PDI) 


\subsubsection{Activitats realitzades en l'atenció a menors}

En el següent apartat es reflecteix la distribució de les activitats realitzades en l'atenció de menors entre homes i dones dels col·lectius PAS i PDI. Les activitats considerades en aquest apartat van ser: acompanyar els fills i filles al col·legi, assistir a reunions amb tutors o docents, ajudar en les tasques escolars, supervisar la higiene personal dels fills i filles per a anar al col·legi i portar-los a assistències i revisions mèdiques.

Taula 3.

Activitats realitzades en l'atenció a menors (PAS)

\begin{tabular}{lccc}
$\begin{array}{l}\text { Activitats realitzades en l'atenció } \\
\text { a menors }\end{array}$ & $\begin{array}{c}\text { Total } \\
\text { PAS }\end{array}$ & $\begin{array}{c}\text { Dones } \\
\text { PAS }\end{array}$ & $\begin{array}{c}\text { Homes } \\
\text { PAS }\end{array}$ \\
$\begin{array}{l}\text { Acompanyar els fills/filles menors al } \\
\text { col-legi }\end{array}$ & $49,6 \%$ & $35,6 \%$ & $14 \%$ \\
$\begin{array}{l}\text { Assistir a reunions amb tutors o do- } \\
\text { cents }\end{array}$ & $73,6 \%$ & $52,5 \%$ & $21,1 \%$ \\
$\begin{array}{l}\text { Ajudar els fills/filles en les tasques } \\
\text { escolars }\end{array}$ & $58,4 \%$ & $42,6 \%$ & $15,8 \%$ \\
$\begin{array}{l}\text { Supervisar la higiene personal per a } \\
\text { anar al col·legi }\end{array}$ & $66,9 \%$ & $56,4 \%$ & $10,5 \%$ \\
$\begin{array}{l}\text { Portar els fills/filles a les assistències } \\
\text { i revisions mèdiques }\end{array}$ & $81 \%$ & $56,4 \%$ & $24,6 \%$ \\
\hline
\end{tabular}


Taula 4.

Activitats realitzades en l'atenció a menors (PDI)

\begin{tabular}{lccc}
\multicolumn{1}{c}{$\begin{array}{c}\text { Activitats realitzades en } \\
\text { l'atenció a menors }\end{array}$} & $\begin{array}{c}\text { Total } \\
\text { PAS }\end{array}$ & $\begin{array}{c}\text { Dones } \\
\text { PAS }\end{array}$ & $\begin{array}{c}\text { Homes } \\
\text { PAS }\end{array}$ \\
$\begin{array}{l}\text { Acompanyar els fills/filles menors al } \\
\text { col·legi }\end{array}$ & $82,4 \%$ & $50,3 \%$ & $32,1 \%$ \\
$\begin{array}{l}\text { Assistir a reunions amb tutors o do- } \\
\text { cents }\end{array}$ & $68,6 \%$ & $46,4 \%$ & $22,2 \%$ \\
$\begin{array}{l}\text { Ajudar els fills/filles en les tasques } \\
\text { escolars }\end{array}$ & $71,2 \%$ & $32,4 \%$ & $38,8 \%$ \\
$\begin{array}{l}\text { Supervisar la higiene personal per a } \\
\text { anar al col-legi }\end{array}$ & $84,9 \%$ & $50,4 \%$ & $34,5 \%$ \\
$\begin{array}{l}\text { Portar els fills/filles a les assistències } \\
\text { i revisions mèdiques }\end{array}$ & $84 \%$ & $58,8 \%$ & $25,2 \%$ \\
\hline
\end{tabular}

A la vista dels resultats podem interpretar que són, majoritàriament, les dones d'ambdós col·lectius les que es fan càrrec habitualment de les tasques relacionades amb l'atenció dels fills i filles. Aquest resultat és coincident amb els resultats de les tasques en la llar, on també són les dones d'ambdós col·lectius les que assumeixen la responsabilitat de realitzar aquestes tasques.

\subsubsection{Familiars en situació de dependència a càrrec seu}

De la mostra total de PAS, un $12 \%$ de les persones enquestades manifesta tenir familiars en situació de dependència a càrrec seu i un $88 \%$ que no en té. De la mostra total de PDI, un $10 \%$ de les persones enquestades manifesta tenir familiars en situació de dependència a càrrec seu i un $90 \%$ que no en té. Per tant, podem evidenciar que en 
ambdós col·lectius, majoritàriament (aproximadament un $85 \%$ ), són treballadors i treballadores que no tenen familiars en situació de dependència a càrrec seu. No obstant això, és important tenir en compte que el percentatge d'ambdós col·lectius que sí que té familiars en situació de dependència (aproximadament un $11 \%$ ), té responsabilitats i tasques d'atenció. Entre aquestes, cal acompanyar-los a les revisions mèdiques, controlar la medicació i fer-se càrrec de la higiene personal. Dins d'aquest percentatge (aproximadament un $11 \%$ ), un $80 \%$, a més, té menors a càrrec seu a casa, la qual cosa comporta una doble responsabilitat.

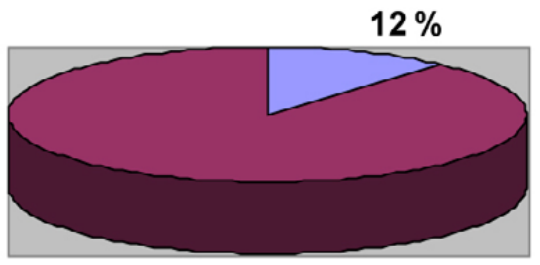

$\square$ Té dependents a
càrrec seu
$\square$ No té dependents a
càrrec seu

$88 \%$

Gràfic 12.

Familiars en situació de dependència (PAS)

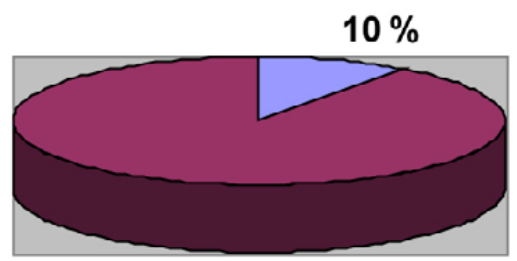

$\square$ Té dependents a
càrrec seu
$\square$ No té dependents a
càrrec seu

Gràfic 13.

Familiars en situació de dependència (PDI) 
Com a conclusions generals d'aquest apartat de l'enquesta és interessant destacar que en ambdós col·lectius el rang d'edat predominant se situa entre 40 i 49 anys, que està prop del $50 \%$ en ambdós collectius. Aquesta informació és de gran rellevància pel fet que es tracta d'una població que, en general, ja té una vida consolidada, això és, parella, fills i filles (aproximadament un $70 \%$ indica tenir descendència), persones en situació de dependència (aproximadament un $10 \%$ indica tenir persones a càrrec seu), responsabilitats, per la qual cosa les mesures que es prenguen dins de la Universitat Jaume I haurien de considerar els aspectes que milloraren les seues condicions de conciliació i coresponsabilitat.

A més, és interessant constatar que en aquesta enquesta es contemplen específicament tasques d'atenció física i material referides a cura de fills i filles i/o persones en situació de dependència. Seria molt convenient fer notar que les tasques d'atenció psicològica també són importants pel fet que contemplen un esforç tant emocional com físic. En aquest context, Mabel Burin reflexiona sobre la maternitat com «l'altre treball invisible» (Sau, 1995: 101). Per tant, a l'hora de proposar iniciatives per a conciliar vida laboral, personal i familiar, caldria contemplar les tasques d'atenció psicològica a menors.

Concretament, els resultats en tots els apartats considerats en l'enquesta relacionats amb les responsabilitats domèstiques (p. ex., exercici de tasques de la llar, atenció a menors, atenció a familiars en situació de dependència) del PAs i el PDI, ens indiquen que aquestes responsabilitats estan dutes a terme, majoritàriament, per les dones integrants d'ambdós col-lectius. L'anterior ens assenyala que el rol que històricament s'associa a aquest tipus de tasques es manté en l'actualitat realitzat per les dones. Per tant, en aquest context és pertinent parlar del concepte de la maternitat ampliada, és a dir, l'extensió dels processos de solidaritat familiar i social, que poden considerar-se també com fer-se càrrec de l'altre, no per obligació jurídica i laboral, sinó a causa de la preocupació ètica que es deriva de l'assumpció personalista de la dimensió materna (Di Nicola, 1991: 60). I tot això es tradu- 
eix, tal com s'ha plasmat en la introducció d'aquest llibre, en el fet que les dones tenen una doble càrrega o doble jornada que sens dubte les fa més vulnerables a danys psicosocials i/o físics (Cifre, Salanova i Franco, 2011).

Plantejar solucions, com per exemple, i per a començar, la conscienciació sobre aquest fenomen en l'ambient universitari, o bé informar sobre les pràctiques dutes a terme a la Universitat que permeten la conciliació i la coresponsabilitat, resulta ser un punt clau per a millorar aquesta situació en el futur.

\section{PERCEPCIÓ D'EQUILIBRI EN EL REPARTIMENT DE LES TASQUES DOMÈSTIQUES I D'ATENCIÓ}

En aquest punt tractarem la percepció que té la plantilla de l'UJI respecte a dues qüestions: en primer lloc, ens interessa conèixer si les persones enquestades consideren que hi ha un equilibri entre la seua parella i ell o ella en el repartiment de les tasques domèstiques i d'atenció als fills i filles i, en segon lloc, volem obtenir informació sobre la percepció que tenen en relació a l'equilibri entre la vida personal, laboral i familiar.

L'objectiu d'incloure aquestes preguntes té com a finalitat, d'una banda, esbrinar si s'han produït canvis en el sistema de gèneres relacionats amb la distribució de les tasques domèstiques i d'atenció, és a dir, si amb la incorporació de les dones al mercat laboral s'ha produït una coresponsabilitat en el repartiment de les dites tasques, això és, que si tant les dones com els homes són ambdós responsables de la seua realització.

Autors com ara Rivero Recuento (2005) considera que ha de revisar-se el concepte de conciliació i identificar-lo més amb el de coresponsabilitat, en el sentit d'equilibrar l'esforç que han de realitzar tant els homes com les dones en la realització de les tasques domèstiques 
i d'atenció, ja que en cas contrari es considera una discriminació vers les dones.

D'altra banda, i encara que fonamentalment en el nostre estudi ens centrem en la conciliació entre la vida laboral i la vida familiar, avui en dia es parla més de conciliació entre els tres àmbits o espais al·ludits, el laboral, el familiar i el personal, ja que no es pot obviar aquest últim en l'organització de la vida de les persones. ${ }^{73}$

La inclusió d'una pregunta sobre la percepció que tenen les persones enquestades sobre l'existència d'un equilibri entre la seua vida laboral, familiar i personal ens mostrarà la consideració que té la plantilla de l'Us sobre l'articulació dels continguts dels seus diferents temps.

Recordem que es tracta d'una percepció, vocable que el diccionari María Moliner defineix com «Acció de percebre. Idea: representació d'una cosa en la ment». En aquesta pregunta, doncs, ens referim exclusivament a la percepció que es té sobre el tema, no fa referència als comportaments reals, ja tractats en un altre punt de la present anàlisi sobre els resultats de l'enquesta.

D'aquesta manera, les respostes ens faciliten informació sobre com es percep la realització de la coresponsabilitat en la parella, si les persones enquestades consideren que hi ha un equilibri en el repartiment de les tasques o si continuen predominant comportaments asimètrics en el seu repartiment tal com succeïa en el sistema de gèneres tradicional.

En aquesta pregunta, juntament amb les respostes expressades en «Estic d'acord/en desacord», s'incloïa l'opció «indiferent». Encara que aquesta resposta no està reflectida en les taules, n'informarem quan el percentatge obtingut en la dita resposta siga cridaner. ${ }^{74}$

73. Això va influir en el fet que normatives com ara la Llei 3/2007 inclogueren referències a aquesta qüestió en el capítol II, article 44, «Els drets de conciliació de la vida personal, familiar i laboral».

74. L'alt nombre de respostes «indiferent» en les diverses preguntes analitzades en aquest apartat queda reflectit en la representació gràfica de les taules, les quals només consideren les respostes «Estic d'acord» $\mathrm{i}$ «Estic en desacord». 
El present punt l'estructurem en tres subapartats: en primer lloc, ens referirem a la percepció sobre si hi ha o no un equilibri en el repartiment de les tasques domèstiques entre la persona enquestada i la seua parella; en segon lloc, i amb l'objectiu de diferenciar una activitat i l'altra, ens centrem en el tema de l'atenció de fills i filles, i finalment, exposarem els resultats proporcionats per part del personal enquestat sobre si consideren que hi ha un equilibri entre les seues necessitats personals, familiars i laborals.

\subsection{EN EL REPARTIMENT DE TASQUES DOMÈSTIQUES}

Iniciem l'exposició amb les respostes proporcionades sobre si la persona enquestada considera que hi ha un equilibri en el repartiment de les tasques domèstiques entre ella i la seua parella.

Taula 1.

Considere que hi ha equilibri en el repartiment de tasques domèstiques entre la meua parella i jo

\begin{tabular}{lcccc} 
& \multicolumn{2}{c}{ PAS \% } & \multicolumn{2}{c}{ PDI \% } \\
& Homes & Dones & Homes & Dones \\
\hline $\begin{array}{l}\text { Estic } \\
\text { d'acord }\end{array}$ & 69,1 & 49,5 & 55,2 & 48,7 \\
$\begin{array}{l}\text { Estic en } \\
\text { desacord }\end{array}$ & 9,6 & 28,6 & 16,0 & 26,0 \\
\hline
\end{tabular}

En la gràfica s'observen amb major nitidesa les dades exposades. 


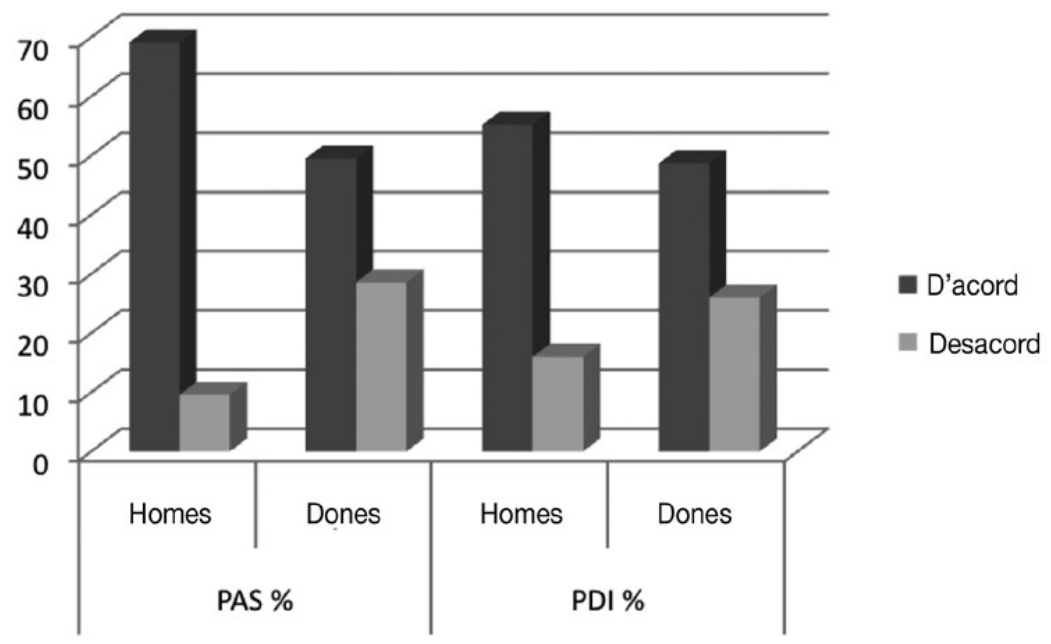

Gràfic 1.

Considere que hi ha equilibri en el repartiment de tasques domèstiques entre la meua parella $\mathrm{i}$ jo

Les respostes manifesten una discrepància quant a la percepció de l'asimetria en el repartiment de les responsabilitats domèstiques. Els homes manifesten una visió més positiva respecte a això, mentre que les dones no pareixen estar tant d'acord en l'existència d'un equilibri: no arriben al $50 \%$ les que expressen estar-hi d'acord.

És a dir, que els homes consideren que la coresponsabilitat en la distribució de les tasques domèstiques és més alta del que perceben les dones, la qual cosa produeix una discrepància notable.

Les dones del PAs i del PDI reflecteixen una homogeneïtat entre elles molt diferent de la mostrada per homes del PDI i del PAs els quals expressen unes diferències entre l'acord i el desacord molt significatives, tal com es reflecteix en la taula i gràfic 1. 
La distància en les opinions entre dones i homes del PDI és menor que l'observada en el PAs, col·lectiu que expressa respostes més polaritzades entre els sexes.

La diferent percepció que tenen les dones i els homes manifesta que en les qüestions domèstiques, el llindar que determina què està net o ordenat és distint (Martínez García, 2013), és a dir, que es veu de diferent manera per part d'un sexe o de l'altre en funció de la socialització de gènere rebuda.

Si tenim en compte les diferències existents dins de cada un dels col·lectius considerats, el PAS i el PDI, en relació a una sèrie de variables com ara l'edat, el nombre de fills i la categoria laboral, es perfila quins grups tenen una percepció d'equilibri més alta o més baixa respecte a la realització de les tasques domèstiques.

En primer lloc, es mostren els resultats respecte als grups d'edat.

Taula 2.

Percepció que hi ha un equilibri en el repartiment de tasques domèstiques entre la meua parella i jo, per grups d'edat (PAS)
Menys de 33
34-39
$40-49$
Más de 50
anys \%
anys \%
anys \%
anys \%

Homes Dones Homes Dones Homes Dones Homes Dones

Estic en

desacord

$0,0 \quad 11,1 \quad 6,9 \quad 33,4 \quad 14,6 \quad 26,6 \quad 7,1 \quad 40,0$

\begin{tabular}{llllllll} 
Estic d'acord $\quad 83,0$ & 44,4 & 75,9 & 54,8 & 70,2 & 53,1 & 50,0 & 25,0 \\
\hline
\end{tabular} 


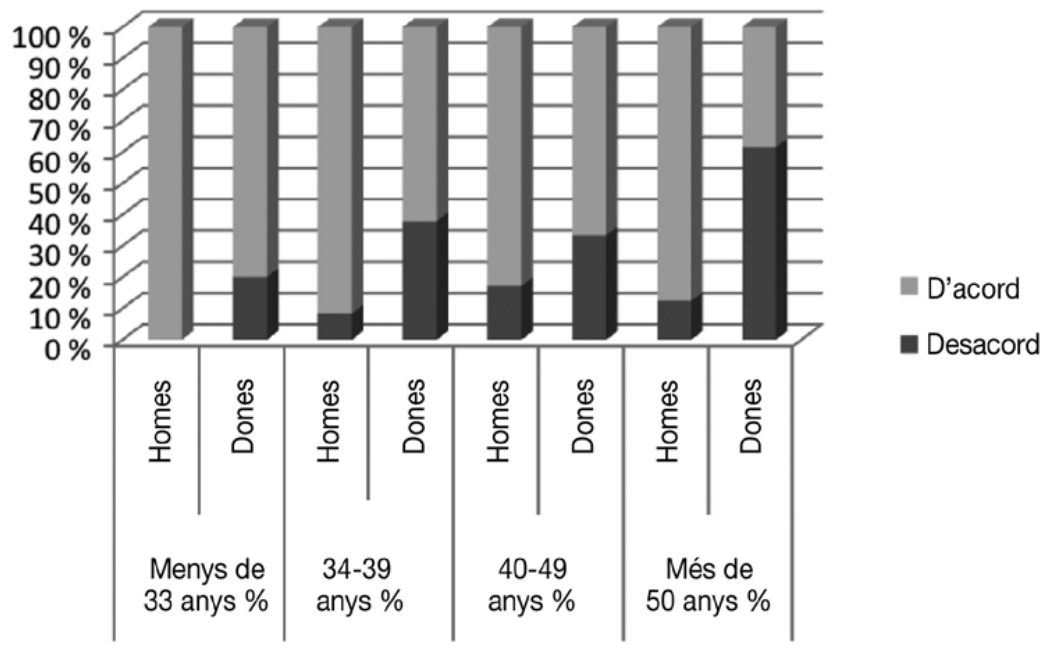

Gràfic 2.

Percepció que hi ha un equilibri en el repartiment de tasques domèstiques entre la meua parella i jo, per grups d'edat (PAS)

Les respostes dels homes d'aquest col·lectiu, majoritàriament $\mathrm{d}$ 'acord amb què el repartiment és equilibrat, mostren una variació de 33 punts percentuals entre els majors de 51 anys i els menors de 30 anys. És, doncs, inversament proporcional a l'edat: com més edat, menys nivell d'acord amb l'existència d'un equilibri en el repartiment de tasques.

Respecte del nivell de desacord en les dones, són quasi 30 punts percentuals la variació en les respostes entre les menors de 30 anys $i$ les majors de 51 anys. El nivell de percepció de l'asimetria en la coresponsabilitat en les tasques domèstiques s'incrementa amb l'edat, resultat segurament d'un major contacte amb la «realitat» de la vida familiar i el que aquesta suposa d'exercici de tasques o també a un grau de conscienciació més alt i d'haver estat exposada a campanyes de sensibilització sobre aquests temes. 
Taula 3.

Percepció que hi ha un equilibri en el repartiment de tasques domèstiques entre la meua parella i jo, per grups d'edat (PDI)

\begin{tabular}{lccccccccc} 
& \multicolumn{2}{c}{$\begin{array}{c}\text { Menys de 33 } \\
\text { anys \% }\end{array}$} & \multicolumn{2}{c}{$\begin{array}{c}\text { 34-39 } \\
\text { anys \% }\end{array}$} & \multicolumn{2}{c}{$\begin{array}{c}\text { 40 -49 } \\
\text { anys \% }\end{array}$} & \multicolumn{2}{c}{$\begin{array}{c}\text { Más de 50 } \\
\text { anys \% }\end{array}$} \\
& Homes & Dones & Homes & Dones & Homes & Dones & Homes & Dones \\
\hline $\begin{array}{l}\text { Estic en } \\
\text { desacord }\end{array}$ & 9,1 & 25,0 & 25,0 & 31,2 & 15,0 & 24,6 & 13,9 & 17,7 \\
Estic d'acord & 45,5 & 50 & 59,4 & 55,9 & 58,8 & 47,8 & 50,0 & 58,8 \\
\hline
\end{tabular}

Com mostren les dades per al PDI, el col·lectiu que mostra més desacord en la percepció que hi ha un equilibri en el repartiment de tasques domèstiques és el de dones PDI entre els 34 i els 39 anys. Respecte al grup d'edat que més coincideix amb l'equilibri en el repartiment de tasques, se situa el professorat femení de més de 50 anys i el masculí d'entre 40-49 anys.

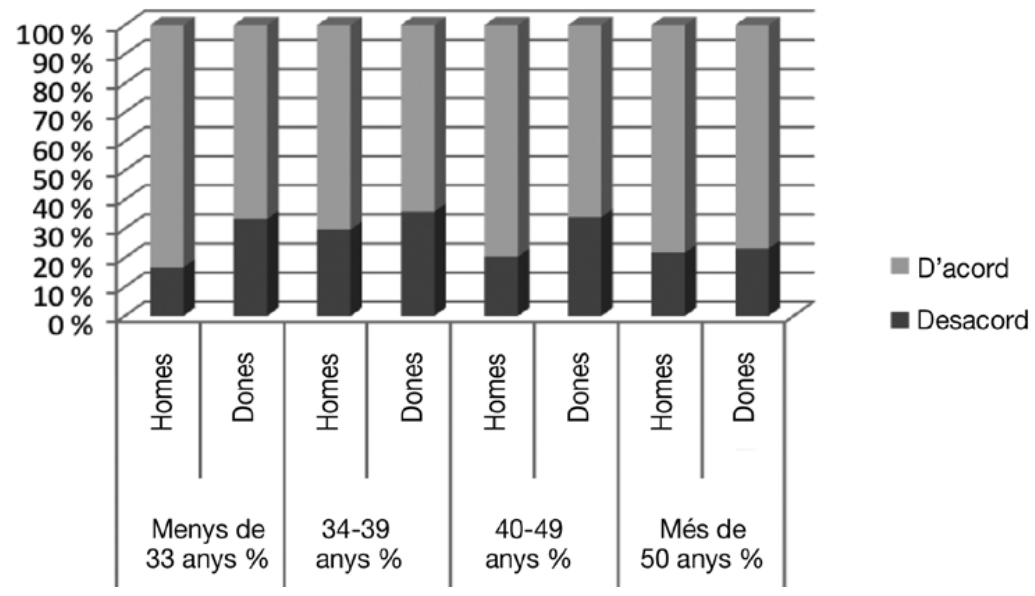

Gràfic 3.

Percepció que hi ha un equilibri en el repartiment de tasques domèstiques entre la meua parella i jo, per grups d'edat (PDI) 
Vegem a continuació si el nombre de fills i filles té alguna cosa a dir en la percepció sobre l'equilibri en el repartiment.

\section{Taula 4.}

Percepció sobre el repartiment equilibrat de tasques domèstiques segons el nombre de fills i filles (PAS)

\begin{tabular}{lcccccc} 
& \multicolumn{2}{c}{ Un/a fill/a \% } & \multicolumn{2}{c}{ Dos fills/es \% } & \multicolumn{2}{c}{ Tres fills/es \% } \\
& Home & Dona & Home & Dona & Home & Dona \\
\hline $\begin{array}{l}\text { Estic en } \\
\text { desacord }\end{array}$ & 16,0 & 35,5 & 11,1 & 33,3 & 0 & 42,9 \\
Estic d'acord & 86,0 & 46,7 & 85,2 & 56,9 & 75,0 & 57,2 \\
\hline
\end{tabular}

Com s'ha vist en taules anteriors, els homes mostren un grau d'acord major que les dones si bé, en aquest cas, el grau d'acord respecte a l'equilibri és inversament proporcional al nombre de fills, és a dir, que com més fills es tenen s'incrementa, tant per a homes com per a dones, la consideració que hi ha un equilibri en el repartiment, conseqüència que és més «necessària» la participació masculina en el quefer domèstic.

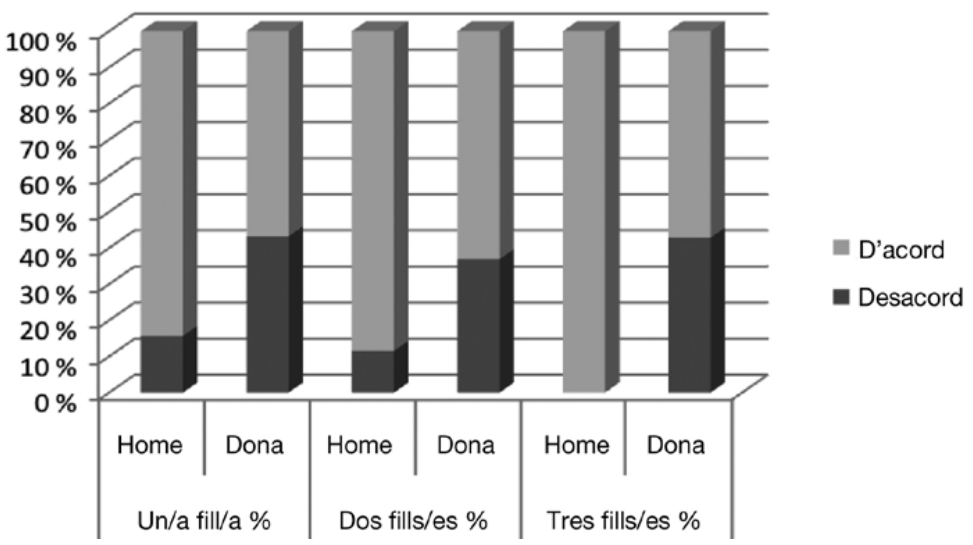

Gràfic 4.

Percepció sobre el repartiment equilibrat de tasques domèstiques segons el nombre de fills i filles (PAS) 
Taula 5.

Percepció sobre el repartiment equilibrat de l'atenció de fills i filles per nombre de fills i filles (PDI)

\begin{tabular}{lcccccc} 
& \multicolumn{2}{c}{ Un/a fill/a \% } & \multicolumn{2}{c}{ Dos fills/es \% } & \multicolumn{2}{c}{ Tres fills/es \% } \\
& Home & Dona & Home & Dona & Home & Dona \\
Estic en desacord & 10,4 & 28,6 & 18,7 & 40,5 & 33,3 & 18,2 \\
Estic d'acord & 68,8 & 57,2 & 67,5 & 52,4 & 44,4 & 63,7 \\
\hline
\end{tabular}

Hi ha menys homes del PDI que estan d'acord en el fet que el repartiment és equilibrat si ho comparem amb els homes del PAs. Les dones amb dos fills o filles incrementen en 12 punts pel que fa als que tenen només un fill o filla en què estan en desacord amb el fet que el repartiment és equilibrat, senyal que quan augmenta el nombre de criatures, augmenten també les tasques a realitzar dins de casa.

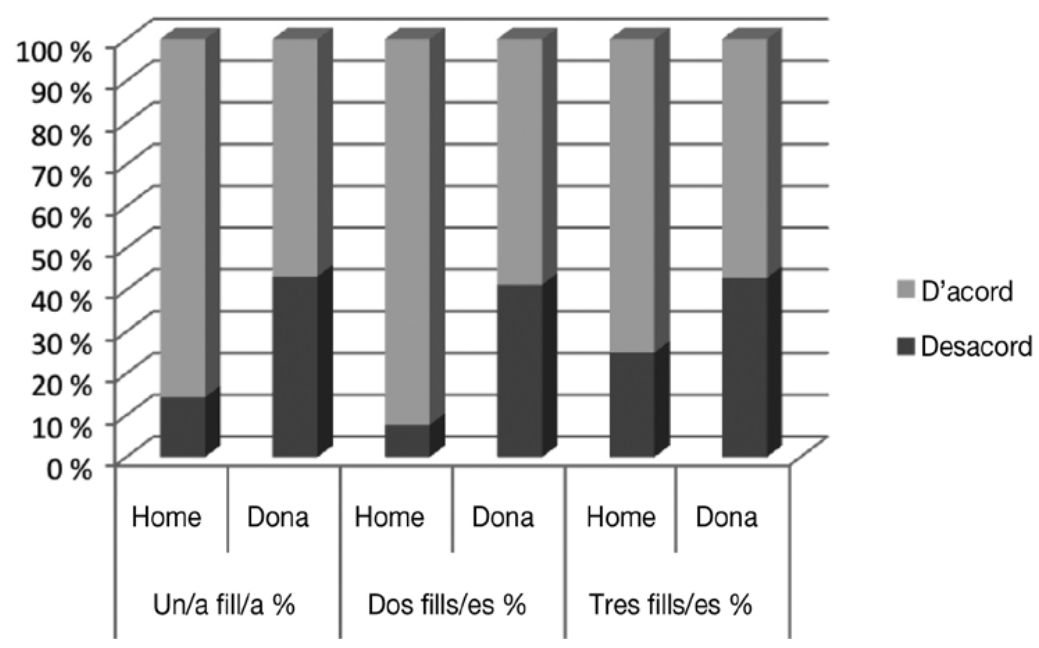

Gràfic 5 .

Percepció sobre el repartiment equilibrat de l'atenció de fills i filles per nombre de fills i filles (PDI) 
Finalment, mostrem l'encreuament d'aquesta pregunta amb la categoria laboral de les persones enquestades amb l'objectiu de mostrar la possible incidència que té aquesta variable en la percepció del repartiment equilibrat de les tasques domèstiques.

Taula 6.

Percepció sobre el repartiment equilibrat de tasques domèstiques per categoria laboral (PAS)

\section{Grup A Grup A B (\%) Grup C/ Grup C/ sense/d (\%) amb/d (\%) sense d (\%) amb d (\%)}

$\begin{array}{llllllllll}\mathbf{H} & \mathbf{M} & \mathbf{H} & \mathbf{M} & \mathbf{H} & \mathbf{M} & \mathbf{H} & \mathbf{M} & \mathbf{H} & \mathbf{M}\end{array}$

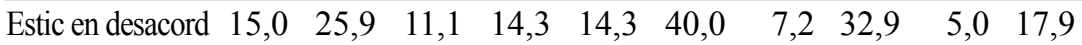
$\begin{array}{lllllllllll}\text { Estic d'acord } \quad 60,0 & 40,7 & 44,4 & 57,2 & 85,7 & 46,7 & 78,6 & 50,7 & 80,0 & 57,2\end{array}$

Les dones de totes les categories laborals mostren un nivell de desacord més elevat que els homes.

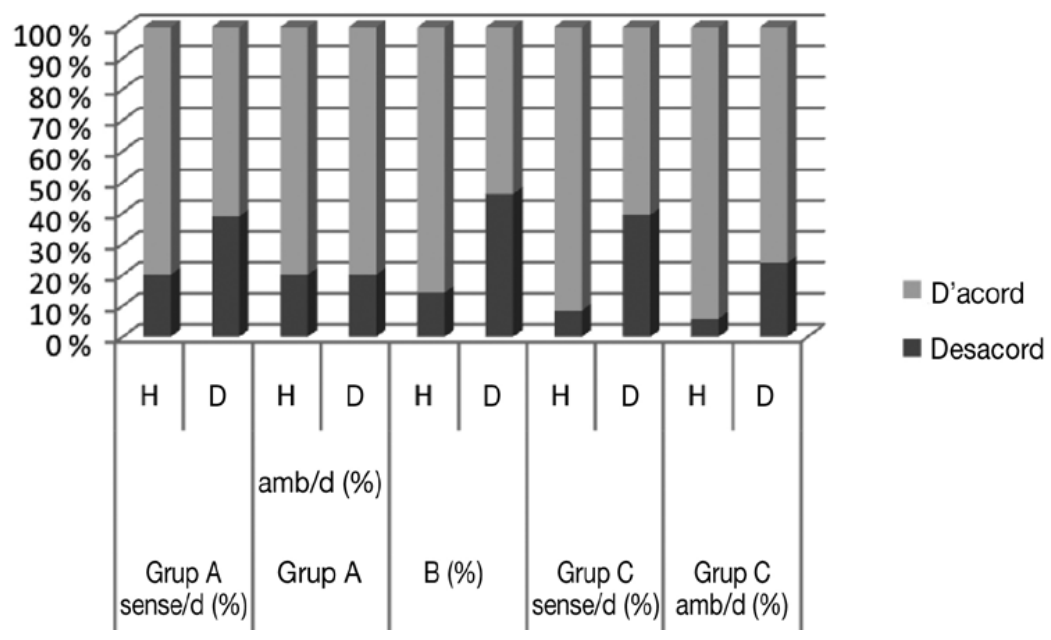

Gràfic 6.

Percepció sobre el repartiment equilibrat de tasques domèstiques per categoria laboral (PAS) 


\section{Taula 7.}

Percepció sobre el repartiment equilibrat de tasques domèstiques per categoria laboral (PDI) (\%)

\begin{tabular}{lccccccccc} 
& \multicolumn{2}{c}{$\begin{array}{c}\text { Professorat } \\
\text { funcionari }\end{array}$} & \multicolumn{2}{c}{$\begin{array}{c}\text { Personal lab. } \\
\text { indefinit }\end{array}$} & \multicolumn{2}{c}{$\begin{array}{c}\text { Professorat } \\
\text { associat }\end{array}$} & \multicolumn{2}{c}{$\begin{array}{c}\text { Personal } \\
\text { becari }\end{array}$} \\
& Homes & Dones & Homes & Dones & Homes & Dones & Homes & Dones \\
\hline $\begin{array}{l}\text { Estic en } \\
\text { desacord }\end{array}$ & 10,7 & 19,4 & 23,1 & 32,1 & 17,6 & 25,9 & 25,0 & 33,0 \\
Estic d'acord & 58,7 & 56,4 & 46,2 & 47,2 & 67,7 & 45,2 & 25,0 & 16,7 \\
\hline
\end{tabular}

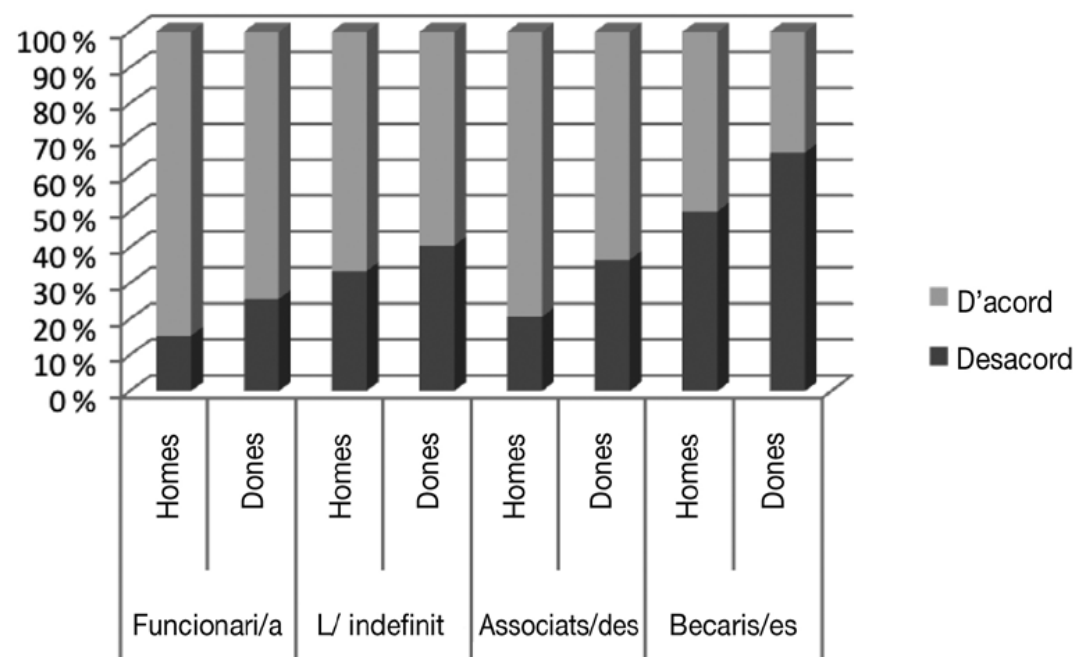

Gràfic 7.

Percepció sobre el repartiment equilibrat de tasques domèstiques per categoria laboral (PDI) $(\%)$

Per categories laborals, es mantenen les mateixes diferències entre dones i homes pel que fa al nivell de desacord més alt expressat per 
les dones quant a l'equilibri en el repartiment de les tasques domèstiques. La categoria de professorat associat és la que reflecteix una major discrepància entre dones i homes.

\subsection{EN L'ATENCIÓ A FILLS I FILLES}

Pel que fa al denominat «treball de reproducció» (Borderías, Carrasco i Alemany, 1994), les tasques domèstiques es complementen amb les tasques d'atenció d'aquells membres dependents de la família. En aquest punt ens centrem en l'atenció a criatures, ja que tal com han mostrat els resultats totals de l'enquesta, el nombre de persones que s'encarreguen de l'atenció a persones grans dependents no suposa una representativitat sobre la qual es poden traure conclusions.

Vegem en la següent taula si coincideix amb els resultats relacionats amb la realització de tasques domèstiques o es produeixen discrepàncies en l'exercici d'unes i d'altres tasques:

Taula 8.

Considere que hi ha equilibri en l'atenció a fills i filles entre la meua parella i jo

\begin{tabular}{lcccc} 
& \multicolumn{2}{c}{ PAS \% } & \multicolumn{2}{c}{ PDI \% } \\
& Homes & Dones & Homes & Dones \\
Estic d'acord & 54,3 & 36,4 & 49,0 & 37,0 \\
Estic en desacord & 8,5 & 29,2 & 12,9 & 24,7 \\
\hline
\end{tabular}




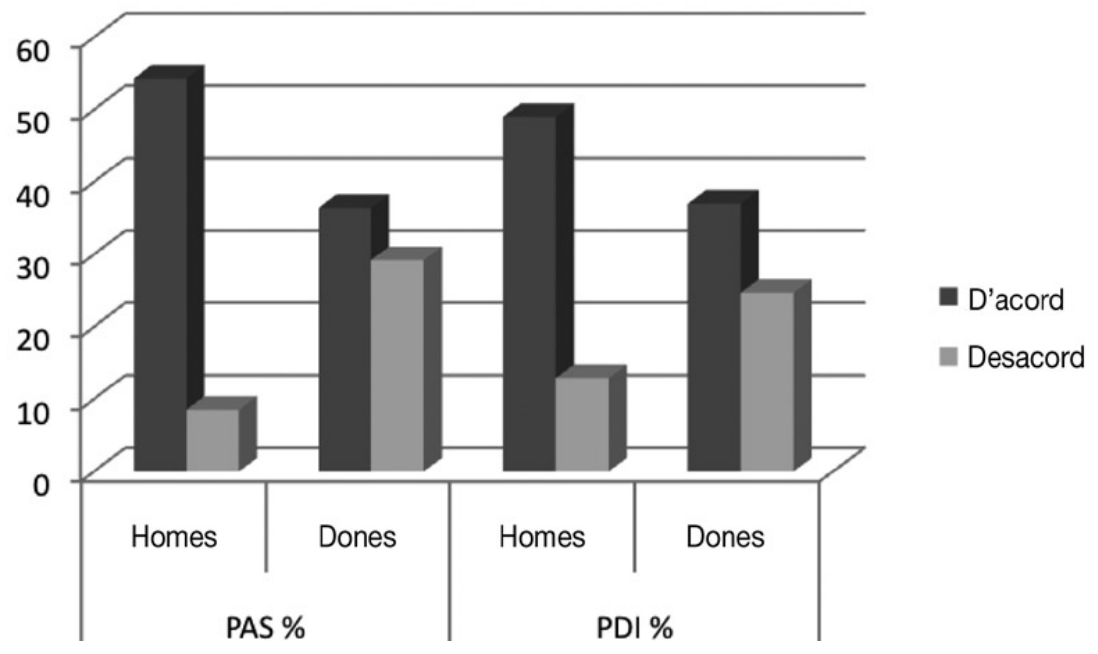

Gràfic 8.

Considere que hi ha equilibri en l'atenció a fills i filles entre la meua parella i jo

Pel que fa a l'equilibri en l'atenció a fills i filles, s'incrementa el nombre de les persones enquestades que responen «Indiferent», que se situa per al conjunt dels col·lectius en una mitjana un poc més alta del $30 \%$.

Comparant aquestes últimes dades amb les obtingudes en el punt anterior, relacionades amb les tasques domèstiques, s'observen les diferències següents: hi ha major acord en els dos col·lectius pel que fa que hi ha un equilibri en la realització de tasques domèstiques en la parella. En ambdós casos, és el col·lectiu PAs masculí el que expressa més acord, mentre que també per a ambdós casos -tasques domèstiques i atenció a criatures- són les dones del pas les que expressen més desacord en el fet que hi ha un equilibri.

En les següents taules exposarem dades sobre la dita percepció tenint en compte les característiques de les persones enquestades. 
Taula 9.

Percepció sobre el repartiment equilibrat de l'atenció a fills i filles (PAS)

\begin{tabular}{lccccccccc|} 
& \multicolumn{3}{c}{$>\mathbf{3 3}$ anys \% } & $\mathbf{3 3 - 3 9}$ anys \% & $\mathbf{4 0 - 4 9}$ anys \% & $+\mathbf{5 0}$ anys \% \\
& Home & Dona & Home & Dona & Home & Dona & Home & Dona \\
\hline Estic en desacord & 0 & 11,1 & 3,4 & 28,6 & 9,7 & 31,6 & 14,2 & 30,0 \\
Estic d'acord & 16,7 & 22,2 & 69,0 & 40,5 & 63,4 & 39,3 & 28,0 & 25,0 \\
\hline
\end{tabular}

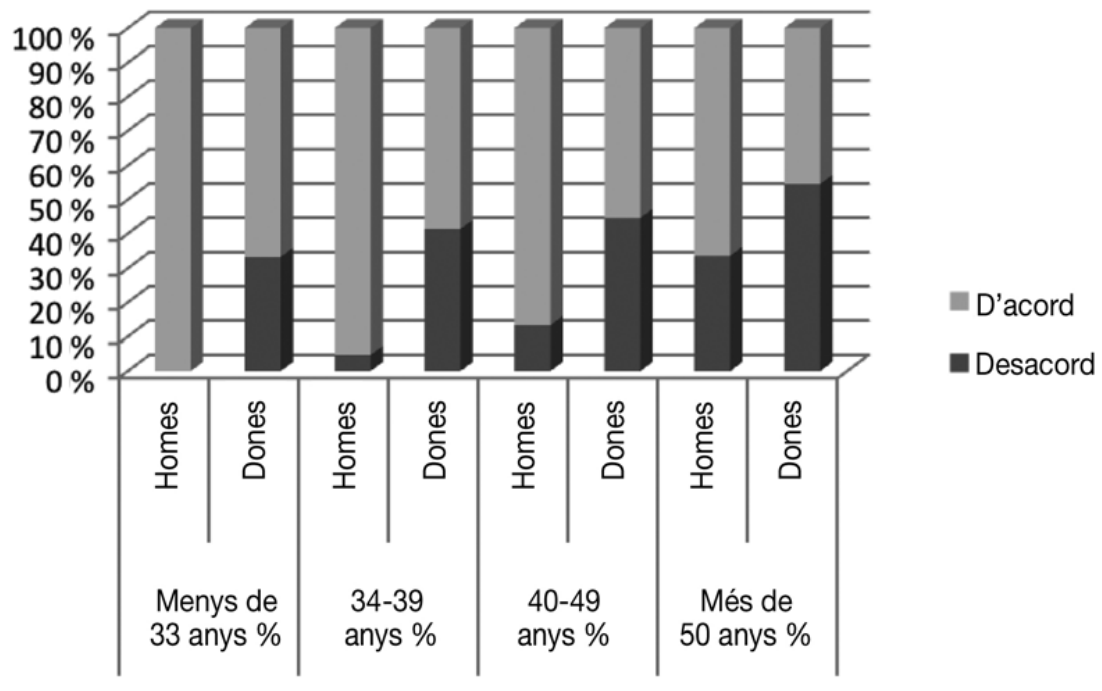

Gràfic 9.

Percepció sobre el repartiment equilibrat de l'atenció a fills i filles (PAS) 
Taula 10.

Percepció sobre el repartiment equilibrat de l'atenció a fills i filles (PDI)

\begin{tabular}{|lrrrrrrrrr} 
& \multicolumn{3}{c}{$\mathbf{3 3}$ anys \% } & \multicolumn{3}{c}{$\mathbf{3 3 - 3 9}$ anys } & \multicolumn{2}{c}{$\mathbf{4 0 - 4 9}$ anys } & \multicolumn{2}{c}{$+\mathbf{5 0}$ anys \% } \\
& Home & Dona & Home & Dona & Home & Dona & Home & Dona \\
\hline Estic en desacord & 9,1 & 25,0 & 15,6 & 33,3 & 15,0 & 23,1 & 8,4 & 5,9 \\
Estic d'acord & 18,2 & 15,0 & 43,8 & 33,3 & 56,3 & 44,9 & 50,0 & 41,1 \\
\hline
\end{tabular}

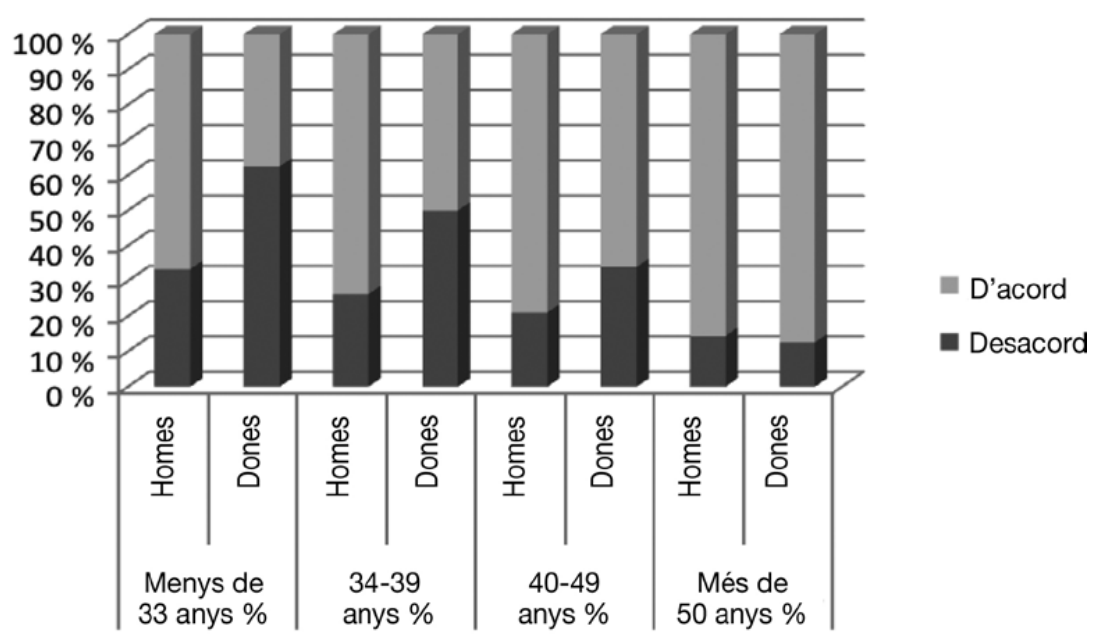

Gràfic 10 .

Percepció sobre el repartiment equilibrat de l'atenció a fills i filles (PDI)

Per a tots els grups etaris, les dones tenen una percepció de desequilibri més alta que els homes. L'excepció està en el grup d'edat de dones PDI de més de 50 anys. 
Taula 11.

Percepció sobre el repartiment equilibrat de l'atenció a fills i filles per nombre de fills i filles (PAS)

\begin{tabular}{lcccccc} 
& \multicolumn{2}{c}{ Un/a fill/a \% } & \multicolumn{2}{c}{ Dos fills/es \% } & \multicolumn{2}{c}{ Tres fills/es \% } \\
& Home & Dona & Home & Dona & Home & Dona \\
\hline Estic en desacord & 12,0 & 35,5 & 7,4 & 37,2 & 25,0 & 42,9 \\
Estic d'acord & 72,0 & 46,7 & 88,9 & 53,0 & 75,0 & 57,2 \\
\hline
\end{tabular}

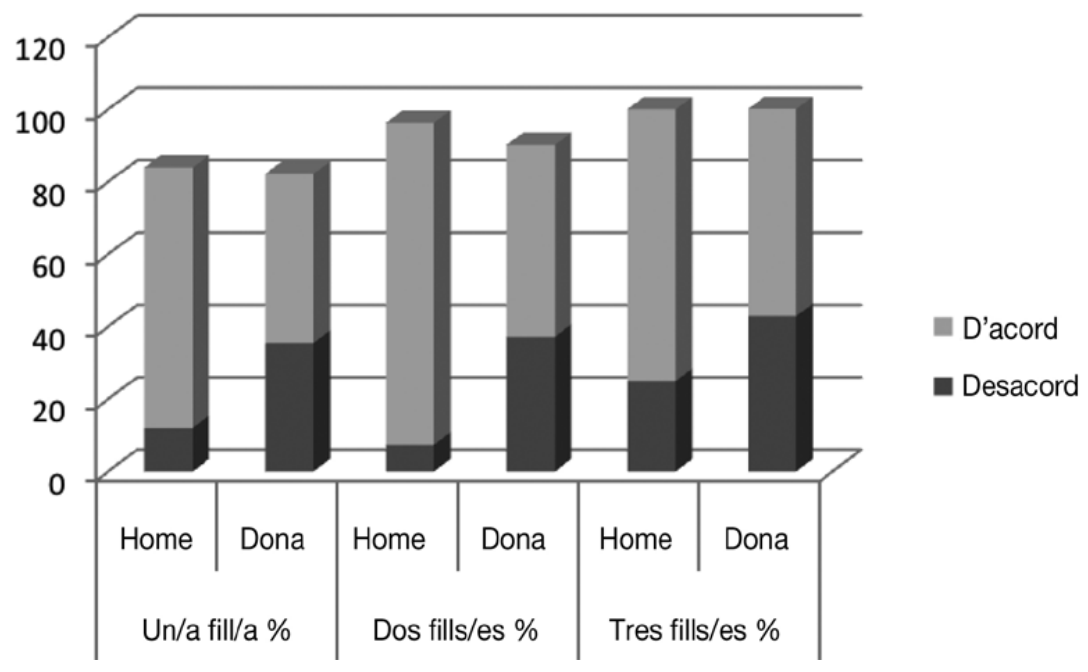

Gràfic 11.

Percepció sobre el repartiment equilibrat de l'atenció a fills i filles per nombre de fills i filles (PAS) 
Taula 12.

Percepció sobre el repartiment equilibrat de l'atenció a fills i filles per nombre de fills i filles (PDI)

\begin{tabular}{lcccccc} 
& \multicolumn{2}{c}{ Un/a fill/a \% } & \multicolumn{2}{c}{ Dos fills/es \% } & \multicolumn{2}{c}{ Tres fills/es \% } \\
& Home & Dona & Home & Dona & Home & Dona \\
\hline Estic en desacord & 16,7 & 31,4 & 18,7 & 42,9 & 22,2 & 36,4 \\
Estic d'acord & 64,6 & 54,2 & 69,8 & 52,4 & 55,5 & 45,5 \\
\hline
\end{tabular}

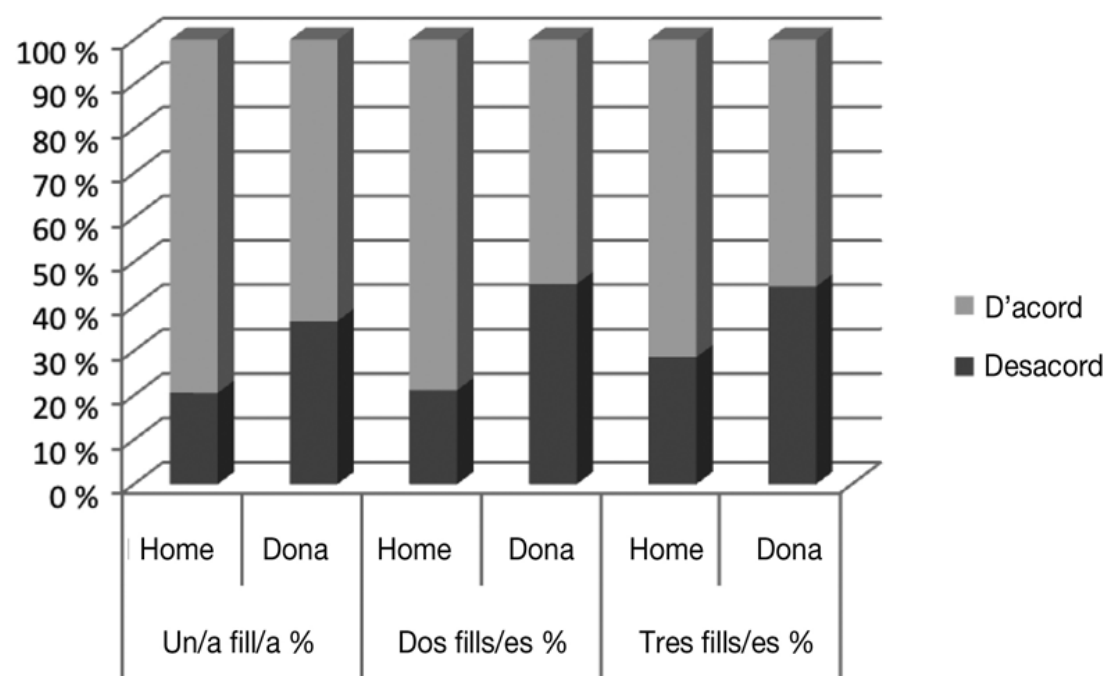

Gràfic 12.

Percepció sobre el repartiment equilibrat de l'atenció a fills i filles per nombre de fills i filles (PDI)

Dos aspectes es conclouen amb claredat: en primer lloc, el conjunt de dones, tant del PDI com del PAs, mostra desacord amb l'afirmació 
que hi ha un equilibri pel que fa a l'atenció a fills i filles i, en segon lloc, com més alt és el nombre de fills i filles, el desacord és més alt també.

Ara bé, les dones del PAs amb tres fills o filles superen en 6 punts percentuals les dones del PDI en el seu nivell de desacord, si bé en aquestes últimes el nombre de respostes «Indiferent» és superior.

Pel que fa als homes, el PAs masculí supera els homes del PDI en la seua consideració d'estar d'acord amb l'existència d'un equilibri, contrastant, doncs, amb les respostes donades per les dones PAs, que manifesten estar més en desacord amb aquesta opinió.

Taula 13.

Percepció sobre el repartiment equilibrat de l'atenció a fills i filles per categoria laboral (PAS)

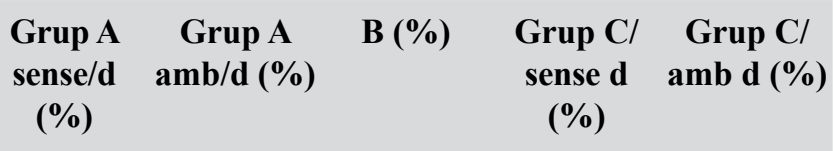

$\begin{array}{llllllllll}\text { H } & \text { D } & \text { H } & \text { D } & \text { H } & \text { D } & \text { H } & \text { D } & \text { H } & \text { D }\end{array}$

Estic en desacord

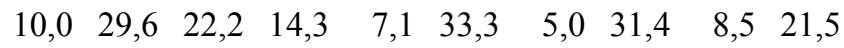

Estic d'acord

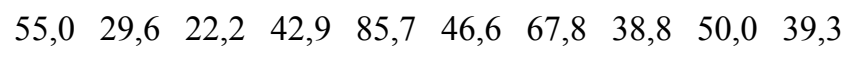




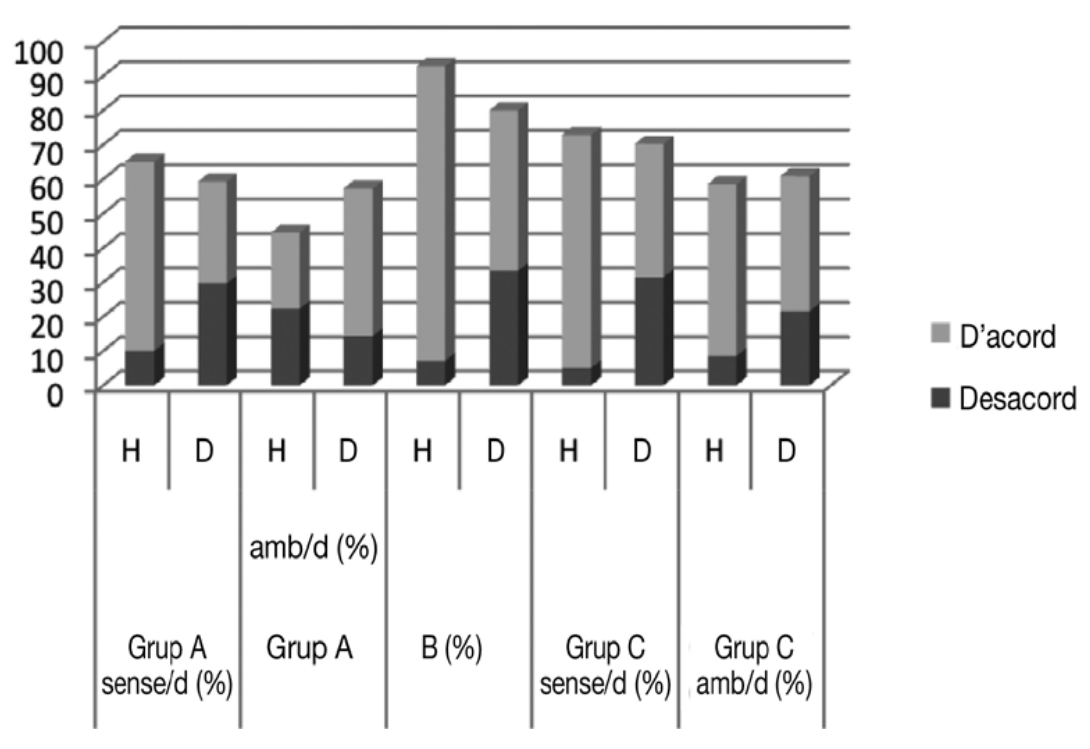

Gràfic 13.

Percepció sobre el repartiment equilibrat de l'atenció a fills i filles per categoria laboral (PAS)

Si bé en termes generals l'acord és superior amb escreix al desacord, són sobretot els homes, amb aclaparadora majoria i per a totes les categories laborals, els que pareixen percebre que hi ha un equilibri entre ells i les seues parelles pel que fa a l'atenció a fills i filles. 


\section{Taula 14.}

Percepció sobre el repartiment equilibrat de l'atenció a fills i filles (PDI) (\%)

\begin{tabular}{lccccccccc} 
& \multicolumn{2}{c}{$\begin{array}{c}\text { Professorat } \\
\text { funcionari }\end{array}$} & \multicolumn{2}{c}{$\begin{array}{c}\text { Personal } \\
\text { laboral }\end{array}$} & \multicolumn{2}{c}{$\begin{array}{c}\text { Professorat } \\
\text { associat }\end{array}$} & \multicolumn{2}{c}{$\begin{array}{c}\text { Personal } \\
\text { becari }\end{array}$} \\
& Homes & Dones & Homes & Dones & Homes & Dones & Homes & Dones \\
Estic en & 9,7 & 20,9 & 18,0 & 32,1 & 11,8 & 22,6 & 25,0 & 0,0 \\
desacord & & & & & & & & \\
Estic d'acord & 54,7 & 48,4 & 28,2 & 32,1 & 67,6 & 29,1 & 25,0 & 16,7 \\
\hline
\end{tabular}

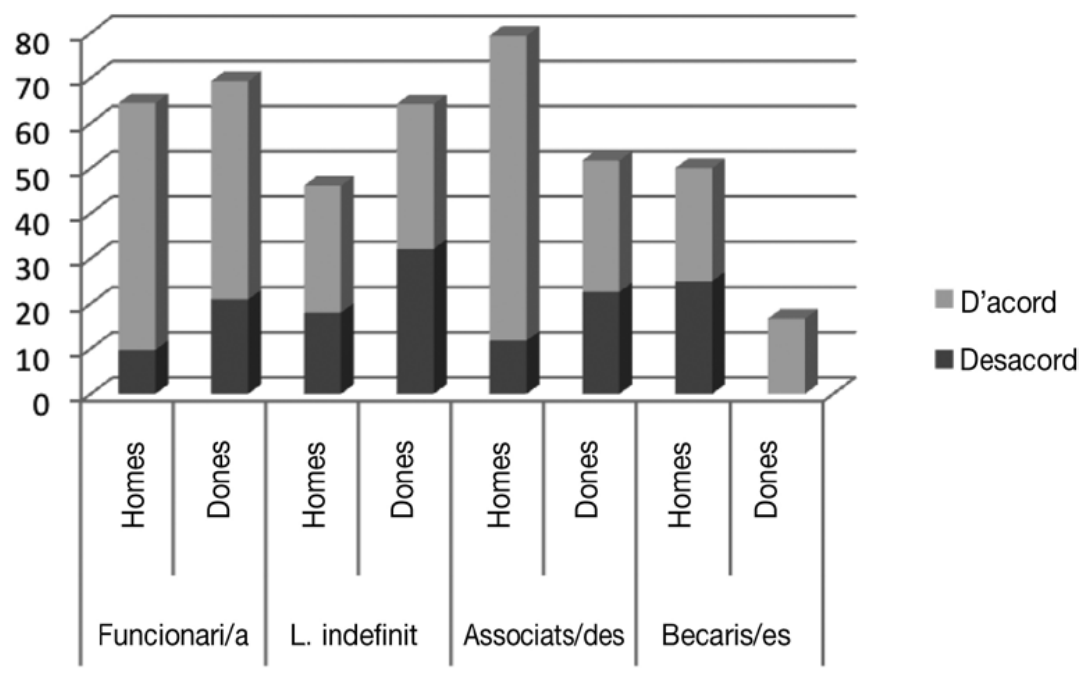

Gràfic 14.

Percepció sobre el repartiment equilibrat de l'atenció a fills i filles (PDI) (\%) 


\subsection{ENTRE LES NECESSITATS PERSONALS, FAMILIARS I LABORALS}

La següent pregunta plantejava si les persones enquestades consideren el repartiment entre la seua vida laboral, familiar i personal equilibrat. El temps dedicat a les necessitats personals ens indica el temps disponible que cada persona té per a si mateixa fora dels temps de treball, siga aquest laboral o domèstic i d'atenció.

Taula 15.

Considere que hi ha equilibri entre les meues necessitats personals, familiars i laborals (PAS i PDI)

\begin{tabular}{lcccc} 
& \multicolumn{2}{c}{ PAS \% } & \multicolumn{2}{c}{ PDI \% } \\
& Homes & Dones & Homes & Dones \\
Estic d'acord & 61,7 & 28,5 & 40,5 & 27,9 \\
Estic en desacord & 12,7 & 45,8 & 29,4 & 42,8 \\
\hline
\end{tabular}

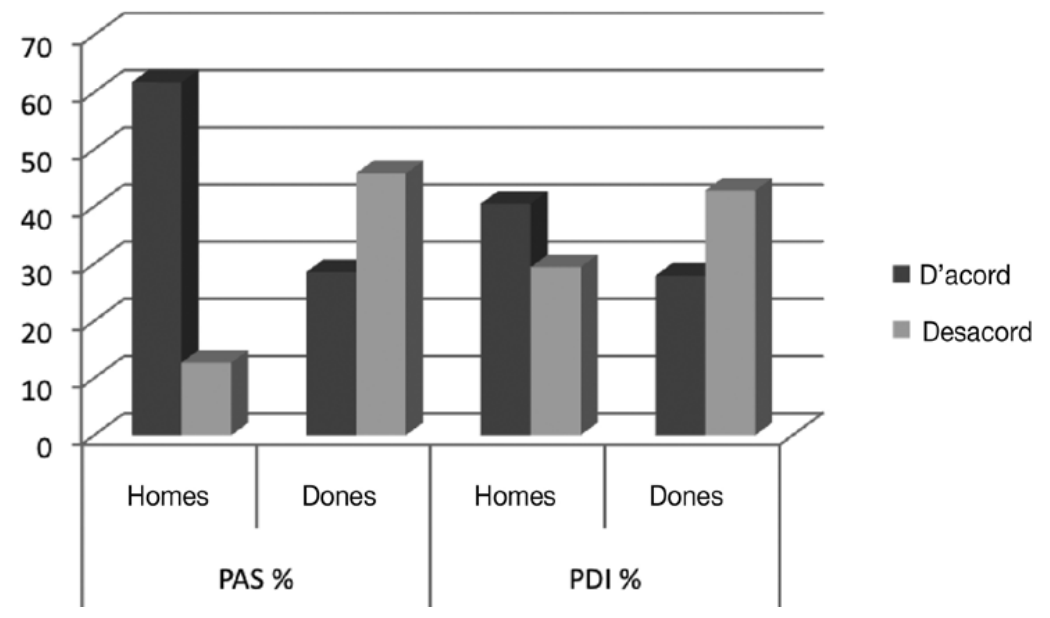

Gràfic 15.

Considere que hi ha equilibri entre les meues necessitats personals, familiars i laborals (PAS i PDI) 
Aquesta taula és molt significativa quant a les respostes obtingudes: en primer lloc, es constata una vegada més el nombre més alt de respostes que estan d'acord amb l'existència d'un equilibri pel que fa a la vida personal, laboral i familiar en els homes, tant del PDI com del PAs. Ara bé, la distància entre ambdós col·lectius d'homes és de 20 punts percentuals, és a dir, que els homes del Pas responen en major proporció que els homes del PDI estar d'acord que hi ha un equilibri.

En segon lloc, i pel que fa a les dones dels dos col-lectius contemplats, estan totes més en desacord que d'acord en la percepció que la seua vida personal està equilibrada en el que afecta la seua vida laboral, familiar i personal. A més, presenten poques diferències entre elles, fet que contrasta amb el que s'ha manifestat per als homes.

Vegem a continuació si es presenten contrastos en els dos collectius en considerar les variables següents: l'edat, el nombre de fills i filles i les categories professionals en relació al repartiment equilibrat de les necessitats personals, familiars i laborals.

Iniciem l'exposició amb el referent a l'edat per al PAs, referint-nos a continuació al PDI.

Taula 16.

Percepció personal sobre el repartiment equilibrat de necessitats personals, familiars i laborals (PAS) (\%)

\begin{tabular}{lccccccccc} 
& $\begin{array}{c}\text { Menys de 33 } \\
\text { anys }\end{array}$ & $\mathbf{3 4 - 3 9}$ anys & 40-49 anys & \multicolumn{2}{c}{$\begin{array}{c}\text { Més de 50 } \\
\text { anys }\end{array}$} \\
& Homes & Dones & Homes & Dones & Homes & Dones & Homes & Dones \\
\hline Estic en desacord & 0 & 11,1 & 6,9 & 54,7 & 21,9 & 49,3 & 7,1 & 40,0 \\
Estic d'acord & 83,3 & 33,3 & 68,9 & 26,2 & 60,9 & 30,4 & 50,0 & 25,0 \\
\hline
\end{tabular}




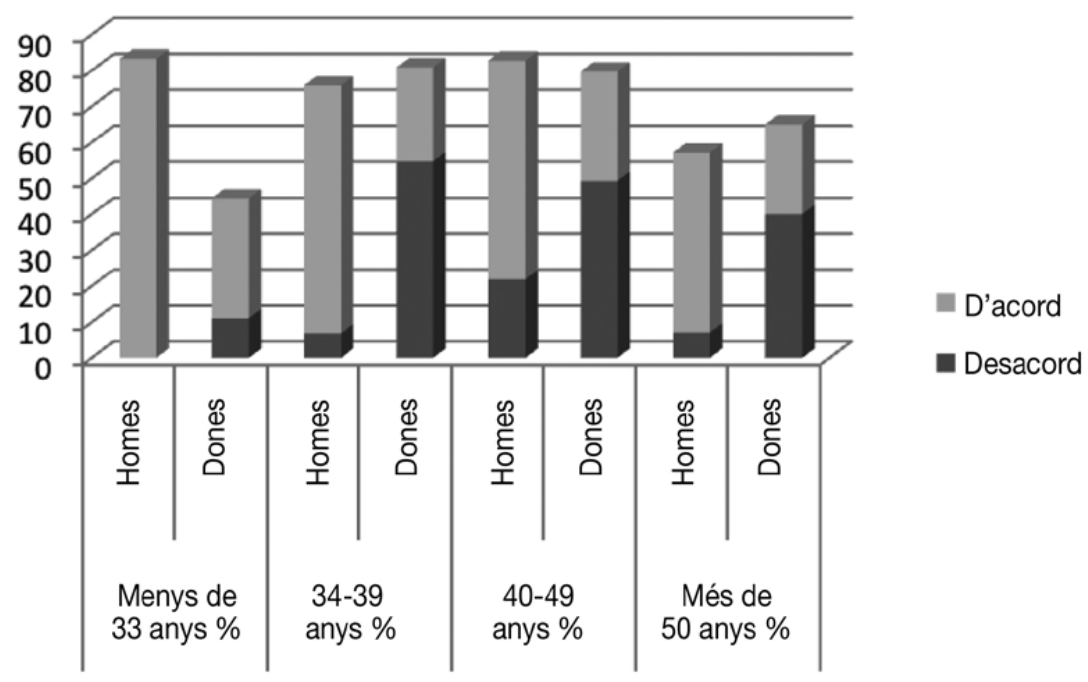

Gràfic 16.

Percepció personal sobre el repartiment equilibrat de necessitats personals, familiars i laborals (PAS) $(\%)$

Taula 17.

Percepció personal sobre el repartiment equilibrat de necessitats personals, familiars i laborals (PDI) $(\%)$
Menys de 33 34- 39 anys 40-49 anys Més de 50 anys anys

Homes Dones Homes Dones Homes Dones Homes Dones

Estic en desacord $9,1 \quad 25,0 \quad 31,2 \quad 52,1 \quad 36,3 \quad 42,0 \quad 19,4 \quad 41,1$ $\begin{array}{llllllll}\text { Estic d'acord } \quad 27,3 & 40,0 & 50,0 & 25,1 & 37,5 & 27,5 & 47,2 & 23,5\end{array}$ 


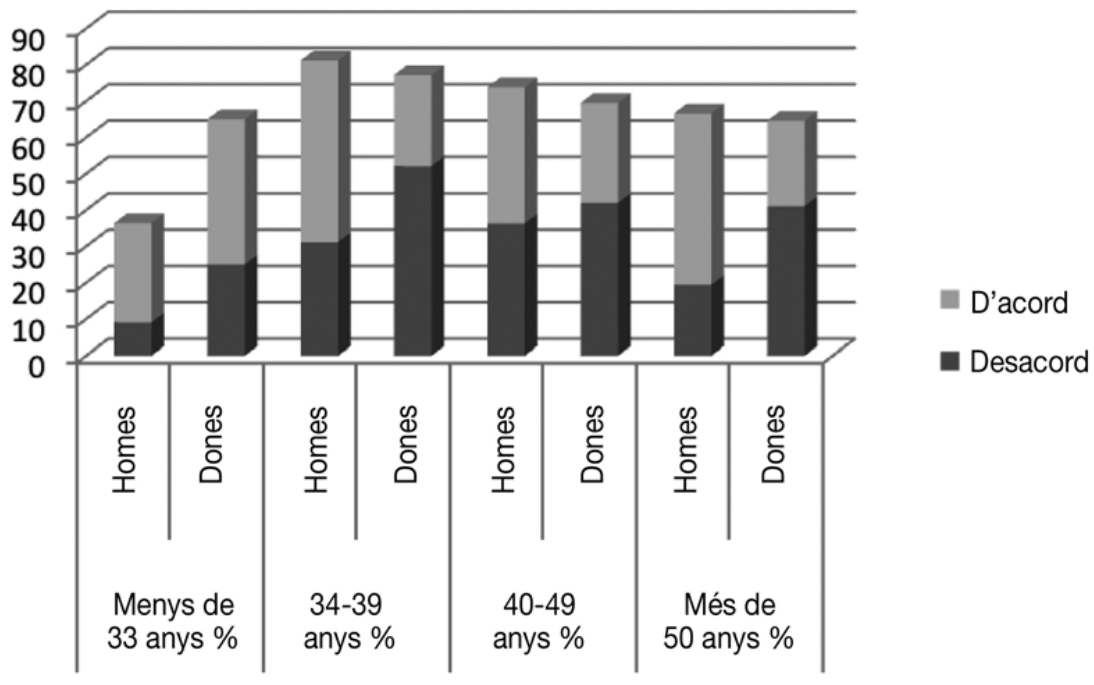

Gràfic 17.

Percepció personal sobre el repartiment equilibrat de necessitats personals, familiars i laborals (PDI) $(\%)$

Seguint la mateixa tendència dels resultats assenyalats en paràgrafs anteriors, les dones mostren un grau de desacord més alt que els homes per als dos col·lectius contemplats, mentre que els homes responen en un nombre més alt estar-hi d'acord.

Ara bé, les dones dels distints grups d'edat manifesten resultats diferents: les dones d'edat compresa entre els 34-39 anys són les que en una proporció de més del $50 \%$ responen estar-hi en desacord: això és lògic perquè és en aquest grup d'edat on amb més freqüència s'és mare.

En els dos grups següents en edat, si bé l'expressió de desacord descendeix, es manté en respostes altes si les contrastem amb les donades per les dones del grup de menys de 30 anys. Clar indici 
que, com assenyalava M. Jesús Izquierdo (1995) «Ser casada (o vivint en parella) és estar ocupada domèsticament», és a dir, que el fet de viure en parella ja pressuposa per a les dones tenir una altra ocupació.

Respecte dels homes, els més joves del PAs són els que estan més d'acord a considerar que la seua vida està equilibrada $(83,3 \%)$; si bé aquest percentatge va descendint a mesura que s'incrementa l'edat; així el grup de més de 51 anys queda en un percentatge del $50 \%$, motivat segurament per la seua major implicació en les tasques domèstiques i d'atenció, així com en un major compromís professional.

L'edat es relaciona directament amb el nombre de fills i filles. Vegem a continuació, per a aquelles persones que tenen descendència, com afecta el nombre de fills o filles en la percepció sobre si hi ha un equilibri entre les seues necessitats personals, laborals i familiars.

Taula 18.

Percepció sobre el repartiment equilibrat de les necessitats personals, familiars i laborals per nombre de fills i filles (PAS)

\begin{tabular}{lcccccc} 
& \multicolumn{2}{c}{ Un/a fill/a \% } & \multicolumn{2}{c}{ Dos fills/es \% } & \multicolumn{2}{c}{ Tres fills/es \% } \\
& Home & Dona & Home & Dona & Home & Dona \\
\hline $\begin{array}{l}\text { Estic en } \\
\text { desacord }\end{array}$ & 20,0 & 48,9 & 11,1 & 58,8 & 25,0 & 85,7 \\
Estic d'acord & 72,0 & 28,9 & 70,3 & 29,4 & 0 & 75,0 \\
\hline
\end{tabular}




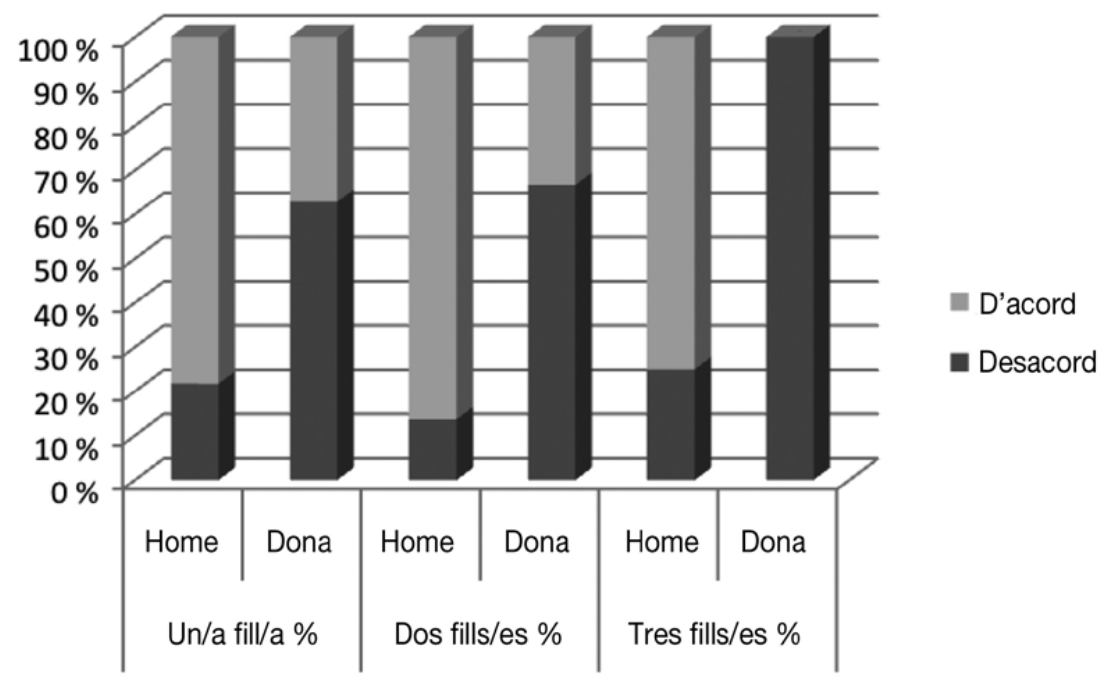

Gràfic 18.

Percepció sobre el repartiment equilibrat de les necessitats personals, familiars i laborals per nombre de fills i filles (PAS)

Taula 19.

Percepció sobre el repartiment equilibrat de les necessitats personals, familiars i laborals per nombre de fills i filles (PDI)

\begin{tabular}{lcccccc} 
& \multicolumn{2}{c}{ Un/a fill/a \% } & \multicolumn{2}{c}{ Dos fills/es \% } & \multicolumn{2}{c}{ Tres fills/es \% } \\
& Home & Dona & Home & Dona & Home & Dona \\
\hline $\begin{array}{l}\text { Estic en } \\
\text { desacord }\end{array}$ & 29,2 & 40,0 & 37,2 & 61,9 & 44,4 & 36,4 \\
Estic d'acord & 45,8 & 45,7 & 51,1 & 21,5 & 22,2 & 36,4 \\
\hline
\end{tabular}




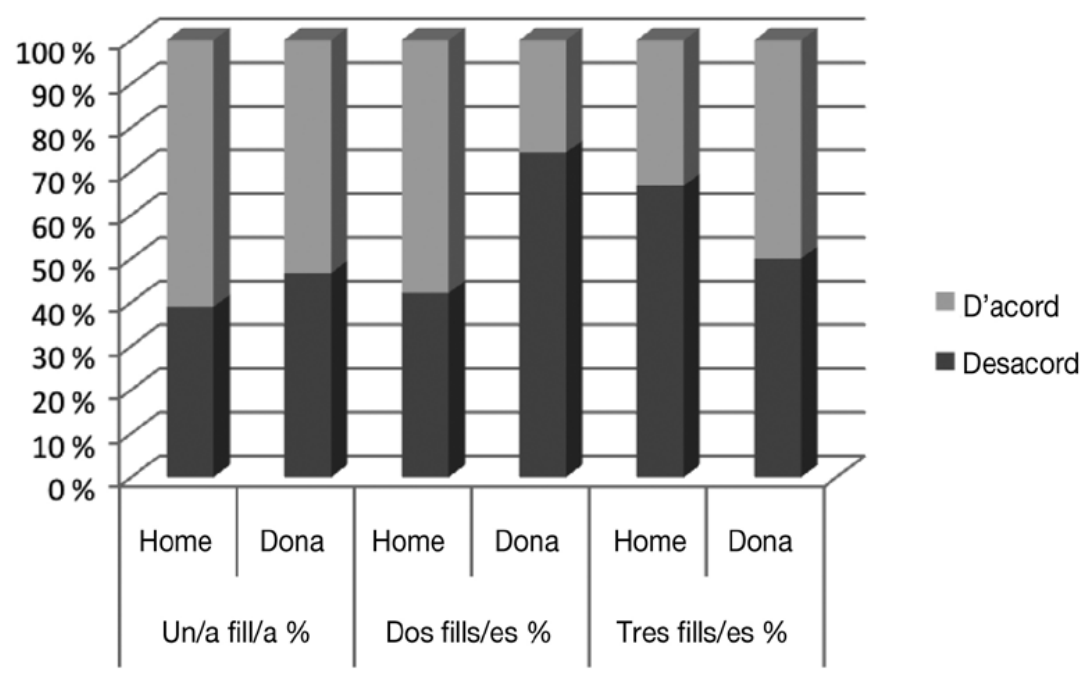

Gràfic 19.

Percepció sobre el repartiment equilibrat de les necessitats personals, familiars i laborals per nombre de fills i filles (PDI)

Les dones del PAs incrementen el seu percentatge de desacord com més fills i filles tenen; així, la xifra arriba al 85,7 \% de les enquestades amb tres criatures que mostren el seu desacord en la consideració que en la seua vida hi ha un equilibri entre la seua vida laboral, personal i familiar.

Les dones del PDI, amb un nivell de respostes del $10 \%$ en la resposta «Indiferent», incrementen el seu desacord respecte a l'equilibri entre les que tenen un fill o filla i les que en tenen dos. El nombre de dones PDI amb tres fills o filles és baix, per això les respostes no poden considerar-se representatives.

Respecte als homes del PAS, continuen estant majoritàriament d'acord en la consideració que la seua vida és equilibrada sense variar molt el percentatge de les respostes en encreuar-les amb el nombre de 
fills i filles. Contrasta, doncs, aquest resultat amb el de les seues companyes del PAS que manifesten clarament no percebre un repartiment equilibrat entre les distintes facetes de la seua vida.

Els homes del PDI es distancien en els percentatges del PAS respecte a la consideració que hi ha un equilibri en la seua vida, percentatge que arriba a ser de més de 50 punts percentuals en el cas dels homes del PDI amb tres criatures, si bé, i com hem dit amb anterioritat, la mostra incloïa poques respostes de persones amb tres descendents.

Segons pareix, i per a tots els grups d'edat i de nombre de fills i filles, les dones, tant del PAS com del PDI, mostren una percepció menor en la consideració que en la seua vida hi ha un equilibri entre els distints àmbits.

Respecte dels homes, s'observen diferències importants entre els homes del PAS i del PDI: els primers manifesten una major percepció que la seua vida és equilibrada mentre que els segons no pareixen percebre en la mateixa proporció que els homes del PAs el dit equilibri en el repartiment de la seua vida laboral, familiar i personal.

Per a concloure, analitzarem com afecta en el repartiment equilibrat de les dites facetes de la vida la categoria laboral.

Taula 20.

Percepció sobre el repartiment equilibrat de les necessitats personals, familiars i laborals per categoria laboral (PAS)
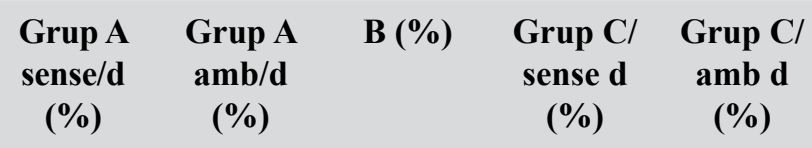
H
D H D
H D H
D H D

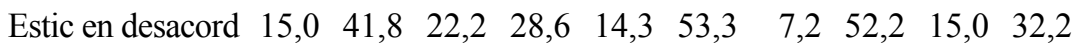

$\begin{array}{llllllllll}\text { Estic d'acord } \quad 60,0 & 14,8 & 55,5 & 42,9 & 85,7 & 33,4 & 42,1 & 26,8 & 60,0 & 42,8\end{array}$




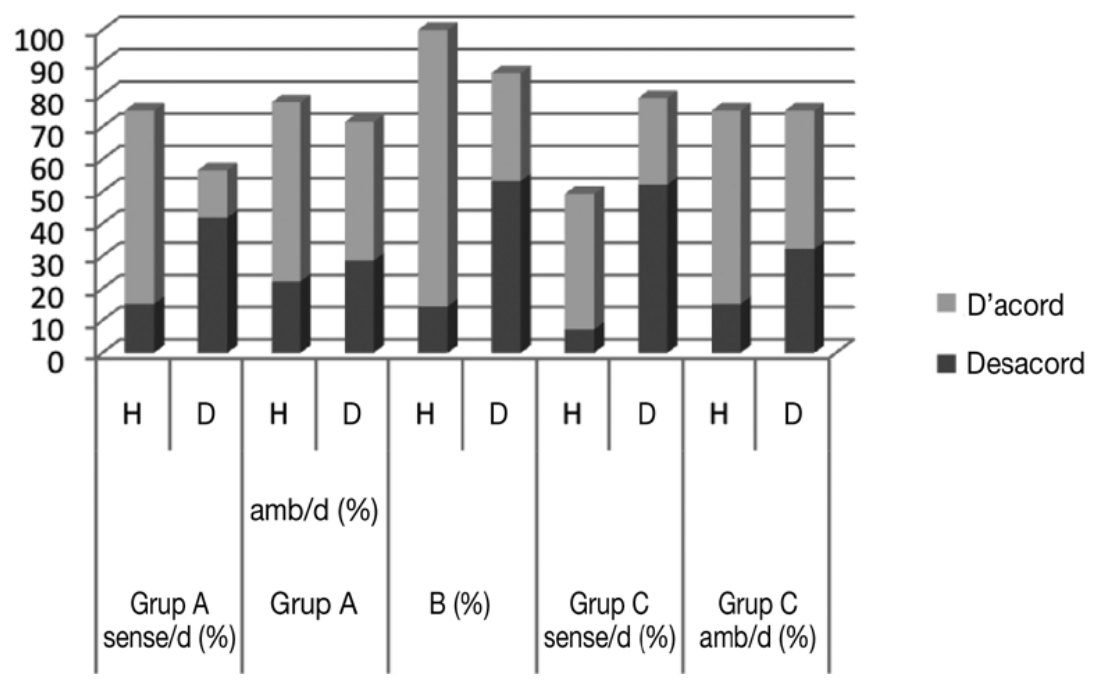

Gràfic 20.

Percepció sobre el repartiment equilibrat de les necessitats personals, familiars i laborals per categoria laboral (PAS)

Taula 21.

Percepció personal sobre el repartiment equilibrat de les necessitats personals, familiars i laborals per categoria laboral (PDI) (\%)

\begin{tabular}{lcccccccc} 
& \multicolumn{2}{c}{$\begin{array}{c}\text { Professorat } \\
\text { funcionari }\end{array}$} & \multicolumn{2}{c}{$\begin{array}{c}\text { Personal } \\
\text { laboral }\end{array}$} & \multicolumn{2}{c}{$\begin{array}{c}\text { Professorat } \\
\text { associat }\end{array}$} & \multicolumn{2}{c}{$\begin{array}{c}\text { Personal } \\
\text { becari }\end{array}$} \\
& Homes & Dones & Homes & Dones & Homes & Dones & Homes & Dones \\
\hline $\begin{array}{l}\text { Estic } \\
\text { en desacord }\end{array}$ & 29,3 & 40,4 & 30,8 & 45,3 & 29,4 & 38,4 & 25,0 & 16,7 \\
$\begin{array}{l}\text { Estic } \\
\text { d'acord }\end{array}$ & 40,0 & 30,7 & 35,9 & 32,0 & 55,9 & 16,1 & 25,0 & 33,3 \\
\hline
\end{tabular}




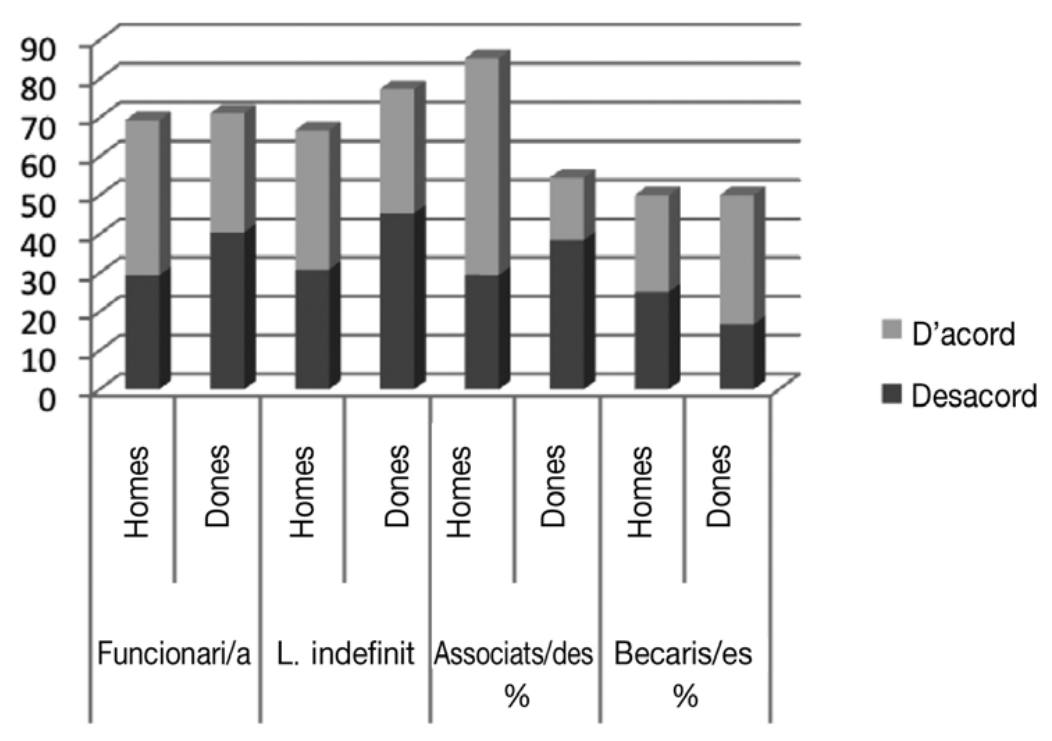

Gràfic 21 .

Percepció personal sobre el repartiment equilibrat de les necessitats personals, familiars i laborals per categoria laboral (PDI) (\%)

Les dones del PDI que més desacord mostren són les contractades laborals, seguides de les funcionàries. ${ }^{75}$ Són aquelles figures acadèmiques que tenen més exigències respecte a la carrera professional, i ocorre el mateix amb el personal becari encara que, en aquest últim cas, en ser poc representativa en la mostra no permet arribar a conclusions generalitzables.

Els professors associats són els que responen en una menor proporció que la resta de categories que hi ha un repartiment equilibrat entre els distints àmbits de la seua vida. Contràriament, són les pro-

75. En aquesta pregunta el $50 \%$ de funcionàries no contesten. 
fessores associades les que en menor proporció, un 16,6 \%, consideren que la seua vida està equilibrada.

\subsection{CONCLUSIONS}

En aquest punt hem presentat la percepció que tenen les persones enquestades respecte a la seua percepció sobre si hi ha un equilibri entre la seua vida laboral, personal i familiar així com la seua percepció sobre si és equilibrat el repartiment de les tasques domèstiques i d'atenció entre la seua parella i ella.

Si bé l'índex de no respostes ha sigut alt, les dades obtingudes ens permeten concloure el següent: les dones, tant del PAS com del PDI, manifesten una continuitat en les respostes relacionades amb l'existència d'un repartiment equilibrat entre la seua vida laboral, personal i familiar.

Aquest desacord s'aguditza en aquelles dones amb edats compreses entre els 30 i els 50 anys i amb nombre més elevat de fills i filles. Clar senyal que en les edats en què s'exigeix més atenció i cures dels descendents, el grau d'implicació és més alt pel que fa a les dites necessitats per la qual cosa l'equilibri entre els diversos àmbits resulta més costós.

Els homes treballadors de la Universitat Jaume I presenten comportaments que no són tan semblants al presentat per les dones. Els homes del pas estan molt més d'acord en la seua percepció que la seua vida és equilibrada si comparem aquesta resposta amb els seus companys del PDI.

Respecte a la percepció de la coresponsabilitat, en relació a l'existència d'un equilibri en la parella en l'execució de les tasques domèstiques i d'atenció, les dades manifesten que, si bé els homes participen en la seua realització encara queda lluny que hi haja un repartiment igualitari de les tasques; fet que indica l'exercici de la «doble jornada» per part de les dones i la seua repercussió en el món laboral. 


\section{COMPLICACIÓ PER A CONCILIAR LA VIDA LABORAL I LA VIDA FAMILIAR EN EL PERSONAL DE L'UJI}

Com hem exposat en un capítol anterior, l'articulació entre els temps dedicats a la vida laboral i a la vida familiar s'ha convertit en un tema rellevant en l'actualitat, motivat, d'una banda, per la centralitat que l'activitat laboral té en la vida de les persones en l'actual entorn econòmic competitiu i global i, d'una altra, per la transformació del sistema de gènere, que ha modificat la divisió anterior basada en l'estricta assignació de rols i espais segons el gènere.

En l'actualitat, la desconstrucció del rígid sistema de gèneres anterior, ${ }^{76}$ motivat en part per la incorporació de les dones al mercat laboral, ha complicat la realització de les tasques domèstiques $i$ d'atenció que anteriorment realitzaven de manera exclusiva les dones, exigint-hi, d'altra banda, la participació dels homes, procés que segons indiquen les distintes enquestes realitzades (enquesta Usos del tiempo, 2003 i 2010), està resultant bastant més costós que l'anterior a pesar de les distintes polítiques i campanyes implementades amb l'objectiu d'aconseguir una coresponsabilitat en les tasques domèstiques i d'atenció.

L'exercici del nou rol de «treballadora» juntament amb la continuïtat de l'exercici de l'anterior -les tasques domèstiques i d'atenció- va portar que algunes autores (Balbo, 1994 Durán, 1986; Friedan, 1983) encunyaren com a «doble jornada» $\mathrm{o}$ «presència» les activitats exercides per les dones.

Ara bé, aquest fet social no afecta totes les dones per igual, sinó que es relaciona directament amb altres variables estructurals com són: la jornada laboral, la possibilitat de promoció, el nombre de fills i filles, l'edat, la categoria laboral i la jornada laboral de la parella.

D'altra banda, amb la incorporació laboral femenina, els homes s'han vist més implicats en l'exercici d'activitats de què anteriorment estaven exclosos per qüestió de gènere. També, doncs, ells es veuen

76. Sense arribar a ser igualitari l'actual. 
afectats pel reajustament de rols i conseqüentment per l'organització dels temps.

En aquest punt exposarem l'opinió que té el personal de l'Uu sobre el grau de complicació per a conciliar la vida personal i laboral. Incloem en la taula següent les respostes del PDI i del PAs per sexe.

Taula 1.

Grau de complicació per a conciliar la vida laboral i familiar (\%)

\begin{tabular}{lcccc} 
& \multicolumn{2}{c}{ PAS } & \multicolumn{2}{c}{ PDI } \\
& Homes & Dones & Homes & Dones \\
$\begin{array}{l}\text { Complicat } \\
\text { o molt } \\
\text { complicat }\end{array}$ & 36,2 & 55,9 & 43,0 & 56,5 \\
$\begin{array}{l}\text { Senzill o } \\
\text { molt }\end{array}$ & 50,0 & 36,6 & 49,7 & 35,0 \\
senzill & & & & \\
$\begin{array}{l}\text { No ho sap/ } \\
\text { No contesta }\end{array}$ & 13,8 & 4,5 & 7,4 & 8,4 \\
\hline
\end{tabular}

El gràfic següent reflecteix amb més claredat el diferent grau de complicació per sexe. 


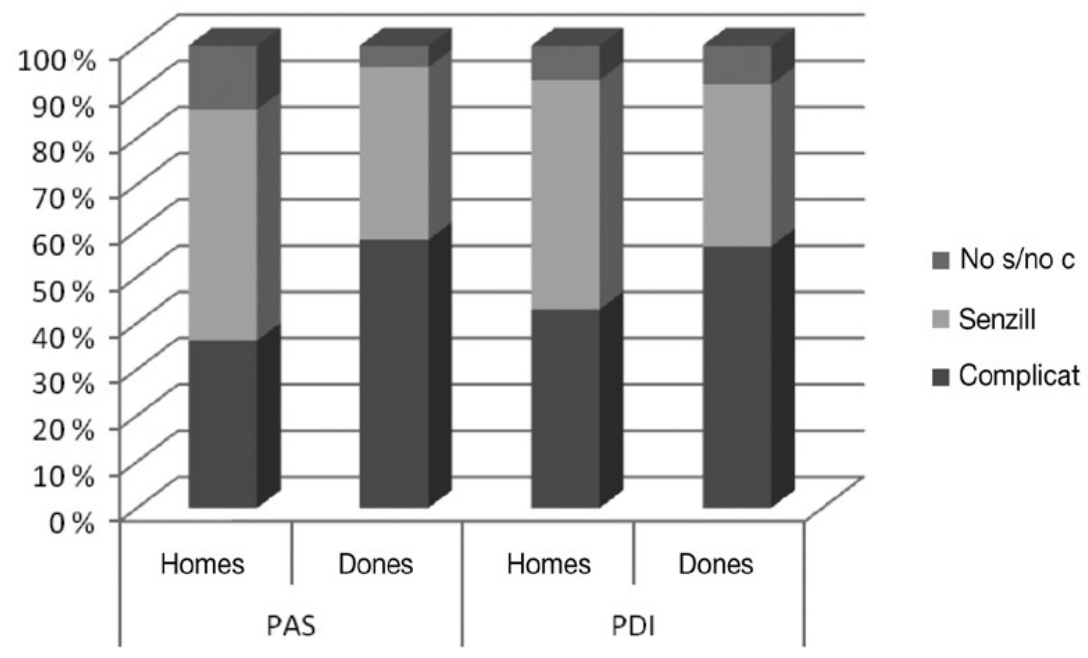

Gràfic 1 .

Grau de complicació per a conciliar la vida laboral i familiar (\%)

Les dades mostren la similitud en les respostes entre les de les dones del PAs i del PDI: en ambdós casos un $50 \%$ de les dones entrevistades consideren que els resulta complicat compatibilitzar la vida laboral amb la familiar.

Ara bé, les diferències entre dones i homes en les dues categories laborals difereixen: per al PDI, el grau de complicació per a les dones és 13,5 punts més que per als homes, mentre que per al PAs, les dones ho veuen més complicat, i les seues respostes se situen en 19,7 punts percentuals més.

És a dir, i segons mostren les dades, la conciliació pareix més complicada per als homes del PDI que per als del PAS a la nostra Universitat.

Respecte a les respostes de «No ho sap/No contesta» (NS/NC), s'observa una diferència notable entre els homes i les dones del PAs; al 
contrari, en el nombre de respostes de NS/NC en el PDI, són les dones les que superen lleugerament els homes.

En aquesta primera taula es constata la diferent opinió que dones i homes del personal de la Universitat té respecte a la conciliació dels seus temps reflectint la major o menor assumpció de les tasques domèstiques i d'atenció en els seus temps, tenint en compte que el conjunt del personal exerceix tasques laborals fora de casa.

Ara bé, i com hem assenyalat més amunt, volem conèixer com afecten les distintes variables estructurals al fet de conciliar la vida laboral i la familiar.

\subsection{COMPLICACIÓ PER A CONCILIAR SEGONS CATEGORIA LABORAL}

Iniciem l'exposició amb la categoria laboral: per a això, hem agrupat la categoria laboral del PDI en quatre grups: funcionaris (catedràtics i catedràtiques i professorat titular d'universitat i d'escola), laborals (professorat contractat, ajudants i ajudantes col-laboradors), professorat associat i personal becari. Considerem que aquestes quatre categories agrupen els diversos tipus de professorat i la seua particular situació contractual.

Per al PAs, la distribució és la següent: grup A amb direcció i sense direcció, grup B, grup $\mathrm{C}$ i D, amb direcció o sense direcció.

Les següents taules mostren els resultats per a ambdós col·lectius de treballadors a l'Uu segons la seua distribució per les categories laborals enumerades: 
Taula 2.

Grau de complicació per categories (PAS)

Complicada

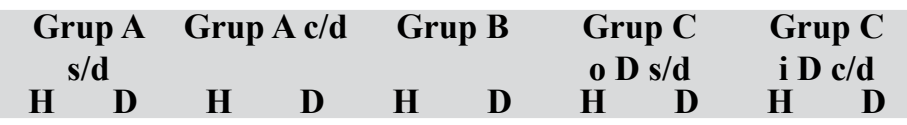

o molt $40 \% 48,1 \% 33,3 \% 42,9 \% 42,9 \% 53,3 \% 39,3 \% 62,6 \% 35,0 \% 50,0 \%$ complicada

Senzilla

o molt $40 \% 51,9 \% 57,2 \% 66,6 \% 57,1 \% 40,0 \% 46,5 \% 35,8 \% 55,0 \% 32,1 \%$ $\underline{\text { senzilla }}$

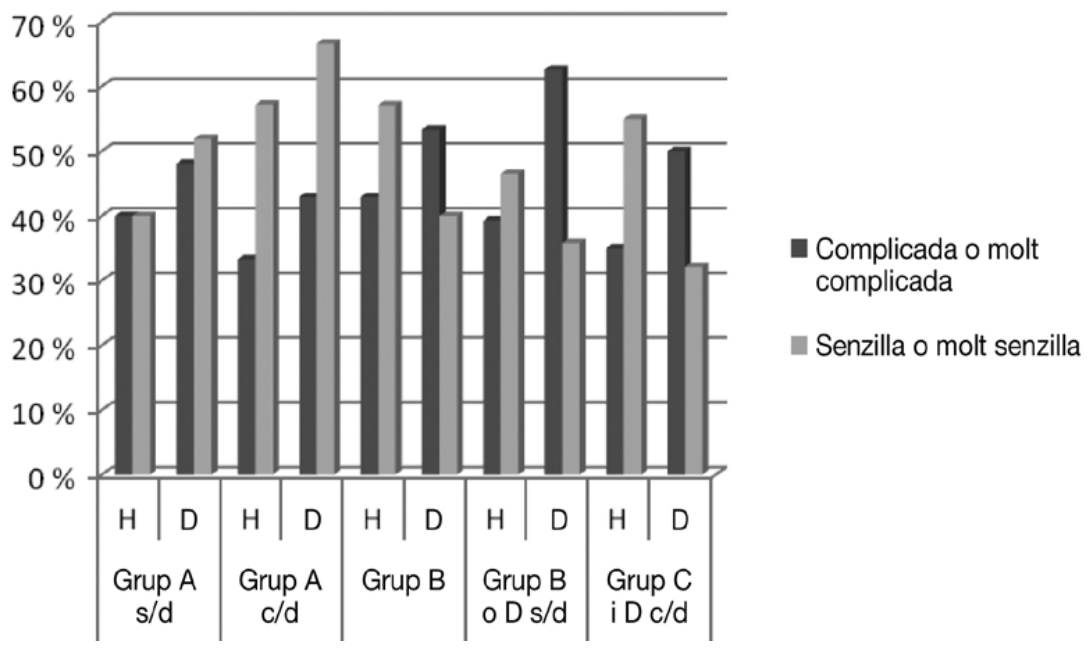

Gràfic 2.

Grau de complicació per categories (PAS)

Pel que fa al personal d'administració i serveis, són les dones dels grups B i C les que consideren més complicada la conciliació, i no resulta tan difícil per a les dones del grup A. Crida l'atenció que són 
les dones del grup A amb direcció aquelles a les quals els resulta senzilla o molt senzilla la conciliació.

Cap grup masculí del PAs arriba al $50 \%$ en el nombre de respostes que consideren que la conciliació és complicada o molt complicada. Al contrari, quasi un $60 \%$ dels homes del grup A amb direcció, B i C i $\mathrm{D}$ amb direcció consideren que és senzilla o molt senzilla.

Vegem ara la distribució entre les categories del PDI.

Taula 3.

Grau de complicació per categoria laboral i sexe

\begin{tabular}{ccccccccc} 
& $\begin{array}{c}\text { Professorat } \\
\text { funcionari }\end{array}$ & \multicolumn{2}{c}{$\begin{array}{c}\text { Personal } \\
\text { laboral }\end{array}$} & $\begin{array}{c}\text { Professorat } \\
\text { associat }\end{array}$ & $\begin{array}{c}\text { Personal } \\
\text { becari }\end{array}$ \\
& Complicada Senzilla & Complicada Senzilla & Complicada Senzilla & Complicada Senzilla \\
\hline $\mathrm{H}$ & $42,7 \%$ & $53,4 \%$ & $43,6 \%$ & $48,7 \%$ & $44,1 \%$ & $50,0 \%$ & $75 \%$ & $25 \%$ \\
$\mathrm{D}$ & $59,7 \%$ & $32,2 \%$ & $58,5 \%$ & $34 \%$ & $51,6 \%$ & $45,2 \%$ & $16,7 \%$ & $33 \%$ \\
\hline
\end{tabular}

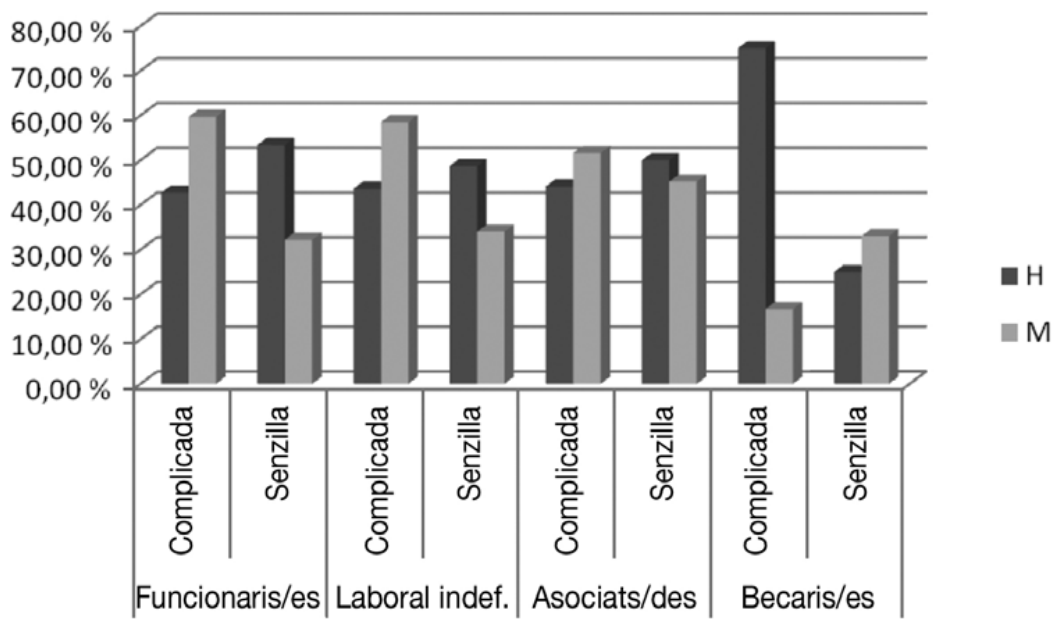

Gràfic 3.

Grau de complicació per categoria laboral i sexe 
Per a totes les categories, les dones consideren més complicada la conciliació que els homes. Les majors diferències per sexe dins de cada categoria laboral es produeixen en el funcionariat, segons els resultats proporcionats per l'enquesta i sense tenir en compte el personal becari, ja que el nombre de respostes en aquest grup ha sigut baix, per la qual cosa no és molt significatiu el percentatge resultant.

Les funcionàries superen en 17 punts percentuals els funcionaris en la consideració que els resulta complicada la conciliació; de manera inversa, els homes superen en 22 punts percentuals les dones en la consideració que la conciliació els resulta senzilla.

Les diferències per sexes es redueixen en la categoria dels laborals indefinits i del professorat associat.

El grau de complicació és semblant entre els funcionaris i les funcionàries i entre el col·lectiu de personal laboral indefinit i bastant pròxim per al professorat associat, si bé i com es repeteix en tots els encreuaments de variables que estem realitzant, per a les dones sempre resulta més complicat que per als homes excepte en el col·lectiu de personal becari on, com s'observa en el gràfic següent, la distància entre dones $\mathrm{i}$ homes es triplica a favor dels homes.

En els gràfics 4 i 5 hem desagregat les dades segons la consideració de complicació o senzillesa per a visualitzar millor els resultats en les diferents categories laborals del PDI. 


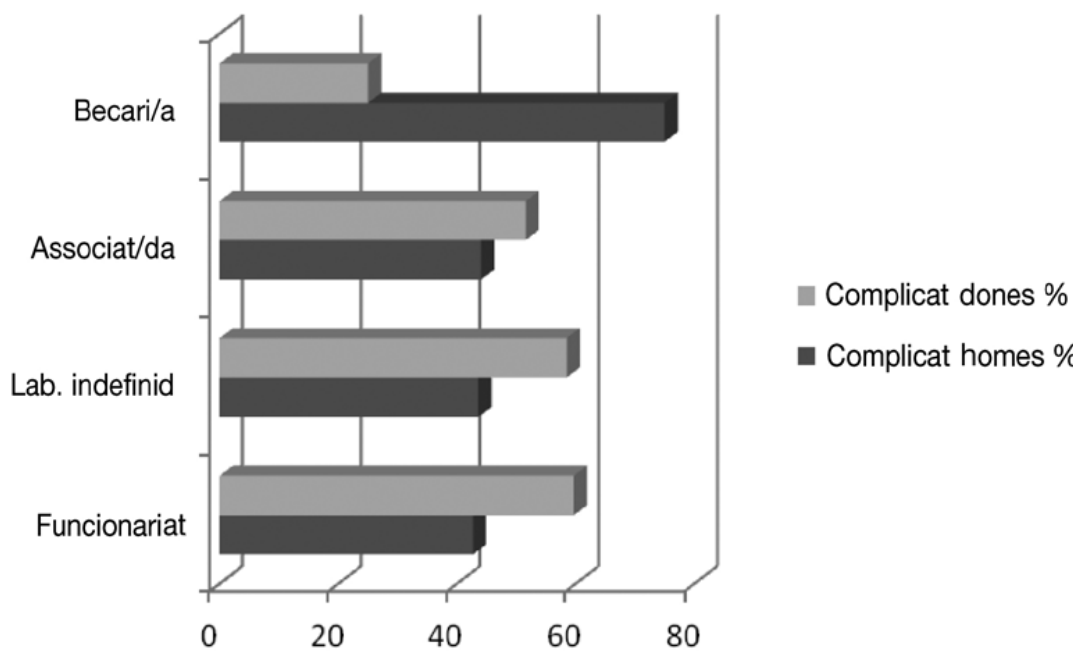

Gràfic 4.

PDI per categoria laboral que considera complicada o molt complicada la conciliació

Les dades del gràfic anterior s'oposen als del següent, que respon a la pregunta si la conciliació entre les tasques domèstiques i d'atenció i les laborals els resulta senzilla o molt senzilla. Els homes ho consideren més senzill en totes les categories laborals excepte en la del personal becari, fet que coincideix amb l'encreuament anterior referit a l'edat, en el qual també eren les dones joves les que consideraven més senzilla la conciliació. 


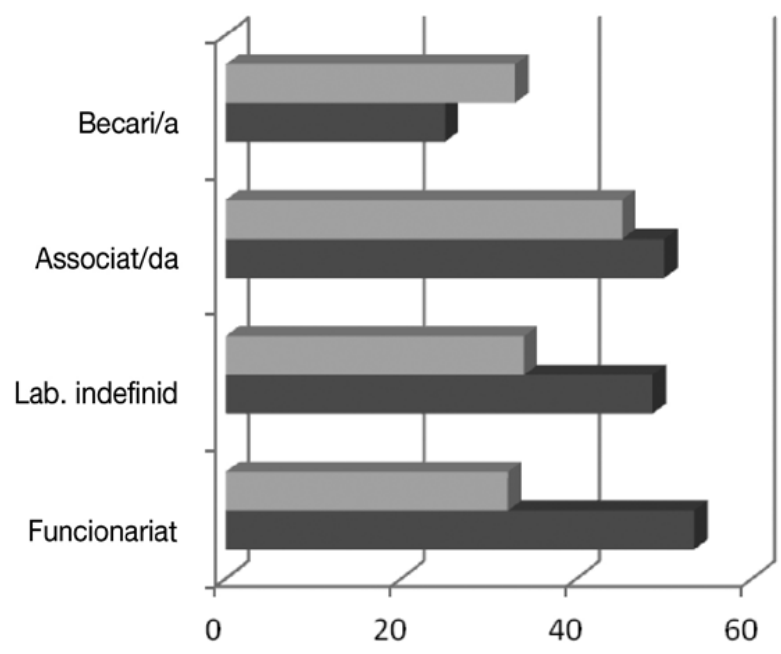

Senzill dones \%

Senzill homes \%

Gràfic 5.

PDI que considera senzilla o molt senzilla la conciliació

\subsection{COMPLICACIÓ SEGONS L’EDAT}

Atès que la conciliació reflecteix el fet de l'articulació del temps dedicat a la vida laboral i a la vida familiar, és lògic que siga més complicada la conciliació per a aquelles persones amb més obligacions familiars relacionades amb l'atenció, ja siga a criatures o a persones grans dependents.

Aquesta informació l'obtenim de l'encreuament de dues variables explicatives significatives, com són el nombre de fills i filles i l'edat, ja que les dures variables estan relacionades.

Per això, en les següents taules desagreguem la població enquestada per grups d'edat amb la finalitat de conèixer quins grups etaris tenen més dificultats per a conciliar tant en el PAS com en el PDI segons els resultats de l'enquesta. 
Iniciem l'exposició al·ludint al grau de complicació per a conciliar segons edat i sexe per al PAS.

Taula 4.

Grau de complicació per edat i sexe (PAS)

\section{Menys de $33 \quad$ 34-39 anys 40-49 anys Més de 50 \\ anys}

Homes Dones Homes Dones Homes Dones Homes Dones

Complicat $33,3 \% 33,3 \% 34,5 \% \quad 57,1 \% \quad 43,9 \% \quad 64,6 \% \quad 21,4 \% \quad 35,0 \%$

Senzill $\quad 66,7 \% \quad 50,0 \% \quad 51,7 \% \quad 38,1 \% \quad 48,8 \% \quad 31,7 \% \quad 57,2 \% \quad 60 \%$

Gràfic 6.

Grau de complicació per edat i sexe per al PAS 
La lectura de la taula i del gràfic manifesta de manera convincent el pes que l'exercici del rol tradicional té per a les dones del pas en els grups d'edat en què amb més freqüència s'és mare. És a dir, que les dones i els homes de menys de 33 anys veuen més senzill conciliar la vida laboral amb la familiar, però en els grups d'edat compresos entre els 34 i els 49 anys, és a dir, els grups en què majoritàriament es realitza la criança, les diferències entre els sexes s'aguditzen $i$ arriba a ser de més de 20 punts percentuals la diferència pel que fa a la complicació per a les dones.

Es reflecteix, doncs, en aquests grups d'edat la presència de «la doble jornada» en les dones i com a conseqüència d'això, l'asimetria en el repartiment de les tasques domèstiques i d'atenció en la pare$11 a$.

Els homes, pel contrari, consideren la conciliació més senzilla en tots els grups d'edat excepte en el de més de 50 anys, grup en què estan lleument per davall de les dones, si bé és el grup amb nombre més gran de $\mathrm{Ns} / \mathrm{NC}$ : un 21,4 \% dels homes de més de 51 anys. És en aquest grup d'edat on la conciliació es considera menys complicada tant per a dones com per a homes, fet motivat segurament per tenir els fills i filles més edat o haver-se'n anat ja de casa, per la qual cosa les responsabilitats familiars s'atenuen.

Vegem en la taula següent els resultats per al professorat.

Taula 5.

Grau de complicació per edat i sexe (PDI)

\begin{tabular}{lcccccccc} 
& \multicolumn{2}{c}{$\begin{array}{c}\text { Menys 33 } \\
\text { anys \% }\end{array}$} & \multicolumn{2}{c}{$\begin{array}{c}34-39 \\
\text { anys \% }\end{array}$} & \multicolumn{2}{c}{$\begin{array}{c}\text { 40-49 } \\
\text { anys \% }\end{array}$} & \multicolumn{2}{c}{$\begin{array}{c}\text { Més de 50 } \\
\text { anys \% }\end{array}$} \\
& Homes & Dones & Homes & Dones & Homes & Dones & Homes & Dones \\
Complicat & 45,5 & 40,0 & 46,9 & 54,2 & 47,5 & 60,9 & 30,6 & 41,2 \\
Senzill & 54,6 & 35,0 & 45,9 & 35,4 & 47,5 & 33,3 & 58,3 & 41,2 \\
\hline
\end{tabular}




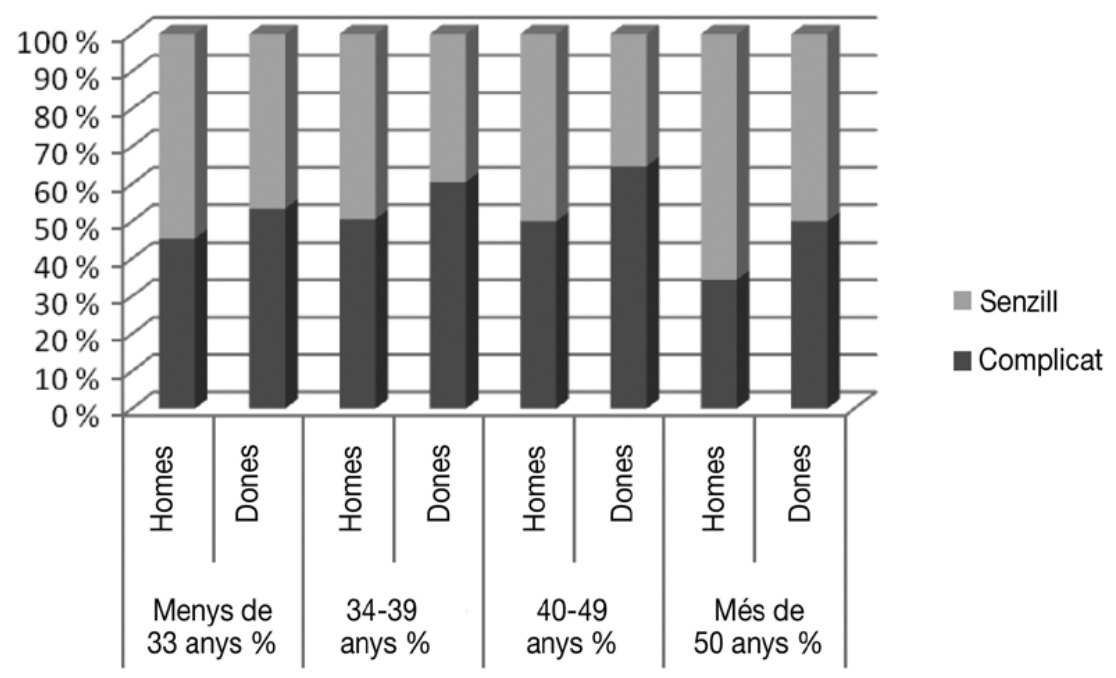

Gràfic 7.

Grau de complicació per edat i sexe per (PDI)

Clarament s'observa que el grup d'edat amb més problemes per a conciliar és el de 34 a 49 anys, motivat pel fet que és quan habitualment es tenen les criatures avui en dia i quan encara estan en edat de demanar atenció absorbent per part dels progenitors.

El percentatge s'inverteix amb les persones de més de 50 anys, que en una proporció superior al $50 \%$ manifesta tenir-ho senzill o molt senzill.

Com a dada que completa l'anterior informació és necessari afegir que el nombre de respostes assenyalades com Ns/NC és del $25 \%$ en el cas de les dones de menys de 33 anys PDI, incidència que potser tinga a veure amb el fet que és aquest l'únic grup d'edat en què els homes consideren més complicada la conciliació que les dones.

Respecte a la complicació, crida l'atenció que en les respostes «Senzill o molt senzill» són els homes, per a tots els grups d'edat, els que 
així ho consideren, mentre que en les persones que responen que els resulta complicada o molt complicada la conciliació, excepte el grup d'homes de menys de 33 anys com hem assenyalat en el paràgraf anterior, són les dones.

La diferència més elevada entre els sexes pel que fa a la complicació en la conciliació de les tasques domèstiques i d'atenció amb les laborals té lloc en la dècada dels quaranta. En aquest grup d'edat, el $60,9 \%$ de les dones ho consideren complicat o molt complicat, 13 punts per damunt de la resposta donada pels homes: considerem que l'explicació es troba en el fet que les dones acadèmiques tenen a una edat més tardana les criatures.

En resum, la tendència general indica que tant per a homes com per a dones els grups d'edat compresos entre els 34 i els 49 anys són els més complicats per a conciliar la vida laboral i la familiar, per motius obvis de la criança en què ambdós membres de la parella estan implicats; ara bé, i com ja estem veient al llarg del text, la complicació no és igual per als dos sexes, ja que s'impliquen molt més les dones en les tasques d'atenció la qual cosa, i com també es reflecteix en les dades del Diagnòstic presentat en el capítol 2, té conseqüències en la carrera acadèmica de les dones, ja que només un $20 \%$ de les professores assoleixen la càtedra.

\subsection{COMPLICACIÓ SEGONS EL NOMBRE DE FILLS I FILLES}

Si bé la maternitat/paternitat suposa un canvi en la distribució de rols i en el temps dedicat a la cura de les criatures, també és cert que el dit temps s'incrementa en relació directament proporcional al nombre de fills i filles.

Les següents taules confirmen la influència que el nombre de fills i filles té en el PAs i en el PDI respecte de considerar la conciliació com a complicada o senzilla. 
Taula 6.

Grau de complicació per a conciliar segons el nombre de fills i filles (PAS)

\begin{tabular}{lcccccc} 
& \multicolumn{2}{c}{ Un/a fill/a \% } & \multicolumn{2}{c}{ Dos fills/es \% } & \multicolumn{2}{c}{ Tres fills/es \% } \\
& Home & Dona & Home & Dona & Home & Dona \\
\hline $\begin{array}{l}\text { Complicat o } \\
\text { molt complicat }\end{array}$ & 52,0 & 62,2 & 48,1 & 74,5 & 50.0 & 85.7 \\
$\begin{array}{l}\text { Senzill o molt } \\
\text { senzill }\end{array}$ & 40,0 & 33,3 & 44,4 & 23,5 & 50,0 & 14,3 \\
\hline
\end{tabular}

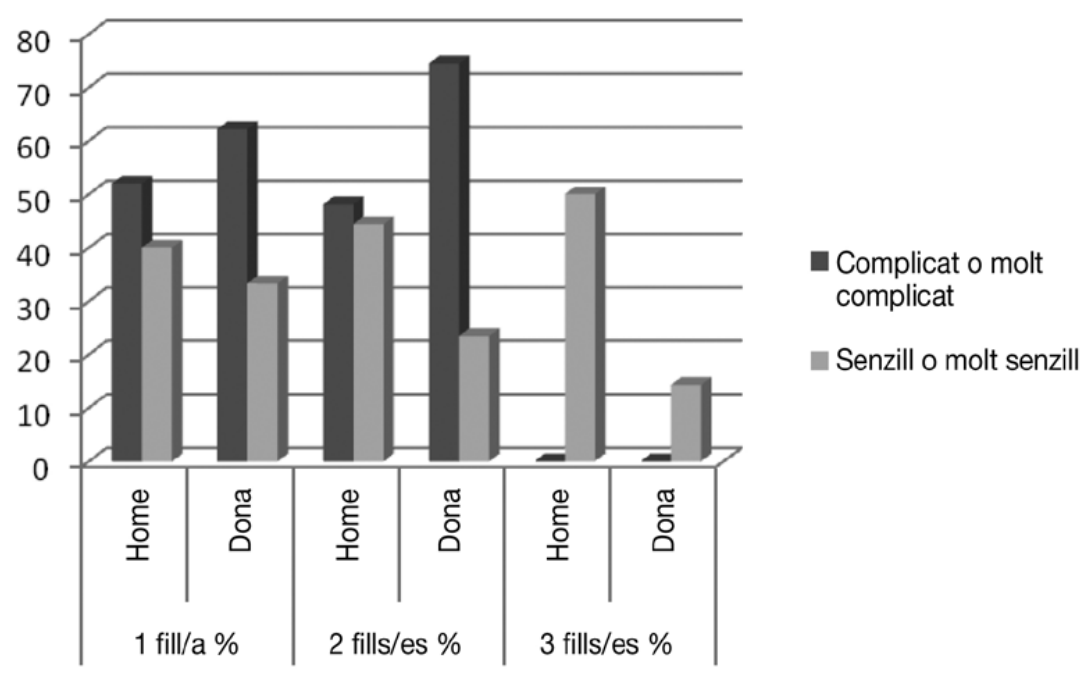

Gràfic 8 .

Grau de complicació per a conciliar segons nombre de fills i filles (PAS) 
Taula 7.

Grau de complicació per a conciliar segons el nombre de fills i filles (PDI)

\begin{tabular}{|c|c|c|c|c|c|c|}
\hline & \multicolumn{2}{|c|}{ Un fill/a } & \multicolumn{2}{|c|}{ Dos fills/es } & \multicolumn{2}{|c|}{ Tres fills/es } \\
\hline & Home & Dona & Home & Dona & Home & Dona \\
\hline $\begin{array}{l}\text { Complicat } \\
\text { o molt } \\
\text { complicat }\end{array}$ & $50 \%$ & $68,6 \%$ & $53,5 \%$ & $66,7 \%$ & $88,9 \%$ & $90,9 \%$ \\
\hline $\begin{array}{l}\text { Senzill o } \\
\text { molt senzill }\end{array}$ & $39,6 \%$ & $28,6 \%$ & $39,5 \%$ & $28,6 \%$ & $11,1 \%$ & $0,0 \%$ \\
\hline
\end{tabular}

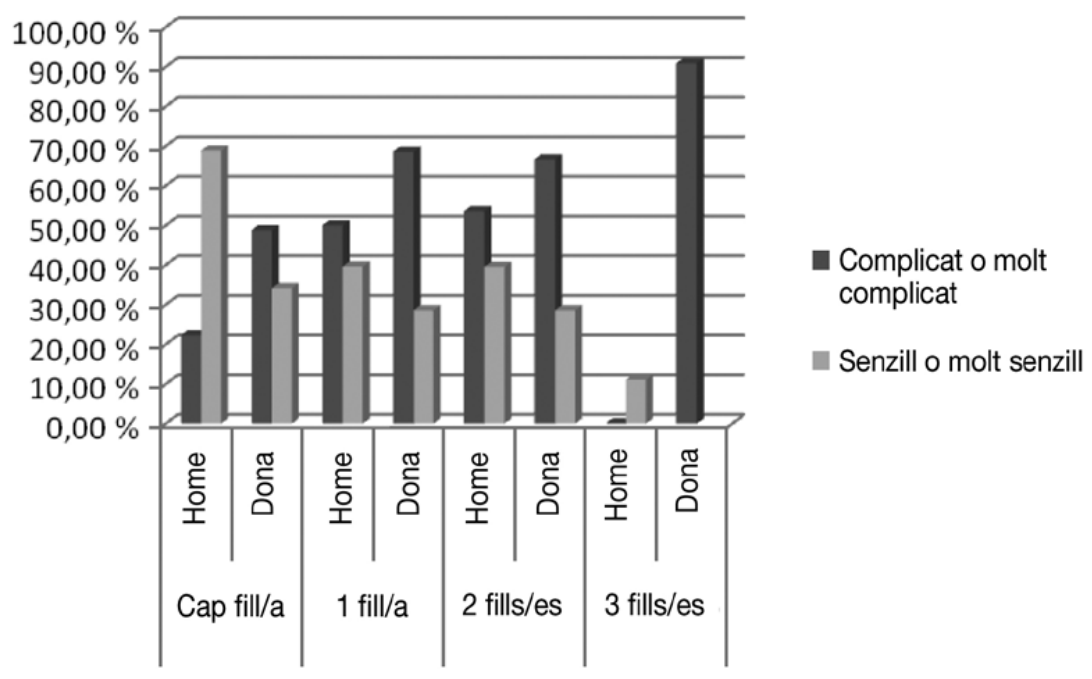

Gràfic 9.

Grau de complicació per a conciliar segons el nombre de fills i filles (PDI) 
El gràfic 9 reflecteix que, com sempre, a les dones els resulta molt més complicada la conciliació que als homes; ara bé, aquest grau de complicació s'incrementa a mesura que el nombre de fills i filles és més alt, de manera que arriben a respondre el $90 \%$ de les dones que tenen tres fills i filles que els resulta complicada o molt complicada la conciliació.

El fet més destacable i vertader exponent de la persistent divisió de rols entre els gèneres és que juntament amb el fet anterior, en allusió a què el $90 \%$ de dones amb tres fills i filles considera complicada la conciliació, al $70 \%$ d'homes sense fills i filles els resulta senzilla o molt senzilla.

\subsection{CONCLUSIONS}

De l'anterior es dedueix que tant per a les dones del PAs com per a les del PDI, la conciliació de la vida laboral i familiar resulta més complicada que per als seus companys homes.

Es constata, doncs, com la continuïtat en l'exercici del rol tradicional d'atenció en les dones i el consegüent exercici de la «doble jornada» es reflecteix en els resultats de l'enquesta pel que fa al grau de dificultat per a conciliar.

D'altra banda, es conclou també que si bé el grau de dificultat per a conciliar és bastant semblant entre dones del PAS i del PDI no succeeix el mateix per als homes. Segons indiquen els resultats de l'enquesta, els homes del PDI manifesten més dificultat per a conciliar que els homes del PAS.

L'edat, tant per a un col·lectiu com per a l'altre, és també un factor central en l'expressió del grau de complicació, ja que les exigències respecte a l'atenció en els grups centrals, entre 31 i 50 anys, no són les mateixes que en la resta, i per aquest motiu, que siguen aquests grups els que en major grau manifesten dificultats per a conciliar. 
També el nombre de fills i filles indica un major grau de dificultat. Són aquelles persones entrevistades, tant homes com dones amb tres fills i filles les que reconeixen tenir més dificultats per a conciliar.

Aquestes dificultats per a conciliar reflecteixen en última instància la insuficient coresponsabilitat a les llars de les persones enquestades, la qual cosa aguditza les dificultats que les dones tenen per a conciliar. 


\section{CONCLUSIONS \\ I RECOMANACIONS}

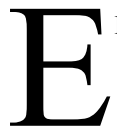

LS RESULTATS DE L'ENQUESTA sobre la conciliació de la vida laboral, familiar i personal a la Universitat Jaume I mostren que la conciliació de la vida laboral i familiar continua sent una responsabilitat predominantment femenina, també a la Universitat.

Les dones s'han incorporat decididament al treball docent, investigador i administratiu de l'educació superior o universitària, això és, a l'espai públic. La comparació de les dades de la plantilla de la Universitat Jaume I entre els anys 1991 i 2013 indica que el PDI femení s'ha incrementat en 12 punts percentuals, superant en quasi 5 punts la mitjana estatal, situada en el 38,8 \%.

Però, aquest canvi no ha vingut acompanyat d'una integració dels homes en l'espai domèstic i d'atenció, almenys en termes equivalents. Els resultats obtinguts confirmen la persistència de la divisió sexual del treball entre les dones i els homes que formen part de la plantilla de la Universitat a pesar dels canvis succeïts des de la incorporació femenina al mercat laboral. També revelen les dificultats que s'aprecien per a conciliar la vida laboral i familiar, especialment en el cas de les dones, tant del PDI com del PAS. Una diferència que denota el pes que el rol domèstic i d'atenció manté sobre elles.

Les dades evidencien una vegada més que el repartiment de les tasques domèstiques i d'atenció és asimètric, de tal manera que les dones continuen realitzant les distintes tasques domèstiques en major proporció que els homes. La coresponsabilitat, doncs, tampoc està present en les parelles en què algun dels components de les quals treballa a la Universitat. En aquest sentit, les treballadores del PAs i del PDI enquestades perceben aquest repartiment desigual amb més claredat que els homes. Una troballa que, al seu torn, permet conclou- 
re que hi ha més homogeneïtat en l'exercici de les dites tasques en el gènere femení, en la mesura que no s'obté la mateixa similitud en les respostes dels homes del PAs i del PDI.

Els resultats mostren una certa participació masculina en 1'exercici de les tasques domèstiques i en l'atenció a fills i filles, tal com indiquen les dades obtingudes amb les preguntes directes sobre qui realitza les tasques domèstiques i d'atenció i amb les qüestions dirigides a conèixer la percepció existent respecte d'això. Entre les tasques domèstiques més simètriques destaquen les tasques de neteja i la compra setmanal. En l'atenció a fills i filles, els homes del PDI participen amb més intensitat en la seua atenció en les edats més primerenques; la seua participació és més elevada que la femenina únicament quan es tracta d'ajudar-los en les tasques escolars.

S'ha de tenir en compte que en l'articulació de la vida laboral i personal interfereixen una sèrie de variables estructurals $\mathrm{i}$ ideològiques que expliquen la major o menor complicació que les persones troben a l'hora de conciliar. Entre les variables estructurals es troben l'edat i el nombre de fills i filles. Les dues variables estan relacionades i manifesten de manera contundent el pes que el rol de gènere femení i, en concret, la maternitat, tenen a l'hora de dificultar l'encaix dels temps dedicats a una o a l'altra tasca.

Pel que fa a les variables ideològiques, fan referència al pes que els rols de gènere tenen en els comportaments $i$ actuacions de les persones i que poden ser més o menys tradicionals.

Els resultats de l'enquesta mostren que els enquestats i, sobretot, les enquestades, expressen un grau més alt de dificultat per a conciliar a mesura que augmenta el nombre de filles o fills. En el cas dels homes enquestats, els que formen part del PDI manifesten més dificultat que els seus companys del pas.

Així mateix, es conclou que les persones de més de cinquanta anys, en especial els homes, mostren comportaments més tradicionals respecte als rols de gènere - possiblement com a reflex d'una generació marcada encara pels valors patriarcals de la dictadura i que van ser socialitzades en rols de gènere clarament diferenciats. Un factor que 
ha influït, sens dubte, en la menor representació femenina en aquest grup etari del personal de la Universitat.

També la socialització en els rols de gènere tradicionals pesen i es reflecteixen en les dades de l'enquesta. L'exercici de les tasques domèstiques i d'atenció continua sent «assumpte» femení. Aquesta «doble jornada», «doble presència» $\mathrm{o}$ «doble treball» influeix de manera directa en l'exercici de la carrera acadèmica o en l'ascens a llocs de responsabilitat. Les dades obtingudes mostren l'increment de dones en el PDI, però, al mateix temps, també posen de manifest que només el $20 \%$ de les càtedres de la Universitat Jaume I està ocupat per dones, i que en el grup A amb direcció, el 60 \% són homes.

Considerem, doncs, que la coresponsabilitat és fonamental per a aconseguir un grau més elevat d'igualtat entre dones i homes, així com per a derrocar el denominat sostre de vidre que impedeix que moltes dones aconseguisquen una major promoció acadèmica o jeràrquica.

D'altra banda, els resultats manifesten el desconeixement de la majoria de les persones enquestades sobre els recursos disponibles per a conciliar la vida familiar i laboral. Les dones són més coneixedores que els homes dels dispositius de conciliació existents, tant en el PDI com en el PAS. Un resultat que troba la seua explicació en el fet que són elles les usuàries més habituals de les dites mesures, a pesar que s'aproven per a ser utilitzades tant per homes com per dones. En particular, el PDI masculí és el que menys coneix els mecanismes de conciliació. Entre els instruments de conciliació existents, el I Pla d'Igualtat de la Universitat Jaume I és més conegut que la legislació vigent en matèria de conciliació. Les mesures de conciliació de la vida familiar i laboral més utilitzades són les que no suposen reducció salarial o minva d'oportunitats de promoció en la carrera acadèmica.

Els resultats obtinguts i les conclusions formulades permeten enunciar una sèrie de recomanacions que es consideren útils per a millorar la conciliació entre la vida laboral i familiar i, en especial, la coresponsabilitat: 
- Resulta necessari reforçar el coneixement del model de coresponsabilitat perquè, progressivament, es vaja incorporant a la mentalitat de la societat, d'homes i dones, i que les expectatives generalitzades d'elles i d'ells tant en l'àmbit laboral com en el familiar, així com l'assignació tradicional de rols, canvien, de tal manera que l'espai de producció mercantil i l'espai de les cures compten amb una valoració equivalent.

- Ha de potenciar-se la informació i la formació en matèria de conciliació, orientada fonamentalment cap als homes tant del PAS com del PDI, fent especial insistència en les mesures menys conegudes. Ambdues iniciatives han de partir del contingut del I Pla d'Igualtat de la Universitat Jaume I. Les dones joves del PDI han de ser destinatàries d'una atenció particular en aquesta qüestió.

- En tant que les mesures amb repercussió en les condicions laborals i en la millora de la posició professional presenten un índex d'ús menor, es creu convenient examinar de quina forma pot contribuir la normativa específica de la Universitat Jaume I a minimitzar els efectes adversos dels dispositius previstos en la legislació, fins i tot adoptant mesures que permeten compensar-los, almenys de manera parcial.

- Es recomana el disseny i l'aplicació de noves actuacions per a promoure que els homes usen més les mesures de conciliació, afavorint així que les responsabilitats familiars no recaiguen sobre les dones i avançant cap a la solució del problema de la desigualtat social.

- En el cas del PAs, haurien de realitzar-se campanyes informatives $i$ formatives per a les dones del PAS en què es reflectira l'impacte posterior de l'ús de les mesures de conciliació que requereixen una adaptació laboral.

- En el cas del PDI, crida l'atenció l'escassa utilització de la mesura «Preferència en l'elecció d'horaris lectius», tant entre les dones com entre els homes, a pesar que representa tan sols avantatges, sense contrapartides. Les dificultats que pot estar creant 
la seua aplicació han de ser corregides - per exemple, que no siga tan sols una qüestió de departament sinó també de centre, ja que és més fàcil ajustar els horaris a les assignatures que imparteix el PDI que ho necessita, que haver d'ajustar la distribució de les assignatures entre el PDI en funció dels horaris.

- Finalment, es recomana la realització d'una anàlisi longitudinal d'ací a deu anys per a determinar si s'han observat canvis i si les joves actuals mostren comportaments diferents en les seues trajectòries laborals. 


\section{BIBLIOGRAFIA}

Albert, Rocio et alii (2010): «Las políticas de conciliación de la vida familiar y laboral desde la perspectiva del empleador», Cuadernos de Trabajo, n. 2.

AlcaÑIz, Mercedes (2004): «Conciliación entre las esferas pública y privada: ¿Hacia un nuevo modelo en el sistema de géneros?», Sociologia. Problemas e práticas, n. 44, pp. 47-70.

- (2008): «Proceso de individualización y reorganización de biografías, trabajos e identidades», Arxius de Ciències Socials, n. 19, pp. 5-18.

- (2013): «Estrategias de conciliación y segmentación social: la doble desigualdad», Sociologia. Problemas e práticas, n. 73, pp. 35-58.

Amorós, Celia i Ana de Miguel (eds.) (2005): Teoría Feminista. De la Ilustración a la Globalización, 3 vols., Minerva, Madrid.

Argüelles Blanco, Ana Rosa (2011): «Conciliación y corresponsabilidad en la ordenación del tiempo de trabajo: comentario de las disposiciones normativas vigentes en las universidades públicas catalanas», Revista Interdisciplinar de Estudios de Género, n. 1, pp. 15-22.

Balaguer Callejón, M. Luisa (2005): Mujer y Constitución: la construcción jurídica del género, Cátedra, Madrid.

Balbo, Laura (1994): «La doble presencia», en Borderías, Carrasco y Alemany (comps.): Las mujeres y el trabajo. Rupturas conceptuales, Icaria, Barcelona.

Ballarín, Pilar (1995): «La construcción de un modelo educativo de Utilidad doméstica» en Fraisse y Pierrot (eds.): Historia de las mujeres. El siglo XIX. Círculo de Lectores, Barcelona. 
Ballester Pastor, M. a Amparo (2000): La ley 39/1999 de conciliación de la vida familiar y laboral: una corrección de errores con diez años de retraso, Tirant Lo Blanch, Valencia.

Beauvoir, Simone de (2000): El segundo sexo, Cátedra, Madrid.

Beck, Ulrich i Elisabeth Beck-Gernsheim (2003): La individualización. El individualismo institucionalizado y sus consecuencias sociales y politicas, Paidós, Barcelona.

Becker, Gary (1987): Tratado sobre la familia, Alianza Editorial, Madrid.

Beltrán, Elena i Maquieira, Virginia (eds.) (2001): Feminismos. Debates teóricos contemporáneos, Alianza, Madrid.

Bock, Gisela (2001): La mujer en la historia de Europa, Barcelona, Crítica.

Borderías, Cristina; Carrasco, Cristina i Alemany, Carmen (1994): Las mujeres y el trabajo. Rupturas conceptuales, Icaria, EUHEM, Madrid.

Borrajo Dacruz, Efrén (2009): Introducción al Derecho del Trabajo, Tecnos, Madrid.

Borrás, Vicente; Torns, Teresa i Moreno, Sandra (2007): «Las políticas de conciliación: políticas laborales versus políticas de tiempo», Papers, n. 83, pp. 83-96.

CAmpillo, InÉs (2010): «Políticas de conciliación de la vida laboral y familiar en los regímenes de bienestar mediterráneos. Los casos de Italia y España», Política y sociedad, vol. 47, n.1, pp. 89-213.

Carrasco, Cristina (2003): Tiempos, trabajos y flexibilidad: una cuestión de género, Instituto de la Mujer, Madrid.

Carrasco, Cristina i Serrano, Mónica (2007): Compte satèl-lit de la producció domèstica de les llars de Catalunya (2001), Institut Català de les Dones, Barcelona.

Carrasco, Cristina; Borderías, Cristina i Torns, Teresa (2011): El trabajo de cuidados. Historia, teoría y políticas, Los Libros de la Catarata, Madrid. 
Chinchilla, Nuria; Poelmans, Steven i León, Consuelo (2003): «Políticas de conciliación trabajo-familia en 150 empresas españolas», Documento de Investigación, n. 498, IESE, Business School.

Cifre, Eva; Salanova, Marisa i Franco, Joan. (2011): «Riesgos psicosociales de hombres y mujeres en el trabajo: ¿una cuestión de diferencias?», Gestión de Riesgos Laborales, n. 82, pp. 28-36.

Combes, Danièle i Haicault, Monique (1994): «Producción y reproducción, relaciones sociales de sexo y de clase» en Borderías, Carrasco y Alemany (comps.): Las mujeres y el trabajo. Rupturas conceptuales, Icaria, FUHEM.

Comisión de las Comunidades Europeas (1993): Crecimiento, competitividad y empleo. Retos y pistas para entrar en el siglo XXI, document PDF consultat el 15 de gener de 2014 en http://biblioteca. cunef.edu/gestion/catalogo/doc_num.php?explnum_id=449

Comins, Irene (2009): Filosofía del cuidar, Icaria, Barcelona.

Crompton, Rosemary i Lyonnette, Claire (2010): «Family, class and gender strategies in mother employment and childcare en Scott, Joan, Crompton, Rosemary and Lyonnette, Claire», Gender inequalities in the $21^{\text {st }}$ century. New barriers and continuity constraints, Edward Elgar, Cheltenham.

Datos y Cifras del Sistema Universitario Español. Curso 2012-2013 (2013): Ministerio de Educación, Cultura y Deporte, Madrid.

Di Nicola, Giula Paola (1991): Reciprocidad hombre-mujer: Igualdad y diferencia, Narcea Ediciones, Madrid.

Durán, M.a Ángeles (1972): El trabajo de la mujer en España. Un estudio sociológico, Tecnos, Madrid.

- (1986): La jornada interminable, Icaria, Barcelona.

Esping-Andersen, Gosta (2010): Los tres grandes retos del estado del bienestar, Ariel, Barcelona.

Fenollosa, Carmen (1992): Acercamiento al fenómeno de la desigualdad sexual en la Universitat Jaume I, Asparkia. Investigació Feminista, n. 1, pp. 15-37. 
Flórez-Estrada, María (2011): De ama de casa a Mulier economics. Sexo, género, subjetividad y economía en Costa Rica Contemporánea, Universidad de Costa Rica, San José de Costa Rica.

Fraisse, Genoveve y Perrot, Michelle (1995): Historia de las mujeres, vol. IV, siglo XIX, Círculo de Lectores, Barcelona.

Friedan, Betty (1983): La segunda fase, Plaza\&Janés, Barcelona.

Fundació Isonomia (2009): En igualtat, aquest és el nostre pla, Fundació Isonomia, Castelló de la Plana: http://documents.uji.es/ alfresco/d/a/workspace/SpacesStore/dd43cc79-7dd8-41a6-af852850b5f99098/ujidi.pdf?guest=true

Garrigues Giménez, Amparo (2004): La maternidad y su consideración jurídico-laboral y de Seguridad Social. Centro Económico y Social, Madrid.

Gilligan, Carol (1982): In a different voice: psychological theory and women's development, Harvard University Press, Cambridge, Massachussets.

Hakim, CAtherine (2005): Modelos de Familia en las Sociedades Modernas. Ideales y Realidades, CIS, Madrid.

Harding, SAndra (1986): The science question in feminism. Cornell University Press. Ithaca-Londres.

HeEry, Edmund (2006): «Equality Bargaining: Where, Who, Why?», Gender, Work and Oragnization, vol. 13, n. 6, pp 522-542.

Hochschild, ARLi (1989): The second shift. Working families and the revolution at home, Pinguin, Londres.

- (2001): «Las cadenas mundiales de afecto y asistencia y la plusvalía emocional», en Anthony Giddens y William Hutton (coords.): En el Limite, Tusquets, Barcelona.

Instituto de la Mujer (2013): Mujeres en cifras. www.inmujer.gob.es Instituto Nacional de Estadística (INE). www.ine.es

IzQuiERdo, M. a Jesús (1995): El malestar en la desigualdad, Icaria, Barcelona.

Jover Ramírez, Carmen (2013): «La difícil supervivencia de la conciliación entre la vida laboral y familiar en tiempos de crisis y reforma», Aranzadi Social. Revista Doctrinal, vol. 6, n. 4, pp. 93-125. 
Kan, Man Yee i Gershuny, Jonathan (2010): «Gender segregation and bargaining in domestic labour: evidence from longitudinal time-use data» en Scott, Jacqueline; Crompton, Rosemary; Lyonette, Clare (eds.), Gender inequalities in the $21^{\text {st }}$ century. New Barriers and Continuing Constraints. Edward Elgar, Cheltentham, UK.

Lagarde, Marcela (2009): La Política Feminista de la Sororidad, www.mujeresenred.net [Consulta: 25 Febrer 2014].

Lapuerta, Irene (2012): Employment, motherhood and Parental leaves in Spain, tesis doctoral, UPF, Barcelona [Consulta: 17 febrer 2014].

LeRner, Gerda (1990): La creación del patriarcado, Crítica, Barcelona.

Lipovetsky, GiLles (2003): La tercera mujer. Permanencia y revolución de lo femenino, Anagrama, Barcelona.

Mandel, Hadas (2009): "Configurations of gender inequality: the consecuences of ideology and public policy», British Journal of Sociology, 60 (4), pp. 693-718.

Martí, Ana i Poveda, María (2008): «El empleo de hogar: desigualdad y poder entre mujeres», a Asparkia. Investigació Feminista, n. 20, pp. 99-122.

Morant, Isabel (2006): Historia de las mujeres en España y América Latina, Cátedra, Madrid.

Murillo, Soledad (2006): El mito de la vida privada. De la entrega del tiempo propio, Siglo XXI, Madrid.

NASH, MARY (1995): «Identidad cultural de género, discurso de la domesticidad y la definición del trabajo de las mujeres en la España del siglo XIX» en Fraisse y Pierrot (eds.): Historia de las mujeres. Siglo XIX. Círculo de Lectores, Barcelona.

Observatorio de Recursos Humanos (2013): Las tareas pendientes de empresas y trabajadores para contribuir al bienestar laboral, www.observatoriorh.com [Consulta: 4 març 2014].

Posada Kubissa, Luisa (s/f), Patriarcado y Sororidad (O la Sororidad Como Revulsivo Contra el Patriarcado), www.mujeresenred. net [Consulta: 25 febrero 2014]. 
Primer Informe sobre la Desigualdad en España (2013): Fundación Alternativas, Madrid.

RADL PhILIPP, RITA (2003): «Transformaciones en el comportamiento en función del género en la vejez: el caso de las relaciones familiares actuales entre abuelas, abuelos y nietos y nietas», Papers, 70, pp. 117-134.

Rivero Recuento, Álvaro (dir.) (2005): Conciliación de la vida familiar y laboral: situación actual, necesidades y demandas, Instituto de la Mujer, Madrid.

RodRíGUEZ FERNÁNDEZ, M. Luz (2014): «Efectos de la crisis económica sobre el trabajo de las mujeres»: Relaciones Laborales, Revista críticas de teoría y práctica, n. 1, pp. 69-83.

RodríGuez RodríGuez, Emma (2010): Instituciones de conciliación de trabajo con cuidados familiares, Bomarzo, Albacete.

Rodríguez, M. Carmen i Peña, José Vicente (2009): «¿Es posible compatibilizar familia y trabajo? Análisis cualitativo del discurso sobre la conciliación de la vida laboral y familiar», Documentación Social, 152, pp. 185-202.

Román, María i Martínez, Ana Mercedes (2005): «Las cadenas globales de cuidados: un análisis socio-demográfico», Sociedad y Utopía, 2, pp. 261-278.

Sarraceno, Chiara (2004): «A igualdade difícil: Mulheres no Mercado de Trabalho em Itália e a questão não resolvida da conciliação» en Sociología. Problemas e práticas, n. 44, pp. 27-46.

Salido, Olga (2001): La movilidad ocupacional de las mujeres en España. Por una sociología de la movilidad femenina, cIs, Madrid.

Salido, Olga i Moreno, Luis (2007): «Bienestar y políticas familiares en España», Política y sociedad, vol. 44, n. 2, pp. 101-114.

Saltzman, Janet (1992): Equidad y género. Una teoría integrada de estabilidad y cambio, Cátedra, Madrid.

SAU, Victoria (1995): El vacio de la maternidad: madre no hay más que ninguna, Icaria editorial, Barcelona. 
Sevilla Merino, Julia (2008): «Reforma estatutaria y perspectiva de género», Corts. Anuario de Derecho Parlamentario, n. 20, pp. 1766.

Tobío, Constanza (2005): Madres que trabajan. Dilemas y estrategias, Cátedra, Feminismos, Madrid.

Torns, TEResa (2005): «De la imposible conciliación a los permanentes malos arreglos», Cuadernos de Relaciones Laborales, vol. 23, n. 1, pp. 15-33.

Torns, Teresa; Borràs, Vicent; Recio, Carolina i Moreno, Sara (2011): «El temps de treball i el benestar quotidià», Arxius de Ciències Socials, n. 24, pp. 35-46.

Torns, TEResa (2011): «Las mujeres y el empleo en España. ¿Un futuro venturoso?», Retos y oportunidades para la igualdad de género, FOREM, Madrid.

Ventura Franch, Asunción (1999): Las mujeres y la Constitución Española de 1978, Instituto de la Mujer, Madrid.

VAN W ANROOY, Brigid (2009): «Women at Work in Australia: Bargaining a Better Position? », Australian Bulletin of Labour, vol. 35, Issue 4, pp. 611-628.

Walby, Sylvia (1990): Theorising Patriarchy, Blackwell, Oxford. 


\section{AUTORES I AUTORS DE LA PUBLICACIÓ}

\section{EDITORA}

Mercedes AlcañIz Moscardó (moscardo@uji.es)

Professora titular de Sociologia a la Universitat Jaume I i directora de la Unitat d'Igualtat de l'us des de febrer de 2013. Una de les seues línies d'investigació és la conciliació entre la vida familiar i laboral. Entre les seues últimes publicacions destaquen: Cambios o continuidades en las mujeres. Un análisis sociológico, Barcelona: Icaria, (2011); «Conciliación entre la vida laboral y familiar. ¿Cuestión de género o cuestión de mujeres?» a Género y desigualdades en Iberoamérica, Argentina: Mnemosyne (2012), y «Estrategias de conciliación y segmentación social: la doble desigualdad» a Sociología. Problemas e práticas, 73, Lisboa (2013). Actualment participa en la investigació «Ciclo económico, desigualdad y polarización social» (CIEDES 2011-2014) coordinat per la Universidad Complutense de Madrid. A més, és investigadora principal del projecte «Impacte de la crisi en la transició a la vida adulta: estratègies d'emancipació de la generació perduda de Castelló».

\section{AUTORES/AUTORS}

Hedy Acosta Antognoni (hacosta@uji.es)

Forma part de l'equip d'investigació wONT - Prevenció Psicosocial (www.wont.uji.es) com a personal docent $\mathrm{i}$ investigador a temps complet a la Universitat Jaume I. És llicenciada en Psicologia amb menció en Psicologia Social i de les Organitzacions per la Universitat de Tal- 
ca, Xile (2008). Va realitzar el màster oficial en Psicologia del Treball, de les Organitzacions i en Recursos Humans en els seus dos itineraris (Salut Ocupacional i Desenvolupament de Recursos Humans) a la Universitat Jaume I. Actualment, es troba finalitzant el programa de doctorat internacional. La seua tesi doctoral versa sobre confiança organitzacional basada en el model Hero (Healthy \& Resilient Organizations) que dirigeixen la catedràtica doctora Marisa Salanova i la doctora Susana Llorens. Articles més recents: Salanova, M., Llorens, S., Acosta, H. i Torrente, P. (2013): «Positive interventions in positive organizations», Terapia Psicológica, 31, 101-113, i Acosta, H., Salanova, M. i Llorens, S. (2013): «Building Organizational Trust: A Study in Small and Medium-Sized Enterprises», a J. Neves y S. P. Gonçalves (eds.), Occupational Health Psychology: From burnout to well-being (pp. 357-378). Lisboa: Edições Sílabo.

Amparo Campos Suliano (acampos@uji.es)

Llicenciada en Psicologia per la UNED. Actualment forma part del personal d'administració i serveis de la Universitat Jaume I en el Departament de Llenguatges i Sistemes Informàtics i és la secretària de la Comissió Assessora de la Unitat d'Igualtat. Des de l'any 2010 fins al febrer del 2014 ha exercit la secretaria de la Unitat d'Igualtat de la Universitat Jaume I.

Gemma Escrig Gil (gescrig@uji.es)

Llicenciada en Dret i màster en «La mediació en la societat de la informació: nous perfils professionals d'intervenció en el segle XXI» de la Universitat Jaume I. Des de 2002 és coordinadora de Serveis Generals de la Fundació Isonomia i col·labora amb distintes organitzacions en els processos d'implantació de plans d'igualtat. Docent en distints cursos de postgrau de la Universitat Jaume I (màster univer- 
sitari en Igualtat i Gènere en l'Àmbit Públic i Privat, 2008-2013; curs de postgrau: Especialista en Agent d'Igualtat, 2009-2013, i curs de postgrau: Auditories d'Igualtat 2008-2010). Ha impartit formació presencial i en línia dirigida a empreses i organitzacions públiques, en les línies de polítiques d'igualtat, plans i mesures d'igualtat i comunicació inclusiva i no sexista (Universitat Jaume I, Ajuntament de Castelló de la Plana, Ajuntament de Benicàssim, Unión de Mutuas, etc.).

\section{SAntiago García Campa (gcampa@uji.es)}

Professor contractat doctor en el Departament de Dret del Treball i de la Seguretat Social de la Universitat Jaume I. Component de l'equip d'investigació Dret i Gènere, dirigit per la Dra. Asunción Ventura Franch. Coordinador adjunt del màster interuniversitari en Igualtat i Gènere en l'Àmbit Públic i Privat, del qual també és professor. La seua tesi doctoral va merèixer el premi del Comitè Econòmic i Social de la Comunitat Valenciana l'any 2007. Ha participat en diversos projectes d'investigació sobre polítiques d'igualtat, el més recent dirigit a conèixer els resultats de la negociació col·lectiva en matèria d'igualtat efectiva a la Comunitat Valenciana.

\section{Ana Martí Gual (marti@uji.es)}

Llicenciada en Sociologia per la Universidad Complutense de Madrid i doctora per la Universitat Jaume I. Professora de Sociologia en el Departament de Filosofia i Sociologia de la Universitat Jaume I des de l'any 1991. Al llarg de la seua experiència docent ha impartit assignatures directament relacionades amb la perspectiva de gènere tant en llicenciatura com en màster, com per exemple: Sociologia del treball de les dones, Eines per a implementar la transversalitat de gènere i Obres de referència en la investigació feminista i de gènere. Les seues principals publicacions i línies d'investigació estan així mateix relacionades 
amb el gènere, i forma part en l'actualitat de dos grups d'investigació de la Universitat Jaume I: Sociologia de la Tecnologia, Mediambiental, Urbana i del Gènere, i IO-LAB: Sistema de Relacions Laborals, Gènere i Igualtat, que estan desenvolupant els projectes «Impacte de la crisi en la transició a la vida adulta: estratègies d'emancipació de la generació perduda a la província de Castelló» i «Classificació professional i garantia de no-discriminació per raó de sexe: anàlisi intersectorial de la negociació col·lectiva a la Comunitat Valenciana. Definició de criteris i impacte retributiu, respectivament».

María José Ortí Porcar (orti@uji.es)

Llicenciada en Psicologia i màster en «La mediació en la societat de la informació: nous perfils professionals d'intervenció en el segle XXI» de la Universitat Jaume I. Des de 2002 desenvolupa la seua tasca professional com a coordinadora de l'Àrea Social de la Fundació Isonomia, impulsant la igualtat efectiva de dones i homes i la prevenció de la violència de gènere en l'àmbit municipal. Docent en el postgrau universitari «Especialista en Agent d'Igualtat». Ha participat com a docent i ponent en distints seminaris, congressos i jornades relacionats, principalment, amb les àrees de polítiques d'igualtat, gestió del temps, apoderament i prevenció de la violència de gènere.

\section{Lourdes Pascual Gargallo (lourdes.pascual@uji.es)}

Traductora i revisora. Es va llicenciar en Traducció i Interpretació. Va treballar durant sis anys en el Servei de Llengües i Terminologia de la Universitat Jaume I. A partir de novembre de 2009 s'integra en el Servici de Comunicació i Publicacions com a tècnica d'assessorament lingüístic en les tres principals llengües de comunicació científica de la Universitat: espanyol, català i anglès. S'especialitza en l'ús igualitari del llenguatge i té una dilatada experiència en la impartició de formació sobre sexisme lingüístic i en els mitjans de comunicació. 
Vicent Querol Vicente (vquerol@uji.es)

Professor de Sociologia en el Departament de Filosofia i Sociologia de la Universitat Jaume I, des de l'any 2003. És doctor per la mateixa universitat. Imparteix, entre d'altres, l'assignatura Tècniques d'Investigació Social en les titulacions Publicitat i Relacions Públiques i Relacions Laborals i Recursos Humans. Ha participat en investigacions sociològiques en diversos camps com per exemple la cultura i la llengua, les tecnologies de la informació i la comunicació, i els de la sociologia rural, de l'oci i el turisme i altres temes de sociologia del territori. Ha participat en diversos projectes en el marc de programes de la Unió Europea (Grundtvig, Intereg, Leonardo, Sòcrates, entre d'altres) que relacionaven, respectivament, el desenvolupament rural amb les TIC, l'educació en les TIC de les persones grans, les xarxes de cooperació, el turisme rural, etc. Ha publicat articles i llibres sobre aquests temes. Actualment, també és director del Projecte Estratègic de la Facultat de Ciències Humanes i Socials de la Universitat Jaume I.

Anna Sales Borx (salesa@uji.es)

Llicenciada en Filologia Anglesa i màster en Mediació per a la Igualtat d'Oportunitats en la Participació Social i en l'Ocupació, per la Universitat Jaume I. Des de 2006 és coordinadora de l'Àrea de Formació de la Fundació Isonomia. Docent en distints postgraus universitaris en matèria d'igualtat $i$ gènere de la Universitat Jaume I (curs de postgrau: Mainstreaming de gènere; curs de postgrau: Especialista en Agent d'Igualtat, i curs de postgrau: Especialista en Auditories d'Igualtat). Ha participat com a ponent en distints seminaris, congressos i jornades d'àmbit estatal relacionats, principalment, amb les àrees de coeducació, prevenció de la violència de gènere i comunicació inclusiva. 


\section{FITXA TÈCNICA}

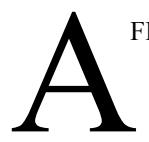

FI D'OBSERVAR la distribució de diversos fets, percepcions i opinions respecte a la qüestió de la conciliació de la vida laboral i familiar en un centre d'ensenyament superior, l'ús de l'eina de l'enquesta resulta idoni per als objectius d'aquesta investigació. En el nostre cas, s'ha optat pel qüestionari autoadministrat en línia. La coordinació de l'Oficina de la Promoció i Avaluació de la Qualitat (OPAQ) de la Universitat Jaume I i la seua familiaritat amb aquest format de treball de camp, facilitava i garantia la seua execució en aquesta investigació.

El càlcul de les distribucions mostrals ${ }^{77}$ d'aquesta investigació s'ajusta a la informació del Gabinet de Planificació i Prospectiva Tecnològica (GPPT), segons la qual, a data 28 de maig de 2013 la població de treballadors i treballadores de l'UJI era de 1.896 persones, entre personal docent i investigador (a partir d'ara, PDI) i personal d'administració i serveis (a partir d'ara, PAS); i més concretament, 1.303 persones pertanyents al PDI i 593 persones pertanyents al PAS. De forma general, l'objectiu principal és treballar amb mostres significatives en funció del tipus de treballador i treballadora de la Universitat i, per tant, es realitzarà un estudi de la mostra per separat, ja es tracte de la població de PDI o de PAS.

S'han tingut en compte, per la naturalesa de la investigació, les variables centre i sexe. En primer lloc, la variable centre servirà per a segmentar la població del PDI que es vol observar en el conjunt de la institució. En aquest sentit, la Universitat Jaume I compta amb quatre centres o facultats:

77. Aquest apartat s'elabora en estreta col-laboració amb María Teresa Mora, tècnica de l'OPAQ. 
- Escola Superior de Tecnologia i Ciències Experimentals (ESTCE)

- Facultat de Ciències Jurídiques i Econòmiques (FCJE)

- Facultat de Ciències Humanes i Socials (FCHS)

- Facultat de Ciències de la Salut (FCS)

En segon lloc, i atesa la importància per a un estudi sobre conciliació laboral i familiar, s'ha considerat la distribució desigual de la variable sexe en els diferents centres i entre els segments del PDI i PAs. D'aquesta manera, es fixa la proporcionalitat de la mostra en consonància amb la població masculina i femenina entre el PAs, així com en cada centre per al cas del PDI.

Per al conjunt del PDI, partint de la mencionada població de 1.303 subjectes, ${ }^{78} \mathrm{~s}$ 'assumeix un marge d'error d'un interval de confiança del $\pm 5 \%$, i amb un nivell de confiança del $95 \%$. La població del PDI de la Universitat Jaume I es distribueix, entre els distints centres, com segueix:

\begin{tabular}{cc} 
PDI & POBLACIÓ \\
ESTCE & 487 \\
FCJE & 274 \\
FCHS & 368 \\
FCS & 174 \\
\hline Total & $\mathbf{1 . 3 0 3}$ \\
\hline
\end{tabular}

En conseqüència, les mostres calculades per a cada centre en el col·lectiu del PDI, són les següents:

78. La diferència respecte a les dades utilitzats en el capítol 2 i que al-ludeixen a 1.329 PDI i 617 PAs se situa en el fet que aquestes últimes dades es van obtenir amb data 1 d'octubre de 2013, posteriors, doncs, a la realització de l'enquesta. 


\begin{tabular}{cc} 
PDI & MOSTRA \\
ESTCE & 111 \\
FCJE & 62 \\
FCHS & 84 \\
FCS & 40 \\
\hline Total & $\mathbf{2 9 7}$ \\
\hline
\end{tabular}

A fi de mantenir la proporcionalitat per sexe en cada centre, la distribució resultant és la següent:

\begin{tabular}{lccc}
\multicolumn{1}{c}{ PDI } & \multicolumn{2}{c}{ POBLACIÓ } & MOSTRA \\
& N & \% & \\
\hline ESTCE Homes & 333 & 25,56 & 76 \\
ESTCE Dones & 154 & 11,82 & 35 \\
FCJE Homes & 161 & 12,36 & 36 \\
FCJE Dones & 113 & 8,67 & 26 \\
FCHS Homes & 175 & 13,43 & 40 \\
FCHS Dones & 193 & 14,81 & 44 \\
FCS Homes & 66 & 5,06 & 15 \\
FCS Dones & 108 & 8,29 & 25 \\
\hline \multicolumn{1}{c}{ Total } & $\mathbf{1 . 3 0 3}$ & & $\mathbf{2 9 7}$ \\
\hline
\end{tabular}

Ens trobem amb una població de PDI molt masculinitzada, tal com obtenim en observar el conjunt del col·lectiu.

\begin{tabular}{|c|c|c|}
\hline PDI & $\mathbf{N}$ & $\%$ \\
\hline Homes & 735 & 56,4 \\
\hline Dones & 568 & 43,6 \\
\hline
\end{tabular}


Per al conjunt del PAs, partint de la mencionada població de 593 subjectes, s'assumeix un marge d'error d'un interval de confiança del $\pm 5 \%$, i amb un nivell de confiança del $95 \%$. Quant al càlcul de la grandària de la mostra de PAS es considerarà com a única variable de segmentació el sexe. La població del PAS es distribueix com segueix:

\begin{tabular}{cc}
$\boldsymbol{P A S}$ & POBLACIÓ \\
Homes & 233 \\
Dones & 360 \\
\hline Total & $\mathbf{5 9 3}$ \\
\hline
\end{tabular}

En conseqüència, les mostres calculades per al col·lectiu del pas en el conjunt de la Universitat Jaume I, i mantenint la proporcionalitat per sexe, són les següents:

\begin{tabular}{cccc}
$\boldsymbol{P A S}$ & \multicolumn{2}{c}{ POBLACIÓ } & MOSTRA \\
& $\mathbf{N}$ & $\mathbf{\%}$ & \\
Homes & 233 & 39,29 & 92 \\
Dones & 360 & 60,71 & 141 \\
\hline Total & $\mathbf{5 9 3}$ & & $\mathbf{2 3 3}$ \\
\hline
\end{tabular}

Contràriament al que ocorria amb el col-lectiu del PDI, el PAS està fortament feminitzat, ja que, a la Universitat Jaume I, 6 de cada 10 persones del PAS són dones.

Aquestes són les dades sociodemogràfiques de partida en la població i les mostres, a través de les quals s'obtindran tota una sèrie de variables socials d'importància per a la investigació.

S'han elaborat dos qüestionaris distints per al PAS i el PDI autoadministrats. El treball de camp es va realitzar entre el 8 i el 30 de juliol de 
2013. L’Oficina de la Promoció i Avaluació de la Qualitat ha coordinat el treball de camp. Durant les dates assenyalades es van realitzar tres llançaments del qüestionari més un recordatori final en els dos últims dies. En el PAS es va aconseguir exactament la mostra planificada i en el PDI es va superar aquesta xifra global $i$ es van dur a terme 317 enquestes vàlides. Aquesta mostra ens permet rebaixar el marge d'error, per a la població global del personal docent $\mathrm{i}$ investigador, $\mathrm{al} \pm 4,8 \%$.

Taula resum de la grandària i distribució de la població i la mostra

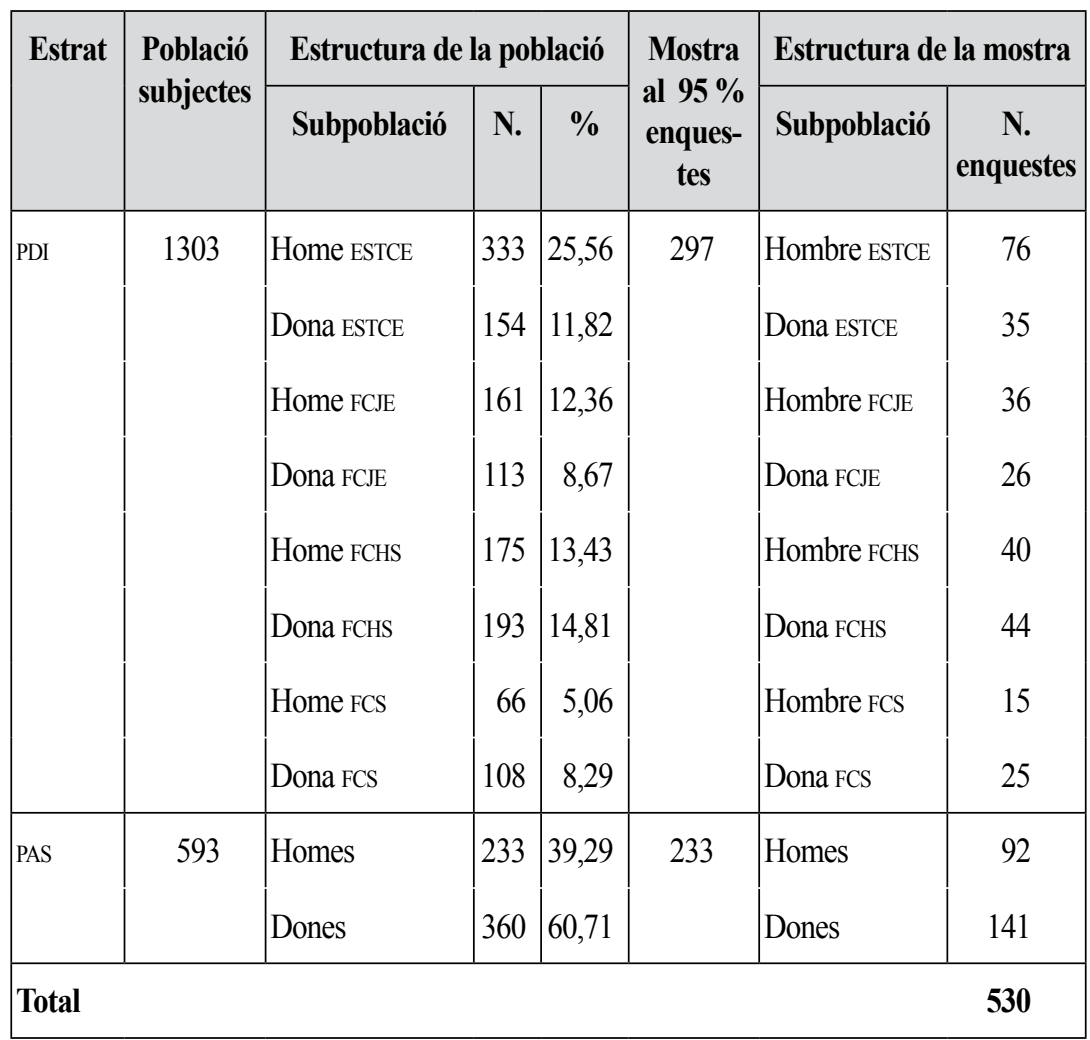




\section{QÜESTIONARIS}

\section{ENQUESTA SOBRE LA PERCEPCIÓ \\ I LES NECESSITATS DE CONCILIACIÓ \\ DE LA VIDA FAMILIAR I LABORAL DEL PAS}

'OBJECTIU D'AQUESTA ENQUESTA és conèixer la percepció i les ne-
cessitats de conciliació del personal de l'uJI.

L'enquesta té tres parts. En la primera se sol-liciten les vostres dades personals relacionades amb l'àmbit familiar i amb l'àmbit laboral; en la segona es pregunta sobre les vostres responsabilitats familiars i domèstiques; la tercera se centra en el coneixement i utilització de les mesures de conciliació de la vida familiar i laboral i en la valoració personal de les dificultats trobades en la conciliació.

Per a contestar utilitzeu l'escala de valoració que s'ofereix en cada cas i marqueu l'opció que millor s'ajuste a la vostra opinió. Per motius del sistema informàtic totes les preguntes han de ser contestades, però si no voleu donar la vostra opinió sobre qualsevol qüestió plantejada, s'ha habilitat un camp ns/nc a què podeu optar.

El temps estimat per a la realització de l'enquesta és d'uns 10 minuts.

Moltes gràcies per la vostra col·laboració. Les vostres respostes ens ajudaran a millorar la qualitat de vida de la Universitat. 


\section{DADES PERSONALS}

P1. Sexe:

P2. Edat:
Home $\square$ Dona $\square$ ns/nc $\square$

Menys de 33 anys $\square \quad$ Entre 33 i 39 años

Entre 40 i 49 anys $\square 50$ anys i més $\square \mathrm{ns} / \mathrm{nc} \square$

P3. ¿Quin és el vostre nivell màxim d'estudis finalitzat?
Primaris
$\square$
Secundaris
Diplomatura $\square$
Llicenciatura
Grau
Màster
Doctorat
$\mathrm{ns} / \mathrm{nc}$

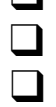

P4. Indiqueu quina es la vostra categoria laboral actual:

Grup A sense direcció $\square$ Grup A amb direcció

Grup B $\square \quad$ Grup C o D sense direcció $\square$

Grup C o D amb direcció $\square$ ns/nc $\square$

P5. Indiqueu quina és la vostra jornada laboral:

Matí (més una vesprada) $\square \quad$ Vespradra (més un matí) $\square$ Jornada partida $\square \mathrm{ns} / \mathrm{nc} \square$

P6. Generalment, quant de temps invertiu en el desplaçament des de la vostra residència habitual fins a la Universitat?
15 minuts o menys $\square$ Entre 16 i 30 minuts $\square$
Entre 31 i 45 minuts $\square$ Més de 46 minuts $\square$ $\mathrm{ns} / \mathrm{nc}$

P7. Quina és la vostra situació familiar o tipus de llar actual?

Parella amb fills/es $\square \quad$ Parella sense fills/es $\square$

Parella amb fills/es i altres familiars

Parella sense fills/es i altres familiars

Persona sola amb fills/es (si aquesta és la vostra resposta, passeu a la a la P11)

Persona sola amb altres familiars (si aquesta és la vostra resposta, passeu a la P14) $\square$

Llar unipersonal (si aquesta és la vostra resposta, passeu a la P14) $\square$ Llar compartida per persones sense vinculació familiar (si aquesta és la vostra resposta, passeu a la P14) $\square$

Altres situacions $\square \mathrm{ns} / \mathrm{nc} \square$ 
P8. Indiqueu la situació en què es troba la vostra parella actualment: Estudia (si aquesta és la vostra resposta, passeu a la P10) $\square$ Parada (si aquesta és la vostra resposta, passeu a la P10) $\square$ Jubilada/pensionista/prejubilada (si aquesta és la vostra resposta, passeu a la P10) $\square$

Tasques domèstiques ( si aquesta és la vostra resposta, passeu a la P10

Ocupada: assalariat/a, autònom/a, empresari/ària (si aquesta és la vostra resposta, passeu a la P9) $\square$ ns/nc $\square$

P9. Quina és la jornada laboral habitual de la vostra parella?

Jornada laboral contínua de matí $\square$

Jornada laboral contínua de vesprada

Jornada laboral partida $\square$

Jornada laboral a torns

Un altre tipus de jornada laboral $\square$ ns/nc $\square$

\section{RESPONSABILITATS FAMILIARS I DOMÈSTIQUES}

P10. A continuació es presenten una sèrie d'afirmacions respecte a l'exercici de tasques a la vostra llar. Penseu quina de les alternatives de resposta s'acosta més a la vostra realitat:

\begin{tabular}{|l|c|c|c|c|c|c|}
\hline & $\mathbf{1}$ & $\mathbf{2}$ & $\mathbf{3}$ & $\mathbf{4}$ & $\mathbf{5}$ & $\mathbf{n s} / \mathbf{n c}$ \\
\hline Mai & $\begin{array}{c}\text { Quasi } \\
\text { mai }\end{array}$ & $\begin{array}{c}\text { Algunes } \\
\text { vegades }\end{array}$ & $\begin{array}{c}\text { Quasi } \\
\text { sempre }\end{array}$ & Sempre & \\
\hline a) Cuine & & & & & & \\
\hline $\begin{array}{c}\text { b) Realitze les tasques de } \\
\text { neteja }\end{array}$ & & & & & & \\
\hline $\begin{array}{c}\text { c) Realitze la tasca de plan- } \\
\text { xar la roba }\end{array}$ & & & & & & \\
\hline
\end{tabular}




\begin{tabular}{|c|c|c|c|c|c|c|}
\hline & $\mathbf{1}$ & $\mathbf{2}$ & $\mathbf{3}$ & $\mathbf{4}$ & $\mathbf{5}$ & $\mathbf{n s} / \mathbf{n c}$ \\
Mai & $\begin{array}{c}\text { Quasi } \\
\text { mai }\end{array}$ & $\begin{array}{c}\text { Algunes } \\
\text { vegades }\end{array}$ & $\begin{array}{c}\text { Quasi } \\
\text { sempre }\end{array}$ & Sempre & \\
\hline $\begin{array}{c}\text { d) Realitze les reparacions } \\
\text { domèstiques (exemple: } \\
\text { reparar la cisterna del } \\
\text { wc) }\end{array}$ & & & & & & \\
\hline $\begin{array}{c}\text { e) Realitze la compra } \\
\text { setmanal }\end{array}$ & & & & & \\
\hline
\end{tabular}

P11. Teniu fills/es menors de 18 anys que viuen a la vostra llar? Sí

No (si aquesta és la vostra resposta, passeu a la P14) ns/nc

P12. Indiqueu, en cada casella, quants fills d'aqueixa edat teniu:

\begin{tabular}{|c|c|c|c|}
\hline Anys & De 0 anys & $\begin{array}{c}1,2,3,4,5,6,7,8,9,10,11 \\
12,13,14,15,16 \text { anys }\end{array}$ & De 17 anys \\
\hline \multirow[t]{6}{*}{ Fills } & $\mathrm{ns} / \mathrm{nc}$ & $\mathrm{ns} / \mathrm{nc}$ & $\mathrm{ns} / \mathrm{nc}$ \\
\hline & 1 & 1 & 1 \\
\hline & 2 & 2 & 2 \\
\hline & 3 & 3 & 3 \\
\hline & 4 & 4 & 4 \\
\hline & 5 & 5 & 5 \\
\hline
\end{tabular}


P13. A continuació es presenten una sèrie d'afirmacions respecte a la cura de fills i filles. Penseu quina de les alternatives de resposta s'acosta més a la vostra realitat:

\begin{tabular}{|c|c|c|c|c|c|c|}
\hline & $\begin{array}{c}\mathbf{1} \\
\text { Mai }\end{array}$ & $\begin{array}{c}\mathbf{2} \\
\text { Quasi } \\
\text { mai }\end{array}$ & $\begin{array}{c}\mathbf{3} \\
\text { Algunes } \\
\text { vegades }\end{array}$ & $\begin{array}{c}\mathbf{4} \\
\text { Quasi } \\
\text { sempre }\end{array}$ & $\begin{array}{c}\mathbf{5} \\
\text { Sempre }\end{array}$ & ns/nc \\
\hline $\begin{array}{c}\text { a) Acompanye els meus } \\
\text { fills/es menors } \\
\text { al col·legi }\end{array}$ & & & & & & \\
\hline $\begin{array}{c}\text { b) Assistisc a reunions } \\
\text { amb tutors/es o docents } \\
\text { dels meus fills/es }\end{array}$ & & & & & & \\
\hline $\begin{array}{c}\text { c) Done suport als meus } \\
\text { fills/es en les seues } \\
\text { tasques escolars }\end{array}$ & & & & & & \\
\hline $\begin{array}{c}\text { d) } \text { Supervise la higiene } \\
\text { dels meus fills/es per a } \\
\text { assistir al col-legi }\end{array}$ & & & & & & \\
\hline $\begin{array}{c}\text { e) Porte els meus fills/es } \\
\text { a les assistències i re- } \\
\text { visions mèdiques }\end{array}$ & & & & & & \\
\hline
\end{tabular}

P14. Teniu familiars en situació de dependència a càrrec vostre (persones ancianes, amb discapacitat o familiars amb una malaltia greu)?

Sí $\square$

No (si aquesta és la vostra resposta, passeu a la P16)

ns/nc

Indiqueu el nombre de persones a càrrec vostre: 
P15. A continuació es presenten una sèrie d'afirmacions respecte a les persones grans o en situació de dependència (que convisquen o no amb vós). Penseu quina de les alternatives de resposta s'acosta més a la vostra realitat:

\begin{tabular}{|c|c|c|c|c|c|c|}
\hline & $\begin{array}{c}\mathbf{1} \\
\text { Mai }\end{array}$ & $\begin{array}{c}\mathbf{2} \\
\text { Quasi } \\
\text { mai }\end{array}$ & $\begin{array}{c}\mathbf{3} \\
\text { Algunes } \\
\text { vegades }\end{array}$ & $\begin{array}{c}\mathbf{4} \\
\text { Quasi } \\
\text { sempre }\end{array}$ & $\begin{array}{c}\mathbf{5} \\
\text { Sempre }\end{array}$ & $\mathbf{n s / n c}$ \\
\hline $\begin{array}{r}\text { a) Acompanye els meus } \\
\text { familiars grans o perso- } \\
\text { nes en situació de de- } \\
\text { pendència a revisions } \\
\text { mèdiques }\end{array}$ & & & & & \\
\hline $\begin{array}{c}\text { b) Controle la medicació } \\
\text { de familiars grans o per- } \\
\text { sones dependents }\end{array}$ & & & & & & \\
\hline $\begin{array}{c}\text { c) Supervise la higiene per- } \\
\text { sonal dels meus fami- } \\
\text { liars grans o persones } \\
\text { dependents }\end{array}$ & & & & & & \\
\hline
\end{tabular}

CONEIXEMENT I UTILITZACIÓ DE LES MESURES PER A LA CONCILIACIÓ DE LA VIDA FAMILIAR I LABORAL

P16. Coneixeu la legislació en matèria de conciliació?

Sí $\square \quad$ No $\square$ ns/nc $\square$

P17. Coneixeu el Pla d'Igualtat de l'usi?

Sí $\square \quad$ No $\square$ ns/nc $\square$ 
P18. De les següents mesures relacionades amb la conciliació vida laboral/vida familiar, quines en coneixeu i quines n'heu utilitzat?

\begin{tabular}{|c|c|c|}
\hline & $\begin{array}{l}\text { 1. Coneixeu } \\
\text { la mesura? }\end{array}$ & $\begin{array}{l}\text { 2. La utilitzeu o } \\
\text { l'heu utilitzada? }\end{array}$ \\
\hline $\begin{array}{l}\text { a) Preferència en accés als cursos de for- } \\
\text { mació del PAS }\end{array}$ & $\begin{array}{c}\text { Sí } \\
\text { No } \\
\text { ns/nc }\end{array}$ & $\begin{array}{c}\text { Sí } \\
\text { No } \\
\mathrm{ns} / \mathrm{nc}\end{array}$ \\
\hline $\begin{array}{l}\text { b) Permís per a visites mèdiques i assis- } \\
\text { tència a persones menors, ancianes i } \\
\text { amb discapacitat. }\end{array}$ & $\begin{array}{c}\text { Sí } \\
\text { No } \\
\text { ns/nc }\end{array}$ & $\begin{array}{c}\text { Sí } \\
\text { No } \\
\text { ns/nc }\end{array}$ \\
\hline $\begin{array}{l}\text { c) Permís de maternitat/paternitat o per- } \\
\text { mís d'adopció o acolliment }\end{array}$ & $\begin{array}{c}\text { Sí } \\
\text { No } \\
\text { ns/nc }\end{array}$ & $\begin{array}{c}\text { Sí } \\
\text { No } \\
\text { ns/nc }\end{array}$ \\
\hline $\begin{array}{l}\text { d) Permís de lactància o acumulació d'ho- } \\
\text { res de lactància }\end{array}$ & $\begin{array}{c}\text { Sí } \\
\text { No } \\
\text { ns/nc }\end{array}$ & $\begin{array}{c}\text { Sí } \\
\text { No } \\
\text { ns/nc }\end{array}$ \\
\hline $\begin{array}{l}\text { e) Permís per intervenció quirúrgica de } \\
\text { familiars o malaltia greu de familiar }\end{array}$ & $\begin{array}{c}\text { Sí } \\
\text { No } \\
\text { ns/nc }\end{array}$ & $\begin{array}{c}\text { Sí } \\
\text { No } \\
\text { ns/nc }\end{array}$ \\
\hline $\begin{array}{l}\text { f) Adaptació/reducció de la jornada de } \\
\text { treball per raó d'atenció a menors de } \\
\text { fins a } 12 \text { anys }\end{array}$ & $\begin{array}{c}\text { Sí } \\
\text { No } \\
\text { ns/nc }\end{array}$ & $\begin{array}{c}\text { Sí } \\
\text { No } \\
\text { ns/nc }\end{array}$ \\
\hline $\begin{array}{l}\text { g) Adaptació/reducció de la jornada de } \\
\text { treball per raó de convivència amb } \\
\text { l'atenció directa a una persona amb dis- } \\
\text { capacitat física, psíquica o sensorial. }\end{array}$ & $\begin{array}{c}\text { Sí } \\
\text { No } \\
\text { ns/nc }\end{array}$ & $\begin{array}{c}\text { Sí } \\
\text { No } \\
\text { ns/nc }\end{array}$ \\
\hline $\begin{array}{l}\text { h) Adaptació/reducció de la jornada de } \\
\text { treball per raó d'atenció directa a fami- } \\
\text { liars fins al segon grau de consangui- } \\
\text { nitat o afinitat, que per raó d'edat, ac- } \\
\text { cident o malaltia no puga valdre's per } \\
\text { si mateix i no exercisca activitat retri- } \\
\text { buïda }\end{array}$ & $\begin{array}{c}\text { Sí } \\
\text { No } \\
\text { ns/nc }\end{array}$ & $\begin{array}{c}\text { Sí } \\
\text { No } \\
\text { ns/nc }\end{array}$ \\
\hline
\end{tabular}




\begin{tabular}{|c|c|c|}
\hline & $\begin{array}{l}\text { 1. Coneixeu } \\
\text { la mesura? }\end{array}$ & $\begin{array}{l}\text { 2. La utilitzeu o } \\
\text { l'heu utilitzada? }\end{array}$ \\
\hline $\begin{array}{l}\text { i) Adaptació/reducció de la jornada de } \\
\text { treball per raó d'atenció a fill o filla me- } \\
\text { nor afectada per càncer o una altra ma- } \\
\text { laltia greu que implique un ingrés hos- } \\
\text { pitalari de llarga duració }\end{array}$ & $\begin{array}{c}\text { Sí } \\
\text { No } \\
\text { ns/nc }\end{array}$ & $\begin{array}{c}\text { Sí } \\
\text { No } \\
\text { ns/nc }\end{array}$ \\
\hline $\begin{array}{l}\text { j) Reducció de la jornada de treball per } \\
\text { raó de malaltia llarga o crònica que im- } \\
\text { pedisca realitzar la jornada laboral com- } \\
\text { pleta }\end{array}$ & $\begin{array}{c}\text { Sí } \\
\text { No } \\
\text { ns/nc }\end{array}$ & $\begin{array}{c}\text { Sí } \\
\text { No } \\
\text { ns/nc }\end{array}$ \\
\hline $\begin{array}{l}\text { k) Flexibilitat horària en la jornada de } \\
\text { treball per raó de guarda legal de me- } \\
\text { nors o familiars que requerisquen de- } \\
\text { dicació especial }\end{array}$ & $\begin{array}{c}\text { Sí } \\
\text { No } \\
\text { ns/nc }\end{array}$ & $\begin{array}{c}\text { Sí } \\
\text { No } \\
\text { ns/nc }\end{array}$ \\
\hline $\begin{array}{l}\text { l) Excedència per atenció a menors o fa- } \\
\text { miliars a càrrec }\end{array}$ & $\begin{array}{c}\text { Sí } \\
\text { No } \\
\text { ns/nc }\end{array}$ & $\begin{array}{c}\text { Sí } \\
\text { No } \\
\text { ns/nc }\end{array}$ \\
\hline $\begin{array}{l}\text { m) Reducció/permís/excedència per raó } \\
\text { de violència de gènere }\end{array}$ & $\begin{array}{c}\text { Sí } \\
\text { No } \\
\text { ns/nc }\end{array}$ & $\begin{array}{c}\text { Sí } \\
\text { No } \\
\text { ns/nc }\end{array}$ \\
\hline
\end{tabular}

\section{P19. Identifiqueu els dos principals motius pels quals no heu uti- litzat les mesures anteriors:}

No les he necessitades fins ara

Desconeixia que existien $\square$

No puc prescindir de part o del total del meu sou

Afectaria negativament la meua carrera professional $\mathrm{ns} / \mathrm{nc}$ 
P20. Quines altres mesures considereu que es podrien implantar a la Universitat?

P21. En el vostre cas particular, la conciliació entre la vida familiar i la vida laboral us resulta...:

Molt complicada $\square$ Complicada $\square$ Senzilla $\square$

Muy senzilla $\square \mathrm{ns} / \mathrm{nc}$

P22. A continuació es presenten una sèrie d'afirmacions respecte a la conciliació de la vida laboral i familiar. Penseu quina de les alternatives de resposta reflecteix més la vostra opinió:

\begin{tabular}{|c|c|c|c|c|c|c|}
\hline & $\begin{array}{c}1 \\
\text { CED }\end{array}$ & $\begin{array}{c}2 \\
\text { AED }\end{array}$ & $\begin{array}{l}3 \\
\text { I }\end{array}$ & $\begin{array}{c}\mathbf{4} \\
\text { ADA }\end{array}$ & $\begin{array}{c}5 \\
\text { CDA }\end{array}$ & ns $/ \mathbf{n c}$ \\
\hline $\begin{array}{l}\text { a) Considere que les responsa- } \\
\text { bilitats domèstiques estan } \\
\text { repartides equilibradament } \\
\text { amb la meua parella }\end{array}$ & & & & & & \\
\hline $\begin{array}{l}\text { b) Considere que l'atenció als } \\
\text { fills/es està repartida equilibra- } \\
\text { dament amb la meua parella }\end{array}$ & & & & & & \\
\hline $\begin{array}{l}\text { c) Considere que repartisc de } \\
\text { forma equilibrada el temps } \\
\text { que dedique a les meues ne- } \\
\text { cessitats personals, familiars } \\
\text { i laborals }\end{array}$ & & & & & & \\
\hline $\begin{array}{l}\text { d) La meua parella percep que } \\
\text { compartim les tasques do- } \\
\text { mèstiques }\end{array}$ & & & & & & \\
\hline
\end{tabular}




\begin{tabular}{|c|c|c|c|c|c|c|}
\hline & $\begin{array}{c}1 \\
\text { CED }^{79}\end{array}$ & $\begin{array}{c}2 \\
\text { AED }\end{array}$ & $\begin{array}{l}3 \\
\text { I }\end{array}$ & $\begin{array}{c}4 \\
\mathrm{ADA}\end{array}$ & $\begin{array}{c}5 \\
\text { CDA }\end{array}$ & ns/nc \\
\hline $\begin{array}{l}\text { e) La meua parella percep que } \\
\text { compartim les responsabili- } \\
\text { tats familiars }\end{array}$ & & & & & & \\
\hline $\begin{array}{l}\text { f) Per a realitzar les tasques do- } \\
\text { mèstiques comptem amb una } \\
\text { persona externa }\end{array}$ & & & & & & \\
\hline $\begin{array}{l}\text { g) Per a les tasques d'atenció a } \\
\text { fills/es comptem amb una } \\
\text { persona externa }\end{array}$ & & & & & & \\
\hline $\begin{array}{l}\text { h) Per a les tasques d'atenció a } \\
\text { familiars majors o en situació } \\
\text { de dependència comptem } \\
\text { amb una persona externa }\end{array}$ & & & & & & \\
\hline
\end{tabular}

79. $\quad \mathrm{CED}=$ completament en desacord $\mathrm{AED}=$ un poc en desacord

$\mathrm{I}=$ indiferent

$\mathrm{ADA}=$ un poc d'acord

$\mathrm{CDA}=$ completament d'acord 
P23. Per a finalitzar, indiqueu quin percentatge, del $100 \%$ del vostre temps setmanal, dediqueu a:

\begin{tabular}{|c|c|c|c|}
\hline & $\begin{array}{c}\text { Necessitats } \\
\text { personals }\end{array}$ & $\begin{array}{l}\text { Necessitats } \\
\text { familiars }\end{array}$ & $\begin{array}{c}\text { Necessitats } \\
\text { laborals }\end{array}$ \\
\hline \multirow{12}{*}{$\begin{array}{l}\text { Percentatge de } \\
\text { temps }\end{array}$} & $\mathrm{ns} / \mathrm{nc}$ & $\mathrm{ns} / \mathrm{nc}$ & $\mathrm{ns} / \mathrm{nc}$ \\
\hline & $0 \%$ & $0 \%$ & $0 \%$ \\
\hline & $10 \%$ & $10 \%$ & $10 \%$ \\
\hline & $20 \%$ & $20 \%$ & $20 \%$ \\
\hline & $30 \%$ & $30 \%$ & $30 \%$ \\
\hline & $40 \%$ & $40 \%$ & $40 \%$ \\
\hline & $50 \%$ & $50 \%$ & $50 \%$ \\
\hline & $60 \%$ & $60 \%$ & $60 \%$ \\
\hline & $70 \%$ & $70 \%$ & $70 \%$ \\
\hline & $80 \%$ & $80 \%$ & $80 \%$ \\
\hline & $90 \%$ & $90 \%$ & $90 \%$ \\
\hline & $100 \%$ & $100 \%$ & $100 \%$ \\
\hline
\end{tabular}




\section{ENQUESTA SOBRE LA PERCEPCIÓ I LES NECESSITATS DE CONCILIACIÓ DE LA VIDA FAMILIAR I LABORAL DEL PDI}

L'objectiu d'aquesta enquesta és conèixer la percepció i les necessitats de conciliació del personal de l'uJI.

L'enquesta té tres parts. En la primera se sol-liciten les vostres dades personals relacionades amb l'àmbit familiar i amb l'àmbit laboral; en la segona es pregunta sobre les vostres responsabilitats familiars $i$ domèstiques; la tercera se centra en el coneixement i utilització de les mesures de conciliació de la vida familiar i laboral i en la valoració personal de les dificultats trobades en la conciliació.

Per a contestar utilitzeu l'escala de valoració que s'ofereix en cada cas i marqueu l'opció que millor s'ajuste a la vostra opinió. Per motius del sistema informàtic totes les preguntes han de ser contestades, però si no voleu donar la vostra opinió sobre qualsevol qüestió plantejada, s'ha habilitat un camp ns/nc a què podeu optar.

El temps estimat per a la realització de l'enquesta és d'uns 10 minuts.

Moltes gràcies per la vostra col·laboració. Les vostres respostes ens ajudaran a millorar la qualitat de vida de la Universitat.

\section{DADES PERSONALS}

\section{P1. Sexe:}

Home $\square$ Dona $\square$ ns/nc $\square$

\section{P2. Edat:}

Menys de 33 anys $\square \quad$ Entre 33 i 39 anys $\square$

Entre 40 i 49 anys $\square 50$ anys i més $\square$ ns/nc $\square$ 
P3. Quin és el vostre nivell màxim d'estudis finalitzat?

$\begin{array}{llllll}\text { Primaris } & \square & \text { Secundaris } & \square & \text { Diplomatura } & \square \\ \text { Licenciatura } & \square & \text { Grau } & \square & \text { Màster } & \square \\ \text { Doctorat } & \square & \text { ns/nc } & \square & & \end{array}$

P4. Indiqueu quina és la vostra categoria laboral actual:

Catedràtic/a $\square$ Titular d'universitat $\square$

Catedràtic/a d'escola $\square$ Titular d'escola $\square$

Contractat/da doctor/a $\square$ Professor/a colllaborador/a $\square$

Ajudant doctor/a $\square$ Ajudant/a $\square$

Personal investigador contractat/ada doctor/a $\square$

Un altre personal investigador $\square$ Professor/a associat/ada $\square$

Personal becari $\square \mathrm{ns} / \mathrm{nc} \square$

P5. En el moment actual, ocupeu algun càrrec de gestió?

Sí $\square$ No $\square \mathrm{ns} / \mathrm{nc} \square$

P6. Si pertanyeu al PDI, indiqueu en quina franja horària exerciu la docència en el curs actual:

Entre les $8 \mathrm{i}$ les 15 hores $\square \quad$ Entre les $15 \mathrm{i}$ les 21 hores $\square$

Entre les 8 i les 21 hores $\square$ ns/nc $\square$

P7. Si pertanyeu al personal becari, indiqueu en quina franja horària exerciu la vostra activitat:

Entre les $8 \mathrm{i}$ les 15 hores $\square \quad$ Entre les $15 \mathrm{i}$ les 21 hores $\square$ Entre les 8 i les 21 hores $\square$ ns/nc $\square$

P8. Generalment, quant de temps invertiu en el desplaçament des de la vostra residència habitual fins a la Universitat?

15 minuts o menys $\square$ Entre 16 i 30 minuts $\square$

Entre 31 i 45 minuts $\square$ Més de 46 minuts $\square$ $\mathrm{ns} / \mathrm{nc} \square$ 


\section{P9. Quina és la vostra situació familiar o tipus de llar actual?}

Parella amb fills/es (si aquesta és la vostra resposta, passeu a la P10) $\square$

Parella sense fills/es (si aquesta és la vostra resposta, passeu a la P10) $\square$

Parella amb fills/es i altres familiars (si aquesta és la vostra resposta, passeu a la P10) $\square$

Parella sense fills/es i altres familiars (si aquesta és la vostra resposta, passeu a la P10) $\square$

Persona sola amb fills/es (si aquesta és la vostra resposta, passeu a la P13)

Persona sola amb altres familiars (si aquesta és la vostra resposta, passeu a la P16) $\square$

Llar unipersonal (si aquesta és la vostra resposta, passeu a la P16) $\square$ Llar compartida per persones sense vinculació familiar (si aquesta és la vostra resposta, passeu a la P16)

Altres situacions $\square \mathrm{ns} / \mathrm{nc} \square$

\section{P10. Indiqueu la situació en què es troba la vostra parella actualment:}

Estudia (si aquesta és la vostra resposta, passeu a la P12) $\square$

Parada (si aquesta és la vostra resposta, passeu a la P12) $\square$

Jubilada/pensionista/prejubilada (si aquesta és la vostra resposta, passeu a la P12) $\square$

Tasques domèstiques (si aquesta és la vostra resposta, passeu a la P12) $\square$

Ocupada: assalariat/a, autònom/a, empresari/ària (si aquesta és la vostra resposta, passeu a la P11) $\square \mathrm{ns} / \mathrm{nc} \quad \square$

\section{P11. Quina és la jornada laboral habitual de la vostra parella?} Jornada laboral contínua de matí $\square$

Jornada laboral contínua de vesprada $\square$

Jornada laboral partida

Jornada laboral a torns

Un altre tipus de jornada laboral $\square \quad$ ns/nc $\square$ 


\section{RESPONSABILITATS FAMILIARS I DOMÈSTIQUES}

P12. A continuació es presenten una sèrie d'afirmacions respecte a l'exercici de tasques a la vostra llar. Penseu quina de les alternatives de resposta s'acosta més a la vostra realitat:

\begin{tabular}{|l|l|c|c|c|c|c|}
\hline & $\begin{array}{c}\mathbf{1} \\
\text { Mai }\end{array}$ & $\begin{array}{c}\mathbf{2} \\
\text { Quasi } \\
\text { mai }\end{array}$ & $\begin{array}{c}\mathbf{3} \\
\text { Algunes } \\
\text { vegades }\end{array}$ & $\begin{array}{c}\mathbf{4} \\
\text { Quasi } \\
\text { sempre }\end{array}$ & $\begin{array}{c}\mathbf{5} \\
\text { Sempre }\end{array}$ & ns/nc \\
\hline a) Cuine & & & & & & \\
\hline $\begin{array}{c}\text { b) Realitze les tasques de } \\
\text { neteja }\end{array}$ & & & & & & \\
\hline $\begin{array}{c}\text { c) Realitze la tasca de plan- } \\
\text { xar la roba }\end{array}$ & & & & & & \\
\hline $\begin{array}{c}\text { d) Realitze les reparacions } \\
\text { domèstiques (exemple: } \\
\text { reparar la cisterna del } \\
\text { wc) }\end{array}$ & & & & & & \\
\hline $\begin{array}{c}\text { e) Realitze la compra set- } \\
\text { manal }\end{array}$ & & & & & & \\
\hline
\end{tabular}

P13. Teniu fills/es menors de 18 anys que viuen a la vostra llar? Sí (si aquesta és la vostra resposta, passeu a la P14) No (si aquesta és la vostra resposta, passeu a la P16) $\mathrm{ns} / \mathrm{nc}$ 
P14. Indiqueu, en cada casella, quants fills de cada edat teniu:

\begin{tabular}{|c|c|c|c|}
\hline Anys & De 0 anys & $\begin{array}{l}1,2,3,4,5,6,7,8,9,10 \\
11,12,13,14,15,16 \text { anys }\end{array}$ & De 17 anys \\
\hline \multirow[t]{6}{*}{ Fills } & $\mathrm{ns} / \mathrm{nc}$ & $\mathrm{ns} / \mathrm{nc}$ & $\mathrm{ns} / \mathrm{nc}$ \\
\hline & 1 & 1 & 1 \\
\hline & 2 & 2 & 2 \\
\hline & 3 & 3 & 3 \\
\hline & 4 & 4 & 4 \\
\hline & 5 & 5 & 5 \\
\hline
\end{tabular}

P15. A continuació es presenten una sèrie d'afirmacions respecte a la cura de fills i filles. Penseu quina de les alternatives de resposta s'acosta més a la vostra realitat:

\begin{tabular}{|c|c|c|c|c|c|c|}
\hline & $\begin{array}{c}\mathbf{1} \\
\text { Mai }\end{array}$ & $\begin{array}{c}\mathbf{2} \\
\text { Quasi } \\
\text { mai }\end{array}$ & $\begin{array}{c}\mathbf{3} \\
\text { Algunes } \\
\text { vegades }\end{array}$ & $\begin{array}{c}4 \\
\text { Quasi } \\
\text { sempre }\end{array}$ & $\begin{array}{c}\mathbf{5} \\
\text { Sempre }\end{array}$ & ns/nc \\
\hline $\begin{array}{c}\text { a) Acompanye els meus } \\
\text { fills/es menors al col- } \\
\text { legi }\end{array}$ & & & & & & \\
\hline $\begin{array}{c}\text { b) Assistisc a reunions } \\
\text { amb tutors/es o docents } \\
\text { dels meus fills/es }\end{array}$ & & & & & & \\
\hline $\begin{array}{c}\text { c) Done suport als meus } \\
\text { fills/es en les seues tas- } \\
\text { ques escolars }\end{array}$ & & & & & & \\
\hline
\end{tabular}




\begin{tabular}{|c|c|c|c|c|c|c|}
\hline & $\begin{array}{c}\mathbf{1} \\
\text { Mai }\end{array}$ & $\begin{array}{c}\mathbf{2} \\
\text { Quasi } \\
\text { mai }\end{array}$ & $\begin{array}{c}\mathbf{3} \\
\text { Algunes } \\
\text { vegades }\end{array}$ & $\begin{array}{c}\mathbf{4} \\
\text { Quasi } \\
\text { sempre }\end{array}$ & $\begin{array}{c}\mathbf{5} \\
\text { Sempre }\end{array}$ & ns/nc \\
\hline $\begin{array}{c}\text { d) Supervise la higiene } \\
\text { dels meus fills/es per a } \\
\text { assistir al col-legi }\end{array}$ & & & & & & \\
\hline $\begin{array}{c}\text { e) Porte els meus fills/es } \\
\text { a les assistències i re- } \\
\text { visions mèdiques }\end{array}$ & & & & & & \\
\hline
\end{tabular}

P16. Teniu familiars en situació de dependència a càrrec vostre (persones ancianes, amb discapacitat o familiars amb una malaltia greu)?

Sí $\square$

No (si aquesta és la vostra resposta passeu a la P18) $\square$

ns/nc $\square$

Indiqueu el nombre de persones a càrrec vostre:

P17. A continuació es presenten una sèrie d'afirmacions respecte a les persones grans o en situació de dependència (que convisquen o no amb vós). Penseu quina de les alternatives de resposta s'acosta més a la vostra realitat:

\begin{tabular}{|c|c|c|c|c|c|c|}
\hline & $\begin{array}{c}\mathbf{1} \\
\text { Mai }\end{array}$ & $\begin{array}{c}\mathbf{2} \\
\text { Quasi } \\
\text { mai }\end{array}$ & $\begin{array}{c}\mathbf{3} \\
\text { Algunes } \\
\text { vegades }\end{array}$ & $\begin{array}{c}\mathbf{4} \\
\text { Quasi } \\
\text { sempre }\end{array}$ & $\begin{array}{c}\mathbf{5} \\
\text { Sempre }\end{array}$ & ns/nc \\
\hline $\begin{array}{c}\text { a) Acompanye els } \\
\text { meus familiars } \\
\text { grans o persones en } \\
\text { situació de depen- } \\
\text { dència a revisions } \\
\text { mèdiques }\end{array}$ & & & & & \\
\hline
\end{tabular}




\begin{tabular}{|c|c|c|c|c|c|c|}
\hline & $\begin{array}{c}\mathbf{1} \\
\text { Mai }\end{array}$ & $\begin{array}{c}\mathbf{2} \\
\text { Quasi } \\
\text { mai }\end{array}$ & $\begin{array}{c}\mathbf{3} \\
\text { Algunes } \\
\text { vegades }\end{array}$ & $\begin{array}{c}\mathbf{4} \\
\text { Quasi } \\
\text { sempre }\end{array}$ & $\begin{array}{c}\mathbf{5} \\
\text { Sempre }\end{array}$ & ns/nc \\
\hline $\begin{array}{c}\text { b) Controle la medi- } \\
\text { cació de familiars } \\
\text { grans o persones } \\
\text { dependents }\end{array}$ & & & & & & \\
\hline $\begin{array}{c}\text { c) Supervise la higiene } \\
\text { personal dels meus } \\
\text { familiars grans o } \\
\text { persones depen- } \\
\text { dents }\end{array}$ & & & & & & \\
\hline
\end{tabular}

\section{CONEIXEMENT I UTILITZACIÓ DE LES MESURES PER A LA CONCILIACIÓ DE LA VIDA FAMILIAR I LABORAL}

\section{P18. Coneixeu la legislació en matèria de conciliació?}

Sí $\square$ No $\square$ ns/nc $\square$

P19. Coneixeu el I Pla d'Igualtat de l'usi?

Sí $\square$ No $\square \mathrm{ns} / \mathrm{nc} \square$

P20. De les següents mesures relacionades amb la conciliació vida laboral/vida familiar, quines en coneixeu i quines n'heu utilitzat?

\begin{tabular}{|l|c|c|}
\hline & $\begin{array}{c}\text { 1. Coneixeu } \\
\text { la mesura? }\end{array}$ & $\begin{array}{c}\text { 2. La utilitzeu o } \\
\text { l'heu utilitzada? }\end{array}$ \\
\hline $\begin{array}{l}\text { a) Preferència en elecció d'horaris lectius } \\
\text { del PDI }\end{array}$ & $\mathrm{Sí}$ & $\mathrm{Sí}$ \\
& $\mathrm{No}$ & $\mathrm{No}$ \\
$\mathrm{ns} / \mathrm{nc}$ & $\mathrm{ns} / \mathrm{nc}$ \\
\hline b) Permís per a visites mèdiques i assistència & $\mathrm{Sí}$ & $\mathrm{Sí}$ \\
a persones menors, ancianes i amb disca- & $\mathrm{No}$ & $\mathrm{No}$ \\
pacitat & $\mathrm{ns} / \mathrm{nc}$ & $\mathrm{ns} / \mathrm{nc}$ \\
\hline
\end{tabular}




\begin{tabular}{|c|c|c|}
\hline & $\begin{array}{l}\text { 1. Coneixeu } \\
\text { la mesura? }\end{array}$ & $\begin{array}{l}\text { 2. La utilitzeu o } \\
\text { l'heu utilitzada? }\end{array}$ \\
\hline $\begin{array}{l}\text { c) Permís de maternitat/paternitat o permís } \\
\text { d'adopció o acolliment }\end{array}$ & $\begin{array}{c}\text { Sí } \\
\text { No } \\
\text { ns/nc }\end{array}$ & $\begin{array}{c}\text { Sí } \\
\text { No } \\
\text { ns/nc }\end{array}$ \\
\hline $\begin{array}{l}\text { d) Permís de lactància o acumulació d'hores } \\
\text { de lactància }\end{array}$ & $\begin{array}{c}\text { Sí } \\
\text { No } \\
\text { ns/nc }\end{array}$ & $\begin{array}{c}\text { Sí } \\
\text { No } \\
\text { ns/nc }\end{array}$ \\
\hline $\begin{array}{l}\text { e) Permís per intervenció quirúrgica de fa- } \\
\text { miliars o malaltia greu de familiar }\end{array}$ & $\begin{array}{c}\text { Sí } \\
\text { No } \\
\text { ns/nc }\end{array}$ & $\begin{array}{c}\text { Sí } \\
\text { No } \\
\text { ns/nc }\end{array}$ \\
\hline $\begin{array}{l}\text { f) Adaptació/reducció de la jornada de treball } \\
\text { per raó d'atenció a menors de fins a } 12 \\
\text { anys }\end{array}$ & $\begin{array}{c}\text { Sí } \\
\text { No } \\
\text { ns/nc }\end{array}$ & $\begin{array}{c}\text { Sí } \\
\text { No } \\
\text { ns/nc }\end{array}$ \\
\hline $\begin{array}{l}\text { g) Adaptació/reducció de la jornada de tre- } \\
\text { ball per raó de convivència amb l'atenció } \\
\text { directa a una persona amb discapacitat } \\
\text { física, psíquica o sensorial }\end{array}$ & $\begin{array}{c}\text { Sí } \\
\text { No } \\
\text { ns/nc }\end{array}$ & $\begin{array}{c}\text { Sí } \\
\text { No } \\
\text { ns/nc }\end{array}$ \\
\hline $\begin{array}{l}\text { h) Adaptació/reducció de la jornada de tre- } \\
\text { ball per raó d'atenció directa a familiars } \\
\text { fins al segon grau de consanguinitat o afi- } \\
\text { nitat, que per raó d'edat, accident o ma- } \\
\text { laltia no puga valdre's per si mateix i no } \\
\text { exercisca activitat retribuïda }\end{array}$ & $\begin{array}{c}\text { Sí } \\
\text { No } \\
\text { ns/nc }\end{array}$ & $\begin{array}{c}\text { Sí } \\
\text { No } \\
\text { ns/nc }\end{array}$ \\
\hline $\begin{array}{l}\text { i) Adaptació/reducció de la jornada de treball } \\
\text { per raó d'atenció a fill o filla menor afec- } \\
\text { tada per càncer o una altra malaltia greu } \\
\text { que implique un ingrés hospitalari de llar- } \\
\text { ga duració }\end{array}$ & $\begin{array}{c}\text { Sí } \\
\text { No } \\
\text { ns/nc }\end{array}$ & $\begin{array}{c}\text { Sí } \\
\text { No } \\
\mathrm{ns} / \mathrm{nc}\end{array}$ \\
\hline $\begin{array}{l}\text { j) Reducció de la jornada de treball per raó } \\
\text { de malaltia llarga o crònica que impedisca } \\
\text { realitzar la jornada laboral completa }\end{array}$ & $\begin{array}{c}\text { Sí } \\
\text { No } \\
\text { ns/nc }\end{array}$ & $\begin{array}{c}\text { Sí } \\
\text { No } \\
\text { ns/nc }\end{array}$ \\
\hline
\end{tabular}




\begin{tabular}{|c|c|c|}
\hline & $\begin{array}{c}\text { 1. Coneixeu } \\
\text { la mesura? }\end{array}$ & $\begin{array}{c}\text { 2. La utilitzeu o } \\
\text { l'heu utilitzada? }\end{array}$ \\
\hline $\begin{array}{r}\text { k) Flexibilitat horària en la jornada de treball } \\
\text { per raó de guarda legal de menors o fami- }\end{array}$ & $\mathrm{Sí}$ & $\mathrm{So}$ \\
liars que requerisquen dedicació especial & $\mathrm{ns} / \mathrm{nc}$ & $\mathrm{No}$ \\
\hline \multirow{2}{*}{ Excedència per atenció a menors o fami- } & $\mathrm{Sí}$ & $\mathrm{ns} / \mathrm{nc}$ \\
liars a càrrec vostre & $\mathrm{No}$ & $\mathrm{No}$ \\
& $\mathrm{ns} / \mathrm{nc}$ & $\mathrm{ns} / \mathrm{nc}$ \\
\hline \multirow{2}{*}{ Reducció/permís/excedència per raó de } & Sí & Sí \\
violència de gènere & No & No \\
& $\mathrm{ns} / \mathrm{nc}$ & $\mathrm{ns} / \mathrm{nc}$ \\
\hline
\end{tabular}

P21. Identifiqueu els dos principals motius pels quals no heu utilitzat les mesures anteriors:

No les he necessitades fins ara

Desconeixia que existien $\square$

No puc prescindir de part o del total del meu sou $\square$

Afectaria negativament la meua carrera professional

$\mathrm{ns} / \mathrm{nc} \square$

P22. Quines altres mesures considereu que es podrien implantar a la Universitat?

P23. En el vostre cas particular, la conciliació entre la vida familiar i la vida laboral us resulta...:

$\begin{array}{llllll}\text { Molt complicada } & \square & \text { Complicada } & \square & \text { Senzilla } \square \\ \text { Molt Senzilla } & \square & \text { ns/nc } & \square & & \end{array}$ 
P24. A continuació es presenten una sèrie d'afirmacions respecte a la conciliació de la vida laboral i familiar. Penseu quina de les alternatives de resposta reflecteix més la vostra opinió:

\begin{tabular}{|c|c|c|c|c|c|c|}
\hline & $\begin{array}{c}\mathbf{1}^{*} \\
\text { CED }\end{array}$ & $\begin{array}{c}2 \\
\text { AED }\end{array}$ & $\begin{array}{l}3 \\
\text { I }\end{array}$ & $\begin{array}{c}4 \\
\text { ADA }\end{array}$ & $\begin{array}{c}5 \\
\text { CDA }\end{array}$ & ns/nc \\
\hline $\begin{array}{l}\text { a) Considere que les respon- } \\
\text { sabilitats domèstiques es- } \\
\text { tan repartides equilibrada- } \\
\text { ment amb la meua parella }\end{array}$ & & & & & & \\
\hline $\begin{array}{l}\text { b) Considere que l'atenció als } \\
\text { fills/es està repartida equi- } \\
\text { libradament amb la meua } \\
\text { parella }\end{array}$ & & & & & & \\
\hline $\begin{array}{l}\text { c) Considere que repartisc de } \\
\text { forma equilibrada el temps } \\
\text { que dedique a les meues } \\
\text { necessitats personals, fami- } \\
\text { liars i laborals }\end{array}$ & & & & & & \\
\hline $\begin{array}{l}\text { d) La meua parella percep que } \\
\text { compartim les tasques do- } \\
\text { mèstiques }\end{array}$ & & & & & & \\
\hline $\begin{array}{l}\text { e) La meua parella percep que } \\
\text { compartim les responsabi- } \\
\text { litats familiars }\end{array}$ & & & & & & \\
\hline $\begin{array}{l}\text { f) Per a realitzar les tasques } \\
\text { domèstiques comptem amb } \\
\text { una persona externa }\end{array}$ & & & & & & \\
\hline $\begin{array}{l}\text { g) Per a les tasques d'atenció } \\
\text { a fills/es comptem amb una } \\
\text { persona externa }\end{array}$ & & & & & & \\
\hline
\end{tabular}

* $\quad$ CED $=$ Completament en desacord

$\mathrm{AED}=$ Un poc en desacord

$\mathrm{I}=$ Indiferent

$\mathrm{ADA}=$ Un poc d'acord

$\mathrm{CDA}=$ Completament d'acord 


\begin{tabular}{|c|c|c|c|c|c|c|}
\hline & $\mathbf{1}$ & $\mathbf{2}$ & $\mathbf{3}$ & $\mathbf{4}$ & $\mathbf{5}$ & $\mathbf{n s} / \mathbf{n c}$ \\
\hline CED & AED & I & ADA & CDA & \\
\hline $\begin{array}{c}\text { h) Per a les tasques d'atenció } \\
\text { a familiars majors o en si- } \\
\text { tuació de dependència } \\
\text { comptem amb una persona } \\
\text { externa }\end{array}$ & & & & & & \\
\hline
\end{tabular}

P25. Per a finalitzar, indiqueu quin percentatge, del $100 \%$ del vostre temps setmanal, dediqueu a:

\begin{tabular}{|l|c|c|c|}
\hline & $\begin{array}{c}\text { a) Necessitats } \\
\text { personals }\end{array}$ & $\begin{array}{c}\text { b) Necessitats } \\
\text { familiars }\end{array}$ & $\begin{array}{c}\boldsymbol{c} \text { ) Necessitats } \\
\text { laborals }\end{array}$ \\
\hline Percentatge de & $\mathrm{ns} / \mathrm{nc}$ & $\mathrm{ns} / \mathrm{nc}$ & $\mathrm{ns} / \mathrm{nc}$ \\
temps & $0 \%$ & $0 \%$ & $0 \%$ \\
& $10 \%$ & $10 \%$ & $10 \%$ \\
& $20 \%$ & $20 \%$ & $20 \%$ \\
& $30 \%$ & $30 \%$ & $30 \%$ \\
& $40 \%$ & $40 \%$ & $40 \%$ \\
& $50 \%$ & $50 \%$ & $50 \%$ \\
& $60 \%$ & $60 \%$ & $60 \%$ \\
& $70 \%$ & $70 \%$ & $70 \%$ \\
& $80 \%$ & $80 \%$ & $80 \%$ \\
& $90 \%$ & $90 \%$ & $90 \%$ \\
& $100 \%$ & $100 \%$ & $100 \%$ \\
\hline
\end{tabular}


1 De súbditos del rey a ciudadanos de la nación

2 Las órdenes militares

3 Del libro de emblemas a la ciudad simbólica

4 Economía y posguerra desde el exilio

5 Revoluciones y revolucionarios en el mundo hispano

6 La biblioteca del matemàtic Alicart

7 Los Reyes Solares

8 Las ciudades y la guerra, 1750-1898

9 La prensa local y la prensa gratuita

10 Imperios sacros, monarquías divinas

11 Fundamentalismo político y religioso

12 Radio y televisión en el ámbito local

13 La publicidad local

14 Federalismo y cuestión federal en España

15 Ceremoniales, ritos y representación del poder

16 La República participada

17 Els corcs de la Restauració. Vinaròs (1876-1923)

18 La estética de las barricadas

19 La apuesta ética en las organizaciones sanitarias

20 La comunicación local por internet

21 Conflicto y revolución en las comarcas de Castelló

22 La Cartuja de Vall de Crist en el fin del Antiguo Régimen

23 Castelló al segle XX

24 Filosofia y cultura de la tolerancia

25 Republicanisme, identitat popular i hegemonia municipal

26 Más allá de las sombras

27 Los comerciantes valencianos del siglo XV y sus libros de cuentas

28 Memoria y olvido de la historia

29 Himnos Délficos dedicados a Apolo

30 Europa: historia, imagen y mito

31 Autoritaris, catòlics i republicans

32 La otra cara de la bohemia

$33 \mathrm{El}$ precio de la derrota

34 Ideologías e intereses sociales bajo el franquismo (1939-1975)

35 José Mínguez

36 El nacimiento de la sociedad burguesa

37 Robert Boyle

38 Fent fortuna

39 Del neocatolicisme al neocarlisme

40 Investigació en Ciències Humanes i Socials

41 La fusteria a la València medieval (1238-1520)

42 La conciliación de la vida laboral y familiar en la Universitat Jaume I 

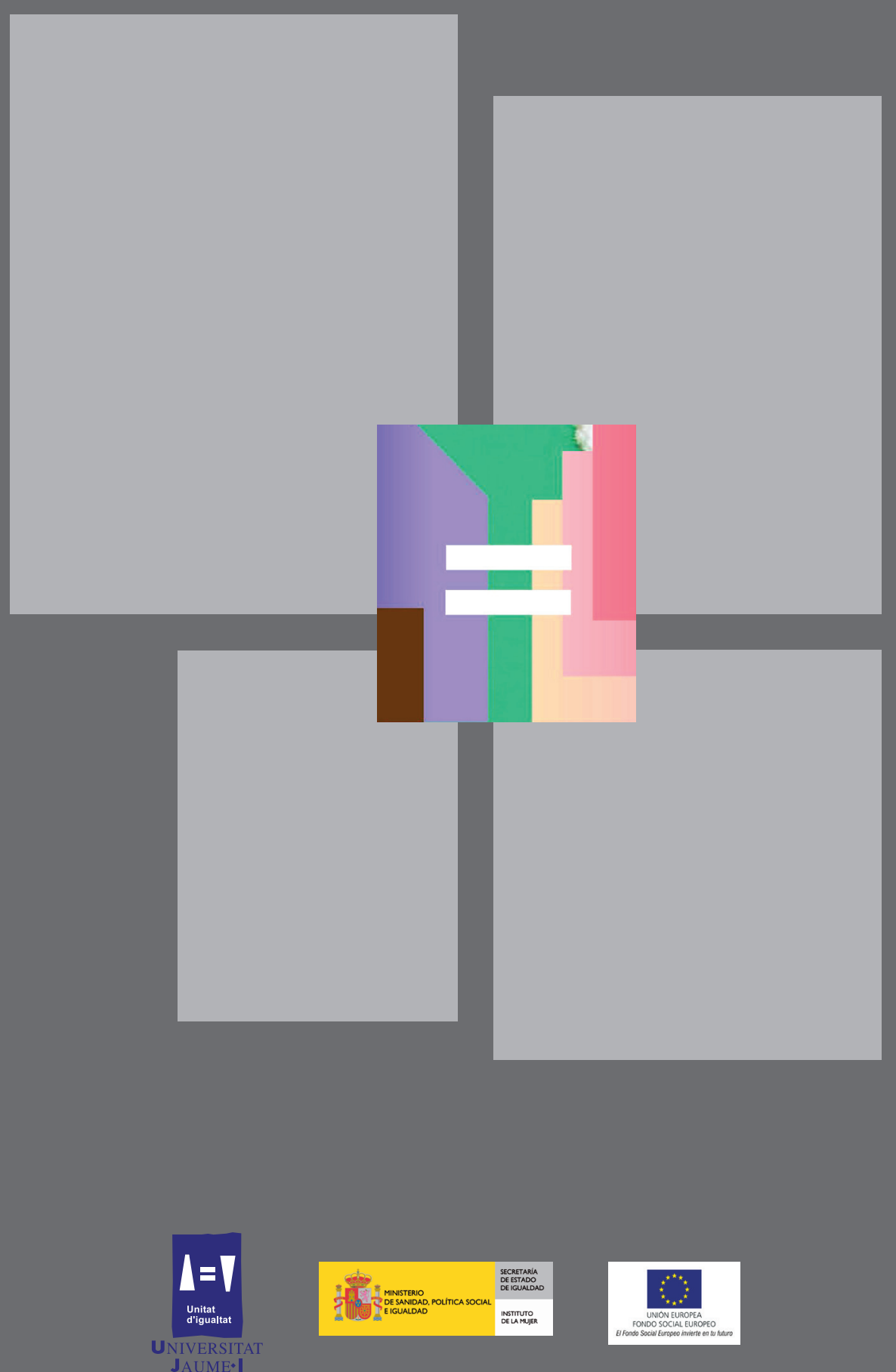

Col·lecció Humanitats Núm. 43 